\title{
Hole U1415P'
}

K.M. Gillis, J.E. Snow, A. Klaus, G. Guerin, N. Abe, N. Akizawa, G. Ceuleneer, M.J. Cheadle, Á. Adrião, K. Faak, T.J. Falloon, S.A. Friedman, M.M. Godard, Y. Harigane, A.J. Horst, T. Hoshide, B. Ildefonse, M.M. Jean, B.E. John, J.H. Koepke, S. Machi, J. Maeda, N.E. Marks, A.M. McCaig, R. Meyer, A. Morris, T. Nozaka, M. Python, A. Saha, and R.P. Wintsch²

\section{Chapter contents}

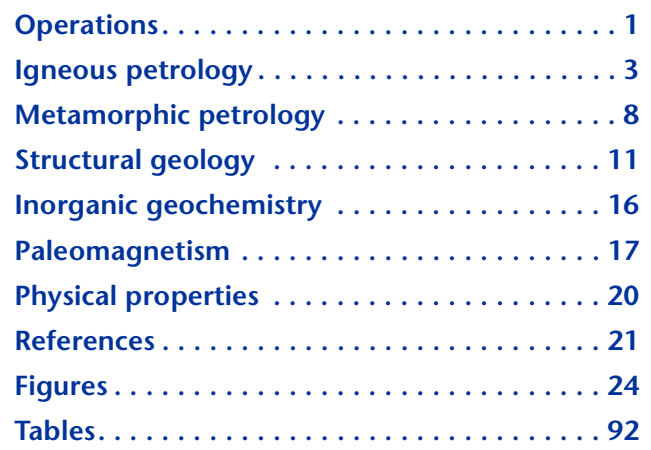

${ }^{1}$ Gillis, K.M., Snow, J.E., Klaus, A., Guerin, G., Abe, N., Akizawa, N., Ceuleneer, G., Cheadle, M.J., Adrião, Á., Faak, K., Falloon, T.J., Friedman, S.A., Godard, M.M., Harigane, Y., Horst, A.J., Hoshide, T., Ildefonse, B., Jean, M.M., John, B.E., Koepke, J.H., Machi, S., Maeda, J., Marks, N.E., McCaig, A.M., Meyer, R., Morris, A., Nozaka, T., Python, M., Saha, A., and Wintsch, R.P., 2014. Hole U1415P. In Gillis, K.M., Snow, J.E., Klaus, A., and the Expedition 345 Scientists, Proc. IODP, 345: College Station, TX (Integrated Ocean Drilling Program).

doi:10.2204/iodp.proc.345.113.2014

'Expedition 345 Scientists' addresses.

\section{Operations}

Integrated Ocean Drilling Program (IODP) Hole U1415P was sited on the southern margin of a small promontory between Holes U1415G and U1415O (see Fig. F8 in the "Expedition 345 summary" chapter [Gillis et al., 2014b]). From the outset, Hole U1415P was established as a reentry hole and was intended to be a nested free-fall funnel (FFF) configuration with casing similar to that in Hole U1415J. However, after deployment the initial FFF cone tipped over and could not be used. Instead, we were able to successfully reenter the bare hole and installed a FFF with $12.5 \mathrm{~m}$ of $10^{3 / 4}$ inch casing.

The primary accomplishment in Hole U1415P was rotary core barrel (RCB) coring that extended from 12.5 to 107.9 meters below seafloor (mbsf) and recovered $30.57 \mathrm{~m}$ of gabbroic rock $(32 \%$ recovery). In addition, material was recovered in five ghost cores obtained during hole cleaning operations in previously drilled portions of the hole. Hole operations are summarized in Table T1 and outlined below. All times are ship local time (UTC $-7 \mathrm{~h}$ ).

\section{Drilling operations}

After conducting a visual survey and selecting the position for Hole U1415P, we recovered the camera system, installed the top drive, spaced out the drill string, and started Hole U1415P at 1255 h on 26 January 2013 . The $14 \%$ inch bit was washed without rotating to 2.0 mbsf (4866.0 meters below rig floor [mbrf]), and drilling proceeded to $11.0 \mathrm{mbsf}$ ( $4875.0 \mathrm{mbrf}$ ). We then assembled a hard rock recovery system-style FFF cone. The 26 inch interior diameter of this cone was reduced to 16 inches by attaching portions of a CORK fishing tool funnel. In contrast to our previous FFF cone deployments, this time we attached a base plate to the bottom of the FFF. After the FFF cone was deployed to the seafloor, we continued drilling the hole to $12.5 \mathrm{mbsf}$. The camera was deployed to observe the orientation of the FFF cone and the bit pulling out of it. However, the FFF was very difficult to see through clouds of sediment. Eventually, we decided not to wait and pulled the bit out of the hole and through the FFF cone at $1545 \mathrm{~h}$ on 27 January. The bit appeared to heave down on the cone at least twice in the process. The bit was back on the rig floor at $0105 \mathrm{~h}$ on 28 January. We assembled $12.5 \mathrm{~m}$ of $103 / 4$ inch casing and hung it off on the moonpool doors. Next, we assembled a RCB bottom-hole assembly (BHA) and lowered it through the cas- 
ing in the moonpool to the seafloor. The camera system was also deployed to the seafloor. Before we prepared to locate and reenter Hole U1415P, we had to slip and cut the drill line for the fourth time during this expedition. After installing the top drive and spacing out for reentry, it was immediately apparent that the FFF cone was not sitting upright. Some camera perspectives looked as if the FFF cone was leaning to one side, whereas in other perspectives it appeared to be lying fully on its side. At the base of the FFF cone was a dark spot that appeared to be the top of the hole. Discussions alternated between attempting to reenter the cone or the hole. Eventually the pipe was maneuvered close enough to take a stab at cone reentry. The cone was indeed lying on its side at too high an angle for reentry, and this attempt failed. We then moved the bit over the dark area at the base of the FFF cone and successfully reentered Hole U1415P at $1450 \mathrm{~h}$ on 28 January. The total time expended after starting to search for the FFF cone was $2.6 \mathrm{~h}$. The reentry of the bit into the open $14 \%$ inch hole with $>4800 \mathrm{~m}$ (3.0 miles) of drill string deployed was quite an impressive feat achieved by the dynamic positioning system and drilling staff. The camera system was recovered, and the hole was redrilled from 8.0 to $12.5 \mathrm{mbsf}$ and swept with high-viscosity mud. The core barrel used during washing and reaming this interval (Core 345-U1415P-2G) was recovered with $2.36 \mathrm{~m}$ of rubble. Our next step was to assemble a FFF cone to the $12.5 \mathrm{~m}$ of $103 / 4$ inch casing hung off in the moonpool. We free-fall deployed the $103 / 4$ inch casing with the attached FFF and dropped a core barrel to start coring ahead. The driller could not identify the normal pressure spike that occurs when the core barrel has landed at the bottom of the BHA. When the pump pressure was increased to confirm the core barrel had landed properly, the rotary hose that supplies drilling fluid to the top drive suddenly burst. The hose failed on the top drive connection at $2400 \mathrm{psi}$ even though the hose is rated to 5000 psi working pressure. After we installed a new hose, we reached the bottom of the hole (12.5 mbsf) at $0500 \mathrm{~h}$ on 29 January. We started RCB coring, and Core 3R (12.5-18.1 mbsf) arrived on deck at $1225 \mathrm{~h}$. We had some difficulty getting the bit through the depth where the hole diameter changed from $143 / 4$ inch to $9 \% 8$ inch, but we were able to drill out this area (Core 4G; 12.5-16.5 mbsf). RCB coring resumed, and Cores 5R-10R extended the hole from 18.1 to $45.6 \mathrm{mbsf}$ and recovered $12.19 \mathrm{~m}$ (44\% recovery) of nicely cored pieces of gabbro. Core $11 \mathrm{R}$ was cut in only $45 \mathrm{~min}$ of rotating time. RCB coring continued to Core 18R, extending to $82.3 \mathrm{mbsf}$ and recovered on deck at 0920 on 1 February. As the hole was deepened, we experienced faster coring rates through a formation inferred to be more fractured, leading to increasingly difficult hole cleaning. Eventually, we decided to pull out of the hole for a bit change because of increasing bit hours, decreasing recovery, and extended periods of washing/reaming back to bottom after recovering core barrels. We pulled the bit out of the hole, and the bit was back on the rig floor at $1845 \mathrm{~h}$ on 1 February. After assembling a new C-7 RCB bit, we lowered the drill string, deployed the camera system, installed the top drive, and spaced out the drill string for reentry by $0530 \mathrm{~h}$ on 2 February. We reentered Hole U1415P at $0553 \mathrm{~h}$ on 2 February. During reentry, we confirmed the top of the FFF cone was at 4862.5 mbrf. The height of the FFF from base plate to rim is $1.2 \mathrm{~m}$, placing the base of the FFF at 4863.7 mbrf. The seafloor tag depth was determined to be 4864.0 mbrf on 26 January at slack tide. The FFF depth was established on 2 February when the tide tables indicated a high tide of $0.2 \mathrm{~m}$. Therefore, the FFF appears to be installed right at the seafloor ( $4863.9 \mathrm{~m}$ versus $4864.0 \mathrm{~m}$ ).

We washed and reamed to the bottom of the hole (82.3 mbsf) slowly to clean out the hole in small increments as opposed to loading up the annulus with large amounts of fill/cuttings and then having to wash these out all at once. After we finished washing and reaming to the bottom of the hole $(82.3 \mathrm{mbsf})$, we recovered the core barrel used during this hole cleaning (Core 19G; $0.6 \mathrm{~m}$ recovered) at $1920 \mathrm{~h}$. We resumed RCB coring, and Core 20R was cut from 82.3 to 89.4 mbsf. Before retrieving Core 20R, the hole had to be washed and cleaned enough to attempt making a connection. At the time, several bit nozzles also appeared to be plugged. At $0030 \mathrm{~h}$ on 3 February, we were able to remove a drilling knobby so that Core $20 \mathrm{R}$ could be recovered $(0130 \mathrm{~h})$ with $2.42 \mathrm{~m}$ of nicely cored gabbro. A new core barrel was deployed, and the drillers were able to partially unplug the bit nozzles. Before coring could resume, the hole had to be washed and reamed from 79.0 to 89.4 mbsf. At $0900 \mathrm{~h}$, the core barrel deployed during this reaming was retrieved (Core $21 \mathrm{G}$ ). We had to wash and ream back to the bottom of the hole again but then continued coring from there. Cores 22R and 23R were recovered from 89.4 to $107.9 \mathrm{mbsf}$ and recovered $4.87 \mathrm{~m}$ (26\% recovery). After retrieving Core 23R, hole conditions began deteriorating, with the hole packing off and the bit taking weight $\sim 9 \mathrm{~m}$ above the bottom of the hole. As we had just added a joint of pipe and the bit was unable to pass below this depth, we had to offset the ship $100 \mathrm{~m}$ to reach a connection so that the driller could pull up and lay out the same piece of pipe. At this point, we raised the bit to $76.0 \mathrm{mbsf}$, resumed hole cleaning, reamed back to the bottom of the hole (107.9 mbsf), and re- 
covered the core barrel used during the reaming (Core 24G). Once again, the hole packed off and circulation and rotation were lost while making the connection after laying out the barrel, so we offset the ship $100 \mathrm{~m}$ ( $2 \%$ of water depth) to reach a connection in order to remove more drill pipe. We raised the bit to $79.0 \mathrm{mbsf}$ and started to work the bit back down. However, after making another connection the bit could not be advanced further because of high torque, packing-off, and plugged nozzles. Ultimately, we decided to stop trying to core and to conduct a wiper trip to prepare the hole for logging.

To prepare for logging, we raised the bit to $11.9 \mathrm{mbsf}$ (inside the 103/4 inch casing) and then lowered it back down the hole. Problems were encountered at $41,55-60$, and $84-90$ mbsf that had to be drilled through. We elected not to attempt to clean out the $\sim 18 \mathrm{~m}$ of hard fill in the bottom of the hole. At 1215 $\mathrm{h}$ on 4 February, the bit was back up to $11.9 \mathrm{mbsf}$ (inside the casing). We deployed the camera and pulled the bit clear of the hole at $1434 \mathrm{~h}$. At $1449 \mathrm{~h}$ on 4 February, we observed the bit successfully release from the BHA. The end of pipe reentered Hole $\mathrm{U} 1415 \mathrm{P}$ at $1550 \mathrm{~h}$ after only $15 \mathrm{~min}$ of maneuvering. We recovered the camera, placed the end of pipe at $10 \mathrm{mbsf}$, and lowered the first logging string into the hole (caliper and Dipole Sonic Imager). We had decided to deploy a very short logging string because of the poor hole conditions and risk of the tools getting stuck. The logging tool string could not pass $24 \mathrm{mbsf}$ ( $11.5 \mathrm{~m}$ below the $103 / 4$ inch casing shoe). The logging tools were retrieved so that the end of pipe could be lowered past the trouble area. However, the end of the drill pipe could not be lowered past 20 mbsf (7.5 $\mathrm{m}$ below the casing shoe), so we terminated our logging. We pulled the bit out of the hole at $0315 \mathrm{~h}$ on 5 February. RCB coring in Hole U1415P extended from 12.5 to $107.9 \mathrm{mbsf}$ and recovered $30.57 \mathrm{~m}$ (32\% recovery) of gabbroic rock. In addition, five cores were recovered from previously drilled portions of the hole during the hole cleaning operations.

Because there was not sufficient time remaining to conduct any further drilling operations, as we had dropped the bit for logging, we deployed the camera and $3.5 \mathrm{kHz}$ pinger to conduct a final seafloor survey across Hole U1415P (see Table T1 and Fig. F3 in the "Bench site survey" chapter [Gillis et al., 2014a]). The survey was completed at $0845 \mathrm{~h}$ on 5 February. Although the drill string was back on board at 1745 $\mathrm{h}$, the beacon retrieved at $1838 \mathrm{~h}$, and the hydrophones raised by $1900 \mathrm{~h}$ on 5 February, we delayed our departure until $2000 \mathrm{~h}$ on 5 February so that inductively coupled plasma-atomic emission spectroscopy geochemical analyses that are sensitive to ship motion could be completed. After we raised the thrusters, we started our transit to Balboa, Panama, at $2048 \mathrm{~h}$, about a half day ahead of the scheduled departure time. During the transit, ship local time was shifted ahead $1 \mathrm{~h}$ on 7 February (to UTC -6 ) and $1 \mathrm{~h}$ on 9 February (to UTC -5 ). The $\sim 1467 \mathrm{nmi}$ transit from Hess Deep to Balboa took 6.5 days at 9.3 $\mathrm{nmi} / \mathrm{h}$. Expedition 345 ended with the first line ashore at $1151 \mathrm{~h}$ on 12 February 2013.

\section{Igneous petrology}

Drilling in Hole U1415P recovered 31 lithologic intervals in RCB cores and 39 intervals in ghost cores. Table T2 lists these lithologic intervals and their division into three units. Principal lithologies recovered from Hole U1415P are shown in Figure F1. Analyses of cored gabbroic rock in Hole U1415P (olivine gabbro, orthopyroxene-bearing olivine gabbro, and troctolite) revealed primitive compositions with $\mathrm{Mg \#}$ $(100 \times$ cationic $\mathrm{Mg} /[\mathrm{Mg}+\mathrm{Fe}]$ with all Fe recalculated as $\mathrm{Fe}^{2+}$ ) varying between 78.3 and 88.6 (see "Inorganic geochemistry"). The uppermost core recovered during hole cleaning (Core 345-U1415P-2G) consists of very fine grained to coarse-grained sand with basaltic and gabbroic rubble and is defined as lithologic Unit I.

Unit II, the Multitextured Layered Gabbro Series, is composed of olivine gabbro and orthopyroxenebearing olivine gabbro that show a remarkably wide spectrum of textural variety, including a spectacular banded series, layering features, noritic bands, diffuse interfingering of modal and texturally different lithologies, skeletal olivines, and pegmatitic growth. A characteristic feature of this series is the omnipresence of late-crystallized clinopyroxene that may occur interstitially as films or ribbons on the grain boundaries of the rock matrix, forming centimetersized coherent anhedral crystals growing across lithologic boundaries. In pegmatitic patches, clinopyroxene sometimes forms discrete crystals with grain sizes as large as $\sim 8 \mathrm{~cm}$. Detailed descriptions of these rocks are presented below.

Below Piece 6 in Core 345-U1415P-15R-1, the lithologic character changes abruptly from heterogeneous, multitextured gabbro to homogeneous, medium- to coarse-grained granular troctolite (with small amounts of olivine gabbro), which is defined as Unit III, the Troctolite Series. Below, we present macroscopic and, where available, microscopic descriptions for the rocks recovered in Hole U1415P, including the interval numbers from which these rocks were recovered. For some thin sections in Hole U1415P, two different lithologic domains were defined. Table T3 lists the corresponding thin sections, 
the number and nature of the individual domains, the characteristics of the boundaries between the domains, and a link for the corresponding image of the thin section with the domain boundaries marked.

\section{Unit I: basaltic/gabbroic rubble}

Examples of recovered igneous rock from this unit are a medium-grained, granular to poikilitic olivine gabbro (Interval G6), a coarse-grained granular to poikilitic orthopyroxene-bearing olivine gabbro (Interval G7), and a sparsely phyric basalt (Interval G8). The basalt piece is moderately altered and contains $<1 \%$ phenocrysts of euhedral to subhedral olivine, subhedral to anhedral plagioclase, and euhedral clinopyroxene.

\section{Unit II: Multitextured Layered Gabbro Series}

\section{Olivine gabbro}

Multitextured olivine gabbro forms the dominant lithologic interval recovered from Unit II in Hole $\mathrm{U} 1415 \mathrm{P}$ and is the defining lithology of the series. However, thinner intervals of relatively more homogeneous equigranular olivine gabbro also occur throughout Cores 345-U1415P-6R through 13R (Fig. F1). Magmatic foliation is generally weak; layering or a characteristic banding is common (for details see "Structural geology").

The multitextured olivine gabbro displays complex variation in both modal proportions of minerals grain size and mineral habit (Fig. F2) and consists of olivine (5\%-30\%), plagioclase $(50 \%-70 \%)$, and clinopyroxene $(5 \%-40 \%)$, with trace amounts of orthopyroxene and oxide (Cr-spinel, often altered to magnetite). Olivine is subhedral to anhedral with an amoeboid habit. Tabular plagioclase is euhedral to subhedral. Clinopyroxene is anhedral and dominantly subequant, forming large $(40 \mathrm{~mm})$ poikilitic grains.

\section{Orthopyroxene-bearing olivine gabbro}

Orthopyroxene-bearing olivine gabbro occurs as a major lithologic interval in the Unit II Multitextured Layered Gabbro Series. Orthopyroxene-bearing olivine gabbro appears either as a more homogeneous equigranular gabbro, which is the dominant lithology in the upper part of Unit II (Cores 345-U1415P$5 \mathrm{R}$ through $7 \mathrm{R}$ ), or as domains within the dominantly multitextured gabbro in the lower part of Unit II (e.g., Intervals 4 and 8 in Fig. F3 and Interval 21 in Fig. F4). Multitextured orthopyroxene-bearing olivine gabbro is also a major lithology, along with the dominant multitextured olivine gabbro in the lower part of Unit II (Cores 345-U1415P-8R through $12 \mathrm{R})$. In general, orthopyroxene-bearing gabbro consists of olivine $(15 \%-20 \%)$, plagioclase $(50 \%-70 \%)$, clinopyroxene (15\%-30\%), orthopyroxene (1\%-4\%), and trace amounts of oxide (Cr-spinel, often altered to magnetite). Olivine is subhedral to anhedral with an amoeboid habit. Plagioclase is euhedral to subhedral with a tabular habit. Clinopyroxene is anhedral, forming large interstitial grains. Orthopyroxene is anhedral, forming smaller interstitial grains. Coexisting clinopyroxenes and orthopyroxenes are common without any visible reaction between these two minerals.

\section{Olivine-bearing gabbro}

Olivine-bearing gabbro occurs in two ghost core intervals (Intervals G9 and G10) of Unit II. The gabbro is coarse-grained seriate poikilitic granular rock. The primary mineralogy is olivine (1\%), plagioclase (65\%), and clinopyroxene (34\%). Olivine is subhedral to anhedral with an amoeboid habit. Plagioclase is subhedral to anhedral with a tabular habit. Clinopyroxene is anhedral and poikilitic with a subequant habit and contains plagioclase chadacrysts.

\section{Unit III: Troctolite Series}

Troctolite is the major lithology in both cores (Intervals 29 and 31) and ghost cores (Intervals G29 - G32, G33 - G37, G39) of the Unit III Troctolite Series (Fig. F1). Magmatic foliation defined by tabular plagioclase and prismatic olivine is common (for details see "Structural geology"). In contrast to the extreme variability in textures displayed by the Unit II Multitextured Layered Gabbro Series, troctolite shows a remarkable degree of homogeneity in both modal composition and grain size (Figs. F2, F5, F6). Troctolite generally consists of olivine (30-54 vol\%) and plagioclase (45-70 vol\%), with trace amounts of clinopyroxene $(<1 \%)$ and oxide $(<1 \% \mathrm{Cr}$-spinel). Olivine is euhedral to subhedral with a subequant habit. Although olivine in Unit II often shows skeletal textures (see section below), it is generally prismatic in Unit III. Plagioclase is subhedral to anhedral with a tabular habit. Clinopyroxene is anhedral with an interstitial habit. Interstitial clinopyroxene in many cases is optically continuous, forming what appears to be large coherent grains with grain sizes often $>20 \mathrm{~mm}$. For example, interstitial clinopyroxene in Figure F6 is formed by two large, centimetersized clinopyroxene grains. 


\section{Macroscopic characterization of multitextured olivine gabbro}

In the multitextured orthopyroxene-bearing olivine gabbro of Unit II, large variations in modal composition and grain size of the constituent minerals and in textural appearance are observed. Based on their macroscopic features, the rocks of this unit have been classified into five lithologic groups:

1. Homogeneous medium-grained orthopyroxenebearing olivine gabbro: the mineral assemblage of this rock type is plagioclase + olivine + clinopyroxene + orthopyroxene, which is the dominant lithology in Unit II. The rocks are homogeneous, granular, and medium grained.

2. Orthopyroxene-bearing pegmatitic olivine gabbro: this mineral assemblage is the same as for the first group (plagioclase + olivine + clinopyroxene + orthopyroxene), but these rocks show much more variation in texture, which is the reason for assigning them to the second lithologic group. The textures are inequigranular granular and in general have a much coarser grain size, as coarse as pegmatitic. These rocks include enclave-like patches of homogeneous, medium-grained orthopyroxene-bearing olivine gabbro (Fig. F7). One characteristic feature of the rocks within this group is the presence of skeletal olivine (see "Skeletal olivine in Unit II").

3. Pegmatoidal veins: this rock type, which is less common in Unit II, has a plagioclase + olivine + clinopyroxene + orthopyroxene mineral assemblage. A characteristic feature is veins of pegmatitic orthopyroxene-bearing olivine gabbro that interfinger with the homogeneous mediumgrained orthopyroxene-bearing olivine gabbro of Group 1 (Figs. F8, F9). The boundaries between the pegmatitic veins and the Group 1 gabbros are sutured. Greenish pegmatitic clinopyroxene (several centimeters in size) occurs in a vein within Sample 345-U1415P-4G-1, 62$93.5 \mathrm{~cm}$ (Piece 8) (see the upper right part of the piece shown in Fig. F9A). In this vein, plagioclase grows perpendicular to the vein wall in a typical comb-structure mode. The outer part of the pegmatitic vein is composed of plagioclase, whereas both orthopyroxene and clinopyroxene occur only in the inner part. Skeletal olivine is also observed in this rock (see the lower part of pieces in Fig. F9).

4. Heterogeneous olivine gabbro: the mineral assemblage of this group is plagioclase + olivine + clinopyroxene + orthopyroxene and defines a markedly heterogeneous lithology, character- ized by the presence of elongated monomineralic domains that often display layering or banding or are disrupted to elongated aggregates, often with parallel alignment of the minerals (Fig. F10). Large plagioclase-rich domains are aggregates of fine-grained plagioclase crystals (average size $=0.3 \mathrm{~mm}$ ). Often, clusters of isometric euhedral to subhedral spinel crystals occur in the plagioclase-rich domains. The pale greenish smoky part is composed of fine-grained plagioclase and poikilitic clinopyroxene. Skeletal olivine is also present.

5. Vertical bands: these rocks (plagioclase + olivine + clinopyroxene + orthopyroxene mineral assemblage) show spectacular subvertically oriented $\sim 5 \mathrm{~cm}$ thick bands (Fig. F11) that may possibly be interpreted as subvertical "intrusions" (or banded layers) into heterogeneous olivine gabbro or as originally horizontal nonplanar layers now rotated into a subvertical position. Within the layer at the boundary to the host rock (heterogeneous olivine gabbro; Group 4), subvertically elongated monomineralic domains of constituent minerals (olivine, plagioclase, and clinopyroxene) can be observed. The subvertical bands are composed of two outermost plagioclase-rich layers $(\sim 5-10$ $\mathrm{mm}$ thick) followed by an inner band of olivine gabbro composed of plagioclase, olivine, clinopyroxene, and orthopyroxene ( $40 \mathrm{~mm}$ thick). In the outermost plagioclase-rich layers, the longer axes of plagioclase grains are arranged perpendicular to the boundary with the host rock. The gabbroic band shows characteristic asymmetrical olivine distribution. As shown Figure F11, at one side of the subvertical band a thin layer of dominantly fine grained equant olivine is observed. From here, the grain size of olivine increases toward the center of the band, and its shape changes from an equant to a more skeletal form. The boundary between plagioclase-rich and olivine-rich layers at one side is straight, and the boundary between the plagioclase-rich layer and the surrounding host gabbro is wavy. In contrast, the boundary between plagioclaserich and olivine-rich layers at the other side is wavy and the boundary between the plagioclase-rich layer and the host gabbro is straight.

\section{Descriptions of igneous boundaries}

Within the Multitextured Layered Gabbro Series (lithologic Unit II) and the Troctolite Series (Unit III), four samples with igneous boundaries were recovered in Hole U1415P. The available thin sections of these boundaries enable microscopic characteriza- 
tion of the two igneous lithologies, which are differentiated by changes in mode and/or grain size (Table T4). The first two boundaries are within the Multitextured Layered Gabbro Series (Unit II), defining the boundary between relatively coarse grained olivine gabbro host rock that bears diffuse patches interpreted as enclaves of more finely grained mafic orthopyroxene-bearing olivine gabbro (Figs. F12, F13). The two other examples illustrate boundaries in the Troctolite Series (Unit III) between medium-grained troctolite and a finer grained dark-colored olivine gabbro, one of which is orthopyroxene bearing (Figs. F14, F15).

\section{Interval 13 (Thin Section 114)}

The boundary in Sample 345-U1415P-7R-2, 9.5-56 $\mathrm{cm}$ (Piece 2), is defined as a grain size and modal boundary (Fig. F12). The modal composition is slightly different between the orthopyroxene-bearing troctolite domain and the olivine gabbro host rock, described as an "anorthosite domain" because the corresponding thin section contains only plagioclase because of the heterogeneous distribution of large minerals (or mineral aggregates). The grain size of the anorthosite domain is slightly coarser than the orthopyroxene-bearing troctolite domain. The boundary is sutured, and the minerals are continuous through the boundary. Macroscopic and microscopic observations are consistent with a model of diffuse intermingling of two types of coherent magma batches under hypersolidus condition. The finer grained orthopyroxene-bearing troctolite domain could alternatively be interpreted as some kind of "enclave" hosted by the coarser grained olivine gabbro (see "Enclaves and magma mixing").

\section{Interval 27 (Thin Section 127)}

The boundary in Sample 345-U1415P-14R-1, 16-25.5 $\mathrm{cm}$ (Piece 3 ), is defined as a grain size and modal boundary that is sutured (Fig. F13). The modal composition is different between the orthopyroxenebearing olivine gabbro domain and the gabbro domain. Based on thin section observation, the grain size of the orthopyroxene-bearing olivine gabbro domain is coarser than that of the gabbro domain, although macroscopic observation suggests large plagioclase grain sizes. However, thin section observations imply that these larger grains are "anorthositic" aggregates of much finer plagioclases, now well equilibrated to a granoblastic mosaic-like texture, which implies an annealing stage resulting in recrystallization of the coarse primary plagioclase grains to a fine-grained network. As in the previous sample, this boundary may be either interpreted as a frozen boundary between two types of coherent magma batches intermingling with each other under hypersolidus conditions or as an enclave of orthopyroxene-bearing olivine gabbro in the more heterogeneous olivine gabbro.

\section{Interval 29 (Thin Section 134)}

The boundary in Sample 345-U1415P-18R-1, 78-83.5 $\mathrm{cm}$ (Piece 7), is defined as a grain size and modal boundary that is sutured (Fig. F14). The modal composition is different between the anorthositic troctolite domain and the orthopyroxene-bearing olivine gabbro domain. The grain size of the anorthositic troctolite domain is coarser than that of the orthopyroxene-bearing olivine gabbro domain. Minerals are continuous across the boundary. Because of the strong alteration observed in this sample, detailed microscopic characterization is hampered. Based on macroscopic observation, this boundary was interpreted as intrusive (see "Structural geology").

\section{Interval 29/30 boundary (Thin Section 140)}

The boundary in Sample 345-U1415P-22R-2, 99$115.5 \mathrm{~cm}$ (Piece 8), is defined as a grain size and modal boundary that is sutured (Fig. F15). The modal composition is different between the troctolite domain and the olivine gabbro domain. The grain size of the troctolite domain is coarser than that of the olivine gabbro domain. Plagioclase in the finer grained olivine gabbro defines strong foliation parallel to the boundary. This, together with macroscopic observation, implies an intrusive boundary of the finer grained olivine gabbro into the troctolite.

\section{Downhole variations of mode and grain size within Units II and III}

Rock in Hole U1415P shows variations in mineral modal abundances, average mineral size, and maximum grain size as a function of depth (Fig. F2). These variations are also a function of rock type. A major change in lithologic features in this hole is the boundary between Units II and III, and the mineral modes correspond with this lithology contrast.

\section{Olivine}

Olivine occurs in both units. In Unit II, olivine has a modal amount of $\sim 20 \%$ but increases in Unit III to $\sim 35 \%$, on average. This change in modal composition is not reflected in the maximum size or size mode of olivine in the two units. In Unit II, olivine has a heterogeneous grain size distribution, varying from as large as $14 \mathrm{~mm}$ in Core $345-\mathrm{U} 1415 \mathrm{P}-7 \mathrm{R}$ (where skeletal olivines are observed) to as small as 2 $\mathrm{mm}$. The average, however, is weighted to $\sim 10 \mathrm{~mm}$ 
because of the occurrence of skeletal/dendritic olivines throughout this unit.

In Unit III, the modal composition, size mode, and maximum size display a homogeneous distribution. Modal abundance ranges from 30\% to 54\% (average $=\sim 35 \%$ ), with a size mode of $\sim 4 \mathrm{~mm}$ and maximum size of $10 \mathrm{~mm}$. The abrupt change in the olivine mode and maximum size to low values in Core 345U1415P-22R (Fig. F2) corresponds to the boundary between olivine gabbro and troctolite (Intervals 29 and 30, respectively). This boundary is interpreted as an intrusion of olivine gabbro into troctolite (see "Structural geology").

\section{Plagioclase}

The multitextured nature of Unit II is reflected in the variable maximum grain size of plagioclase. Grain size is very heterogeneous, whereas the modal abundance of the plagioclase is relatively homogeneous (50\%-70\%). Plagioclase grain size varies from 2 to 10 $\mathrm{mm}$ in this unit (Fig. F2). At the Unit II/III boundary, plagioclase grain size is more homogeneous and averages $\sim 10 \mathrm{~mm}$. The modal amount of plagioclase in the Troctolite Series varies between $45 \%$ and $79 \%$. The Troctolite Series is composed of only two troctolite intervals that span tens of meters. A marked change in plagioclase grain size is associated with the olivine gabbro/troctolite boundary recovered in Core 345-U1415P-22R.

\section{Clinopyroxene}

Modal abundance for clinopyroxene ranges from $\sim 20 \%$ to $30 \%$ in Unit II (Multitextured Layered Gabbro Series), with grains as large as $60 \mathrm{~mm}$ (Core 345U1415-5R; Fig. F2), the largest clinopyroxene grains observed in Hole U1415P. Below Core 5R, clinopyroxene reaches a maximum size of $50 \mathrm{~mm}$, with an average of $\sim 30 \mathrm{~mm}$. A sharp change in clinopyroxene mode and grain size occurs at 64.2 mbsf (i.e., the boundary between the Multitextured Layered Gabbro Series [Unit II] and the equigranular Troctolite Series [Unit III]). Clinopyroxene is rare or absent in the Troctolite Series, in which it is observed macroscopically as an interstitial phase, and is generally $<1$ $\mathrm{mm}$.

In addition to the phases described above, the occurrence of orthopyroxene and oxides (chromite/magnetite) also changes with depth and rock type. In Unit II, the modal amount of oxide varies between trace and 1\%; in Unit III the oxide mode varies between trace and $0.8 \%$. Orthopyroxene is only observed in Unit II and locally makes up as much as 5\% of the modal composition; it is not observed in Unit III except for a small orthopyroxene-bearing olivine gabbro patch in Sample 345-U1415P-18R-1, 78-83.5 $\mathrm{cm}$ (Piece 7) (Fig. F14). The maximum size of observed orthopyroxene is $40 \mathrm{~mm}$ (Core 345-U1415P$4 G)$.

\section{Skeletal olivine in Unit II}

Similar to the skeletal olivine interval at the top of Unit III (Troctolite Series) in Hole U1415J, olivine in Hole U1415P displays a skeletal morphology. The skeletal olivine in Hole U1415P is part of Unit II (Multitextured Layered Gabbro Series). However, unlike Hole U1415J where skeletal olivine occurs for $\sim 15 \mathrm{~m}$, skeletal olivine in Hole U1415P occurs within a $\sim 50 \mathrm{~m}$ interval that makes up the bulk of the stratigraphy of Unit II. Skeletal olivine is generally interpreted as a disequilibrium cooling phenomenon and grows normal to the cooling surface along a thermal gradient (Donaldson, 1976).

Figure F16 shows various olivine morphologies and occurrences observed in Hole U1415P, which include

- A $\sim 21 \mathrm{~cm}$ section filled solely with skeletal olivine (Sample 345-U1415P-7R-2, 9.5-30 cm [Piece 2]) (Fig. F16B). The bottom of this section hosts a rectangular patch of orthopyroxene-bearing olivine gabbro interpreted as an enclave (Fig. F7);

- Skeletal olivine that shows very elongated, subvertically orientated structures ("channel-like") anastomosing with the host rock (Sample 345U1415P-8R-1, 133-146 cm [Piece 9]) (Fig. F16C). This interval in particular occurs beneath the part with the marked banded feature, suggestive of magma mingling;

- A $~ 25 \mathrm{~mm}$ long poikilitic olivine grain with orthopyroxene chadacrysts (Sample 345U1415P-9R-1, 29-42 cm [Piece 3]) (Fig. F16D). This centimeter-sized olivine oikocryst occurs at the boundary of a centimeter-sized poikilitic clinopyroxene. In the next section downhole, another centimeter-sized olivine was observed;

- A $30 \mathrm{~mm}$ diameter dendritic (or star burst) olivine (Sample 345-U1415P-10R-1, 55.8-68 cm [Piece 7]) (Fig. F16E); and

- An olivine "bud" that crosscuts a plagioclaserich vein and branches out. The "stalks" on these branches are end-capped by equigranular $6 \mathrm{~mm}$ olivine grains. Interstitial to the olivine dendrites is centimeter-sized interstitial clinopyroxene (Sample 345-U1415P-13R-2, 40-50 cm [Piece 5]) (Fig. F16H).

The images in Figure F16 are only a small sampling of the skeletal textures within Unit II. Complete sections within Unit II of Hole U1415P are entirely skeletal. 


\section{Metamorphic petrology}

\section{Background alteration}

Surficial rubble Unit I contains a variety of discontinuous rocks (Intervals G6-G8) as well as a section of sand and gabbroic rubble (Intervals G1-G5 in Core 345-U1415P-2G). Multitextured Layered Gabbro Series Unit II exhibits pervasive background alteration with variable intensity ranging from $<10 \%$ to $90 \%$, with no apparent trend downhole (Fig. F17). Troctolite Series Unit III exhibits pervasive background alteration of variable intensity and is typically moderately altered (30\%-60\%) but locally ranges to completely altered ( $>90 \%)$.

Intense alteration is associated with cataclastic zones, igneous contacts, and hydrothermal veins. Mineral assemblages defining distinct metamorphic zones are absent, and alteration does not appear to correlate with igneous grain size. Most secondary minerals are visible to the naked eye. However, for the identification of some minerals, particularly finegrained minerals, optical petrography was required. A summary of alteration observed in thin section in presented in Tables T5 and T6. Thin sections with two or more metamorphic domains are listed in Table T7. A summary of X-ray diffraction (XRD) results for vein-filing materials and cataclasites is presented in Table T8.

\section{Olivine}

The intensity of olivine alteration is highly variable (10\%-100\%; Fig. F17). On average, it is slightly more altered in Unit III than Unit II (Table T5). The complicated igneous structure of this unit contributes to the variation of alteration intensity because alteration minerals are abundant at contacts between different lithologies (Fig. F18). Microscopic fracturing and veining are common and likely give rise to a local increase of alteration intensity. Olivine is more highly altered in the troctolite of Unit III han in the Multitextured Layered Gabbro Series of Unit II (70\%$100 \%$ replacement based on thin section observations). Serpentinization and clay mineral formation after olivine are common throughout the hole but dominant in Unit III compared to Units I and II (Fig. F19). The formation of coronitic tremolite and chlorite is common in Unit II but rare or very localized in Unit III. For example, in an anorthosite dikelet (Interval 31; Section 345-U1415P-23R-1 [Piece 2]) and also in intensely altered intervals that contain clinozoisite, chlorite with a minor amount of acicular amphibole forms pseudomorphs after olivine (possibly vein halos; e.g., Interval 29; Section 345-U1415P22R-1 [Piece 8]).
Coronitic tremolite and chlorite are found primarily in Unit II in Hole U1415P, and the coronitic zonal structure is less well developed than in Hole U1415J (Fig. F20; see also the "Hole U1415J" chapter [Gillis et al., 2014e]).

Serpentinization of olivine forms a mesh texture and commonly produces the mineral assemblage of serpentine + magnetite \pm sulfides. Clay mineral pseudomorphs after olivine are common in Hole U1415P and the other Site U1415 holes. Where these clay mineral pseudomorphs are clearly observed, crosscutting relationships suggest a temporal sequence of sheet-silicate formation replacing olivine of, from older to younger, talc, serpentine, and clay minerals (Fig. F21). Radial cracks in plagioclase, commonly filled with prehnite or chlorite, adjacent to serpentinized olivine are also common characteristics of other primitive oceanic gabbro (Blackman, Ildefonse, John, Ohara, Miller, MacLeod, and the Expedition 304/305 Scientists, 2006; see also the "Hole U1415J" chapter [Gillis et al., 2014e]). Where olivine in troctolite is intensely serpentinized, plagioclase appears to be completely altered to prehnite + chlorite \pm garnet (or possibly hydrogrossular) (Fig. F22).

\section{Pyroxene}

Clinopyroxene is variably altered (5\%-70\%) in all units of Hole U1415P and displays no variation in intensity downhole (Fig. F17). Clinopyroxene is primarily altered to green or colorless amphibole and lesser amounts of chlorite along fractures and cleavage surfaces (Fig. F23). In several intervals of Unit III, secondary clinopyroxene occurs adjacent to amphibole patches in primary clinopyroxene (Fig. F24). In highly altered troctolite, clinopyroxene is serpentinized and shows a bastite-like texture (Fig. F25).

Orthopyroxene is a minor magmatic phase in Unit II and is variably altered (5\%-90\%) to colorless or pale green amphibole, talc, chlorite, serpentine, and clay minerals along fractures or cleavage surfaces (Fig. F26); it shows no systematic variation in alteration intensity downhole (Fig. F17).

\section{Plagioclase}

Plagioclase is variably altered to prehnite, chlorite, and minor clay minerals as well as lesser amounts of secondary plagioclase, zeolite, and carbonate. The degree of plagioclase alteration increases downhole and is, on average, most pervasive in Unit III (Fig. F27; Tables T5, T6). Plagioclase is commonly replaced by patches of chlorite \pm amphibole, as in Hole U1415J, but in Hole U1415P these patches more commonly contain carbonate. Background replacement of plagioclase by prehnite is ubiquitous, and 
coarse-grained prehnite is more abundant in Hole U1415P thin sections than in Hole U1415J thin sections.

In thin sections of the gabbroic rock from Unit II, plagioclase is commonly fresh to moderately altered (0\%-50\%) (Fig. F27) to fine-grained prehnite + chlorite + minor clay minerals along microfractures. In some samples, chlorite forms a thin, continuous cryptocrystalline rim in plagioclase adjacent to olivine grains as part of the olivine corona reaction. Plagioclase is extensively altered to chlorite in vein halos, as is olivine. Carbonate is a common minor alteration product of plagioclase where it is commonly associated with chlorite or prehnite.

In the Unit III Troctolite Series, plagioclase generally is more altered than in the gabbroic rock of Unit II. Plagioclase is moderately to completely altered in Unit III (50\%-100\%). Prehnite is the most common replacement phase after plagioclase; chlorite also occurs especially along grain boundaries with olivine (Fig. F27). Plagioclase grains are locally completely replaced by both fine-grained and locally coarse grained prehnite (Fig. F28). Clinozoisite rarely forms part of the alteration assemblage. However, in the uppermost troctolitic rock of Unit III (Section 345U1415P-16R-1), plagioclase is only slightly altered $(10 \%-20 \%)$ to fine-grained prehnite and chlorite along microcracks, similar to the plagioclase alteration in Units I and II (Fig. F27).

An example of how the igneous lithology influences plagioclase alteration is shown in Figure F28. A contact between troctolite and olivine gabbro in the Troctolite Series of Unit III (Thin Section 140; Sample 345-U1415P-22R-2, 113-115 cm [Piece 8]) illustrates how the degree and mode of plagioclase alteration varies with lithology at the same depth within the hole. Alteration of plagioclase in the troctolitic portion of the piece is far more extensive than in the olivine gabbro portion.

\section{Sulfides}

Sulfide minerals occur as secondary phases throughout Units II and III. These minerals are commonly associated with alteration products after clinopyroxene and olivine and in serpentine and chlorite veins. Pyrite is common in all units and is widely disseminated as a trace phase in nearly all of the lithologic intervals. Fine-grained, euhedral, isolated pyrite grains commonly occur in serpentine veins after olivine (Fig. F29A). Pyrite is also commonly intergrown with clay minerals replacing olivine. Chalcopyrite forms isolated irregular grains associated with magnetite stringers within serpentine mesh and also in the chlorite replacements of plagioclase (Fig. F29B).
Sulfide assemblages of pentlandite \pm heazlewoodite (an alteration phase after pentlandite) are commonly mantled by magnetite and appear to be associated with serpentinization and talc alteration after olivine (Fig. F29C). Pyrrhotite, pentlandite, and pyrite or chalcopyrite form sulfide assemblages mantled by magnetite and locally show a sense of shear associated with deformation (Fig. F29D). These sulfide assemblages and their association with magnetite are typical of serpentinization and talc alteration of mafic and ultramafic rocks and likely do not reflect magmatic segregation processes (Groves et al., 1974; Eckstrand, 1975; Groves and Keays, 1979). Similar assemblages including pentlandite, chalcopyrite, pyrrhotite, and heazlewoodite were also observed in the troctolite and olivine gabbro recovered in Hole U1309D during IODP Expedition 304/305 at Atlantis Massif, $30^{\circ} \mathrm{N}$ on the Mid-Atlantic Ridge (Miller et al., 2009).

\section{Veins}

Seven vein types were identified in Hole U1415P (Fig. F30):

1. Clays;

2. Zeolite;

3. Amphibole + chlorite \pm prehnite, clays, zeolite;

4. Chlorite \pm zeolite, clays;

5. Chlorite + prehnite;

6. Prehnite \pm zeolite; and

7. Serpentine + prehnite \pm chlorite, zeolite, clays.

Types 4, 5, and 6 are the most common in Hole U1415P (Fig. F31). Prehnite and chlorite veins are common throughout Hole U1415P and occur with similar abundance in the Multitextured Layered Gabbro Series and Troctolite Series of Units II and III, respectively. In contrast, amphibole veins are more abundant in Unit II gabbro. Vein density is generally low, and several intervals lack veins entirely (Fig. F51; see also "Structural geology"). Microveins of prehnite commonly cut plagioclase in troctolite rocks. These veins often radiate away from serpentinized olivine and leave the bulk of the primary plagioclase unaltered. Vein networks are relatively uncommon but are more abundant in Unit II than in Unit III. Parallel, branched, or anastomosing connectivity is relatively common in Unit II but is rare in Unit III (Fig. F51).

Chlorite is commonly present in veins in association with zeolite, prehnite, amphibole, and/or serpentine. Chlorite shows various textures; the most common texture is cross-fiber, but elongated or radiating fibers are also common (Figs. F32, F33). Chlorite, prehnite, and chlorite + prehnite veins are equally common in Hole U1415P (Fig. F30). These veins are commonly associated with the serpentinization of 
olivine and the alteration of plagioclase to prehnite along microcracks in both Units II and III. Prehnite veins are commonly flanked by vein halos in which olivine and plagioclase alteration are more intense.

Veins composed of amphibole \pm chlorite are common in Units I and II, with several occurrences in most intervals, but are uncommon in Unit III (Fig. F30). Amphibole \pm chlorite veins may be crosscut by prehnite or chlorite veins (Fig. F33). Monomineralic zeolite or clay veins are abundant in Unit II, whereas prehnite or serpentine veins are less common. A number of chlorite veins in Unit II show partial replacement of chlorite by zeolite and clay minerals (Fig. F32). Pervasive replacement of chlorite by prehnite and carbonate is also commonly observed in Unit II.

Thick $(>0.5 \mathrm{~cm})$ serpentine veins occur in the lower sections of Unit III and contain abundant magnetite in the vein selvage, as well as thick $(1-1.5 \mathrm{~cm})$ vein halos with pervasive replacement of olivine by chlorite and plagioclase by prehnite. Thin clay and chlorite veins commonly crosscut serpentine veins. Veins filled with clay minerals or zeolites are rare in Unit III. A prominent vein of secondary clinopyroxene, confirmed by XRD, occurs in one of the troctolitic rock pieces (Sample 345-U1415P-23R1, 100-104 cm [Piece 14]; Fig. F34). A summary of XRD results for vein-filling materials and cataclasites is presented in Table T8.

Alteration is very intense in the halos of some veins, particularly serpentine veins in Unit III. Vein halos are more common in the Troctolite Series of Unit III than in the Multitextured Layered Gabbro Series of Unit II. In Unit II, halos range from 0.1 to $0.3 \mathrm{~cm}$ and are associated with chlorite veins. Halos are characterized by more intense alteration of primary phases and especially by pseudomorphic replacement of olivine and plagioclase by chlorite. Original igneous textures are generally well preserved (Fig. F35). In Unit III, vein halos range from $<0.5$ to $3 \mathrm{~cm}$ and are associated with chlorite veins as well as with prehnite and zeolite veins. These halos are characterized by pseudomorphic replacement of primary phases by chlorite and also commonly prehnite.

\section{Alteration in cataclastic zones}

In contrast to Hole U1415J, cataclastic zones are rare in Hole U1415P (see "Structural geology"). Fractures are more common but generally do not show any appreciable displacement. Where fractures show extension, veins filled with prehnite or chlorite are common. One cataclasite occurs in Core 345U1415P-10R at 45 mbsf (Thin Section 121; Sample 345-U1415P-10R-1, 131-134 cm [Piece 13]) (Fig.
F36). The cataclasite contains fragments of altered olivine, clasts of fine-grained prehnite, and randomly oriented fragments of clinopyroxene that are cemented by fine interlocking grains of prehnite. The cataclastic zone cuts the gabbroic host rock, and the clinopyroxene oikocrysts remain undeformed and preserve the optical continuity of apparently unconnected grains (Fig. F32A). Masses of chlorite are intergrown with minor amphibole-replaced olivine. Whereas the cataclasite cuts the previously altered gabbroic rock, small prehnite veins also cut the cataclastic zone, suggesting prehnite veining postdated cataclastic deformation. Overprinting chlorite/ prehnite alteration is associated with cataclasis and brittle fracturing and is relatively common in Hole U1415J but less common in the rock of Hole U1415P and occurs exclusively in Unit III troctolite (Fig. F35).

\section{Metamorphic conditions and history}

The mineral assemblages of the rock recovered in Hole U1415P suggest a range of temperature conditions from upper amphibolite to subgreenschist facies. Compared with Hole U1415J, coronitic textures (olivine + plagioclase $=$ tremolite + chlorite \pm talc $)$ are less developed. Minerals that clearly indicate hightemperature alteration conditions, such as brown amphibole and green spinel, were not found in Hole U1415P. These observations suggest limited hydrothermal activity under amphibolite facies conditions (Gillis, Mével, Allan, et al., 1993; Blackman et al., 2011; Nozaka and Fryer, 2011). The coronitic tremolite + chlorite assemblage is widespread in Hole U1415P, although it occurs primarily in Unit II and far less commonly in Unit III. This suggests more localized and limited hydrothermal activity under amphibolite facies conditions.

Widespread serpentinization and clay mineral formation after olivine suggest pervasive alteration under lower temperature subgreenschist facies conditions. Intense chlorite and prehnite alteration overprints the normal background alteration in vein halos and cataclastic rocks. This type of alteration was also observed in Hole U1415J. In contrast to the corona formation, serpentinization of olivine and prehnite formation after plagioclase are more intense in Unit III than in Unit II. Serpentine, prehnite, and clay minerals frequently show a tendency toward preferential distribution in densely fractured domains, at igneous contacts, and within troctolite intervals. One of the possible controlling factors of the low-temperature hydration in the lower crust could be the modal composition and structure of magmatic rock. It is clear that the mode of olivine controls the overall percent of alteration; intervals with higher olivine abundance are also 
characterized by higher alteration intensity. The occurrence of the prehnite + chlorite assemblage as fragmented clasts, matrix, and veins in the cataclastic zones suggests syntectonic alteration at subgreenschist facies conditions.

The temporal evolution of metamorphism in Hole U1415I is, from oldest to youngest,

- Development of olivine coronae,

- Serpentinization of olivine and cracking of adjacent plagioclase,

- Formation of amphibole veinlets (?), and

- Formation of low temperature prehnite veins and zeolite veins

\section{Structural geology}

\section{Magmatic structures}

\section{Macroscopic observations: lithologic Unit I}

The uppermost core (345-U1415P-2G) is a rubble/ sediment unit comprising mostly pelagic mud, sand, some olivine gabbro rubble, one piece of foliated olivine gabbro, and one basalt clast.

\section{Macroscopic observations: lithologic Unit II}

Coring in Unit II (Cores 345-U1415P-3R through Sample 345-U1415P-15R-1 [Piece 6] and ghost Core $4 \mathrm{G}$ ) recovered a $\sim 50 \mathrm{~m}$ thick sequence (Fig. F37) of olivine gabbro and orthopyroxene-bearing olivine gabbro hosting a diversity of textures. This sequence is called the Multitextured Layered Gabbro Series (see "Igneous petrology"). This heterogeneous interval reveals an extraordinary variety of textures that include variations in grain size $(0.1 \mathrm{~mm}$ to $>5$ $\mathrm{cm}$ ), crystal morphology (from equant annealed to disequilibrium skeletal and lobate grains), and mineral fabrics (from isotropic to strong) and consists of a sequence of interfingered intervals that range from homogeneously textured primitive orthopyroxenebearing olivine gabbro to dramatically banded or layered olivine gabbro.

\section{Layering/Banding}

Layering in Unit II can be divided into two broad categories: (1) more common, steeply dipping asymmetric and sometimes diffuse leucocratic banding (Fig. F38) and (2) less common, more regular, gently dipping grain size and modal layering (Fig. F39).

Variation in the steeply dipping leucocratic banding/ layering recorded in Unit II ranges from distinct (Fig. F38D) to weak (Fig. F38A, F38E). In the best examples, banding/layering can be traced through the entire diameter of the core, therefore confirming planar versus tubular geometry. Diffuse but locally subplanar plagioclase/orthopyroxene-rich leucocratic bands can be interpreted as layering, either originally horizontal or normal to a cooling surface. As significant rotation is likely in the history of these rocks, we use the term banding to avoid genetic connotations. The banding is defined by modal, grain size, and shape variations in plagioclase, olivine, orthopyroxene, and clinopyroxene and to a first order manifests as variably distinct leucocratic and melanocratic bands. These bands often display asymmetric distribution of minerals and mineral shapes/habits (Fig. F38B, F38D). The banding has variable dips $\left(4^{\circ}-90^{\circ}\right)$ and is often curved or folded but generally steeply dipping $\left(\right.$ mean $=63^{\circ} ;$ mode $=80^{\circ}$; standard deviation $=24^{\circ}$ ) (Fig. F37).

In Unit II, 51\% of the core (by length) contains some element of this style of banding, whether distinct or diffuse. This percentage is likely a reasonable estimate given the relatively good core recovery in Unit II. The banding extends discontinuously through the entire thickness of the cored unit, from Sample 345U1415P-4G-1, 62-93.5 cm (Piece 8; $13.2 \mathrm{mbsf}$ ), to Sample 15R-1, 16.5-22 cm (Piece 3; $64 \mathrm{mbsf}$ ). It seems unlikely that Hole U1415P intersected a single, variably natured anastomosing band. Several cycle boundaries appear to be crossed, some more distinct than others, so it is more likely that Unit II samples a steeply dipping multilayered unit that is at least $8.6 \mathrm{~m}$ thick (assuming the mode of the dip is the most representative dip of the unit). Bending or folding of the layers is suggestive of magmatic slumping. The original orientation of the banding is, at this point, unconstrained.

About $3 \%$ of the core in this unit exhibits simpler, gently dipping grain size and modal layering. This layering has planar, sharp, single boundaries between different rock types, such as those shown by orthopyroxene-bearing olivine gabbro and anorthositic gabbro in Figure F39. Other examples can be found in Sample 345-U1415P-4G-1, 8.5-18.0 cm (Piece 3), in which a $1.5 \mathrm{~cm}$ wide gabbronorite band cuts olivine gabbro (Fig. F40B), and in Sample 6R-1, $70.5-72.5 \mathrm{~cm}$ (Piece 7), in which a troctolite layer cuts olivine gabbro. It is likely that this layering formed under magmatic conditions.

\section{Enclaves and magma mixing}

Rarely, small (5-10 cm long) patches of homogeneous medium-grained orthopyroxene-bearing olivine gabbro reside within coarse-grained orthopyroxene-bearing olivine gabbro (e.g., Sample 345U1415P-7R-2, 9.5-54 cm [Piece 2]); these are interpreted to be enclaves, perhaps indicative of magma mixing or assimilation of already solidified material (see "Igneous petrology"" for further discussion). 


\section{Magmatic foliation}

The majority of olivine gabbro in Unit II is isotropic with no mineral shape-preferred orientation (SPO) (Fig. F40A, F40B). Only 6\% of the core pieces (by length) of Unit II exhibit recognizable foliation defined by olivine and/or plagioclase SPO. Where present, foliation strength is weak, and only rarely $(1.5 \%$ by length) does rock show moderate to strong foliation. The presence of foliation seems to be restricted to finer grained olivine gabbro. Where possible, estimates of foliation strength in core pieces were validated by examination of foliation in thin section. Foliation, where present (13 measurements), is predominantly planar, with dips ranging from $17^{\circ}$ to $88^{\circ}\left(\right.$ mean $=49^{\circ}$; standard deviation $\left.=14^{\circ}\right)($ Fig. F37 $)$.

\section{Microscopic observations: lithologic Unit II}

The majority of Unit II is isotopic and shows no, or at best weak, magmatic foliation. In contrast to gabbroic rock from Unit II in Hole U1415J, plagioclase shows less evidence for hypersolidus deformation, although some deformation twins, subgrain boundaries, and undulose extinction are present in most samples. Interestingly, Hole U1415P Unit II core also shows a greater range of plagioclase grain size (from $1 \mathrm{~cm}$ to $<0.1 \mathrm{~mm}$ ) within a single piece, with extreme degrees of annealing of the small grain sizes. In addition, the larger plagioclase crystals are commonly zoned, more so than in Hole U1415J Unit II core. Lastly, skeletal olivine in various geometries is much more common in Hole U1415P Unit II than in Hole U1415J Unit II.

Figure F40 shows two examples of gabbros that have no magmatic foliation and give an indication of the isotropic nature of most of the gabbros in Unit II. Sample 345-U1415P-3R-1, 120-123 cm (Piece 20A), is olivine gabbro with variable grain size (plagioclase ranges from 0.5 to $5.0 \mathrm{~mm}$ in diameter), hosting only weakly annealed plagioclase and minor deformation twins, undulose extinction, and locally developed subgrains (Fig. F40C). Sample 4G-1, 10-13 $\mathrm{cm}$ (Piece 3), reveals a sutured boundary between orthopyroxene-bearing gabbro and olivine-bearing gabbro. This orthopyroxene gabbro is isotropic and has weakly annealed, zoned plagioclase crystals that show bending and deformation twins (Fig. F40D), undulose extinction, and locally developed subgrains with curved boundaries. In contrast, the olivine-bearing gabbro hosts only weak magmatic foliation defined by plagioclase SPO yet is moderately annealed. Plagioclase crystals also show bending, deformation twins, undulose extinction, and rare subgrains. Olivine crystals show subgrain development.
As discussed earlier, Unit II only contains rare examples of distinct magmatic foliation (Fig. F41 shows one such example). Sample 345-U1415P-6R-2, 119$122 \mathrm{~cm}$ (Piece 14), contains a relatively coarse grained orthopyroxene and plagioclase vein that appears to intrude along the foliation and truncate the grains of a troctolitic gabbro (Fig. F41A, F41B). Very strong magmatic foliation is defined by both the preferred orientation and shape anisotropy of plagioclase crystals, which are commonly tabular and as long as $3 \mathrm{~mm}$ but normally $1-2 \mathrm{~mm}$ in length, with aspect ratios of as high as 10:1. Their [010] albite twin planes typically run parallel to the long axes of the crystals (Fig. F41C, F41D). Plagioclase crystals are locally bent with deformation twins, and rare subgrains are weakly annealed with scalloped grain boundaries. The skeletal olivine crystals show subgrains.

\section{Microstructures of layering/banding}

Figure F42 shows the microstructure of the banding observed in Sample 345-U1415P-6R-1, 101-103 cm (Piece 7C). Despite some alteration, the nature of the boundary is clearly heterogeneous, hosting a wide range of grain sizes. Coarse-grained clinopyroxene and (partially altered) equant olivine passing diagonally across the thin section form one side of an isotropic, medium-grained gabbro layer. Plagioclase shows rare deformation twins, undulose extinction, and partial annealing. Interstitial clinopyroxene in the gabbro layer increases away from the boundary with the coarse-grained olivine and clinopyroxene and appears to originate from another, but more restricted (Fig. F38B), coarse-grained clinopyroxene and olivine layer. The fine-grained troctolite layer beneath the banding contains equant, fine-grained $(0.5-0.1 \mathrm{~mm})$ plagioclase crystals, associated with delicate 1-10 $\mathrm{mm}$ diameter skeletal olivine crystals (Fig. F42C). These olivine crystals exhibit undulose extinction and subgrains. Plagioclase crystals inside the skeletal olivine are strongly annealed, a feature that is commonly seen in other cores from this unit (Fig. F42B). Figures F42D and F42E show other examples of fine-grained annealed plagioclase crystals. Crystals in Figure F42E are enclosed by an orthopyroxene oikocryst.

Figure F39 shows an example of the simple layering/ boundaries that are relatively rare in Unit II and indeed rare in Hole U1415P. Sample 345-U1415P-14R1, 16-25 cm (Piece 3), hosts a layer of orthopyroxene-bearing olivine gabbro within an anorthositic gabbro (Fig. F39A). The boundaries are sutured and defined by modal and grain size variation; the lower boundary of that layer is shown in Figure F39B. The 
orthopyroxene-bearing olivine gabbro has weak magmatic foliation defined by plagioclase SPO. Plagioclase shows significant grain size variation (0.1-3 $\mathrm{mm}$ ), sometimes occurring in large clusters (Fig. F39C) that show undulose extinction, subgrains, and deformation twins. The olivine is skeletal, locally with subgrains, and the orthopyroxene is interstitial. The anorthositic gabbro has weak to moderate magmatic foliation defined by plagioclase SPO. Plagioclase shows significant grain size variation (0.1-1 $\mathrm{mm}$ ) similar to that seen in the orthopyroxene-bearing olivine gabbro, with the larger grains showing zonation, rare undulose extinction, and deformation twins. In both the orthopyroxene-bearing olivine gabbro and the anorthositic gabbro, plagioclase occurs in small, highly annealed patches similar to those shown in Figures F42C-F42F. These textures suggest the rocks have undergone some recrystallization, perhaps as a result of a thermal input associated with intrusion of a new magma. Figure F39D shows another example of a plagioclase texture that shows subgrain development that may have captured partial annealing during a reheating event.

\section{Macroscopic observations: lithologic Unit III}

Unit III (Pieces 7, 8, and 9 in Section 345-U1415P15R-1 and Cores 345-U1415P-16R through 23R, 19G, 21G, 24G, and 25G) comprises a $38 \mathrm{~m}$ thick sequence of coarse-grained troctolite with little magmatic layering ( $2 \%$ of the piece length). Two endmember examples of troctolite are shown in Figure F43. Figure F43A shows an isotropic, clinopyroxene (5\%)-bearing troctolite with near cotectic proportions of olivine $(20 \%)$ and plagioclase $(75 \%)$. Figure F43B shows a weakly to moderately well foliated troctolite with more olivine $(35 \%)$, less plagioclase $(64.5 \%)$, and minimal clinopyroxene $(0.5 \%)$.

Of the core pieces from Unit III, 54\% (by length) exhibit magmatic foliation defined by olivine and plagioclase SPO (Fig. F43B). The foliation strength is weak and occasionally moderate and increases downhole. Some troctolite at the top of Unit III is isotropic. Magmatic foliation in Unit III is planar, with dips ranging from $12^{\circ}$ to $90^{\circ}$ (mean $=66^{\circ}$; standard deviation $=19^{\circ}$ ) (Fig. F37). The mean dip of Unit III is similar to that recorded by magmatic banding in Unit II $\left(63^{\circ}\right)$; however, no significance should be attached to this similarity, given the large standard deviations associated with these means and paucity of distinct, easily measured foliations. Figure F43C shows troctolite in Hole U1415J Unit III for comparison. The Hole U1415J Unit III troctolite is, on average, slightly more olivine-rich and has slightly stronger magmatic foliation but is inter- preted as a lithologic equivalent of troctolite in Hole U1415P Unit III.

\section{Microstructures}

Unit III is dominated by coarse-grained $(5 \mathrm{~mm})$ troctolite that is not seen in Unit II or Hole U1415J. This troctolite is generally more altered than olivine gabbro of Unit II and often contains mostly serpentinized olivine and pseudomorphs after plagioclase. Plagioclase crystals appear to be tabular and zoned and show undulose extinction, subgrains, and rare deformation twins. Olivine varies from tabular to rarely skeletal, sometimes showing subgrains and/or undulose extinction, and clinopyroxene is interstitial, occasionally forming rims around olivine grains.

\section{Intrusive contacts}

Two pieces from Unit III show discordant intrusive contacts between relatively fine grained olivine gabbro and troctolite. Figures F44B and F44E show the contact preserved in unoriented Sample 345U1415P-18R-1, 78-83 cm (Piece 7), truncating both olivine grains in the troctolite and is discordant to the steeply dipping olivine foliation in the same unit. The intrusive orthopyroxene-bearing olivine gabbro exhibits moderate magmatic foliation defined by plagioclase SPO that parallels the contact (Figs. F44E, F45F). Plagioclase crystals in the orthopyroxene-bearing olivine gabbro show subgrains, deformation twins, bent grains, and local patches of annealing. Tabular olivine crystals locally show undulose extinction. Figures F44C and F44F show the altered contact preserved in oriented Piece 8 (Sample 345-U1415P-22R-2, 113-115 cm). The boundary between troctolite and olivine gabbro again truncates steeply dipping olivine foliation and individual olivine grains in the troctolite (Fig. F44C). Olivine gabbro is isotropic in terms of magmatic foliation (Figs. F44F, F45D). Plagioclase crystals in olivine gabbro commonly show undulose extinction, deformation twins, and local patches of annealing.

Both of these contacts are clearly intrusive and indicate that Unit III was intruded by magma after sufficient crystallization of the troctolite to fracture. The intrusive bodies must be $<3 \mathrm{~m}$ thick because although a second contact for each was not recovered, core recovery limits their possible thickness.

One piece of anomalous, very fresh, fine-grained, moderately foliated olivine gabbro was also recovered near the top of Hole U1415P (Fig. F44A) in Sample 345-U1415P-3R-1, 31-34 cm (Piece 7). No contacts with the coarse-grained olivine gabbro of Unit II were recovered, but the similarity in mineralogy, grain size, alteration, and magmatic foliation raises 
the possibility that this piece also records either the same or similar late intrusive event. Figures F44D and F45A illustrate the moderate magmatic foliation of the olivine gabbro defined by plagioclase SPO that wraps locally around relatively large clinopyroxene crystals. Plagioclase crystals show common deformation twins, undulose extinction, and rare subgrains and moderately annealed grain boundaries. Clinopyroxene oikocrysts often have an amoeboid character and locally show subgrain development (Fig. F45B) and kinked cleavage with interfingering grain boundaries. Near-cumulus orthopyroxene and clinopyroxene host elongate and deformed plagioclase (Fig. F45C).

\section{Correlation of lithologic units in Holes U1415] and U1415P}

Based on primary mineralogy, rock types and textures, and magmatic fabric development (foliation, layering, and/or banding), three distinctive lithologic units were recovered at Site U1415 during Expedition 345. Coring in all holes recovered a surficial rubble unit, not considered here. Holes U1415I and U1415J were sufficiently close together that Unit II in both holes is interpreted to be contiguous (see "Structural geology" in the "Hole U1415J" chapter [Gillis et al., 2014e]).

Troctolite in Unit III in both Holes U1415J and $\mathrm{U} 1415 \mathrm{P}$ is lithologically similar, commonly has olivine-plagioclase foliation $(\sim 50 \%$ of the recovered rocks), contains little layering $(<6 \%)$, and is termed the Troctolite Series.

The Multitextured Layered Gabbro Series of Unit II in Hole U1415P is the third lithologic unit. This unit might also correspond with the few olivine gabbro pieces recovered in Hole U1415J (Piece 15 from Section 345-U1415J-9R-1, and Pieces 1, 2, and 3 from Section 10R-1) between the Hole U1415J layered Unit II gabbro and Unit III troctolite. This interpretation is supported by the recognition that one of these olivine gabbro intervals has a different magnetic remanence direction from that of Units II and III in Hole 1415J, suggesting that the olive gabbro comes from a different block (see "Paleomagnetism" in the "Hole U1415J" chapter [Gillis et al., 2014e] for further discussion).

In Hole U1415P, a fourth lithologic unit is defined to include the late intrusive fine-grained gabbro recognized in Unit III.

The thickness of the cored units (30-60 m) in Holes U1415I, U1415J, and U1415P; the lateral distance between boreholes (10-100 m); and the variable dip of their foliation/layering suggests that the units de- scribed above were recovered from large (30-60 m diameter) slump blocks.

\section{Crystal-plastic deformation}

A planar, weakly foliated zone of subsolidus crystalplastic deformation is noted over a thin interval $(<1$ $\mathrm{cm}$ ) in one piece from Unit II (Sample 345-U1415P15R-1, 43.5-44.25 cm [Piece 8]). No structurally continuous subsolidus crystal-plastic deformation was observed in the recovered section.

\section{Cataclastic deformation}

Brittle structures are only locally developed in Units II and III of Hole U1415P and comprise $<11 \%$ of the recovered pieces (Rank 1-5), with $<0.5 \%$ showing Ranks 3-5. Dip measurements of cataclastic fabrics in core from Hole U1415P were only possible in three short intervals and range from $48^{\circ}$ to $78^{\circ}$, with a mean of $62^{\circ}$.

Because of the very localized nature of cataclastic deformation, only three small pieces of cataclasite were recovered from Unit II (interval 345-U1415P-10R-1, $121-134 \mathrm{~cm}$ ) (Fig. F46). Macroscopically, the cataclastic deformation exhibits heterogeneous grain sizes and strong alteration associated with veins. Each piece shows strong preferred orientation and development of cataclastic foliation (Fig. F46A). Unfortunately, because of the small size of recovered pieces, none have measurable dips. Microscopically, this cataclastic deformation is characterized by angular to subrounded clasts of variably altered plagioclase and pyroxene, amphibole, and prehnite/chlorite in a fine-grained clast-derived matrix (Fig. F46B). This microstructure involves a zone of ultracataclasite comprising rounded clasts in a clay-dominated matrix (Fig. F46C) and is commonly cut by prehnite and minor chlorite veins in turn cut by another period of cataclastic deformation (Fig. F46A). Crosscutting relations indicate a complex succession of vein formation and brittle deformation.

In Unit III, cataclastic deformation is also very localized and preserved as cracked carbonate vein fill. In a sheared chlorite vein hosted in Piece 6 (Thin Section 129; Sample 345-U1415P-16R-1, 47-49 cm), the carbonate fibers were formed normal to the vein wall and subsequently pulled apart by later minor deformation (Fig. F47A, F47B).

\section{Alteration veins}

Alteration veins found in Hole U1415P fill existing cracks with metamorphic minerals including amphibole (tremolite-actinolite), chlorite, serpentine, prehnite, carbonates, zeolite, and clays (see "Meta- 
morphic petrology"). These veins bear witness to the late-stage fluid circulation in Hess Deep gabbroic rock. In Hole U1415P, however, vein thickness is typically $<1 \mathrm{~mm}$ and together represents an insignificant proportion of the core volume.

\section{Alteration vein density}

A semiquantitative scale, ranging from 0 (no veins) to 5 ( $>20$ intercepts with veins per $10 \mathrm{~cm}$ ), was used to describe downhole variations in vein density (see "Structural geology" in the "Methods" chapter [Gillis et al., 2014f]). The alteration vein density in Hole $\mathrm{U} 1415 \mathrm{P}$ is quite low in recovered intervals, in contrast with Hole U1415J. This observation is consistent with the absence of well-developed intervals of intense cataclasis in Hole U1415P core. Rare exceptions include (1) the few small pieces of fully serpentinized/chloritized troctolite and (2) highly altered edges of a few large pieces.

About half of the cored length is devoid of veins (Fig. F48). Where present, the vein density is either very low $(1$ vein per $10 \mathrm{~cm}$ ) or low $(<5$ veins per $10 \mathrm{~cm})$. Only $5 \%$ of the core has medium to high vein abundance (i.e. $>5$ veins per $10 \mathrm{~cm}$ ). No significant contrast in vein density exists between Units II and III. It is likely that a sampling bias exists because of the brittle nature of densely veined rocks. The frequent occurrence of core pieces bound at both ends by zones of alteration, some with slickenside striations, allows us to infer that intensely altered intervals (thick veins or intervals with high vein density) were not recovered. Examples of this relationship are common in troctolite from Unit III (Fig. F49).

\section{Vein shape and structure of vein-filling material}

Alteration veins in Hole U1415P form networks of regularly spaced planar features or are gently curved. Two crosscutting networks can locally be observed in the same piece. Irregular veins and anastomosing networks are much less frequent than in Hole U1415J. Most veins have clear-cut relationships with their igneous host; alteration halos are uncommon. One exception concerns the edge of some troctolite pieces corresponding to what we interpret as alteration and cracking fronts (Fig. F49), in which dense networks of subvertical veinlets are spatially correlated to a higher than average alteration degree; where the veins stop (vein tips), the alteration intensity drops abruptly.

Two faults are recognized in Unit III of Hole U1415P along alteration fronts (Samples 345-U1415P-16R-1, $63 \mathrm{~cm}$ [Piece 7], and 20R-1, $87 \mathrm{~cm}$ [Piece 8]). The serpentine at the edge of these pieces is strongly sheared with development of a well-defined lineation. Both faults have moderate dips $\left(\sim 30^{\circ}\right)$ and show a downward-dip slickenside lineation.

\section{Alteration vein dip}

Because of the reasonable recovery in Hole U1415P $(\sim 30 \%)$, vein orientation was measurable in many pieces. In 145 measurements, we observed slight preferred orientation in the vein dip distribution. Veins with a shallow to intermediate dip $\left(<60^{\circ}\right)$ and subvertical veins $\left(>75^{\circ}\right)$ are more abundant than veins with dips between $60^{\circ}$ and $75^{\circ}$. This bimodal distribution is observed in both Units II and III (Fig. F50).

No relationship between vein mineralogy and dip was observed (Fig. F51). We note that serpentine veins are more common in the lower part of the hole (olivine-rich troctolite in Unit III), whereas colorless amphibole is more common in the shallow part of the hole (gabbro of Unit II). Multiple stages of vein filling were frequently observed, with chlorite veins later filled with prehnite (see "Metamorphic petrology"). Crosscutting relationships are consistent with the inferred crystallization temperature of the minerals (e.g., chlorite veins crosscutting amphibole veins).

\section{Temporal evolution}

Temporal evolution of structures recovered in Hole U1415P is, from oldest to youngest,

- Intrusion of moderately high MgO magma into crust at the East Pacific Rise ridge axis. Undercooling may have led to the crystallization of skeletal olivine crystals. Possibly multiple intrusion/magma mixing events formed the Multitextured Layered Gabbro Series and magmatic banding/layering. Subsequent intrusion events may have led to thermal anomalies that caused recrystallization and annealing of plagioclase. Crystallization of troctolite cumulates and development of magmatic foliation initially occurred at high melt fractions ( $>40 \%)$;

- Some hypersolidus plastic deformation of the crystal mush (as shown by deformation twins, subgrain formation, and bent grains of plagioclase), likely concurrent with final development of the magmatic foliation;

- Discordant intrusion of small $(<3 \mathrm{~m}$ thick), finer grained dike- or sill-like gabbro bodies into Unit III;

- Likely static, near-solidus (above and below) annealing of plagioclase grain boundaries;

- Moderate- to low-temperature vein formation; and 
- Cataclasis associated with very minor moderate- to low-temperature faulting, which could be Cocos-Nazca or East Pacific Rise related.

\section{Inorganic geochemistry}

Chemical analyses were performed on 13 olivine gabbro and orthopyroxene-bearing olivine gabbro samples and on five troctolite samples. Sample selection was based on discussion with representatives from all expertise groups within the shipboard scientific party. Inductively coupled plasma-atomic emission spectroscopy was used for determining major and trace element concentrations, and gas chromatography was used for $\mathrm{S}, \mathrm{H}_{2} \mathrm{O}$, and $\mathrm{CO}_{2}$ quantification. Selected data are shown in Figures F61, F62, and F63 and fully reported in Table T1 in the "Geochemistry summary" chapter (Gillis et al., 2014c). Major and trace elements are reported on a volatilefree basis. The lowest part of the borehole (from Core 345-U1415P-21R through Core 23R) was not sampled for geochemistry because high-quality inductively coupled plasma-atomic emission spectroscopy major and trace element measurements could not be collected during the transit back to Panama.

\section{Multitextured Layered Gabbro Series}

The 13 analyzed olivine gabbro samples were selected from between 12 and 64 mbsf in lithologic Unit II, which represents the Multitextured Layered Gabbro Series. Minor orthopyroxene $(<1 \%-5 \%)$ was observed in seven olivine gabbro samples from Intervals 3, 18, 21, and 25 (see "Igneous petrology" and thin section descriptions in "Core descriptions").

Hole U1415P olivine gabbro and orthopyroxenebearing olivine gabbro is altered to various degrees, with loss on ignition (LOI) ranging from 1.7 to 4.8 $\mathrm{wt} \%$. The water content in gabbro (1.6-4.5 wt $\%$ ) correlates with LOI (Fig. F61). In contrast to the water concentrations, $\mathrm{CO}_{2}(0.03-0.20 \mathrm{wt} \%)$ and $\mathrm{S}(190-800$ ppm) contents are low and cannot be correlated with any of the other analyzed elements or with optically determined igneous and metamorphic observations reported in the thin section descriptions. Small sulfide minerals were observed within the Multitextured Layered Gabbro Series (see "Metamorphic petrology"); however, the sampling strategy goal of an average characterization of the cores was too wideranging to detect small-scale correlations between $\mathrm{S}$ concentration and these observed phases.

Hole U1415P olivine gabbro and orthopyroxenebearing olivine gabbro have primitive compositions, with high $\mathrm{Mg \#} \mathrm{(78-85),} \mathrm{low} \mathrm{SiO}_{2}$ (43.9-50.1 wt\%) and $\mathrm{TiO}_{2}(0.1-0.3 \mathrm{wt} \%)$ contents, and incompatible lithophile element (e.g., $\mathrm{Y}=3-11 \mathrm{ppm}$ ) contents. Similar to the gabbroic rock previously sampled during Expedition 345, the gabbro displays a wide range of $\mathrm{Al}_{2} \mathrm{O}_{3}(15.7-23.7 \mathrm{wt} \%)$ and $\mathrm{CaO}(9.8-20.9 \mathrm{wt} \%)$ compositions that contrast with their relatively restricted range of Mg\# (Fig. F62). These variations mainly reflect variations in the plagioclase and clinopyroxene modes of the analyzed gabbroic samples. The wide range of Sc (40-130 ppm) and V (9-36 ppm) contents are also attributed to differences in mineral mode, as these elements are more compatible in clinopyroxene compared to the other major mineral phases crystallized in the analyzed samples (plagioclase and olivine; see thin section descriptions in "Core descriptions"). Three olivine gabbro samples from Sections 345-U1415P-4G-1, 7R-1, and 8R-1 are significantly enriched in $\mathrm{Cr}(>1550 \mathrm{ppm})$ compared to adjacent olivine gabbro and orthopyroxenebearing olivine gabbro ( 150-810 ppm) (Fig. F62). These high $\mathrm{Cr}$ contents probably reveal the presence of minor spinel, a Cr-rich phase observed in some thin sections (see "Igneous petrology" and thin section descriptions in "Core descriptions"). High $\mathrm{Cr}$ values were also reported for three olivine gabbro samples in Hole U1415J; however, the occurrence of spinel was only rarely optically observed in Hole U1415J gabbro (see visual core descriptions in "Core descriptions").

Overall, olivine gabbro and orthopyroxene-bearing olivine gabbro sampled in Hole U1415P overlap in major and trace element compositions (Figs. F62, F63; see also Table T1 in the "Geochemistry summary" chapter [Gillis et al., 2014c]). The primitive geochemical characteristics of both olivine gabbro and orthopyroxene-bearing olivine gabbro are surprising because the occurrence of orthopyroxene in primary mineral assemblages is generally considered as an indicator of crystallization from evolved melts within the mid-ocean-ridge basalt gabbroic suites.

\section{Troctolite}

Five troctolite samples were selected from Cores 345U1415P-16R through 20R from the Troctolite Series (lithologic Unit III) in the lower part of Hole U1415P (below $\sim 64.2 \mathrm{mbsf}$ ).

Similar to previously analyzed Site U1415 plutonic rock, LOI (5.1-9.7 wt\%) and $\mathrm{H}_{2} \mathrm{O}$ contents (5.2-9.6 $\mathrm{wt} \%$ ) of Hole U1415P troctolite correlate positively, at approximately 1:1 (Fig. F61). In addition, both LOI and $\mathrm{H}_{2} \mathrm{O}$ concentrations are similar to the most altered troctolite in Hole U1415J and thus are significantly higher compared to those of other drilled plutonic lithologies. The extremely low measured $\mathrm{CO}_{2}$ (0.03-0.09 wt\%) and S (161-352 ppm) abundances 
cannot be correlated with other shipboard-acquired mineralogical and/or geochemical data sets.

Hole U1415P troctolite is $\mathrm{MgO}$ rich (18-30.8 $\mathrm{wt} \%$ ) and is distinguished from olivine gabbro by its higher Mg\# (87-89) and high $\mathrm{Ni}$ abundance (7001170 ppm) (Fig. F62; see also Table T1 in the "Geochemistry summary" chapter [Gillis et al., 2014c]), reflecting its elevated olivine content. The troctolite has variable $\mathrm{Al}_{2} \mathrm{O}_{3}$ compositions (11.8-21.1 wt\%) indicative of variations in the plagioclase mode, and overall it has lower $\mathrm{CaO}$ concentrations (8.1-12.4 $\mathrm{wt} \%)$ compared to neighboring gabbro, reflecting its lower clinopyroxene fraction. Hole U1415P troctolite has very low incompatible elements with $\mathrm{TiO}_{2}$ $(<0.04 \mathrm{wt} \%)$, Sc (3-9 ppm), V (14-23 ppm), and Y ( $<3$ ppm) (Fig. F63). Together with their refractory character, these compositions suggest precipitation from a primitive mantle melt for the Hole U1415P troctolite. As expected for primitive cumulates, Hole U1415P troctolite is Cr rich (120-1065 ppm); however, it is not as Cr-rich as some of the olivine gabbro samples, as would be expected for the most primitive end-member of a mid-ocean-ridge-cumulate suite (Fig. F62). These compositions may indicate either a bias in sampling Cr-rich phases in the troctolite series or a more complex petrogenetic history compared to a simple crystal fractionation process.

\section{Paleomagnetism}

\section{Remanence data}

\section{Continuous measurements}

Remanence measurements were made at $2 \mathrm{~cm}$ intervals on all archive-half core pieces longer than $\sim 9$ $\mathrm{cm}$. All archive-half cores were subjected to stepwise alternating field (AF) demagnetization at $5 \mathrm{mT}$ steps up to maximum peak fields of $80 \mathrm{mT}$. Remanence data and corresponding archive-half core point magnetic susceptibility data were filtered to preserve only data corresponding to the intervals where remanence measurements were made and to discard data obtained within $4.5 \mathrm{~cm}$ of piece ends.

For the purpose of characterization based on bulk magnetic parameters, the lithologies recovered in Hole U1415P are grouped into two categories. Group 1 consists of gabbroic rock (olivine gabbro, olivine gabbronorite, and orthopyroxene-bearing olivine gabbro) with a geometric mean natural remanent magnetism (NRM) intensity of $2.27 \mathrm{~A} / \mathrm{m}$ (range = $288 \mathrm{~mA} / \mathrm{m}$ to $7.35 \mathrm{~A} / \mathrm{m} ; n=261$ ) (Fig. F52), which is an order of magnitude higher than that observed in these lithologies in Hole U1415J (geometric mean NRM intensity of $22.6 \mathrm{~mA} / \mathrm{m}$ ). Group 2 consists of troctolitic rock (troctolite and troctolitic olivine gabbro) with a geometric mean NRM intensity of 5.95 $\mathrm{A} / \mathrm{m}$ (range $=1.5-14.5 \mathrm{~A} / \mathrm{m} ; n=98)$. The geometric mean magnetic susceptibilities of Group 1 and Group 2 samples are $617 \times 10^{-5}$ and $1792 \times 10^{-5} \mathrm{SI}$, respectively. These values are again higher than those observed for the same lithologies in Hole U1415J. Higher mean intensities and susceptibilities in troctolitic rock relative to gabbroic rock most likely reflect variable degrees of serpentinization of these more olivine-rich lithologies leading to the production of secondary magnetite (see "Metamorphic petrology").

Remanent magnetization directions were calculated by principal component analysis (PCA; Kirschvink, 1980) at all measurement points along the core pieces where linear components could be identified on orthogonal vector plots of demagnetization data. Only principal components with a maximum angular deviation (MAD) $<10^{\circ}$ were considered acceptable. Figure F53 shows representative examples of AF demagnetization behavior, and Figure F54 shows downhole variations in NRM and PCA pick inclinations, NRM and PCA pick intensities of magnetization, and low-field magnetic susceptibility measured using the Section Half Multisensor Logger (SHMSL). The majority of samples have an initially downwarddirected remanence, with evidence of inclination steepening caused by acquisition of a drilling-induced magnetization that is at least partially removed by low-field treatments $(<15 \mathrm{mT})$. This is followed by removal of a moderately inclined downward-directed component, typically by fields of 25-30 mT (Fig. F53A-F53F). The mean inclination of this component is $36.4^{\circ}\left(k=29.0 ; \alpha_{95}=1.7^{\circ} ; n=244\right)$, calculated using the Arason and Levi (2010) maximum likelihood method. During removal of this component, remanences typically migrate to the upper hemisphere, but no linear components with negative inclination are present. Instead, at demagnetization fields $>30 \mathrm{mT}$, remanence directions migrate back to the lower hemisphere and intensities of magnetization increase continuously up to the peak applied field of $80 \mathrm{mT}$. This is due to acquisition of spurious, laboratory-imparted anhysteretic remanent magnetization (ARM) along the $z$-axis of the superconducting rock magnetometer (SRM) system, which has been a characteristic problem of the SRM system observed during several IODP expeditions (e.g., Teagle, Ildefonse, Blum, and the Expedition 335 Scientists, 2012). In rare examples, linear components decaying toward the origin without significant ARM acquisition are successfully isolated (Fig. F53G, F53H), although in some cases this final component is directed along the $z$-axis of the SRM (Fig. F53G) 
and must be treated with caution as a potential ARM. Unfortunately, clear examples of demagnetization unaffected by ARM acquisition are limited in number. In the majority of cases, anomalous ARM in archive-half core samples prevent isolation of sufficient high-coercivity components to allow geological interpretation. The significance of the moderately inclined, downward-directed component with medium coercivity is discussed in "Reliability of linear remanence components in SRM data."

\section{Discrete samples}

Shipboard experiments were conducted on 34 discrete minicube samples from Hole U1415P. Two samples were AF demagnetized, and the remaining 32 samples were subjected to two cycles of low-temperature demagnetization (LTD) followed by thermal demagnetization. In all cases, remanent magnetization directions were calculated by PCA for all demagnetization intervals where linear components could be identified on orthogonal vector plots of demagnetization data. Only principal components with MAD $<10^{\circ}$ were considered acceptable (Table T9).

Samples from both gabbroic and troctolitic rock display well-defined linear remanence components following removal of variably developed drilling-induced magnetizations by low-temperature demagnetization. A selection of typical examples is shown in the orthogonal vector plots of Figure F55. Some samples display a bend in the thermal demagnetization path (e.g., Samples 345-U1415P-22R-2, 32 $\mathrm{cm}$, and 23R-1, $68 \mathrm{~cm}$ ) at temperatures of $\sim 450^{\circ} \mathrm{C}$ before decaying linearly toward the origin. In such cases, the highest unblocking temperature segment has been picked as the characteristic remanence component.

Unblocking temperature spectra for these samples are divided into two groups (Fig. F56). The first group loses $\sim 70 \%$ of remanence within $40^{\circ} \mathrm{C}$ of the magnetite Curie temperature $\left(585^{\circ} \mathrm{C}\right)$. Such discrete unblocking at high temperatures is characteristic of thermoremanent magnetizations (TRMs) carried by fine-grained (single domain and pseudosingle domain) grains of magnetite, and such remanences are unlikely to have been thermally overprinted after TRM acquisition. Hence, we interpret these components as the primary magnetization in these rocks, suitable for subsequent geological interpretation. The second group also exhibits stable, high unblocking temperature components but shows evidence for some unblocking at lower temperatures. Several samples have inflections in the demagnetization curve at temperatures between $400^{\circ}$ and $500^{\circ} \mathrm{C}$, which may be due to presence of magnetite grains with different grain size distributions (and hence unblocking temperatures) compared to those carrying the highest temperature component. This may reflect production of magnetite during alteration of these rocks (see "Metamorphic petrology").

\section{Reliability of linear remanence components in SRM data}

As noted previously, archive-half core data from the SRM system show a characteristic, moderately inclined linear remanence component at AF steps below $\sim 30 \mathrm{mT}$. This occurs after apparent removal of the drilling-induced remanence and prior to the acquisition of anhysteretic remanence at higher fields. In Hole U1415P, this component has a well-defined mean inclination of $37.5^{\circ}\left(k=20.7 ; \alpha_{95}=3.9^{\circ} ; n=69\right)$ but has no geological significance and is demonstrably an artifact of spurious origin.

As discussed in "Paleomagnetism" in the "Hole U1415J" chapter (Gillis et al., 2014e), there is poor to no correlation between well-defined discrete sample magnetization directions and the archive-half core data. Figure F57A shows a stereographic equal-area projection of the downward-directed linear component present in the majority of archive-half core demagnetization data. These data come from core pieces that are azimuthally unconstrained in the core reference frame yet show significant clustering toward northwest-northeast declinations. In contrast, discrete sample high unblocking temperature components (Fig. F57B) are widely scattered in declination, which is expected for data from core pieces that are free to rotate in the core barrel. These data further unequivocally confirm that the downward linear component in the archive-half core samples has no geological significance and is likely to reflect bias resulting from the radial component of the drilling-induced magnetization in these rocks (see Shipboard Scientific Party, 2003)

\section{Geological interpretation of inclination data from discrete samples}

The downhole distribution of inclinations of the highest unblocking temperature components in discrete samples from Hole U1415P are illustrated in Figure F58 together with associated NRM inclinations. Remanences migrate from dominantly positive NRM inclinations to negative PCA inclinations during demagnetization, reflecting removal of the downward-directed drilling-induced magnetization. With four exceptions (red), all PCA inclinations are negative. These four anomalous samples all come from within the uppermost $6 \mathrm{~cm}$ of their respective core sections and are likely to be unrepresentative of 
the sampled sections. They were therefore excluded from subsequent analysis.

The remaining data are divided into the units defined on the basis of petrological characteristics (Units II and III; see "Igneous petrology") and mean inclinations calculated using the Arason and Levi (2010) maximum likelihood method. This identifies a significant difference in mean inclination between units:

Unit II mean inclination $=-54.9^{\circ}\left(k=13.0 ; \alpha_{95}=\right.$ $\left.9.2^{\circ} ; n=21\right)$.

Unit III mean inclination $=-30.8^{\circ}\left(k=17.8 ; \alpha_{95}=\right.$ $\left.13.5^{\circ} ; n=8\right)$.

These data indicate substantial rotation of the cored section relative to the expected geocentric axial dipole reference inclination of $\pm 4.7^{\circ}$. The distinct mean inclinations of Units II and III also indicate that two displaced blocks with independent rotation histories were sampled in Hole U1415P. Units II and III should therefore be treated separately in lithologic and structural syntheses. In the absence of reoriented samples from this hole, it is impossible to place constraints on the net or relative rotation of the units using the paleomagnetic data.

\section{Magnetic susceptibility, NRM intensity, and Königsberger ratio}

In mafic igneous rock, low-field magnetic susceptibility $(k)$ is principally controlled by the volume concentration of magnetite. NRM variability is also controlled by variations in magnetite content but may also be influenced by variability in the magnitude of drilling-induced remanent magnetizations. The relation of NRM intensity and susceptibility is expressed by the Königsberger ratio $(Q)$, which is defined as the ratio of remanent to induced magnetization in rock, where induced magnetization equals the product of $k$ (SI) and the geomagnetic field strength $(\mathrm{A} / \mathrm{m})$. Values of $Q>1$ indicate that remanence dominates the magnetization of a rock unit.

Figure F59 shows a log-log plot of NRM intensity against $k$ for archive-half core and discrete samples in Hole U1415P together with lines of equal $Q$ calculated for a $25 \mathrm{~A} / \mathrm{m}$ field. The majority of archive-half core data plot close to $Q=10.0$, whereas lower NRM intensities in discrete samples result in $Q$ values of 1.0-10.0. The discrepancy between these measurements may result from decay of viscous drilling-related magnetizations in the time between SRM and discrete sample analyses. These data suggest that lithologies sampled in Hole U1415P may contribute a significant fraction to marine magnetic anomalies when in situ. However, caution is required in the in- terpretation of $Q$ ratios calculated for these samples, as NRM intensities (particularly in the archive-half core samples) may be artificially increased by drilling-induced magnetization.

\section{Anisotropy of magnetic susceptibility}

Anisotropy of magnetic susceptibility (AMS) was measured from 35 discrete samples in Hole U1415P (Table T10). Each sample was measured three times to maintain quality control on any shipboard noise. A bootstrap technique was used to average these three measurements to provide the AMS eigenparameters for each discrete sample. All discrete samples have small $\left(<3.5^{\circ}\right)$ bootstrapped confidence ellipses around their eigenvectors that indicate consistent and repeatable AMS fabric measurements. Eigenvectors from all 35 samples are shown separated onto two equal-area stereographic projections in Figure F60 using the Hole U1415P Unit II/III boundary based on different petrological characteristics (see "Igneous petrology"). Susceptibility tensors are weakly to moderately anisotropic (corrected anisotropy degree $\left[P^{\prime}\right]<1.35$; mean $=1.17$ ) (Jelinek, 1981), and all three ellipsoid shapes (triaxial, oblate, and prolate) are present in these samples (Fig. F60C). Bulk susceptibilities range from $8.95 \times 10^{-4}$ to $4.63 \times$ $10^{-2} \mathrm{SI}$, with an average of $1.64 \times 10^{-2}$ SI that indicates predominance of ferromagnetic mineral contributions to the AMS signal in most samples.

Structural measurements of magmatic foliation in Hole U1415P show a range of relationships with the AMS fabrics. Although most of the samples were generally nearly isotropic, 9 of 19 samples with structurally measured fabrics show close correspondence of the minimum AMS eigenvector $\left(k_{\min }\right)$ to the magmatic foliation pole. Foliation orientations primarily range from moderately to steeply eastward dipping within the core reference frame (Fig. F60A). Reasonably consistent AMS fabrics are found in the upper portion of Hole U1415P (above $~ 64$ mbsf), whereas a wider range of eigenvector directions is observed below, as shown on Figures F60A and F60B. Overall, almost half of the samples with measured magmatic foliation show a close agreement of AMS magnetic foliation (average solid angle between $k_{\min }$ and magmatic foliation pole $<45^{\circ}$ ). The other half of the samples show variable relationships of AMS eigenvectors with respect to the magmatic foliation, with solid angles between $k_{\min }$ and magmatic foliation pole $>45^{\circ}$. As noted above, samples that exhibit a poor agreement between the AMS and structurally measured fabrics are typically isotropic or show very weak hints of mineral alignment. 


\section{Physical properties}

Physical properties of the gabbroic rock pieces recovered in Hole U1415P were characterized through a series of measurements on whole-core sections, halfcore sections, half-core pieces, and discrete samples as described in "Physical properties" in the "Methods" chapter (Gillis et al., 2014f). We measured gamma ray attenuation (GRA) density and magnetic susceptibility on the Whole-Round Multisensor Logger (WRMSL); natural gamma radiation (NGR) on the Natural Gamma Ray Logger (NGRL); point magnetic susceptibility, reflectance spectroscopy, and colorimetry on the SHMSL; and thermal conductivity, compressional wave velocity, density, and porosity on discrete samples. The rock names reported in data tables correspond to the primary lithologies assigned by the igneous group (Tables T11, T12). Data are summarized as a function of depth in Figure F64. Discrete sample data from ghost Core 345-U1415P$4 \mathrm{G}$ are shown in Figure F64 together with the other data from routine RCB cores because the corresponding interval is well constrained (12.4-19.5 mbsf); WRMSL and SHMSL data from ghost cores are not shown in this figure.

Raw GRA density, magnetic susceptibility, reflectance spectrophotometry, and colorimetry data were uploaded to the Laboratory Information Management System database and subsequently filtered following the procedures described in "Physical properties" in the "Methods" chapter (Gillis et al., 2014f) to remove spurious points that correspond to empty intervals in the liner, broken pieces, and pieces that were too small. Both raw and filtered data are provided in PHYSPROP in "Supplementary material."

\section{Multisensor core logger data}

\section{Natural gamma radiation}

In Hole U1415P, 29 of 38 core sections were measured on the NGRL; other sections contained pieces too small to provide reliable data with this instrument. NGR is, overall, very low $(0-4.3 \mathrm{cps})$ and is generally significantly lower than background level ( $\sim 5$ cps), except in Core $345-U 1415 \mathrm{P}-23 \mathrm{R}$ where two intervals return significantly higher counts $(3.6 \mathrm{cps}$ in Sample 345-U1415P-23R-1, 8-22 cm [Piece 2], and $4.3 \mathrm{cps}$ in Sample 23R-2, 37-50 cm [Piece 4]) (Fig. F64). NGR values in ghost Core $345-\mathrm{U} 1415 \mathrm{P}-4 \mathrm{G}$ are in the same range as those in routine $\mathrm{RCB}$ cores (0.15-1.4 cps).

\section{Gamma ray attenuation density}

In Hole U1415P, 33 of 38 core sections were measured on the WRMSL. GRA density measurements are volume dependent, and filtered data range be- tween 1.46 and $2.74 \mathrm{~g} / \mathrm{cm}^{3}$, with an average of 2.39 $\mathrm{g} / \mathrm{cm}^{3}$ (94\% of the values are $<2.5 \mathrm{~g} / \mathrm{cm}^{3}$ and are not shown in Fig. F64). These values are generally significantly lower than bulk density measured on discrete samples in the same cores.

\section{Magnetic susceptibility}

Magnetic susceptibility was measured on both the WRMSL (33 core sections) and SHMSL (35 core sections). The whole-round core measurements are volume measurements that give an average apparent susceptibility value over an $8 \mathrm{~cm}$ long interval, whereas the SHMSL values are given by point measurements (see "Physical properties" in the "Methods" chapter [Gillis et al., 2014f]). When measured on whole-round cores, magnetic susceptibility is generally underestimated, with values significantly lower than point magnetic susceptibility (Fig. F64). The mean magnetic susceptibility of rocks recovered in Hole U1415P is generally low $\left(\sim 1350 \times 10^{-5} \pm 1330\right.$ $\times 10^{-5}$ SI for point magnetic susceptibility), reflecting the absence of magmatic Fe-Ti oxides.

\section{Reflectance spectroscopy and colorimetry}

Reflectance spectroscopy and colorimetry data were systematically acquired, together with point magnetic susceptibility data, using the SHMSL with a measurement interval of $1 \mathrm{~cm}$. The mean values of reflectance and chromaticity parameters $\mathrm{a}^{*}, \mathrm{~b}^{*}$ and $\mathrm{L}^{*}$ are $0.6 \pm 0.5,-6.6 \pm 1.4$, and $\sim 40.7 \pm 9.2$, respectively.

\section{Discrete sample measurements}

\section{Moisture and density}

Bulk density, grain density, and porosity were calculated from measurements on 29 cubic samples $(2 \mathrm{~cm}$ $\times 2 \mathrm{~cm} \times 2 \mathrm{~cm}$ ) taken from the working-half sections (Table T11; Fig. F64). These samples comprise two rock types, olivine gabbro (including some orthopyroxene-bearing intervals) and troctolite. The average bulk density and grain density are $2.82 \pm 0.06$ and $2.84 \pm 0.06 \mathrm{~g} / \mathrm{cm}^{3}$, respectively (Table T12), and are similar to densities measured at Hess Deep (Ocean Drilling Program [ODP] Leg 147 Site 894) (Fig. F65). Troctolite has average grain densities $\left(2.76 \pm 0.03 \mathrm{~g} / \mathrm{cm}^{3}\right)$ that are $\sim 0.1 \mathrm{~g} / \mathrm{cm}^{3}$ lower than those of olivine gabbro $\left(2.86 \pm 0.05 \mathrm{~g} / \mathrm{cm}^{3}\right)$. This difference reflects the average differences in background alteration for these lithologies, which is primarily related to olivine contents because olivine is generally more strongly altered than plagioclase and clinopyroxene in olivine-rich rocks (Fig. F66; see also "Metamorphic petrology"). Porosity is generally very low, ranging from $0.4 \%$ to $1.8 \%$ (Fig. F64), reflecting the 
low degree of brittle deformation in these rocks (see "Structural geology").

\section{$P$-wave velocity}

The same 29 cubic samples used for moisture and density analyses were measured for $P$-wave velocities $\left(V_{\mathrm{P}}\right)$ along the three principal directions $(x, y$, and $z)$ in the core reference frame (see Fig. F2 in the "Methods" chapter [Gillis et al., 2014f]). Results are listed in Tables T11 and T12 and plotted in Figures F64 and F65. Average $V_{\mathrm{P}}$ is $6.25 \pm 0.13 \mathrm{~km} / \mathrm{s}$, and the apparent anisotropy varies from $0.7 \%$ to $5.9 \%$. As detailed in "Physical properties" in the "Methods" chapter (Gillis et al., 2014f) and "Physical properties" in the "Hole U1415I" chapter (Gillis et al., $2014 \mathrm{~d}$ ), the precision of our $V_{\mathrm{P}}$ measurements is $\sim 2 \%$. Hence, the relatively low measured apparent anisotropies should be treated with caution.

In Figure $\mathrm{F} 65$, results for $V_{\mathrm{P}}$ and grain density measurements on samples at Site U1415 are compared with those made during previous ODP legs and IODP expeditions on gabbroic samples from fast-spreading and slow-spreading oceanic crust. $V_{\mathrm{P}}$ values are consistent with measurements made at Hess Deep (Site 894). $V_{\mathrm{p}}$ measurements made on board over time show a large dispersion (Fig. F65), which probably cannot be solely explained by petrophysical variations (note, for example, the $\sim 1-1.5 \mathrm{~km} / \mathrm{s}$ difference in velocity between Hole $735 \mathrm{~B}$ data and data from other slow-spreading crust locations even though they have similar composition, porosity, and alteration). These data should therefore be treated with caution.

Although the range of measured porosities is small, measured velocities at room pressure show a general inverse correlation with porosity (Fig. F67).

\section{Thermal conductivity}

Thermal conductivity was measured in 20 gabbroic rock samples ( $\geq 8 \mathrm{~cm}$ long and representative of the various recovered lithologies) taken at irregularly spaced intervals downhole in Hole U1415P (Tables T12, T13; Fig. F64). Measured values range from 2.10 to $3.13 \mathrm{~W} /(\mathrm{m} \cdot \mathrm{K})$ and are averages of $8-10$ measurements for each piece, with a standard deviation $<1.6 \%$. Overall, thermal conductivity values measured during Expedition 345 on samples from Holes U1415I, U1415J, and U1415P are of very good quality, with a standard deviation of measurement on a single piece that is generally significantly lower than $2 \%$. These values are in agreement with thermal conductivities measured in similar lithologies during previous ODP legs and IODP expeditions (Fig. F68).

\section{References}

Arason, P., and Levi, S., 2010. Maximum likelihood solution for inclination-only data in paleomagnetism. Geophys. J. Int., 182(2):753-771. doi:10.1111/j.1365246X.2010.04671.X

Blackman, D.K., Ildefonse, B., John, B.E., Ohara, Y., Miller, D.J., Abe, N., Abratis,M., Andal, E.S., Andreani, M., Awaji, S., Beard, J.S., Brunelli, D., Charney, A.B., Christie, D.M., Collins, J., Delacour, A.G., Delius, H., Drouin, M., Einaudi, F., Escartín, J. Frost, B.R., Früh-Green, G., Fryer, P.B., Gee, J.S., Godard, M., Grimes, C.B., Halfpenny, A., Hansen, H.-E., Harris, A.C., Tamura, A., Hayman, N.W., Hellebranc, E., Hirose, T., Hirth, J.G., Ishimaru, S., Johnson, K.T.M., Karner, G.D., Linek, M., MacLeod, C.J., Maeda, J., Mason, O.U., McCaig, A.M., Michibayashi, K., Morris, A., Nakagawa, T., Nozaka, T., Rosner, M., Searle, R.C., Suhr, G., Tominaga, M., von der Handt, A., Yamasaki, T., and Zhao, X., 2011. Drilling constraints on lithospheric accretion and evolution at Atlantis Massif, Mid-Atlantic Ridge, $30^{\circ}$ N. J. Geophys. Res.: Solid Earth, 116(B7):B07103. doi:10.1029/ 2010JB007931

Cannat, M., Karson, J.A., Miller, D.J., et al., 1995. Proc. ODP, Init. Repts., 153: College Station, TX (Ocean Drilling Program). doi:10.2973/odp.proc.ir.153.1995

Donaldson, C.H., 1976. An experimental investigation of olivine morphology. Contrib. Mineral. Petrol., 57(2):187213. doi:10.1007/BF00405225

Eckstrand, O.R., 1975. The Dumont serpentinite; a model for control of nickeliferous opaque mineral assemblages by alteration reactions in ultramafic rocks. Econ. Geol., 70(1):183-201. doi:10.2113/gsecongeo.70.1.183

Expedition 304/305 Scientists, 2006. Site U1309. In Blackman, D.K., Ildefonse, B., John, B.E., Ohara, Y., Miller, D.J., MacLeod, C.J., and the Expedition 304/305 Scientists, Proc. IODP, 304/305: College Station, TX (Integrated Ocean Drilling Program Management International, Inc.). doi:10.2204/ iodp.proc.304305.103.2006

Expedition 309/312 Scientists, 2006. Site 1256. In Teagle, D.A.H., Alt, J.C., Umino, S., Miyashita, S., Banerjee, N.R., Wilson, D.S., and the Expedition 309/312 Scientists. Proc. IODP, 309/312: Washington, DC (Integrated Ocean Drilling Program Management International, Inc.). doi:10.2204/iodp.proc.309312.103.2006

Gillis, K.M., Snow, J.E., Klaus, A., Guerin, G., Abe, N., Akizawa, N., Ceuleneer, G., Cheadle, M.J., Adrião, Á., Faak, K., Falloon, T.J., Friedman, S.A., Godard, M.M., Harigane, Y., Horst, A.J., Hoshide, T., Ildefonse, B., Jean, M.M., John, B.E., Koepke, J.H., Machi, S., Maeda, J., Marks, N.E., McCaig, A.M., Meyer, R., Morris, A., Nozaka, T., Python, M., Saha, A., and Wintsch, R.P., 2014a. Bench site survey. In Gillis, K.M., Snow, J.E., Klaus, A., and the Expedition 345 Scientists, Proc. IODP, 345: College Station, TX (Integrated Ocean Drilling Program). doi:10.2204/iodp.proc.345.103.2014

Gillis, K.M., Snow, J.E., Klaus, A., Guerin, G., Abe, N., Akizawa, N., Ceuleneer, G., Cheadle, M.J., Adrião, Á., 
Faak, K., Falloon, T.J., Friedman, S.A., Godard, M.M., Harigane, Y., Horst, A.J., Hoshide, T., Ildefonse, B., Jean, M.M., John, B.E., Koepke, J.H., Machi, S., Maeda, J., Marks, N.E., McCaig, A.M., Meyer, R., Morris, A., Nozaka, T., Python, M., Saha, A., and Wintsch, R.P., 2014b. Expedition 345 summary. In Gillis, K.M., Snow, J.E., Klaus, A., and the Expedition 345 Scientists, Proc. IODP, 345: College Station, TX (Integrated Ocean Drilling Program). doi:10.2204/iodp.proc.345.101.2014

Gillis, K.M., Snow, J.E., Klaus, A., Guerin, G., Abe, N., Akizawa, N., Ceuleneer, G., Cheadle, M.J., Adrião, Á., Faak, K., Falloon, T.J., Friedman, S.A., Godard, M.M., Harigane, Y., Horst, A.J., Hoshide, T., Ildefonse, B., Jean, M.M., John, B.E., Koepke, J.H., Machi, S., Maeda, J., Marks, N.E., McCaig, A.M., Meyer, R., Morris, A., Nozaka, T., Python, M., Saha, A., and Wintsch, R.P., 2014c. Geochemistry summary. In Gillis, K.M., Snow, J.E., Klaus, A., and the Expedition 345 Scientists, Proc. IODP, 345: College Station, TX (Integrated Ocean Drilling Program). doi:10.2204/iodp.proc.345.114.2014

Gillis, K.M., Snow, J.E., Klaus, A., Guerin, G., Abe, N., Akizawa, N., Ceuleneer, G., Cheadle, M.J., Adrião, Á., Faak, K., Falloon, T.J., Friedman, S.A., Godard, M.M., Harigane, Y., Horst, A.J., Hoshide, T., Ildefonse, B., Jean, M.M., John, B.E., Koepke, J.H., Machi, S., Maeda, J., Marks, N.E., McCaig, A.M., Meyer, R., Morris, A., Nozaka, T., Python, M., Saha, A., and Wintsch, R.P., 2014d. Hole U1415I. In Gillis, K.M., Snow, J.E., Klaus, A., and the Expedition 345 Scientists, Proc. IODP, 345: College Station, TX (Integrated Ocean Drilling Program). doi:10.2204/iodp.proc.345.109.2014

Gillis, K.M., Snow, J.E., Klaus, A., Guerin, G., Abe, N., Akizawa, N., Ceuleneer, G., Cheadle, M.J., Adrião, Á., Faak, K., Falloon, T.J., Friedman, S.A., Godard, M.M., Harigane, Y., Horst, A.J., Hoshide, T., Ildefonse, B., Jean, M.M., John, B.E., Koepke, J.H., Machi, S., Maeda, J., Marks, N.E., McCaig, A.M., Meyer, R., Morris, A., Nozaka, T., Python, M., Saha, A., and Wintsch, R.P., 2014e. Hole U1415J. In Gillis, K.M., Snow, J.E., Klaus, A., and the Expedition 345 Scientists, Proc. IODP, 345: College Station, TX (Integrated Ocean Drilling Program). doi:10.2204/iodp.proc.345.110.2014

Gillis, K.M., Snow, J.E., Klaus, A., Guerin, G., Abe, N., Akizawa, N., Ceuleneer, G., Cheadle, M.J., Adrião, Á., Faak, K., Falloon, T.J., Friedman, S.A., Godard, M.M., Harigane, Y., Horst, A.J., Hoshide, T., Ildefonse, B., Jean, M.M., John, B.E., Koepke, J.H., Machi, S., Maeda, J., Marks, N.E., McCaig, A.M., Meyer, R., Morris, A., Nozaka, T., Python, M., Saha, A., and Wintsch, R.P., 2014f. Methods. In Gillis, K.M., Snow, J.E., Klaus, A., and the Expedition 345 Scientists, Proc. IODP, 345: College Station, TX (Integrated Ocean Drilling Program). doi:10.2204/iodp.proc.345.102.2014

Gillis, K., Mével, C., Allan, J., et al., 1993. Proc. ODP, Init. Repts., 147: College Station, TX (Ocean Drilling Program). doi:10.2973/odp.proc.ir.147.1993

Groves, D.I., Hudson, D.R., and Hack, T.B., 1974. Modification of iron-nickel sulfides during serpentinization and talc-carbonate alteration at Black Swan, Western Austra- lia. Econ. Geol., 69(8):1265-1281. doi:10.2113/gsecongeo.69.8.1265

Groves, D.I., and Keays, R.R., 1979. Mobilization of oreforming elements during alteration of dunites, Mt. Keith-Betheno, Western Australia. Can. Mineral., 17(2):373-389. http://canmin.geoscienceworld.org/ content $/ 17 / 2 / 373$.extract

Hanna, H.D., 2004. Geochemical variations in basaltic glasses from an incipient rift and upper level gabbros from Hess Deep, eastern equatorial Pacific [M.Sc. thesis]. Duke Univ., Durham.

Hékinian, R., Bideau, D., Francheteau, J., Cheminee, J.L., Armijo, R., Lonsdale, P., and Blum, N., 1993. Petrology of the East Pacific Rise crust and upper mantle exposed in Hess Deep (eastern equatorial Pacific). J. Geophys. Res.: Solid Earth, 98(B5):8069-8094. doi:10.1029/ 92JB02072

Jelinek, V., 1981. Characterization of the magnetic fabric of rocks. Tectonophysics, 79(3-4):T63-T67. doi:10.1016/ 0040-1951(81)90110-4

Kirchner, T.M., and Gillis, K.M., 2012. Mineralogical and strontium isotopic record of hydrothermal processes in the lower ocean crust at and near the East Pacific Rise. Contrib. Mineral. Petrol., 164(1):123-141 doi:10.1007/ s00410-012-0729-5[†]

Kirschvink, J.L., 1980. The least-squares line and plane and the analysis of palaeomagnetic data. Geophys. J. R. Astron. Soc., 62(3):699-718. doi:10.1111/j.1365246X.1980.tb02601.X

Miller, D.J., Eisenbach, T., and Luo, Z.P., 2009. Data report: characterization of sulfide minerals from gabbroic and ultramafic rocks by electron microscopy. In Blackman, D.K., Ildefonse, B., John, B.E., Ohara, Y., Miller, D.J., MacLeod, C.J., and the Expedition 304/305 Scientists, Proc. IODP, 304/305: College Station, TX (Integrated Ocean Drilling Program Management International, Inc.). doi:10.2204/iodp.proc.304305.203.2009

Miller, D.J., Iturrino, G.J., and Christensen, N.I., 1996. Geochemical and petrological constraints on velocity behavior of lower crustal and upper mantle rocks from the fast-spreading ridge at Hess Deep. In Mével, C., Gillis, K.M., Allan, J.F., and Meyer, P.S. (Eds.), Proc. ODP, Sci. Results, 147: College Station, TX (Ocean Drilling Program), 477-490. doi:10.2973/ odp.proc.sr.147.028.1996

Natland, J.H., and Dick, H.J.B., 2009. Paired melt lenses at the East Pacific Rise and the pattern of melt flow through the gabbroic layer at a fast-spreading ridge. Lithos, 112(1-2):73-86. doi:10.1016/ j.lithos.2009.06.017

Nozaka, T., and Fryer, P., 2011. Alteration of the oceanic lower crust at a slow-spreading axis: insight from veinrelated zoned halos in olivine gabbro from Atlantis Massif, Mid-Atlantic Ridge. J. Petrol., 52(4):643-664. doi:10.1093/petrology/egq098

Pedersen, R.B., Malpas, J., and Falloon, T., 1996. Petrology and geochemistry of gabbroic and related rocks from Site 894, Hess Deep. In Mével, C., Gillis, K.M., Allan, J.F., 
and Meyer, P.S. (Eds.), Proc. ODP, Sci. Results, 147: College Station, TX (Ocean Drilling Program), 3-19. doi:10.2973/odp.proc.sr.147.001.1996

Perk, N.W., Coogan, L.A., Karson, J.A., Klein, E.M., and Hanna, H.D., 2007. Petrology and geochemistry of primitive lower oceanic crust from Pito Deep: implications for the accretion of the lower crust at the southern East Pacific Rise. Contrib. Mineral. Petrol., 154(5):575590. doi:10.1007/s00410-007-0210-Z

Saunders, A.D., Fornari, D.J., Joron, J.-L., Tarney, J., and Treuil, M., 1982. Geochemistry of basic igneous rocks, Gulf of California, Deep Sea Drilling Project Leg 64. In Curray, J.R., Moore, D.G., et al. (Eds.), Init. Repts. DSDP, 64: Washington, DC (U.S. Govt. Printing Office), 595642. doi:10.2973/dsdp.proc.64.112.1982

Shipboard Scientific Party, 1989. Site 735. In Robinson, P.T., Von Herzen, R., et al., Proc. ODP, Init. Repts., 118: College Station, TX (Ocean Drilling Program), 89-222. doi:10.2973/odp.proc.ir.118.107.1989

Shipboard Scientific Party, 1993. Site 894. In Gillis, K., Mével, C, Allan, J., et al., Proc. ODP, Init. Repts., 147: Col- lege Station, TX (Ocean Drilling Program), 45-108. doi:10.2973/odp.proc.ir.147.103.1993

Shipboard Scientific Party, 1999. Site 735. In Dick, H.J.B., Natland, J.H., Miller, D.J., et al., Proc. ODP, Init. Repts., 176: College Station, TX (Ocean Drilling Program), 1314. doi:10.2973/odp.proc.ir.176.103.1999

Shipboard Scientific Party, 2003. Site 1256. In Wilson, D.S., Teagle, D.A.H., Acton, G.D., Proc. ODP, Init. Repts., 206: College Station, TX (Ocean Drilling Program), 1-396. doi:10.2973/odp.proc.ir.206.103.2003

Shipboard Scientific Party, 2004. Site 1271. In Kelemen, P.B., Kikawa, E., Miller, D.J., et al., Proc. ODP, Init. Repts., 209: College Station, TX (Ocean Drilling Program), 1129. doi:10.2973/odp.proc.ir.209.106.2004

Teagle, D.A.H., Ildefonse, B., Blum, P., and the Expedition 335 Scientists, 2012. Proc. IODP, 335: Tokyo (Integrated Ocean Drilling Program Management International, Inc.). doi:10.2204/iodp.proc.335.2012

Publication: 12 February 2014 MS 345-113 
Figure F1. A. Core recovery and principal lithologies, Hole U1415P. B-D. Recovered rock types. E. Rock types in all samples including ghost cores. F. Rock types in all cores excluding ghost cores. $\mathrm{Ol}=$ olivine, opx $=$ orthopyroxene.

A Hole U1415P

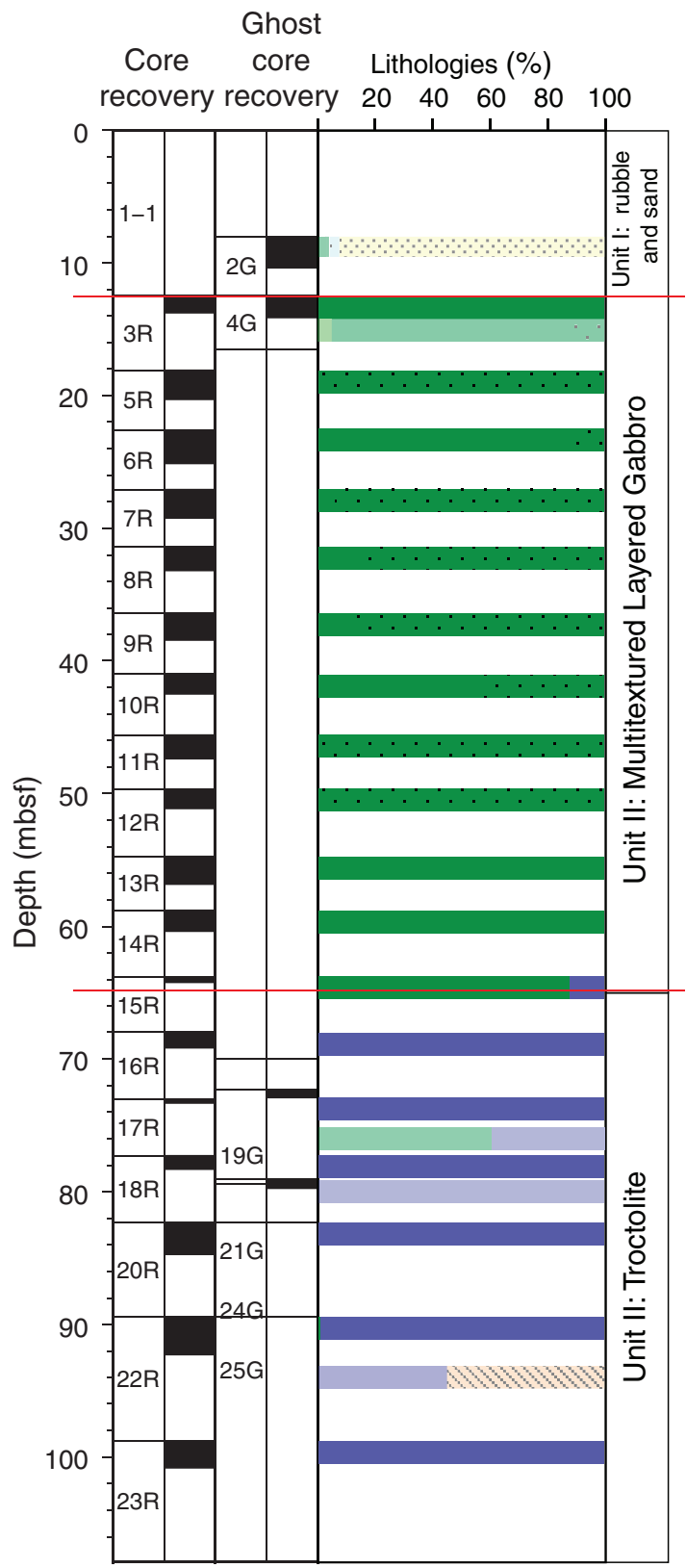

108.1 mbsf bottom depth $95.4 \mathrm{~m}$ cored interval

$30.6 \mathrm{~m}$ recovered interval $32 \%$ recovery

\begin{tabular}{lll}
\hline Gabbro & Basalt \\
Ol gabbro & $\begin{array}{l}\text { Drilling-induced } \\
\text { disaggregated } \\
\text { troctolite }\end{array}$ \\
$\begin{array}{l}\text { Ol gabbro } \\
\text { (opx-bearing) }\end{array}$ & Sand \\
Troctolite & S:
\end{tabular}

B Ghost (Cores 2G, 4G, 19G, 21G, 25G)

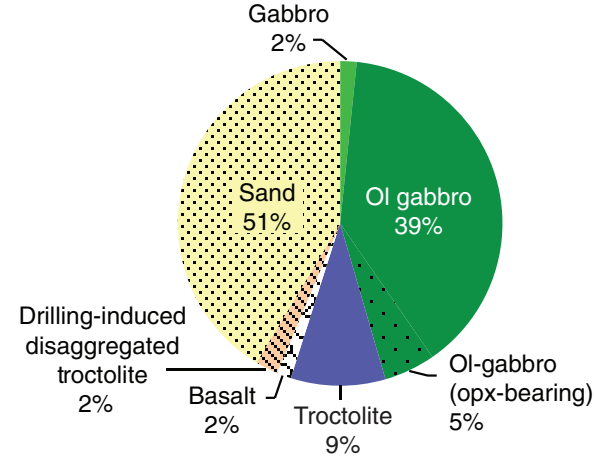

C Unit II (Cores 3R, 5R-15R, $39 \mathrm{~cm}$ )

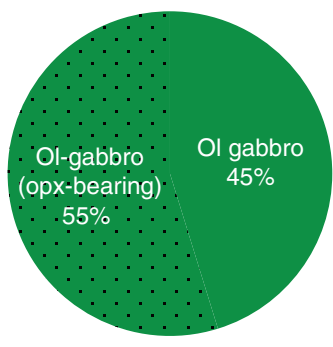

D Unit III (Cores 15R, $39 \mathrm{~cm}$, through 18R, 20R,

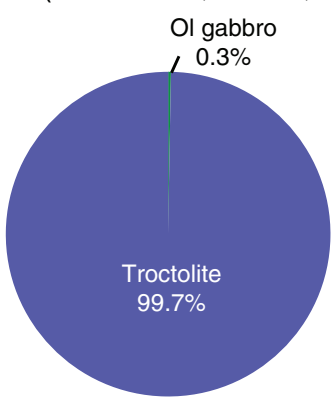

E All samples

Drilling-induced

disaggregated
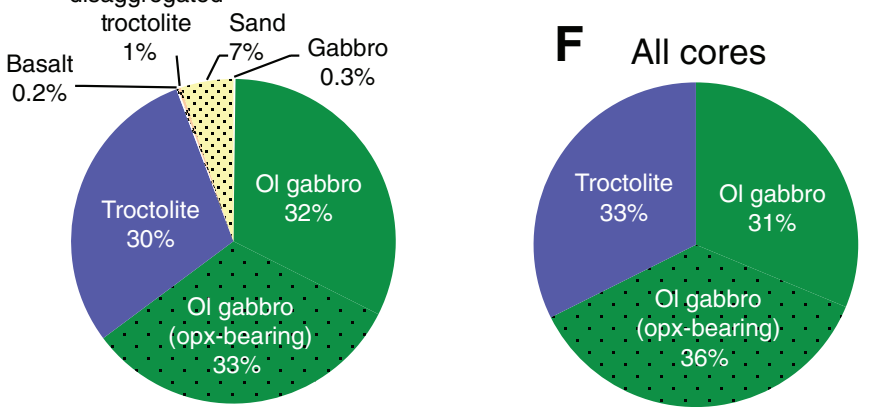
Figure F2. Stratigraphic variations of modal composition and grain size of minerals in Units II and III (Cores 345-U1415P-3R through 23R; ghost cores not included) based on visual core description. Grain size: black lines = mode, blue diamonds = maximum. Some of the plagioclase (Plg) for which a coarse grain size $(\sim 10 \mathrm{~mm})$ was macroscopically estimated in rock of Unit II actually represent aggregates of much finer grained plagioclase crystals (average size $=\sim 0.3 \mathrm{~mm}$ ). In Unit II, very coarse grained clinopyroxene $(\mathrm{Cpx})$ grains were observed. Microscopic examination of these clinopyroxenes confirmed that they are large optically continuous poikilitic grains. In Unit III, clinopyroxene is a minor interstitial component and very small grain sizes were visually estimated. However, under microscopic examination, many of the interstitial grains are actually parts of centimeter-sized optically continuous clinopyroxenes. $\mathrm{Ol}=$ olivine, $\mathrm{Opx}=$ orthopyroxene, OXs = oxides.
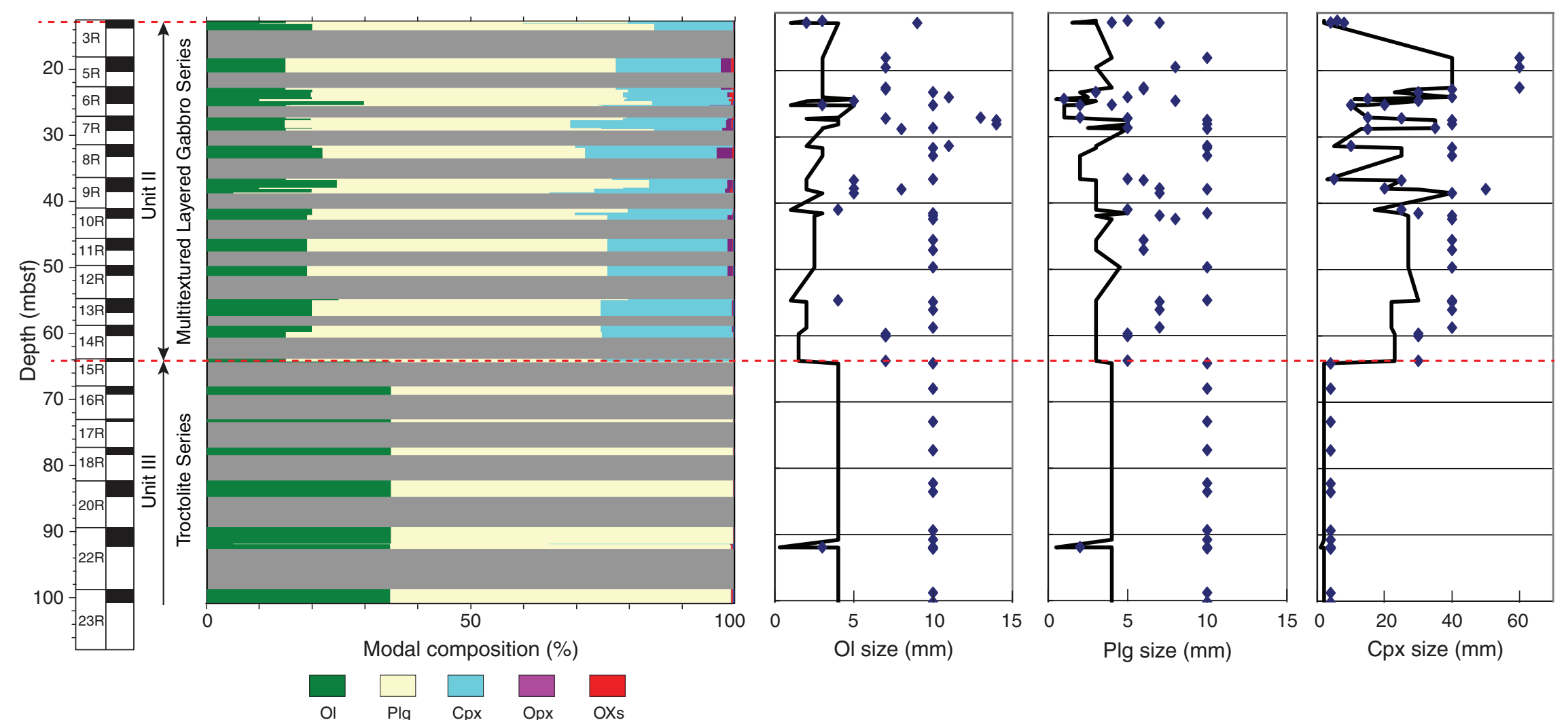
Figure F3. Multitextured olivine $(\mathrm{Ol})$ gabbro in Intervals 4-8. Cpx = clinopyroxene, $\mathrm{Pl}=$ plagioclase. A, B. Section 345-U1415P-6R-1. (A) Dry image of full section. (B) Thin Section 106 (Sample 6R-1, 58-61 cm [Piece 6]; under crossed polars). C, D. Section 345-U1415P-6R-2. (C) Dry image of full section. (D) Thin Section 110 (Sample 6R-2, 90-91 cm [Piece 11]; under crossed polars). Note the presence of interstitial clinopyroxene forming centimeter-sized coherent crystals visible in B and D.

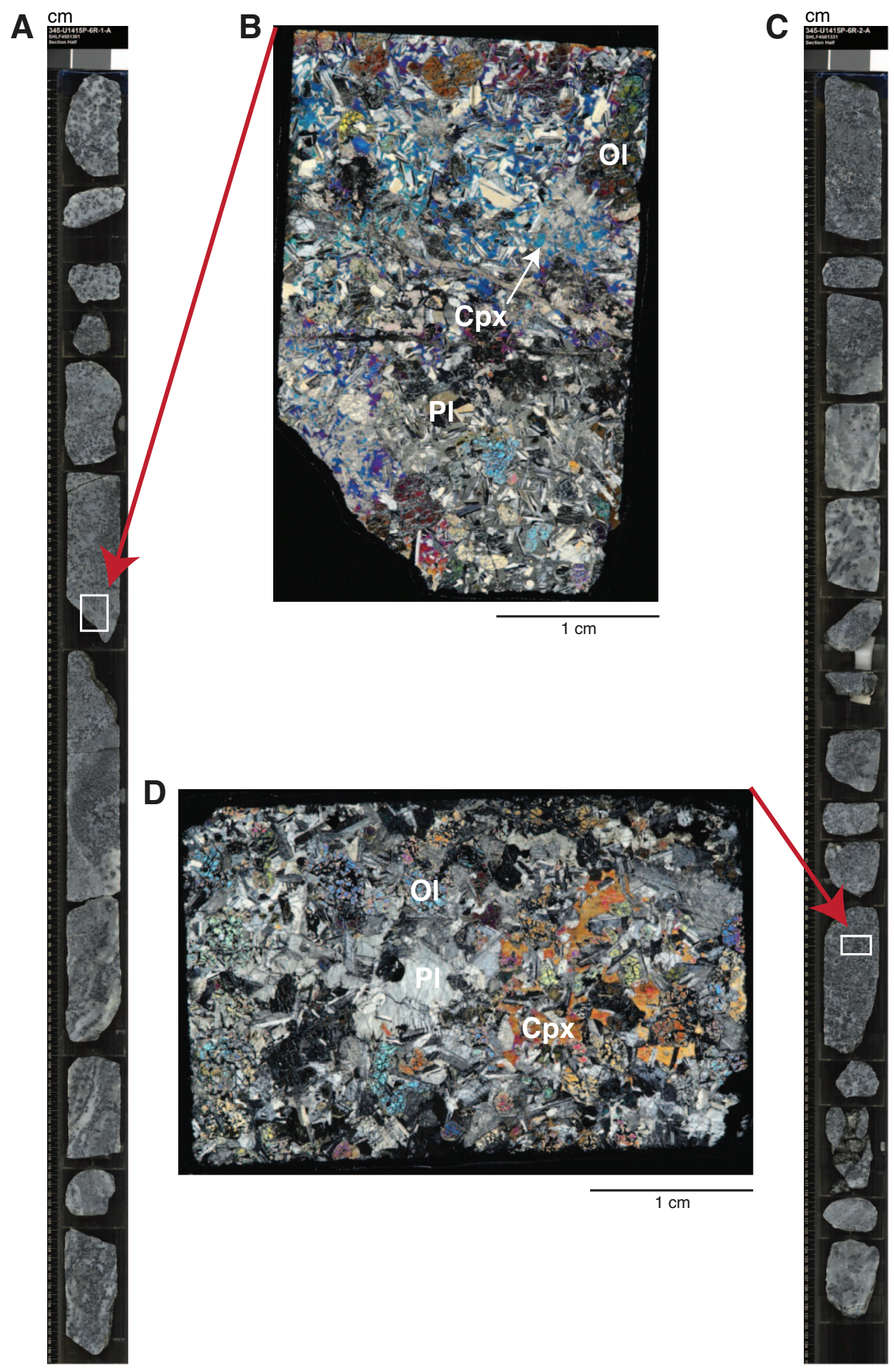


Figure F4. Typical appearance of homogeneous equigranular orthopyroxene (Opx)-bearing olivine (Ol) gabbro in Unit II (Multitextured Layered Gabbro Series). A. Sample 345-U1415P-9R-2, 12-33 cm (Pieces 3, 4). B, C. Patchy distribution of two different lithologic domains which are distinguished by the amount of orthopyroxene, 0 in the left domain and 5\% in the right domain, leading to the rock name "olivine gabbronorite" for the right domain (Thin Section 119; Sample 9R-2, 20-21 cm [Piece 3]). Cpx = clinopyroxene, $\mathrm{Pl}=$ plagioclase. $\mathrm{B}$ is under plane-polarized light; $\mathrm{C}$ is under crossed polars.
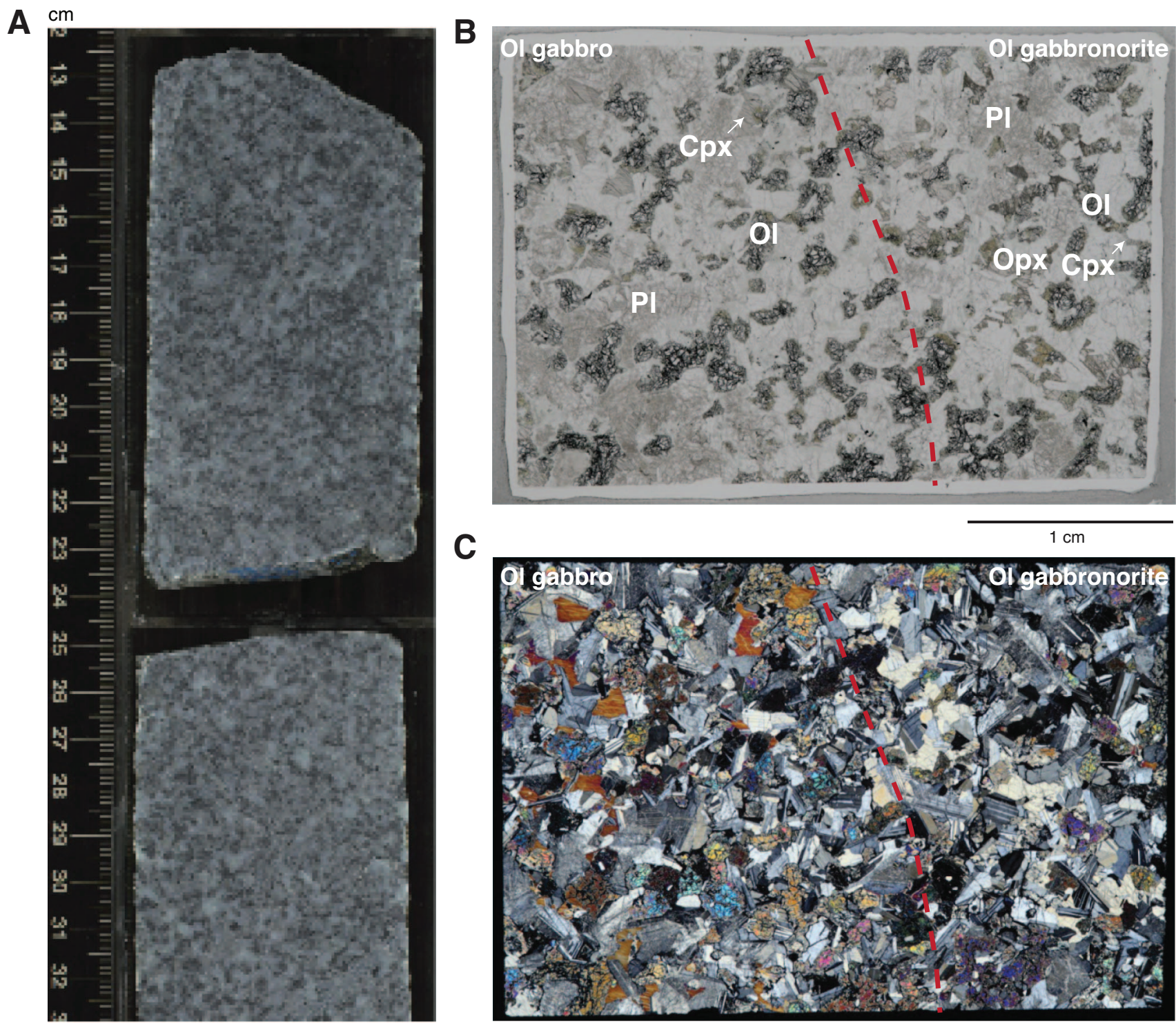

C

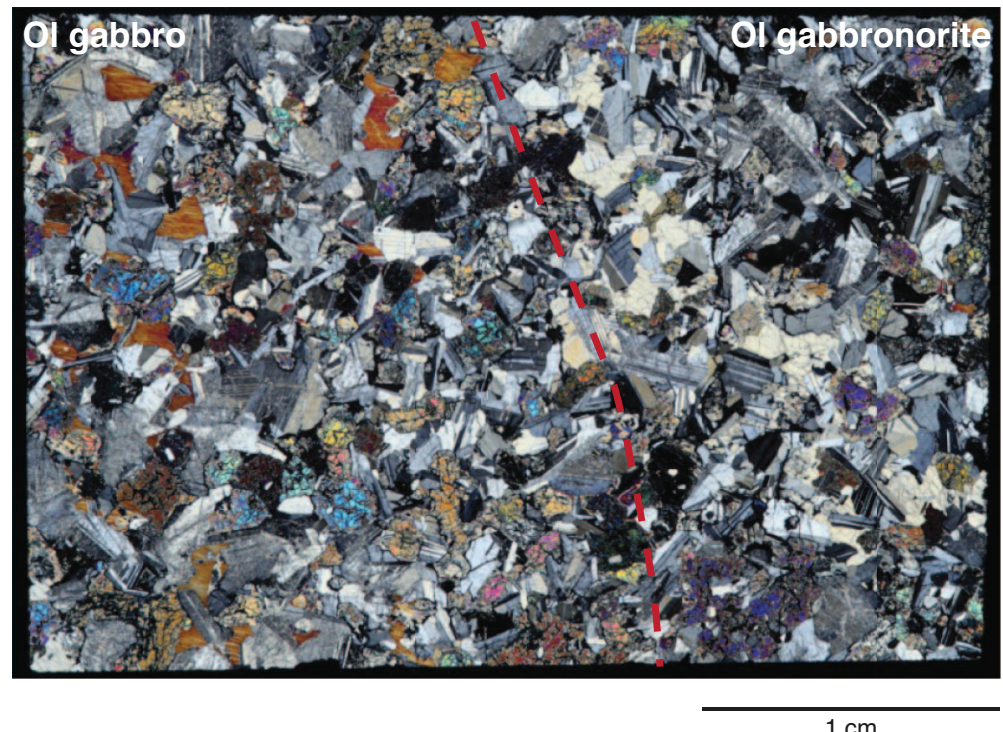


Figure F5. Typical appearance of troctolite in Unit III (Troctolite Series). Troctolite is, in general, equigranular with a granular texture showing a remarkable degree of homogeneity in both modal composition and grain size. Troctolite generally consists of olivine (30-54 vol\%) and plagioclase (45-70 vol\%), with trace amounts of clinopyroxene and oxide (Cr-spinel). A. Sample 345-U1415P-16R-1, 85-94 cm (Piece 9). B. Sample 345-U1415P20R-2, 3-12 cm (Piece 1).

A

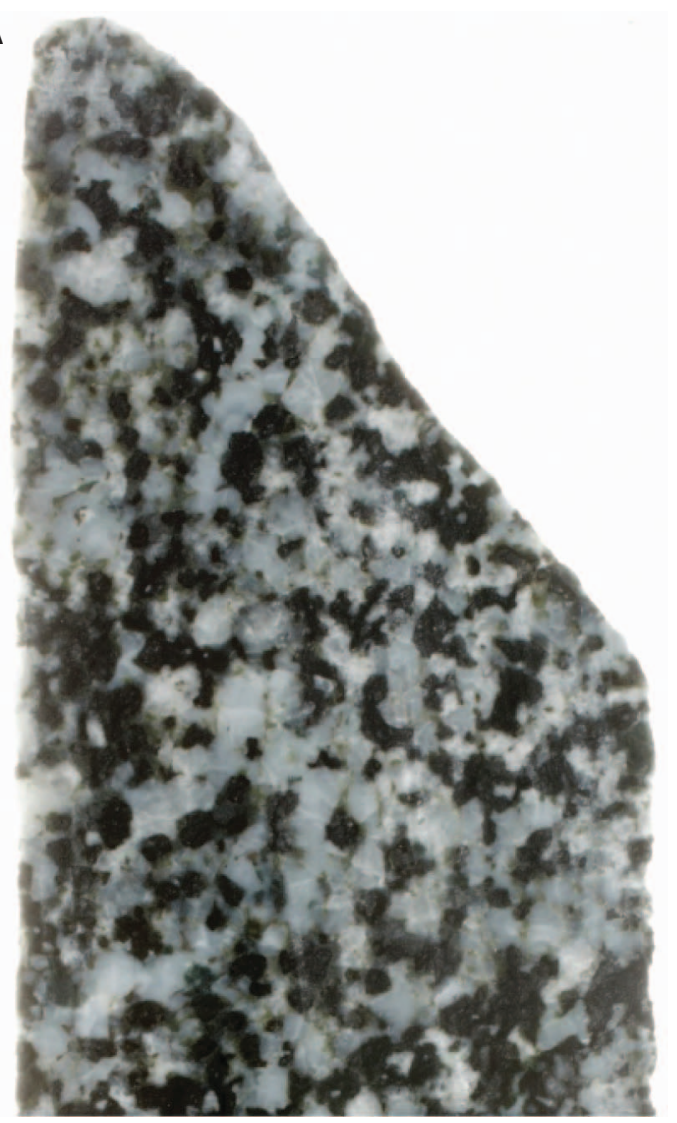

B

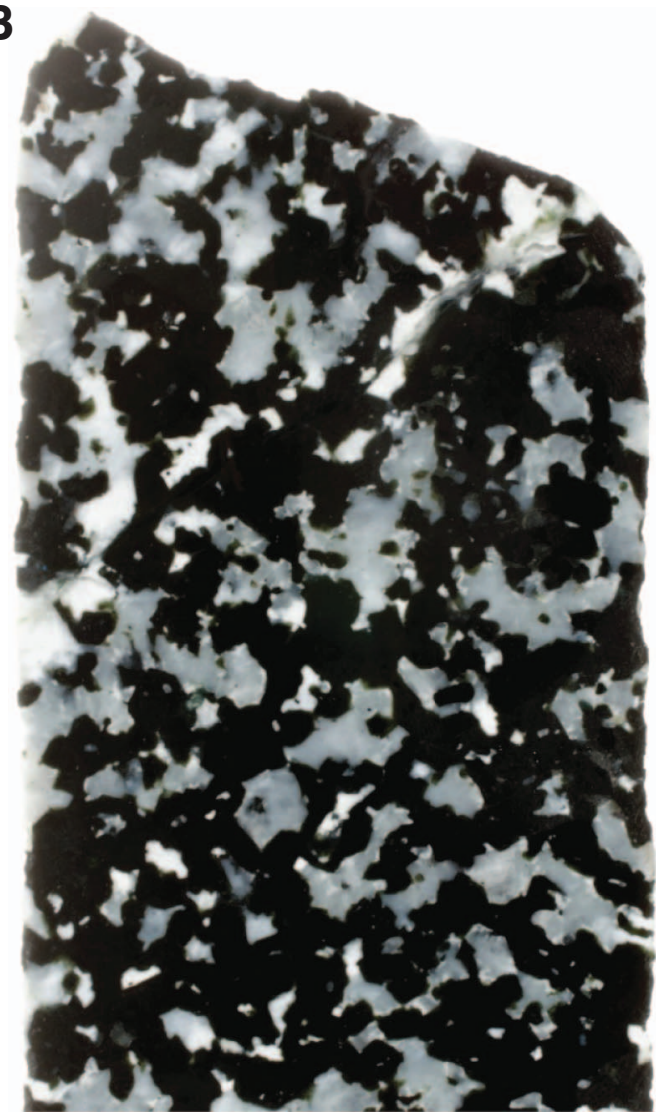

$2 \mathrm{~cm}$ 
Figure F6. Troctolite in Unit III (Troctolite Series) (Thin Section 133; Sample 345-U1415P-18R-1, 39-40 cm [Piece 6]). Troctolite in Unit III is typically equigranular with granular texture. Note that the thin section contains only two optically continuous grains of interstitial clinopyroxene (Cpx). A. Plane-polarized light. $\mathrm{Ol}=\mathrm{ol}-$ ivine, $\mathrm{Pl}=$ plagioclase, $\mathrm{Cpx}=$ clinopyroxene. $\mathbf{B}$. Under crossed polars.
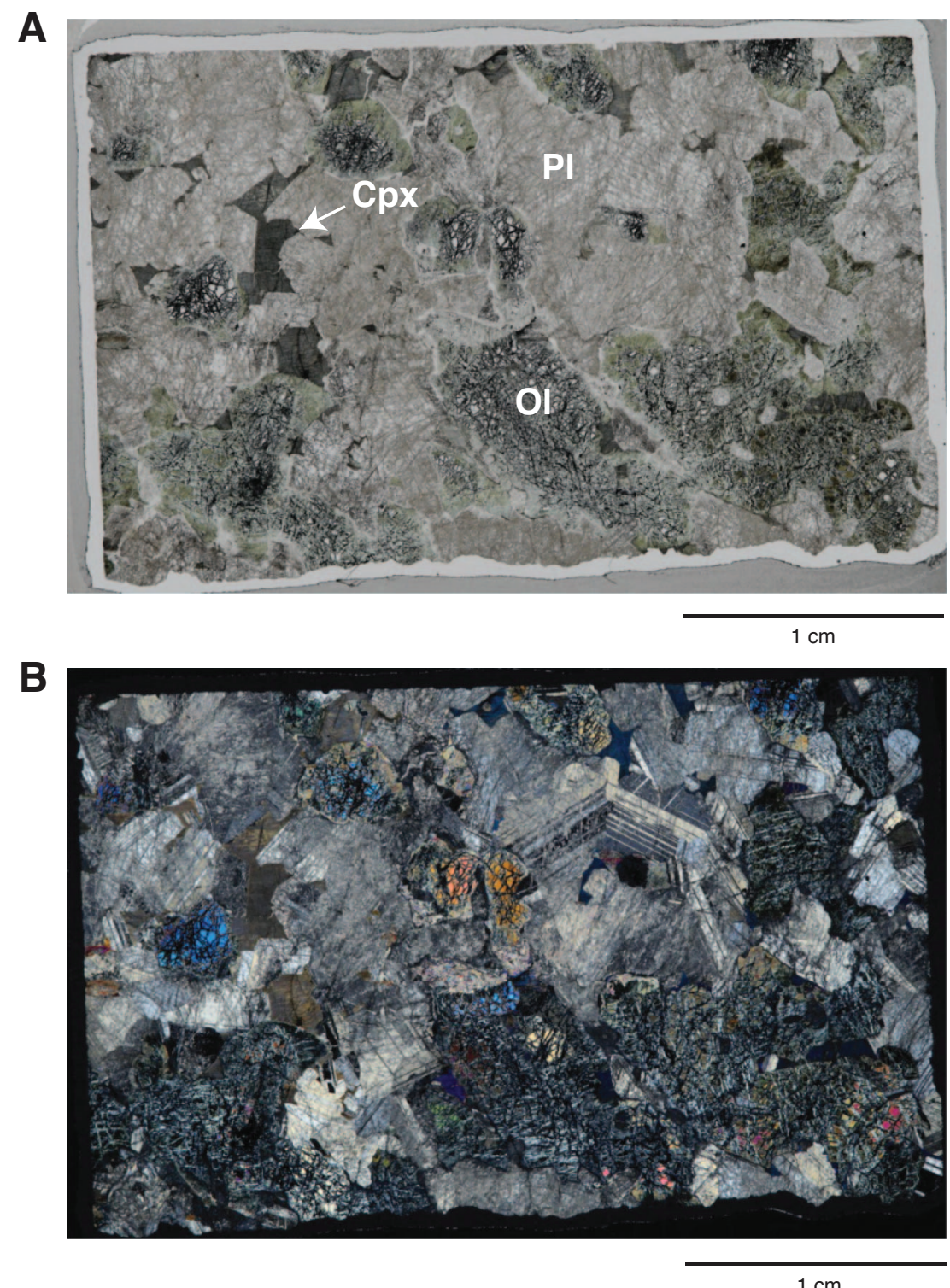
Figure F7. Multitextured olivine gabbro in Unit II (Sample 345-U1415P-7R-2, 10-54 cm [Piece 2]; Interval 13). A patch of medium-grained orthopyroxene-bearing olivine gabbro with diffuse boundaries in pegmatitic olivine gabbro is interpreted as an enclave (red dashed line). A. Wet image. B. Dry image.

A

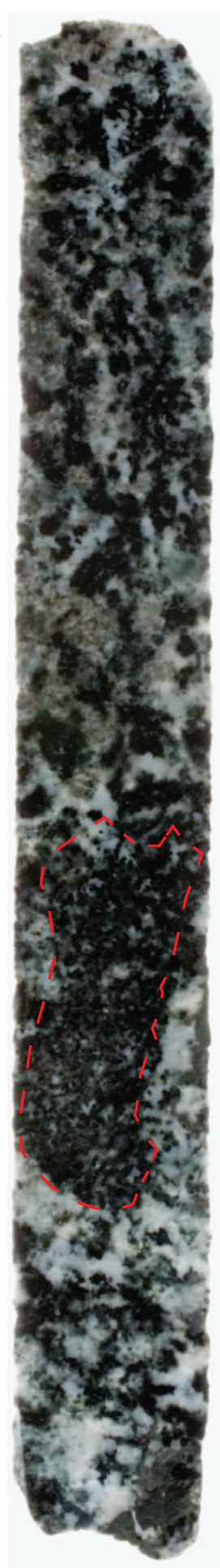

B

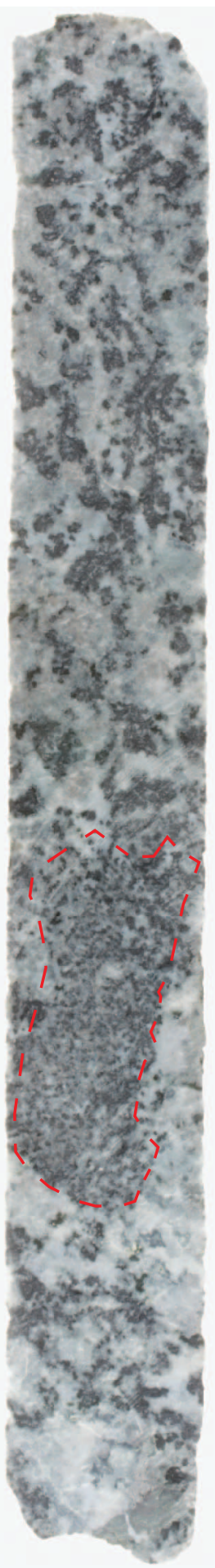

$2 \mathrm{~cm}$ 
Figure F8. Multitextured orthopyroxene (Opx)-bearing olivine gabbro in Unit II (Sample 345-U1415P-8R-1, 79$90 \mathrm{~cm}$ [Piece 6]; Interval 17). Visible bands consist mainly of orthopyroxene (arrows). A. Wet image. B. Dry image.

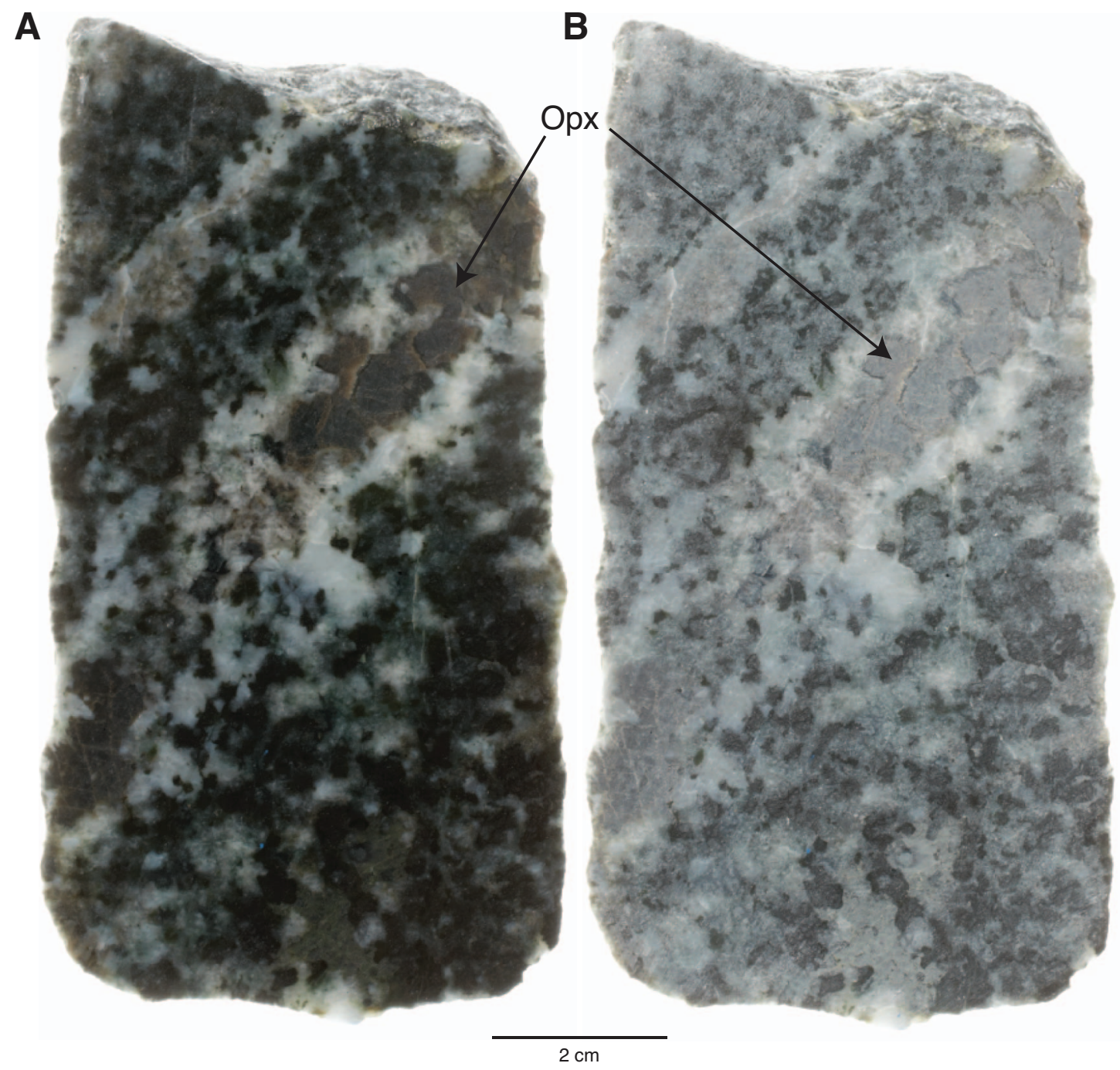


Figure F9. Multitextured olivine gabbro in Unit II (Sample 345-U1415P-4G-1, 62-93 cm [Piece 8]; Interval G16). Red dashed lines show pegmatitic patches with diffuse boundaries associated with olivine gabbro. The arrow indicates a centimeter-sized pegmatitic clinopyroxene crystal. A. Dry image. B. Wet image.

A

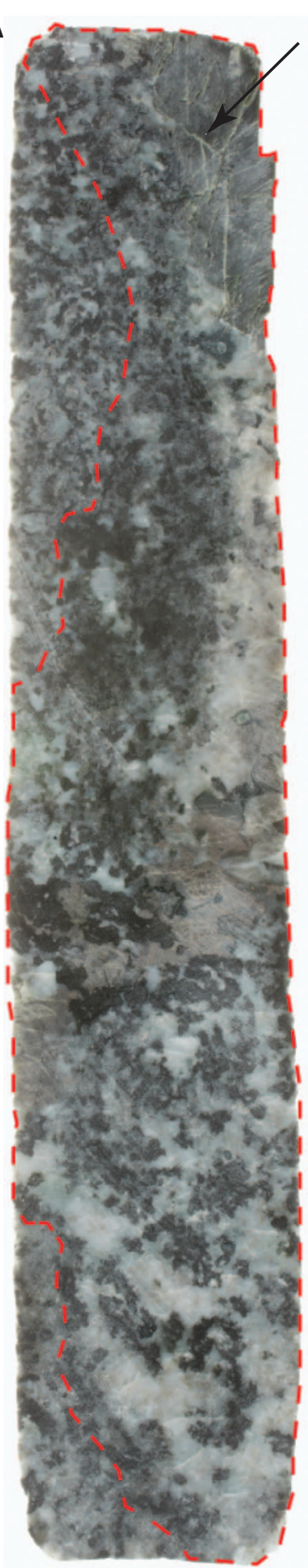

B

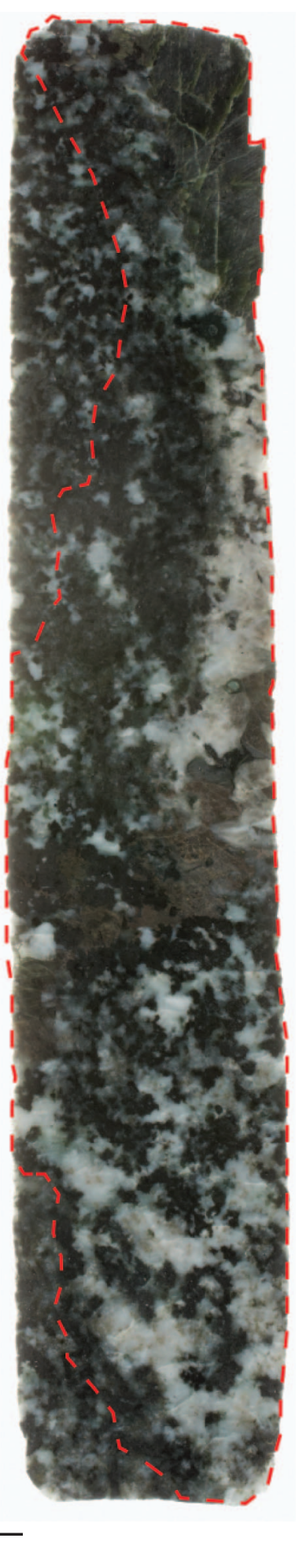


Figure F10. Multitextured olivine gabbro in Unit II (Sample 345-U1415P-6R-2, 44-54 cm [Piece 5]; Interval 7). The "black dots" (arrows in A) are Cr-spinel (Spl). Note the presence of skeletal olivine. A. Dry image. Ol = olivine, $\mathrm{Cpx}=$ clinopyroxene, $\mathrm{Pl}=$ plagioclase. $\mathbf{B}$. Wet image.

A

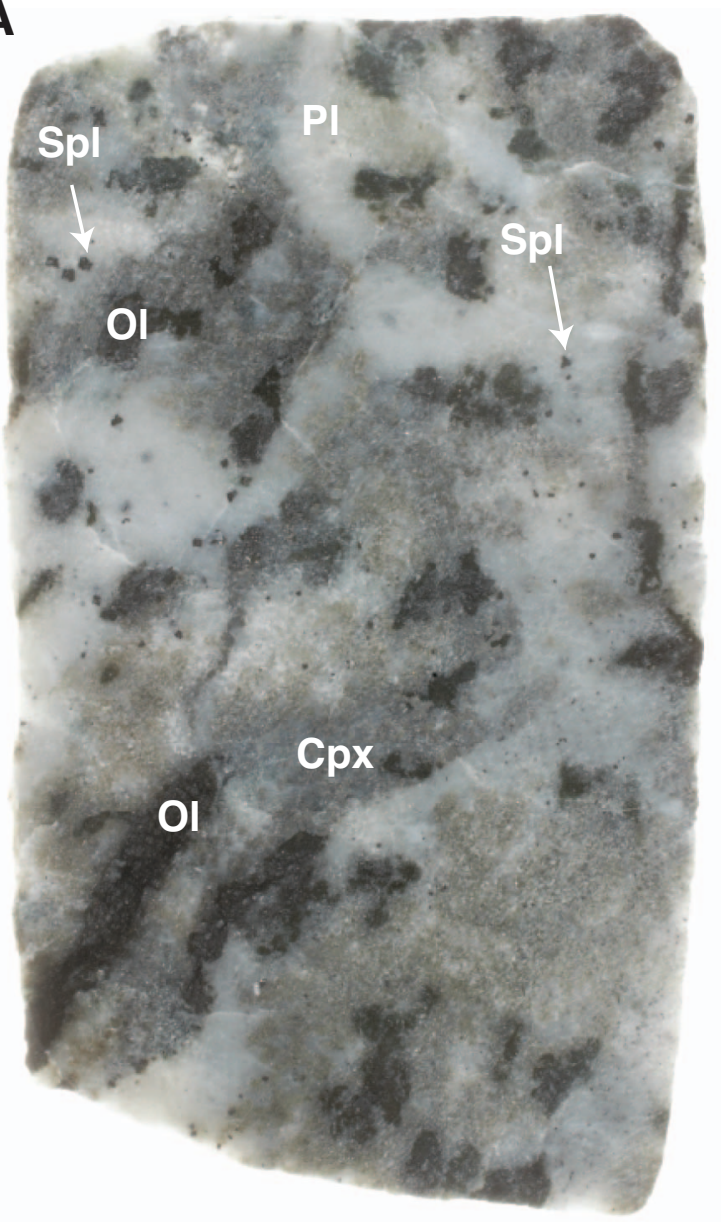

B

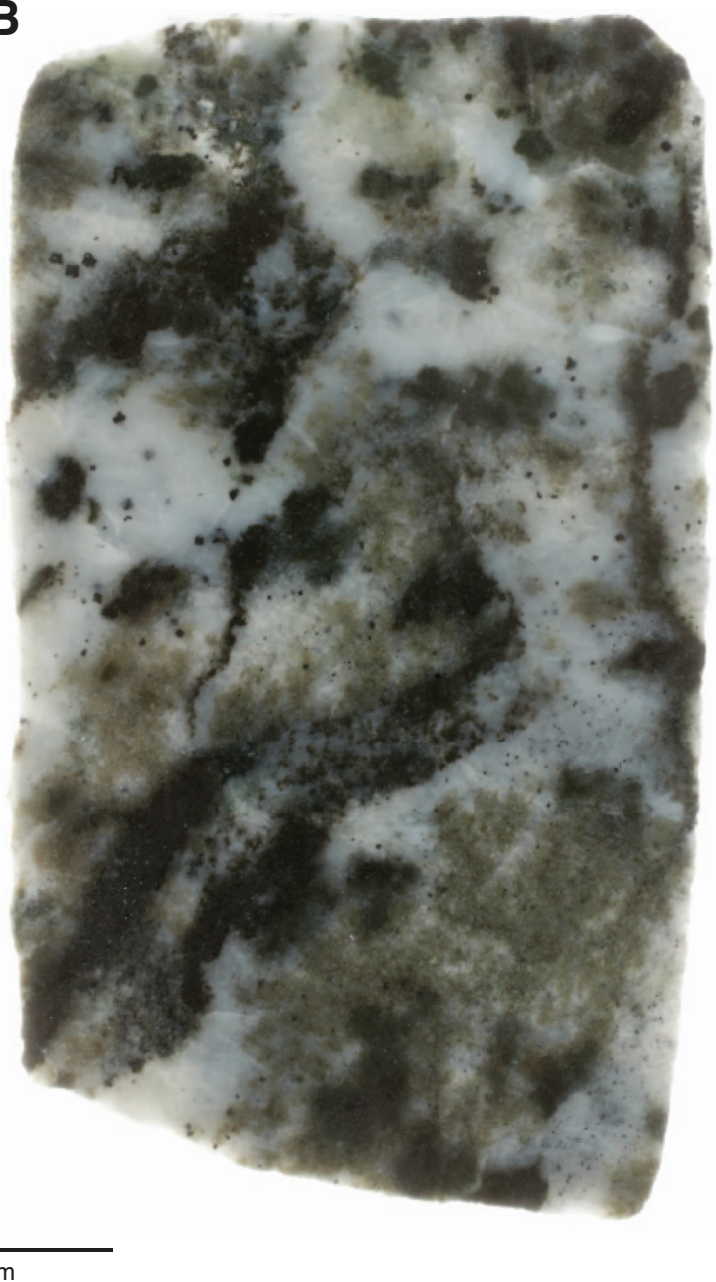


Figure F11. Multitextured orthopyroxene-bearing olivine gabbro in Unit II. Note vertical bands within heterogeneous olivine gabbro (Sample 345-U1415P-8R-2, 0-28 cm [Piece 1]; Interval 17). See text for explanation of (a) and (b) at the boundary of the band to the host rock. A. Dry image. B. Wet image.

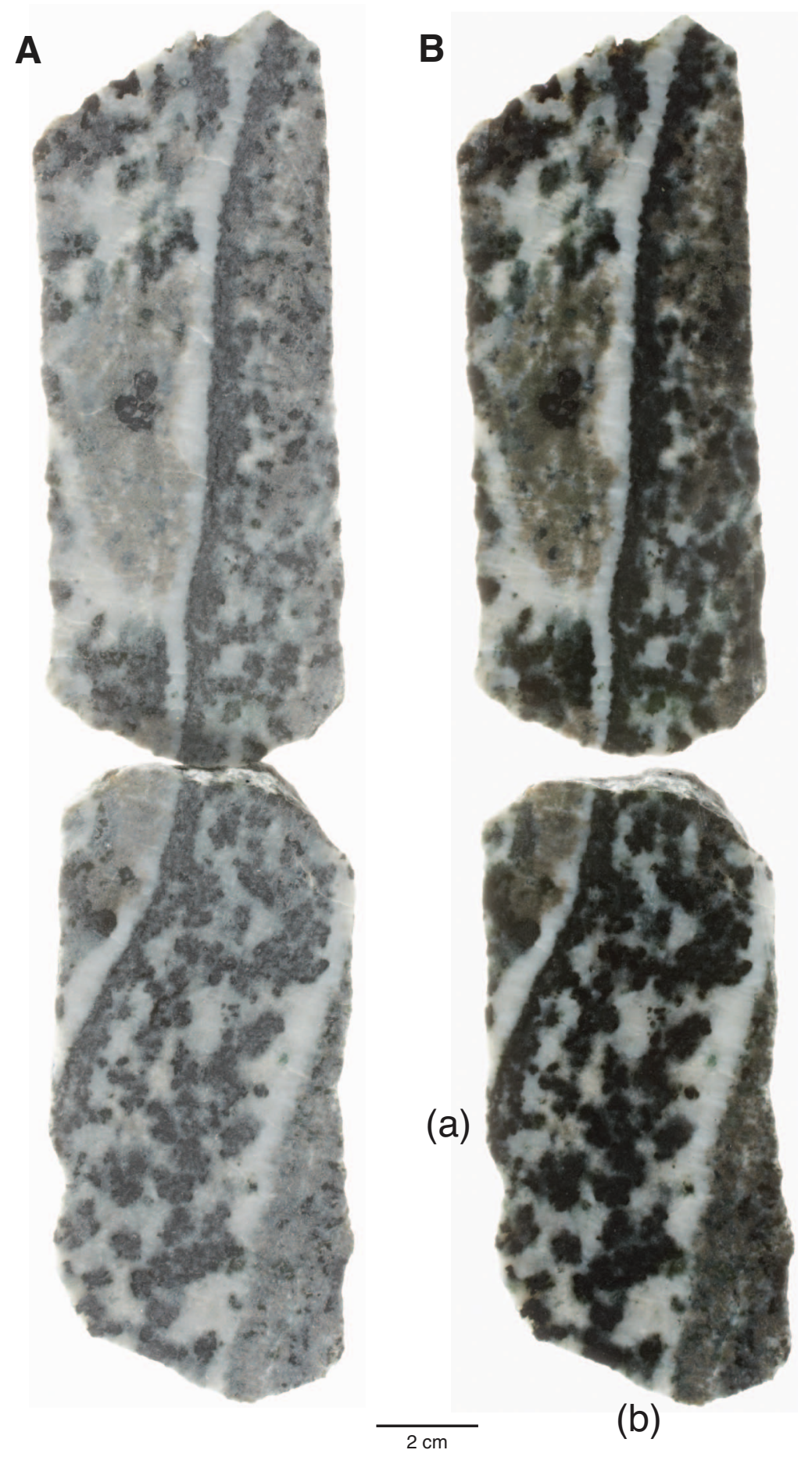


Figure F12. Boundary between olivine gabbro and orthopyroxene (Opx)-bearing troctolite interpreted as mafic enclave (red dashed lines). The olivine gabbro host rock is described as an "anorthosite domain" in thin section images because this part of the rock contains only plagioclase due to the heterogeneous distribution of large minerals in the olivine gabbro. Boundary type = grain size and modal; boundary definition $=$ sharp and sutured. For details see "Descriptions of igneous boundaries." A. Sample 345-U1415P-7R-2, 9.5-56 cm (Piece 2). Blue box indicates the position of thin section in B and C (Thin Section 114; Sample 345-U1415P-7R-2, 41-54 cm [Piece 2]). B. Plane-polarized light. $\mathrm{Ol}=$ olivine, $\mathrm{Cpx}=$ clinopyroxene, $\mathrm{Pl}=$ plagioclase . $\mathrm{C}$. Under crossed polars.

A

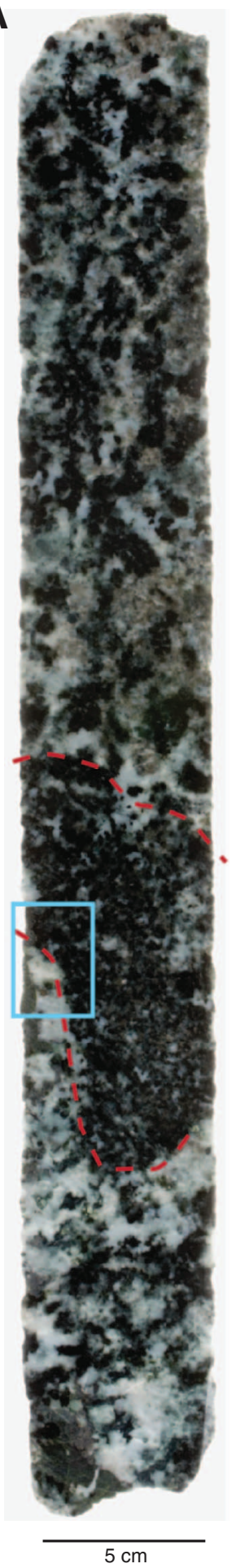

B

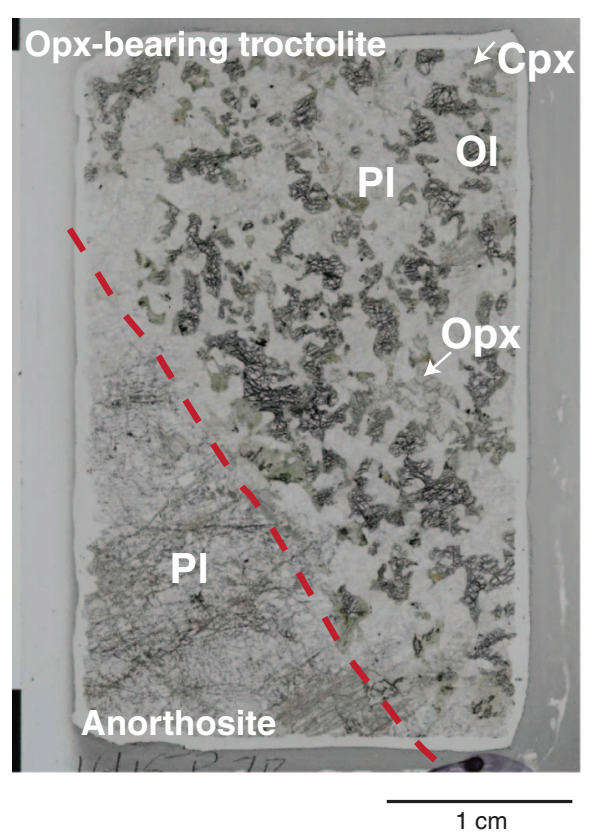

C

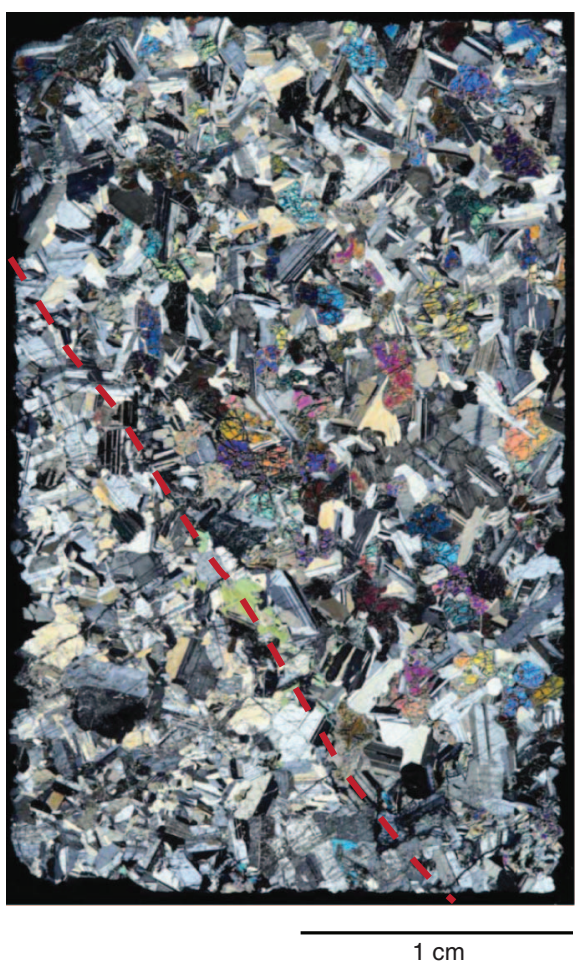


Figure F13. Boundary between gabbro and orthopyroxene (Opx)-bearing olivine (Ol) gabbro (red dashed lines) (Thin Section 127; Sample 345-U1415P-14R-1, 16-25.5 cm [Piece 3]). Boundary type = grain size and modal; boundary definition = sharp and sutured. For details see "Descriptions of igneous boundaries." A. Core closeup. Blue box indicates the position of thin section in B and C. B. Plane-polarized light. Cpx = clinopyroxene, $\mathrm{Pl}=$ plagioclase. $\mathbf{C}$. Under crossed polars.
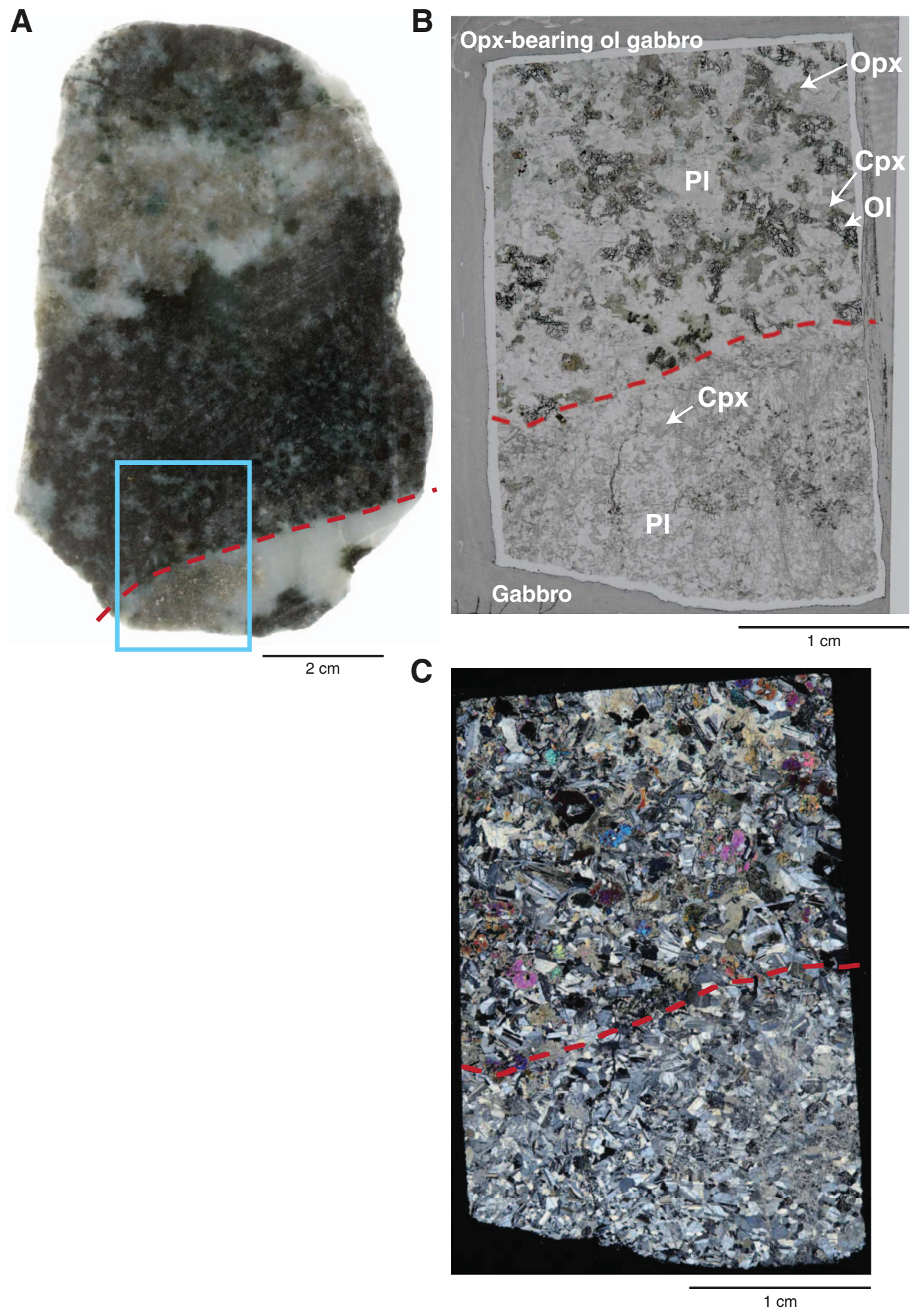
Figure F14. Boundary between anorthositic troctolite and orthopyroxene (Opx)-bearing olivine (Ol) gabbro (red dashed lines) (Thin Section 134; Sample 345-U1415P-18R-1, 78-83.5 cm [Piece 7]). Boundary type = grain size and modal; boundary definition = sharp and sutured. For details see "Descriptions of igneous boundaries." A. Core close-up. Blue box indicates the position of thin section in B and C. B. Plane-polarized light. $\mathrm{Cpx}=$ clinopyroxene, $\mathrm{Pl}=$ plagioclase . C. Under crossed polars .

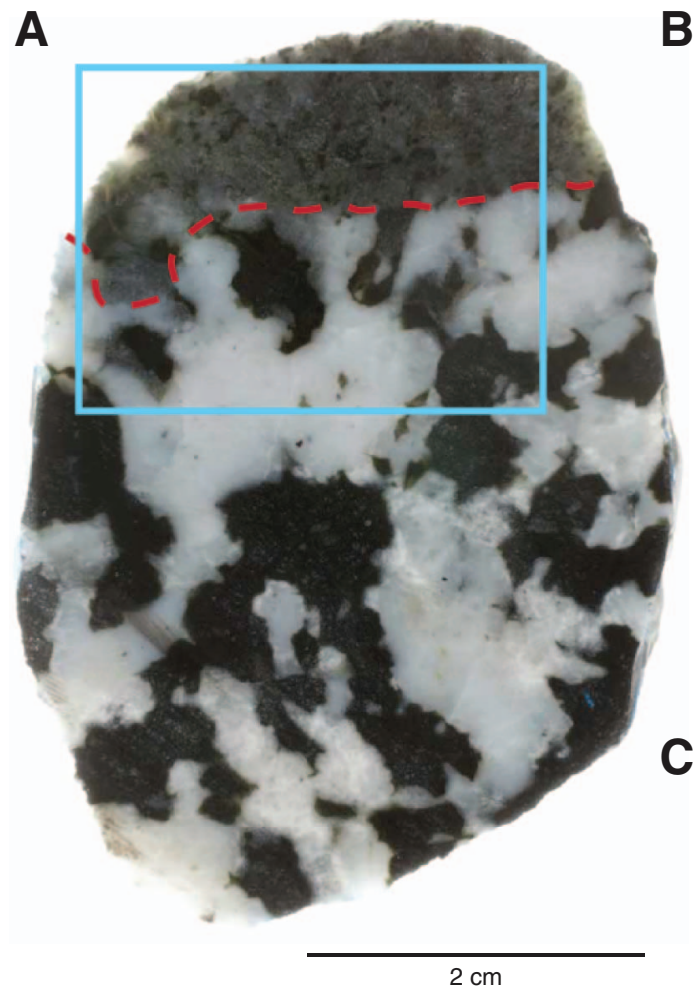

B

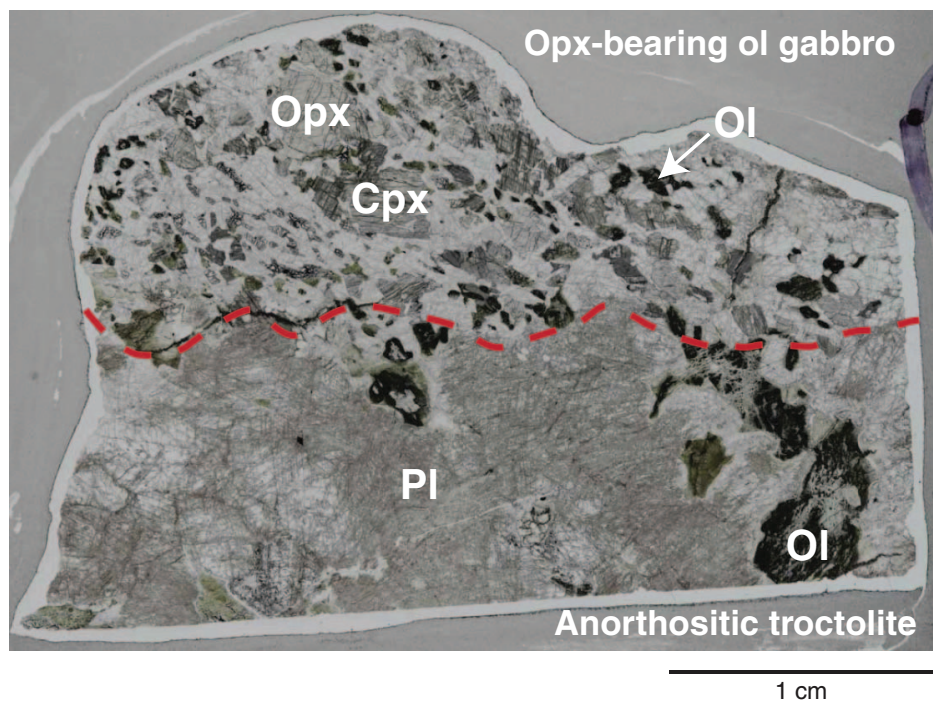

\section{列}

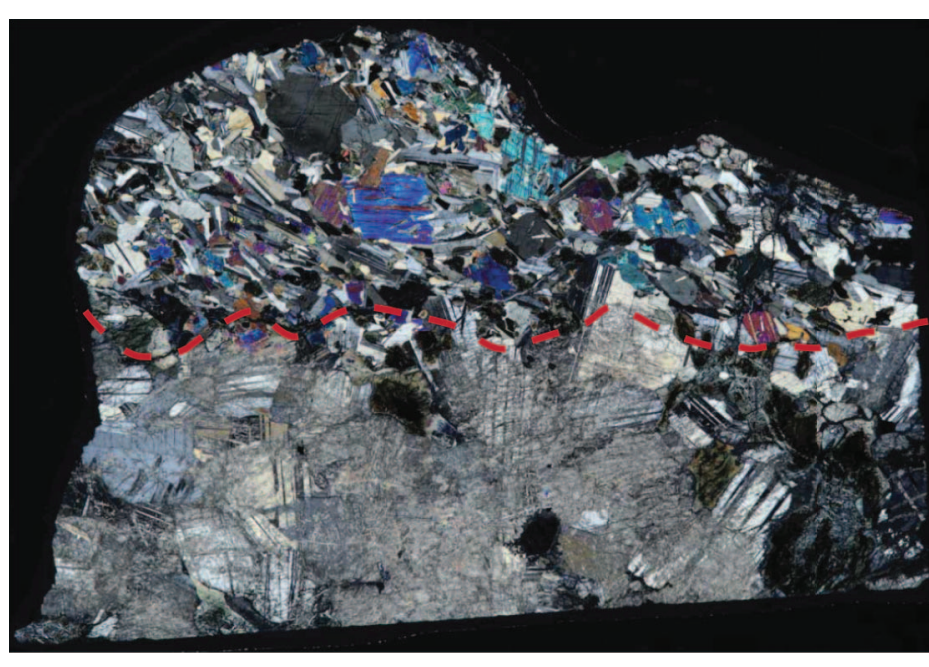

$1 \mathrm{~cm}$ 
Figure F15. Boundary between olivine (Ol) gabbro and troctolite (red dashed lines) (Thin Section 140; Sample 345-U1415P-22R-2, 99-115.5 cm [Piece 8]). Boundary type = grain size and modal; boundary definition = sharp and sutured. For details see "Descriptions of igneous boundaries." A. Core close-up. Blue box indicates the position of thin section in B and C. B. Plane-polarized light. Cpx = clinopyroxene, $\mathrm{Pl}=$ plagioclase. $\mathrm{C}$. Under crossed polars.

A

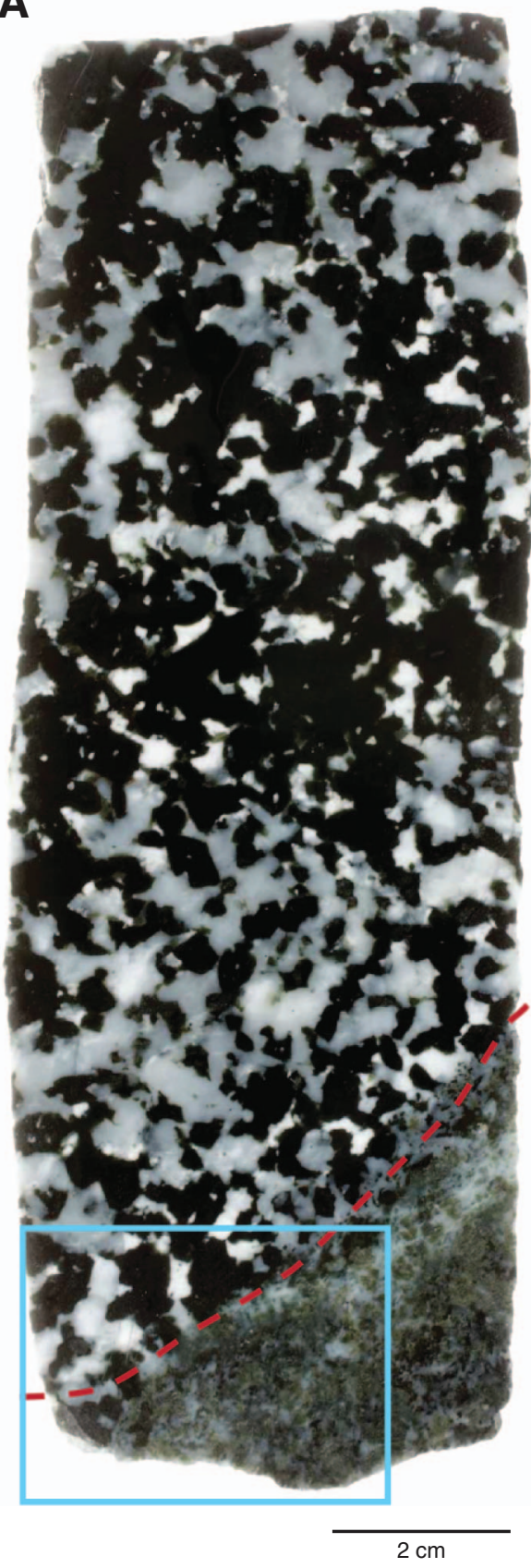

B

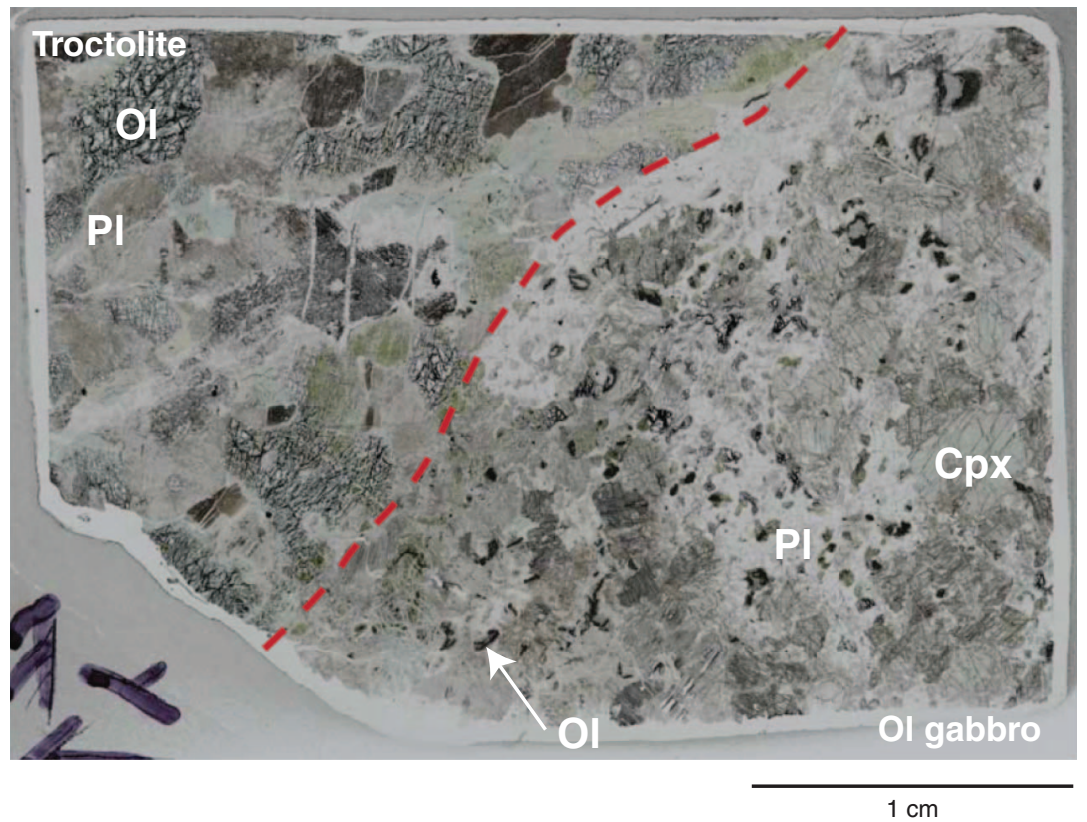

C

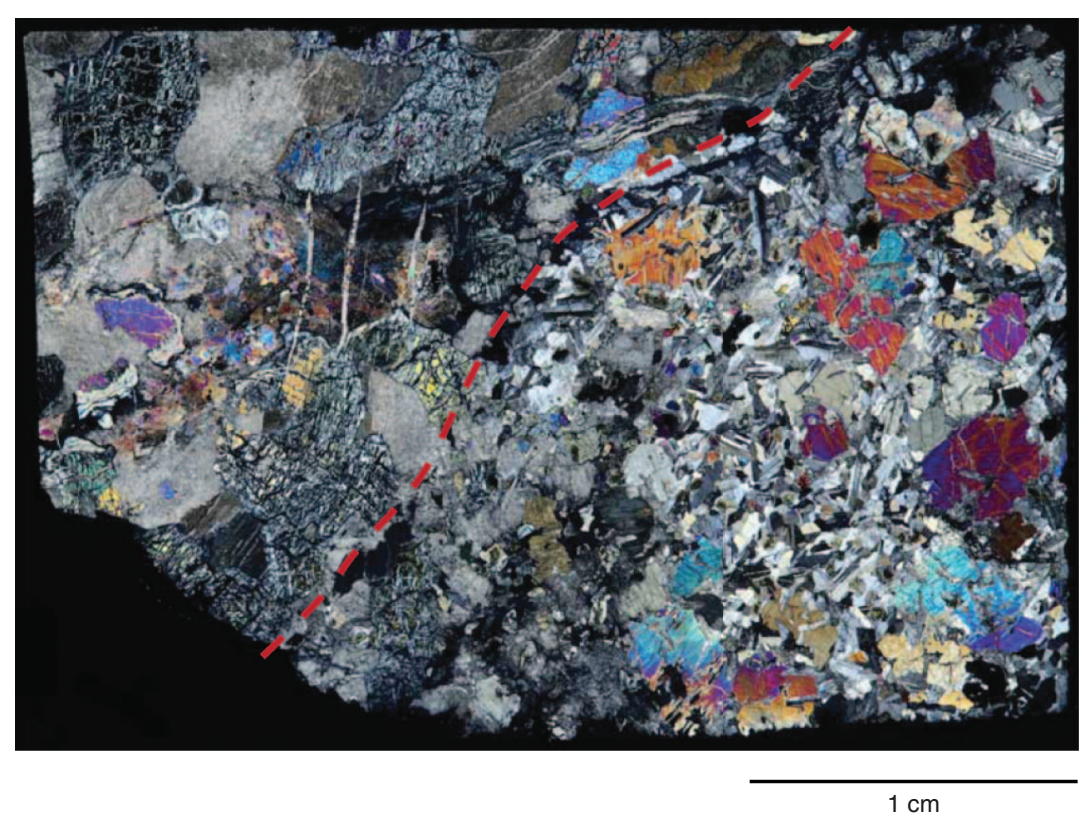


Figure F16. Core pieces with ubiquitous skeletal olivine; the arrows point to some exceptional examples. For details see text. A. Sample 345-U1415P-7R-1, 100-125 cm (Piece 11A). B. Sample 345-U1415P-7R-2, 9-30 cm (Piece 2). C. Sample 345-U1415P-8R-1, 133-146 cm (Piece 9). D. Sample 345-U1415P-9R-1, 29-42 cm (Piece 3). E. Sample 345-U1415P-10R-1, 56-69 cm (Piece 7). F. Sample 345-U1415P-10R-1, 69-82 cm (Piece 8). G. Sample 345-U1415P-13R-1, 46-59 cm (Piece 6). H. Sample 345-U1415P-13R-2, 41-51 cm (Piece 5).
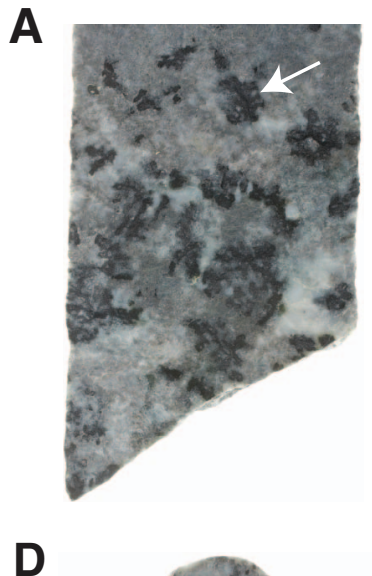

D

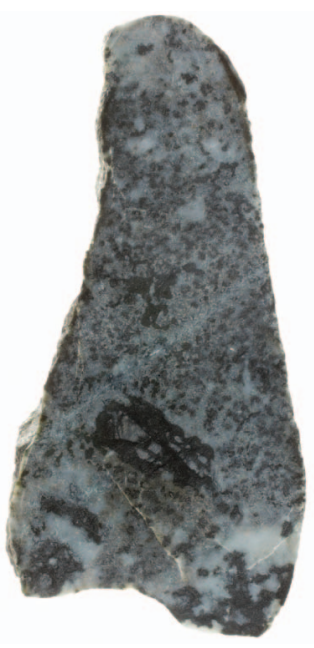

G

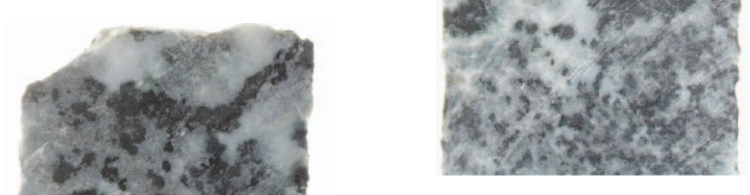

E

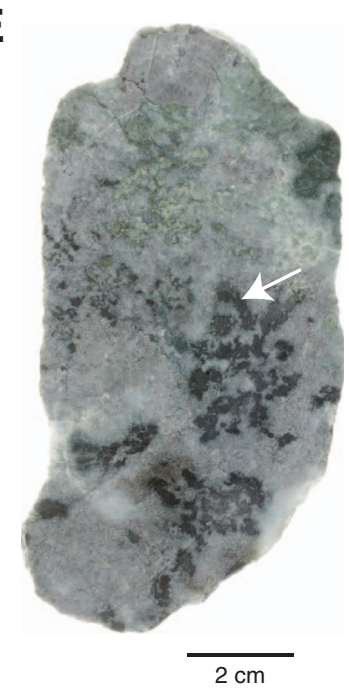

C

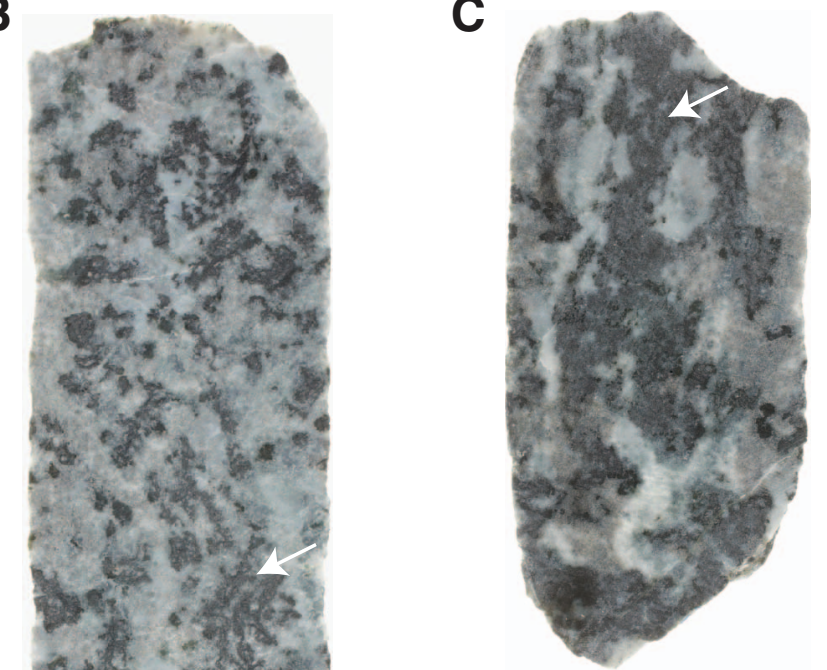

F

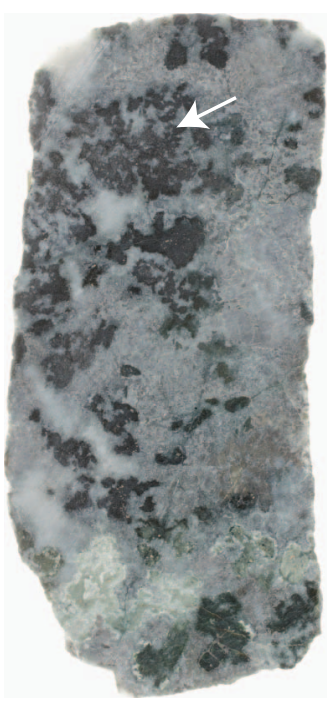

H

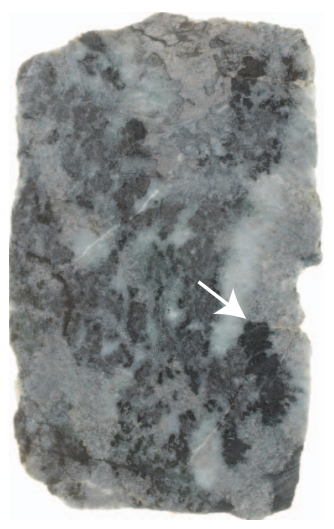


Figure F17. Downhole intensity of alteration of igneous minerals based on macroscopic descriptions, Hole U1415P. Ol = olivine, Opx $=$ orthopyroxene.
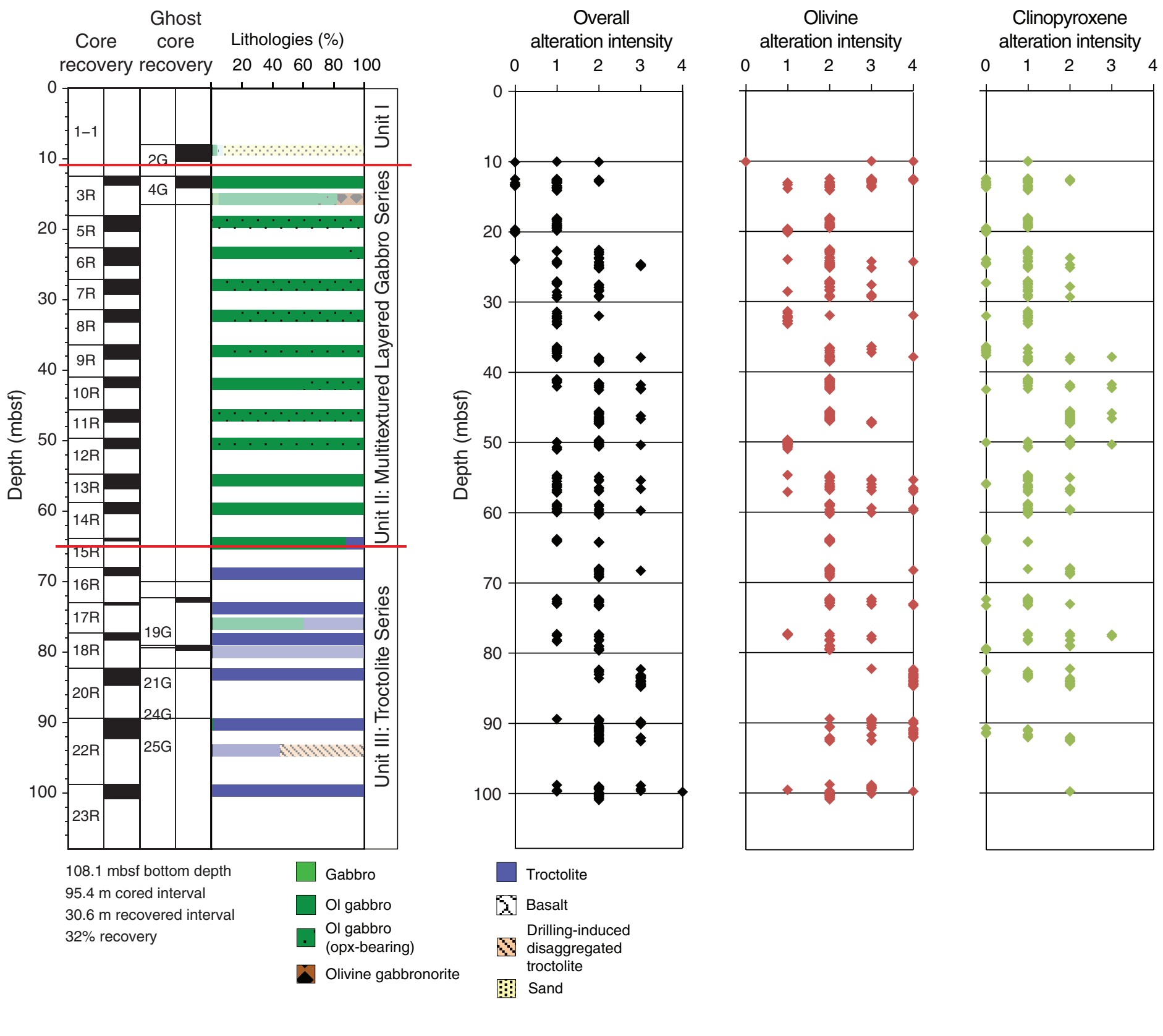

Plagioclase alteration intensity

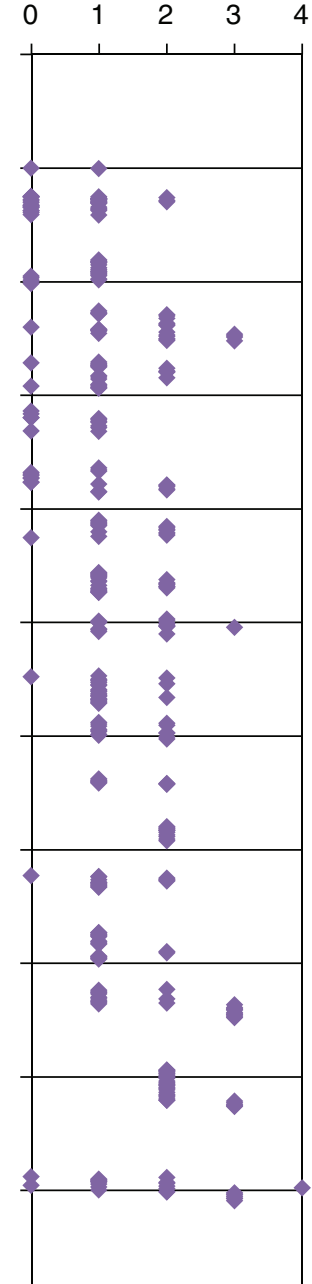


Figure F18. Olivine $(\mathrm{Ol})$ alteration at an igneous contact between troctolite and anorthosite (Thin Section 114; Sample 345-U1415P-7R-2, 41-44 cm). The replacement of olivine by clay minerals is intense at the contact. Pl = plagioclase. A. Plane-polarized light. B. Under crossed polars.
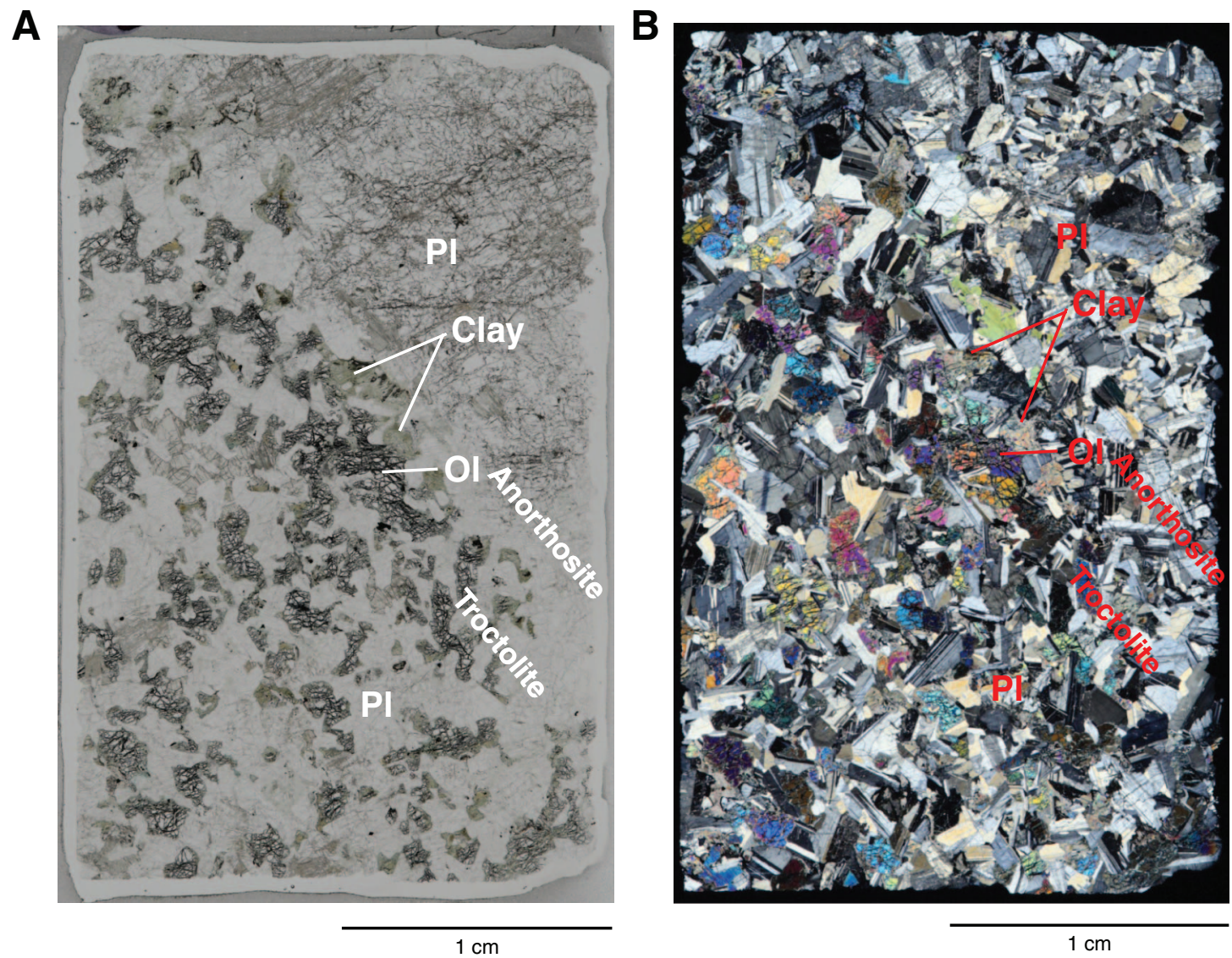
Figure F19. Olivine $(\mathrm{Ol})$ alteration intensity showing an increase in the percentage of olivine alteration and the relative abundance of serpentine to amphibole with depth, Hole U1415P. Downhole changes generally correlate with the boundary between lithologic Units II and III. Opx = orthopyroxene.
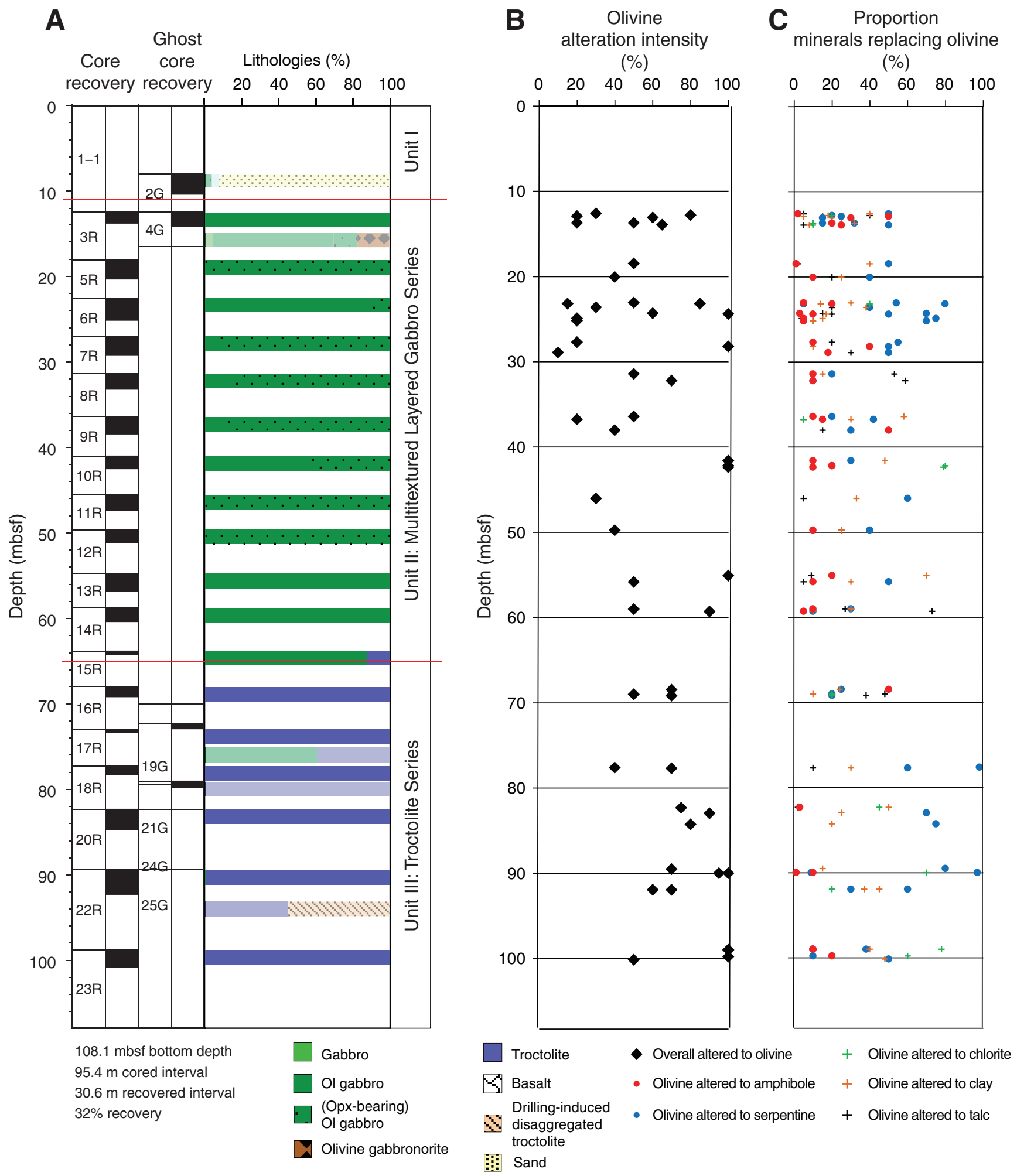
Figure F20. Localized formation of tremolite $(\mathrm{Tr})$, chlorite $(\mathrm{Chl})$, and talc $(\mathrm{Tc})$ between olivine $(\mathrm{Ol})$ and plagioclase (Pl) (Thin Section 97; Sample 345-U1415P-3R-1, 120-123 cm). This coronitic assemblage occurs locally within samples and is commonly distributed heterogeneously across individual olivine grains. Much of the olivine in this photomicrograph lacks the coronitic assemblage. Srp $=$ serpentine. A. Plane-polarized light. B. Under crossed polars.

A

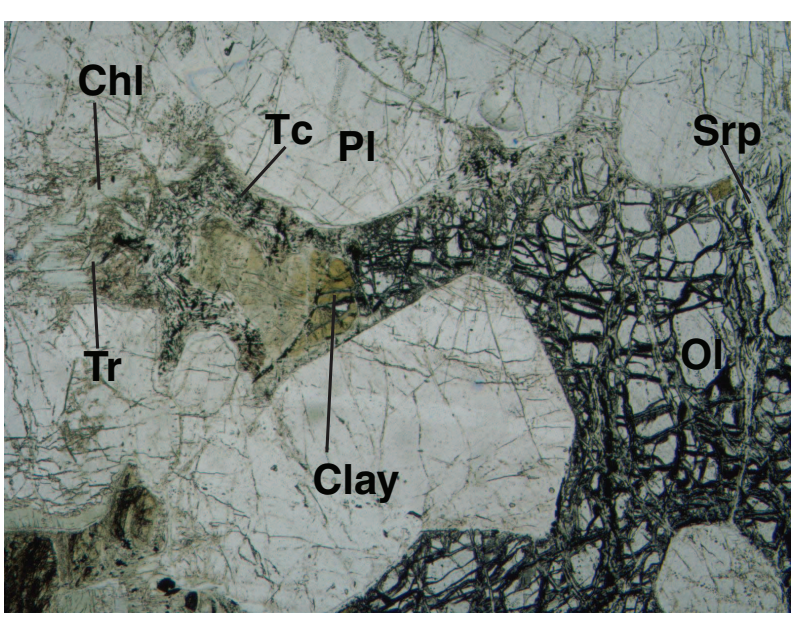

$1 \mathrm{~mm}$
B

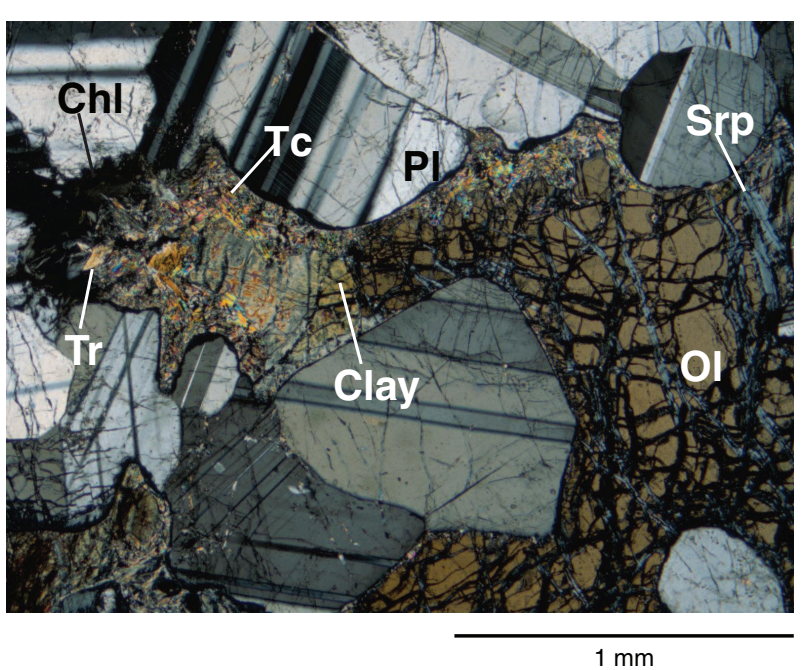


Figure F21. Example of the crosscutting relationship between talc (Tc), serpentine (Srp), and clay minerals replacing olivine (Ol) in olivine gabbro (Thin Section 97; Sample 345-U1415P-3R-1, 120-123 cm). Serpentine fills fracture in an olivine grain to form mesh texture. The serpentine mesh is visible in the clay-mineral domain but is absent in talc-rich domains in this slide. Dominant opaque mineral is possibly magnetite and pyrite in serpentine veinlets and clay/talc matrix, respectively. $\mathrm{Pl}=$ plagioclase. A. Plane-polarized light. $\mathbf{B}$. Under crossed polars.

A

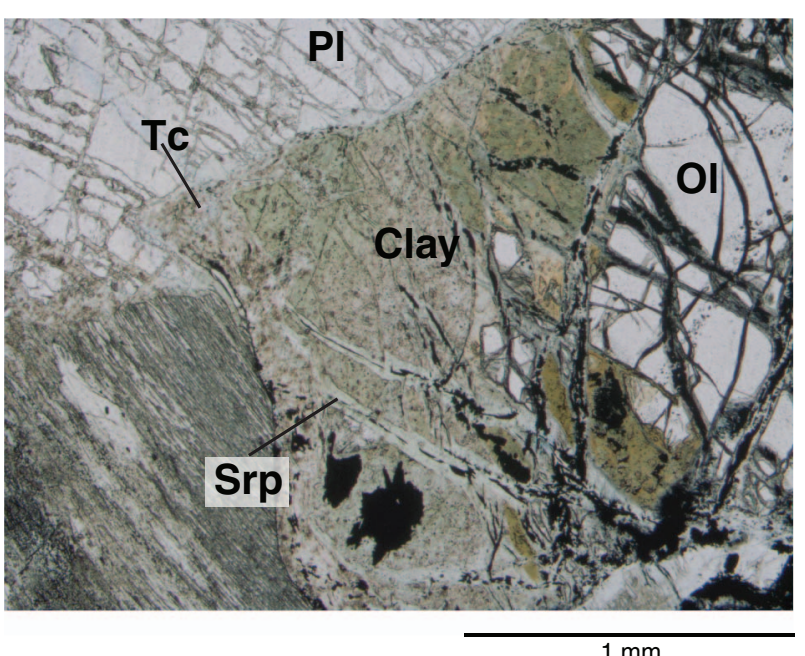

B

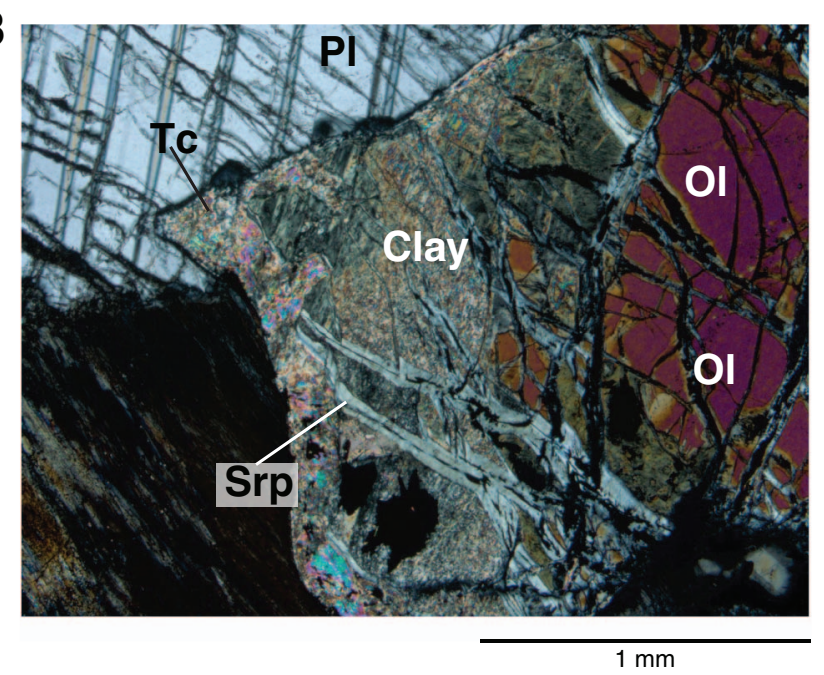


Figure F22. Serpentinized olivine (Ol) in troctolite (Thin Section 131; Sample 345-U1415P-16R-1, 100-102 cm). Plagioclase ( $\mathrm{Pl})$ adjacent to intensely serpentinized olivine is highly altered to prehnite ( $\mathrm{Pr})$. Srp $=$ serpentine. A. Plane-polarized light. B. Under crossed polars.
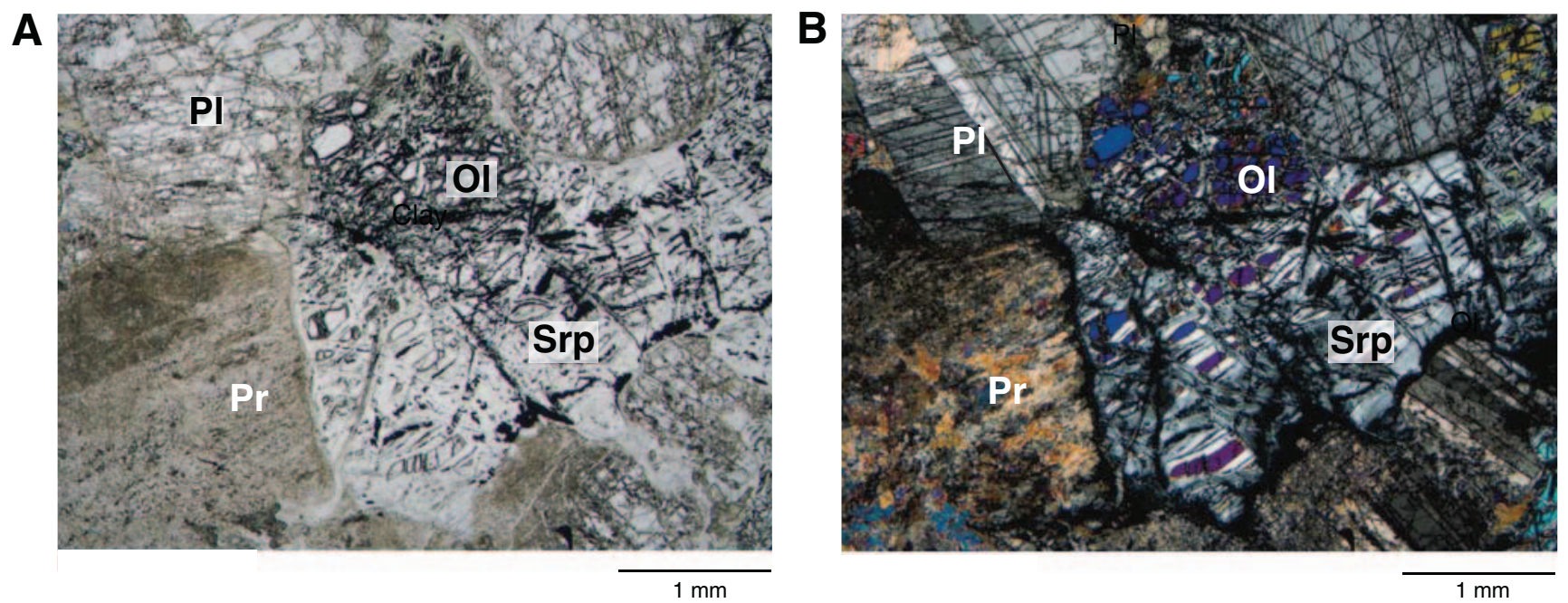
Figure F23. Amphibole (Am) replacing clinopyroxene (Cpx) along cleavage planes and microcracks in orthopyroxene-bearing olivine gabbro (Thin Section 98; Sample 345-U1415P-4G-1, 10-13 cm). Pl = plagioclase. A. Plane-polarized light. B. Under crossed polars.

A

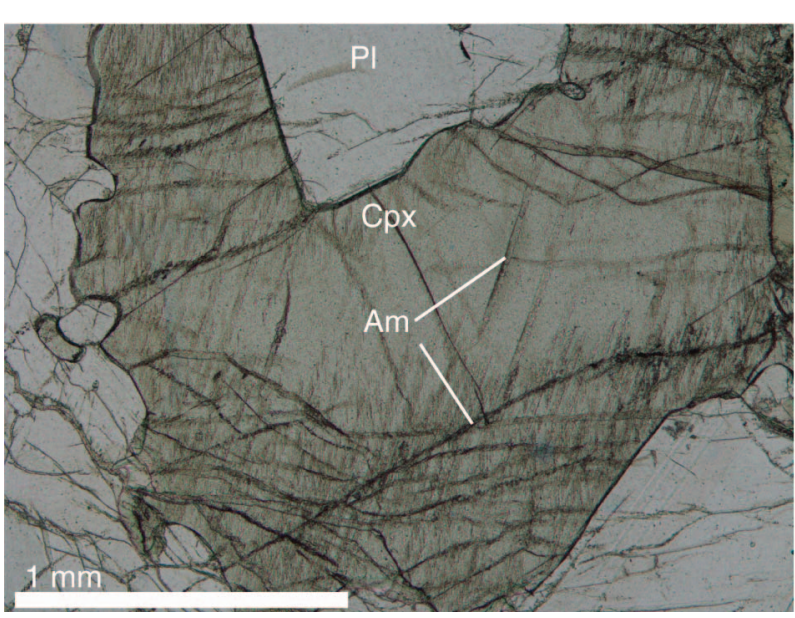

B

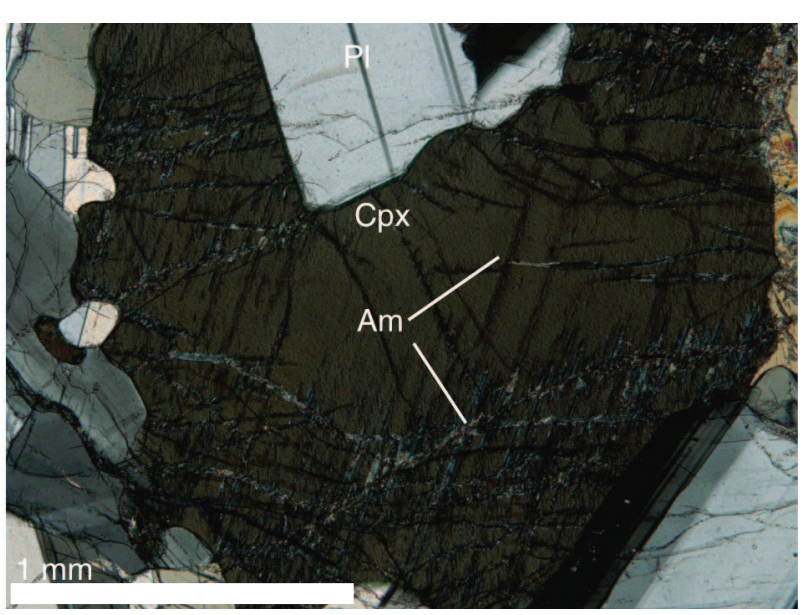


Figure F24. Secondary clinopyroxene (Cpx) surrounding a patch of colorless and pale green amphibole (Am) replacing primary clinopyroxene in olivine (Ol) gabbro (Thin Section 107; Sample 345-U1415P-6R-1, 101-103 $\mathrm{cm})$. Secondary pyroxene is rich in tiny oxide and/or sulfide inclusions. $\mathrm{Pl}=$ plagioclase. $\mathrm{A}$. Plane-polarized light. B. Under crossed polars.

A

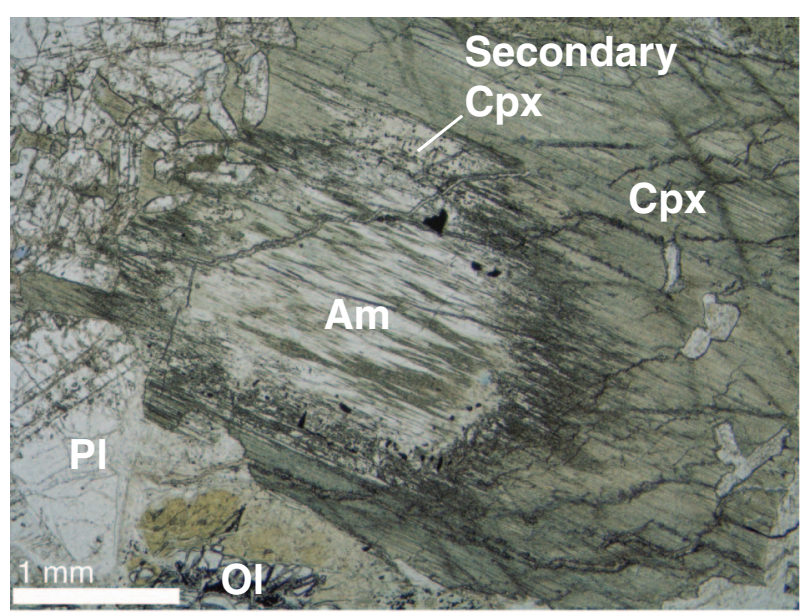

B

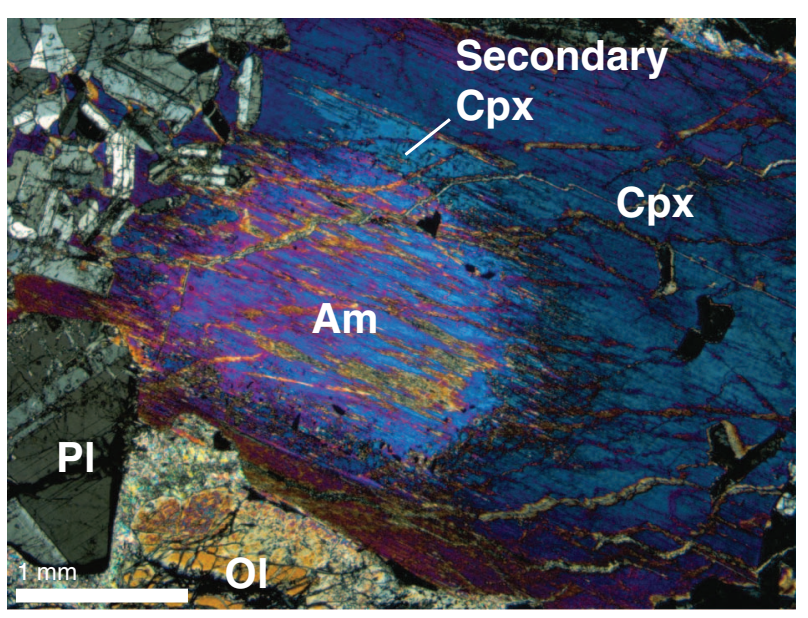


Figure F25. Alteration of clinopyroxene (Cpx) in intensely altered troctolite (Thin Section 136; Sample 345U1415P-20R-1, 67-68 cm). Clinopyroxene is serpentinized as well as olivine (Ol), showing a "bastite" texture. Serpentine (Serp) replacing clinopyroxene has pale brownish color, suggesting a difference in composition from colorless serpentine after olivine. Primary plagioclase $(\mathrm{Pl})$ is intensely altered to pseudomorphs composed of prehnite (Pr), chlorite (Chl), and a small amount of garnet $(\mathrm{Ga})$ (or hydrogarnet). A. Plane-polarized light. B. Under crossed polars.
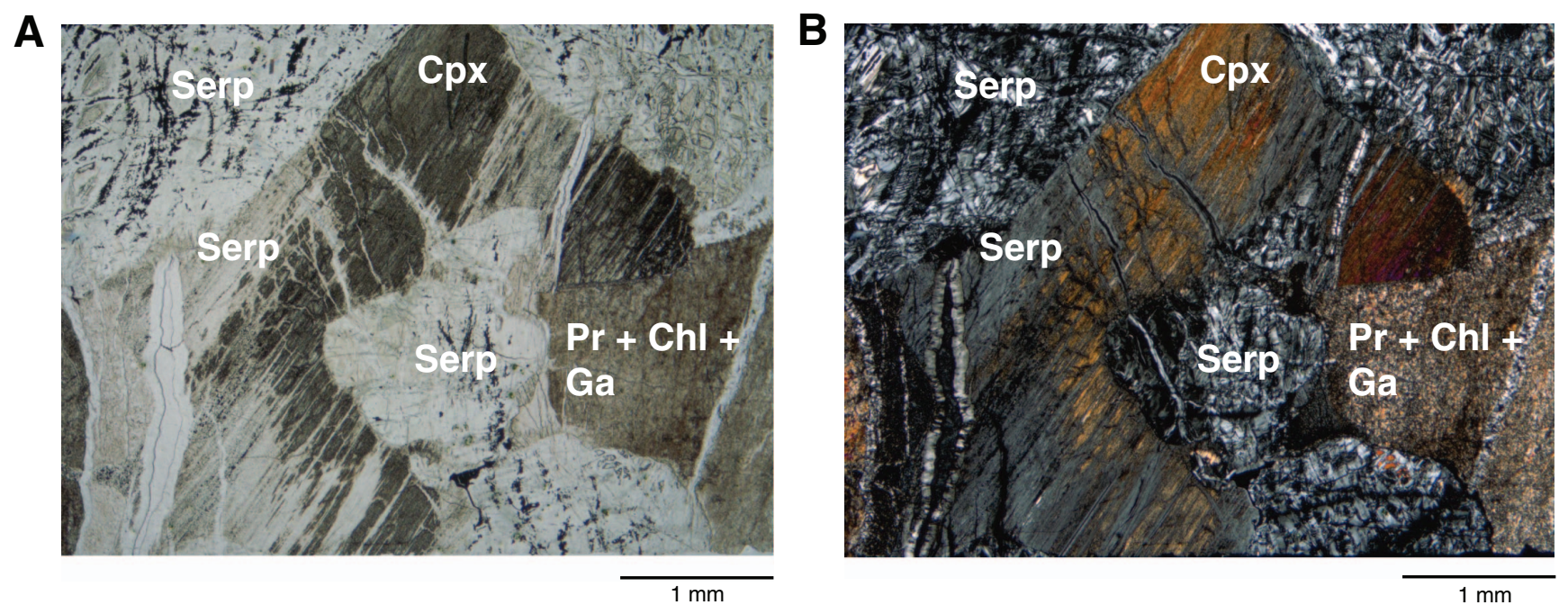
Figure F26. Orthopyroxene (Opx) in olivine gabbro, with a abundant clinopyroxene exsolution lamellae, replaced by pale green/brown amphibole (Am) and talc (Tc) at the rim and along microcracks (Thin Section 116; Sample 345-U1415P-8R-1, 80-83 cm). The amphibole has apparently low interference colors and may be mixed with chlorite $(\mathrm{Chl})$ or clay. $\mathrm{Pl}=$ plagioclase. $\mathrm{A}$. Plane-polarized light. B. Under crossed polars.
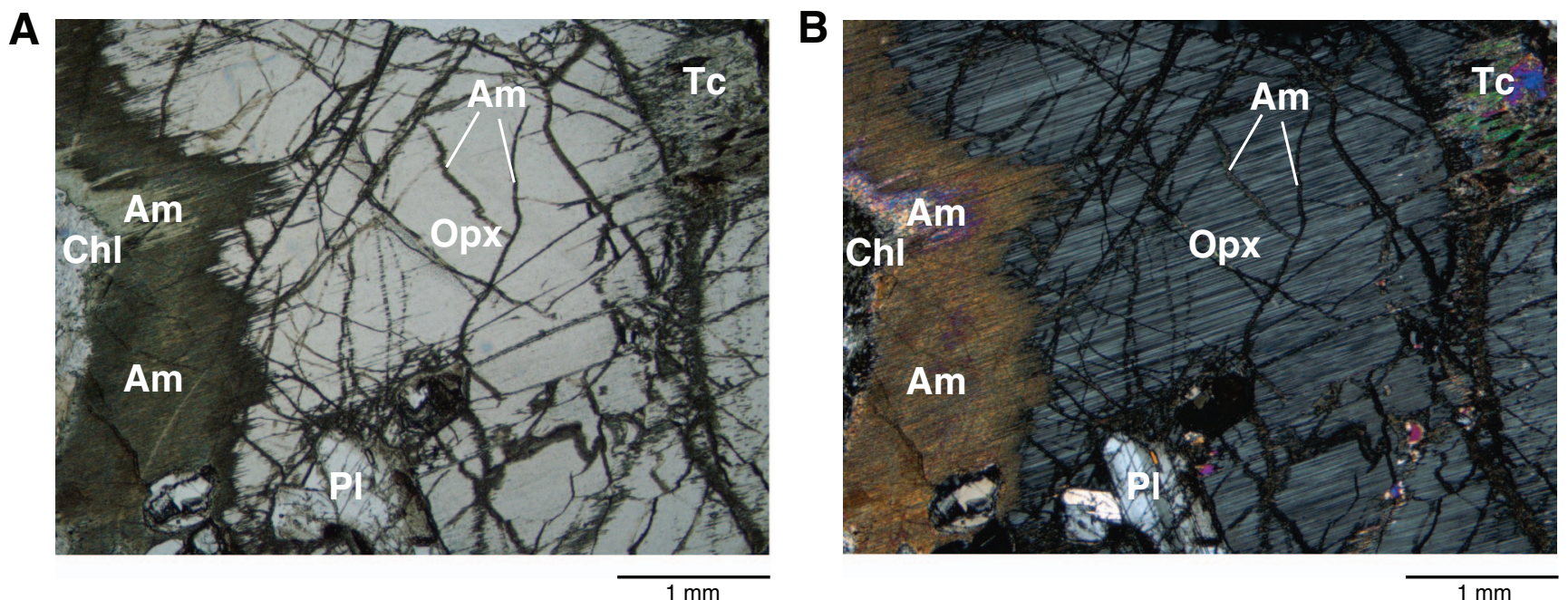
Figure F27. (A) Core recovery and lithologies and plagioclase alteration observed in (B) hand specimen and (C) thin section showing an increase in the percentage of plagioclase alteration and in the relative abundance of prehnite relative to chlorite with depth. Downhole changes generally correlate with the boundary between lithologic Units II and III, with higher alteration and prehnite abundance in the Troctolite Series. Ol= olivine, Opx = orthopyroxene.

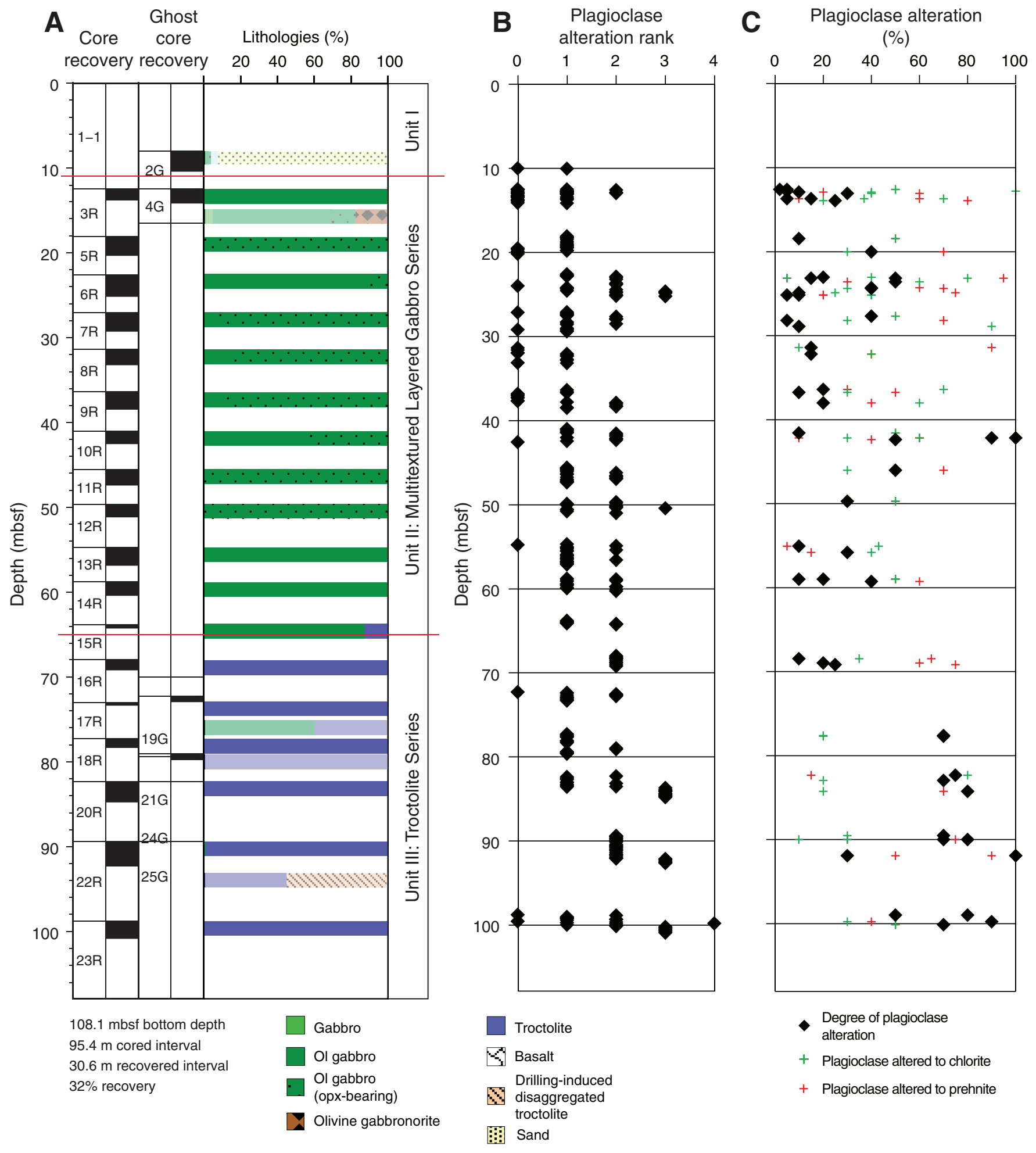


Figure F28. A, B. Gabbroic (Domain 1) and troctolitic (Domain 2) domains (Thin Section 140; Sample 345U1415P-22R-2, 113-115 cm [Piece 8]). Olivine gabbro has apparently intruded into the troctolite in this sample. Red rectangles in A mark the approximate location of the images in C-F. C, E. Alteration of plagioclase $(\mathrm{Pl})$ in Domain 1. Plagioclase ( $\mathrm{Pl})$ is slightly fractured and altered to fine-grained prehnite $(\mathrm{Pr})$ and chlorite $(\mathrm{Chl})$ along these microfractures. $\mathrm{Cpx}=$ clinopyroxene, $\mathrm{Serp}=$ serpentine, $\mathrm{Ca}=$ carbonate. $\mathrm{D}, \mathrm{F}$. Alteration of plagioclase in Domain 2. Plagioclase is completely replaced by both fine- and coarse-grained prehnite as well as lesser amounts of chlorite and possible hydrogarnet. A, C, and D are under plane-polarized light; B, E, and F are under crossed polars.
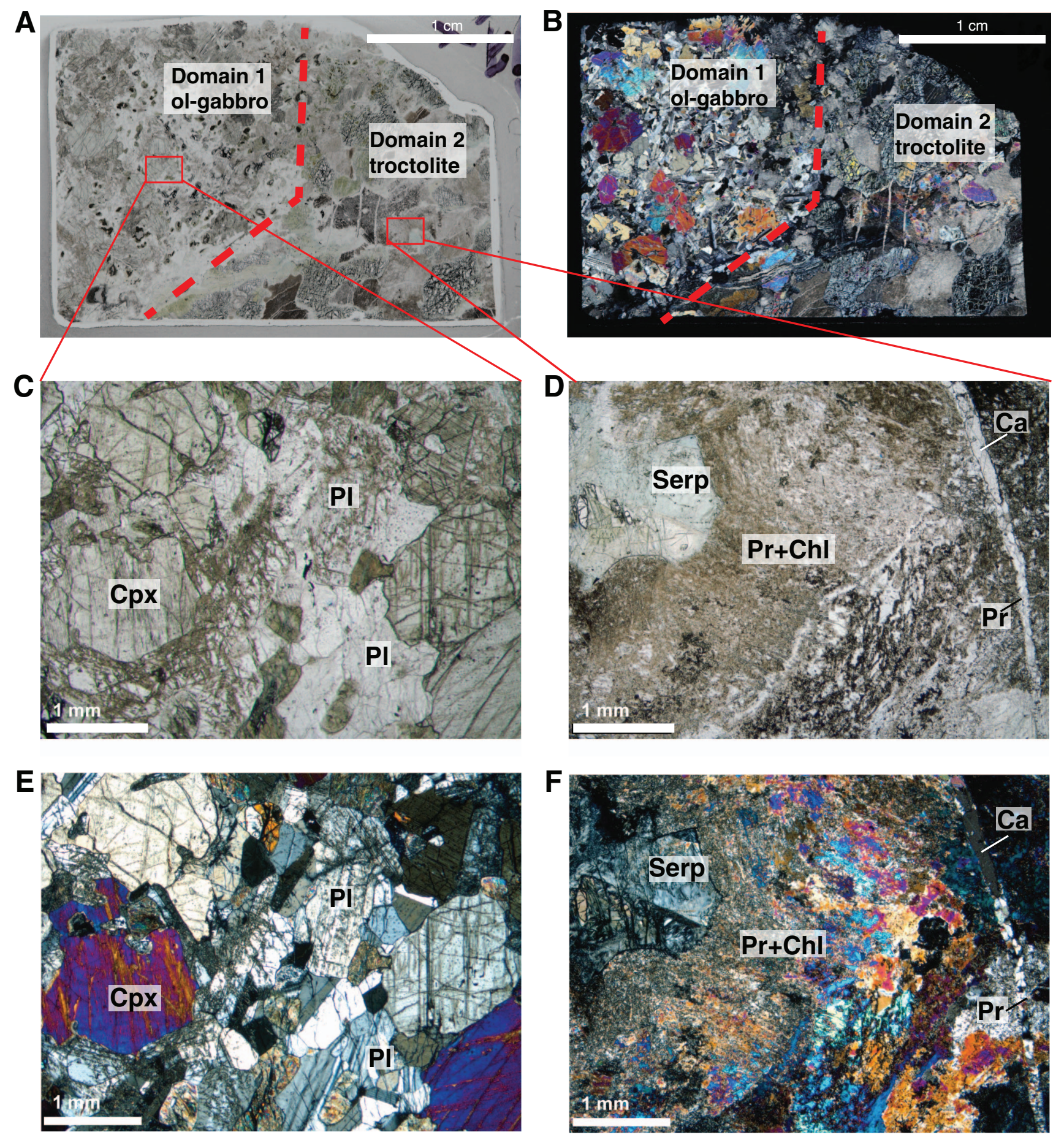
Figure F29. Characteristic sulfide assemblages (reflected light). A. Euhedral pyrite (Py) in serpentine after olivine (Thin Section 120; Sample 345-U1415P-10R-1, 60-62 cm). B. Chalcopyrite (Ccp) and pyrite intergrown within plagioclase (Thin Section 99; Sample 345-U1415P-4G-1, 41-43 cm). Silicate gangue appears dark gray. C. Heazlewoodite $(\mathrm{Hz})$ replacing pentlandite $(\mathrm{Pn})$ at the grain boundary and along cleavage plane and mantled by magnetite (Mt) in talc after olivine (Thin Section 112; Sample 345-U1415P-7R-1, 60-62 cm). Silicate gangue appears dark gray. D. Magnetite surrounding pyrohotite (Po)-pentlandite intergrowth in serpentine after olivine (Thin Section 128; Sample 345-U1415P-14R-1, 50-52 cm). Pentlandite is altered to pyrite(?) or chalcopyrite along the grain boundary and where the pentlandite was sheared, forming sigmoidal replacements. Magnetite appears ragged on grain boundaries suggesting dissolution. Magnetite stringers are deformed and appear sheared. Serpentine gangue appears dark gray.
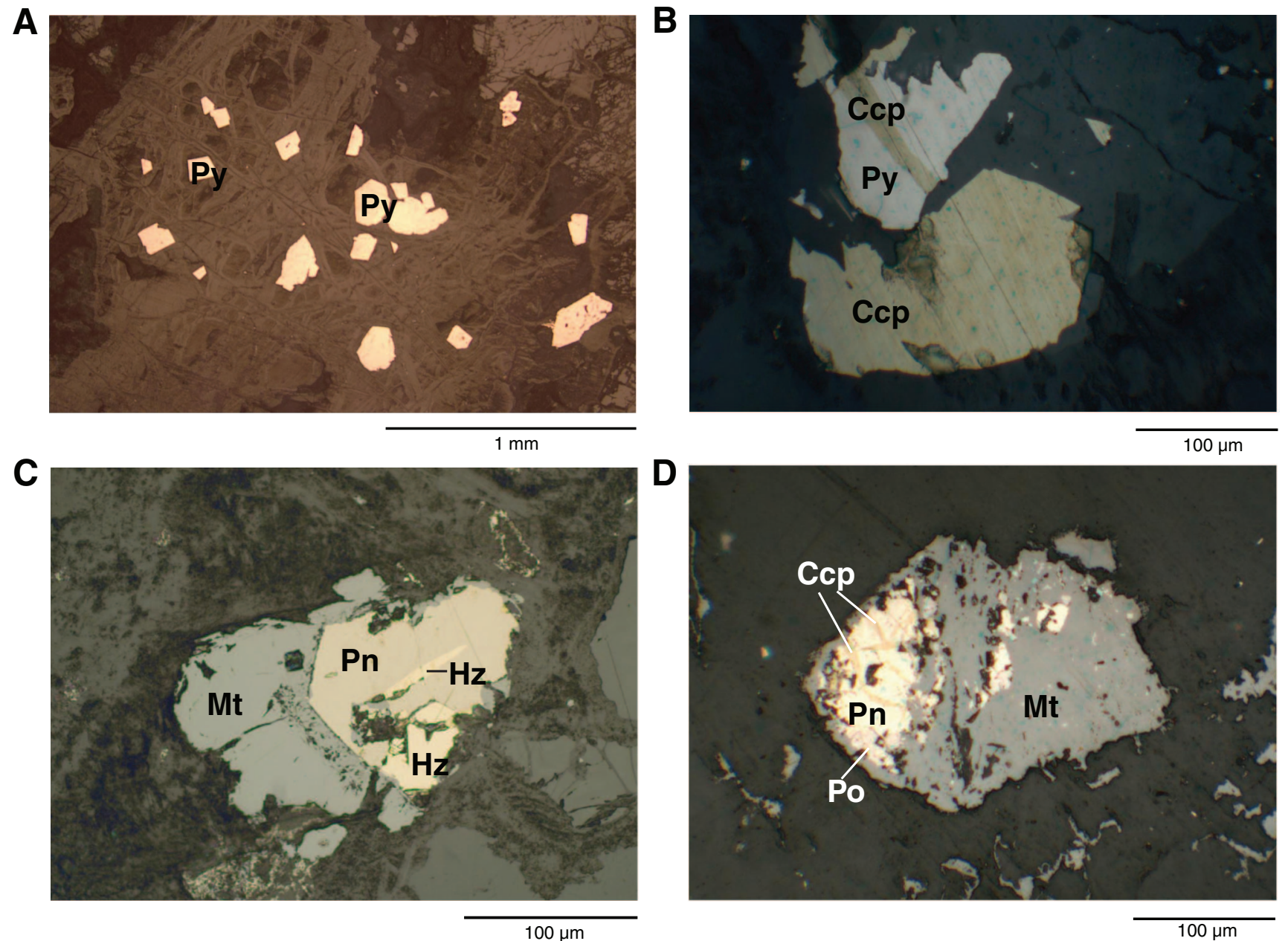
Figure F30. Core recovery and variations in vein type downhole, Hole U1415P. Ol = olivine, Opx = orthopyroxene.

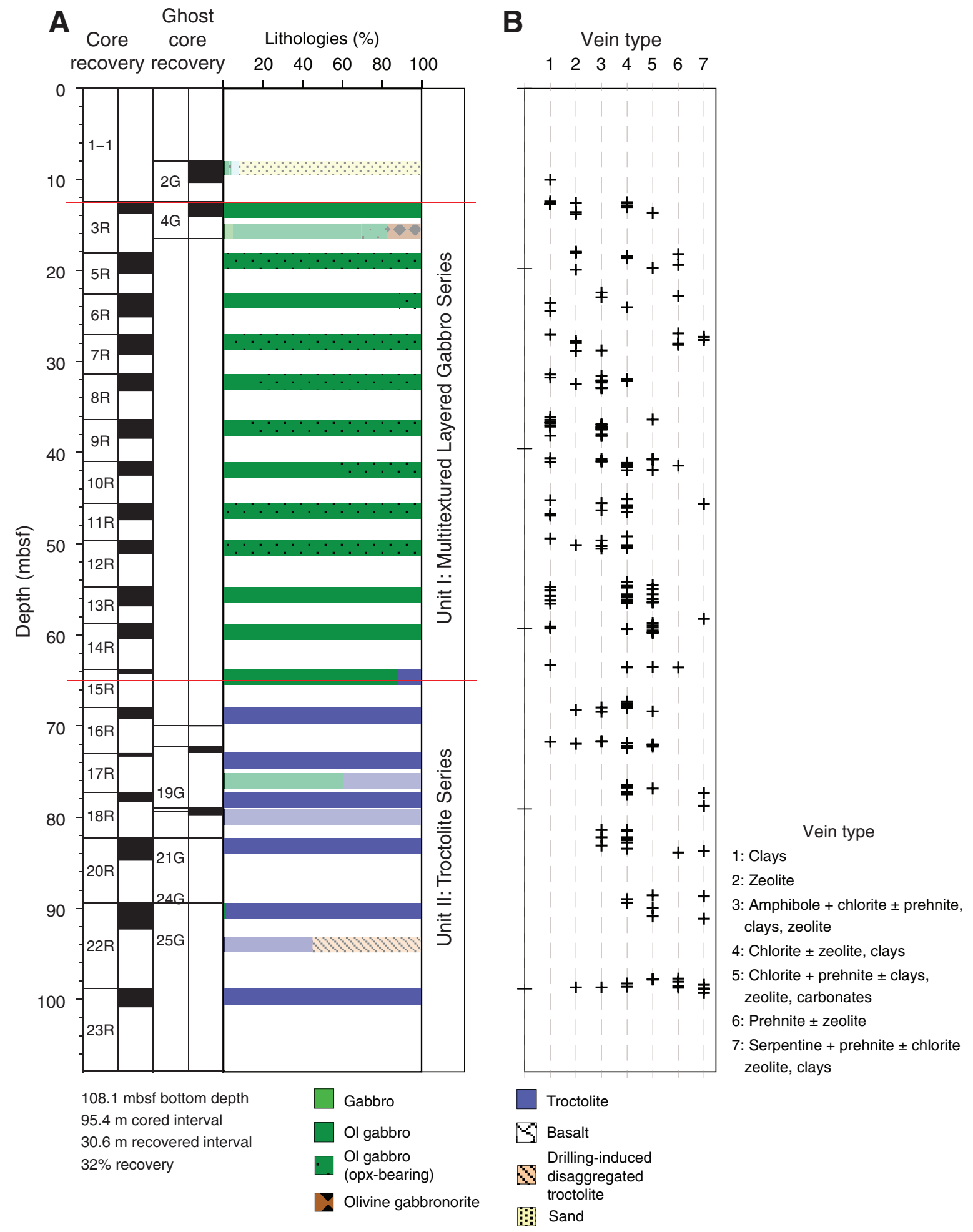


Figure F31. Relative abundance of different vein types in the Unit I surficial rubble, Unit II Multitextured Layered Gabbro Series, and Unit III Troctolite Series, Hole U1415P.
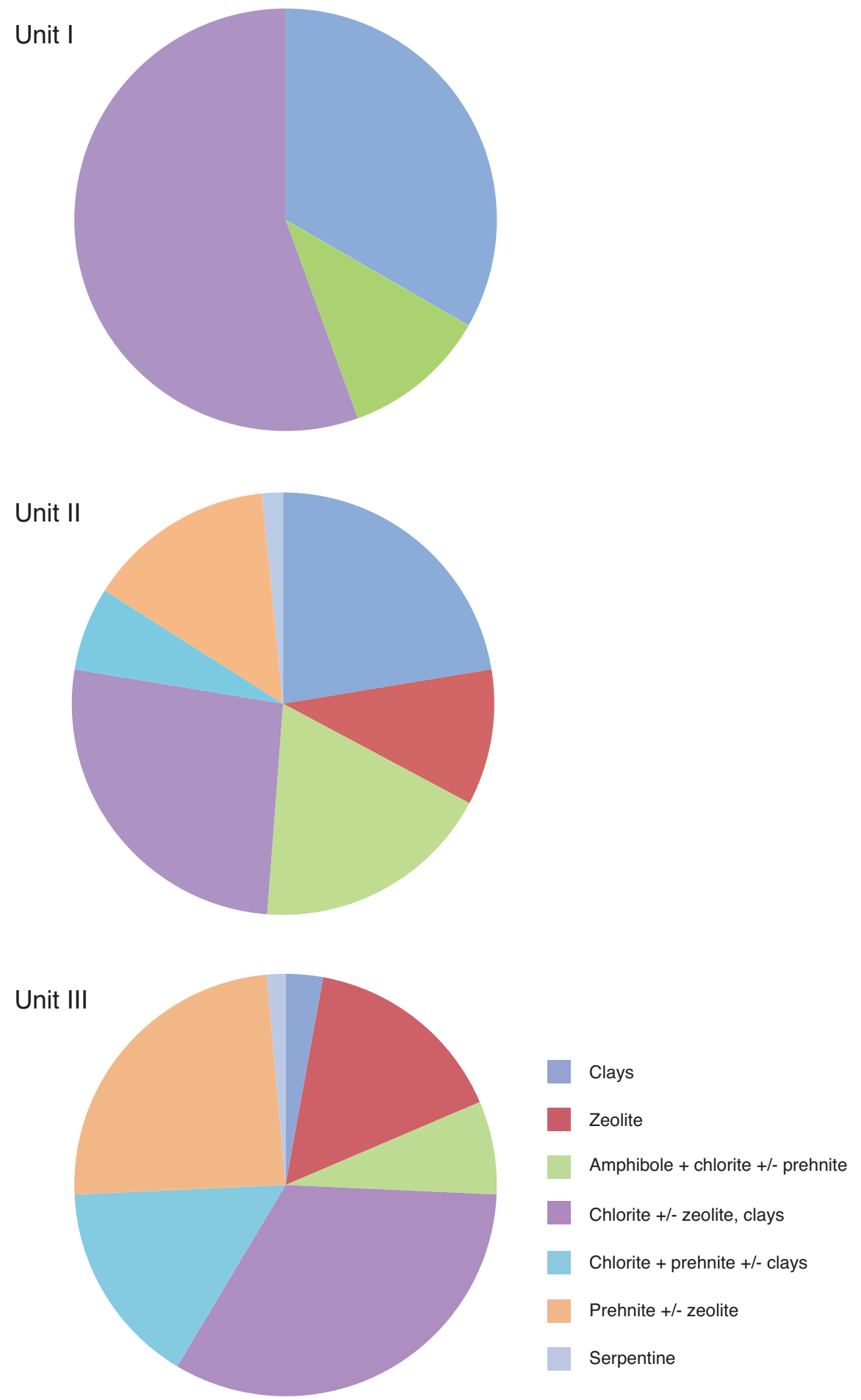
Figure F32. Typical vein morphology and mineralogy in olivine gabbro from Units II III (under crossed polars unless otherwise indicated). A. Chlorite (Chl) and zeolite (Zeo) vein in olivine (Ol) gabbro cutting a clinopyroxene (Cpx) oikocryst with no vein halo (Thin Section 125; Sample 345-U1415P-13R-1, 39-42 cm [Piece 5]). B. Amphibole veins crosscut by a prehnite (Pr) vein in a cataclastic sample (Thin Section 121; Sample 345U1415P-10R-1, 121-134 cm [Piece 13]). C. Large serpentine (Se) and chlorite vein with carbonate (Car) and prehnite patches and a chloritized vein halo in a troctolitic sample from Unit III (Thin Section 129; Sample 345-U1415P-16R-1, 47-49 cm [Piece 6]). D. Close-up core image of troctolite cut by a prehnite vein showing the microrodingite reaction in which olivine is altered to serpentine and plagioclase is altered to prehnite (Sample 345-U1415P-20R-2, 0-8 cm [Piece 1]). E. Large fibrous serpentine ladder vein crosscut by gashes filled with chlorite and clay $(\mathrm{Cl})$ minerals (Sample 345-U1415P-20R-1, 3-6 cm [Piece 1]; plane-polarized light). F. Serpentine vein in E showing crosscutting clay mineral veins. Abundant magnetite occurs in the vein selvage.

A

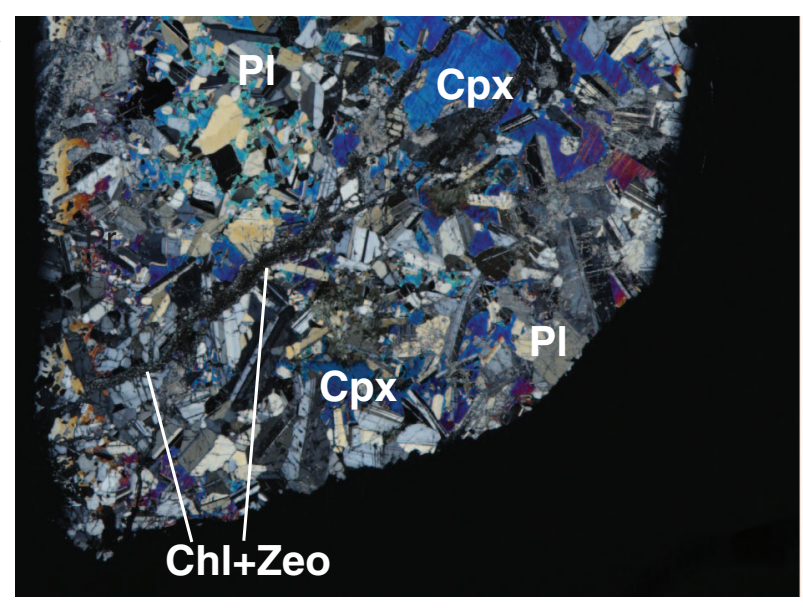

C
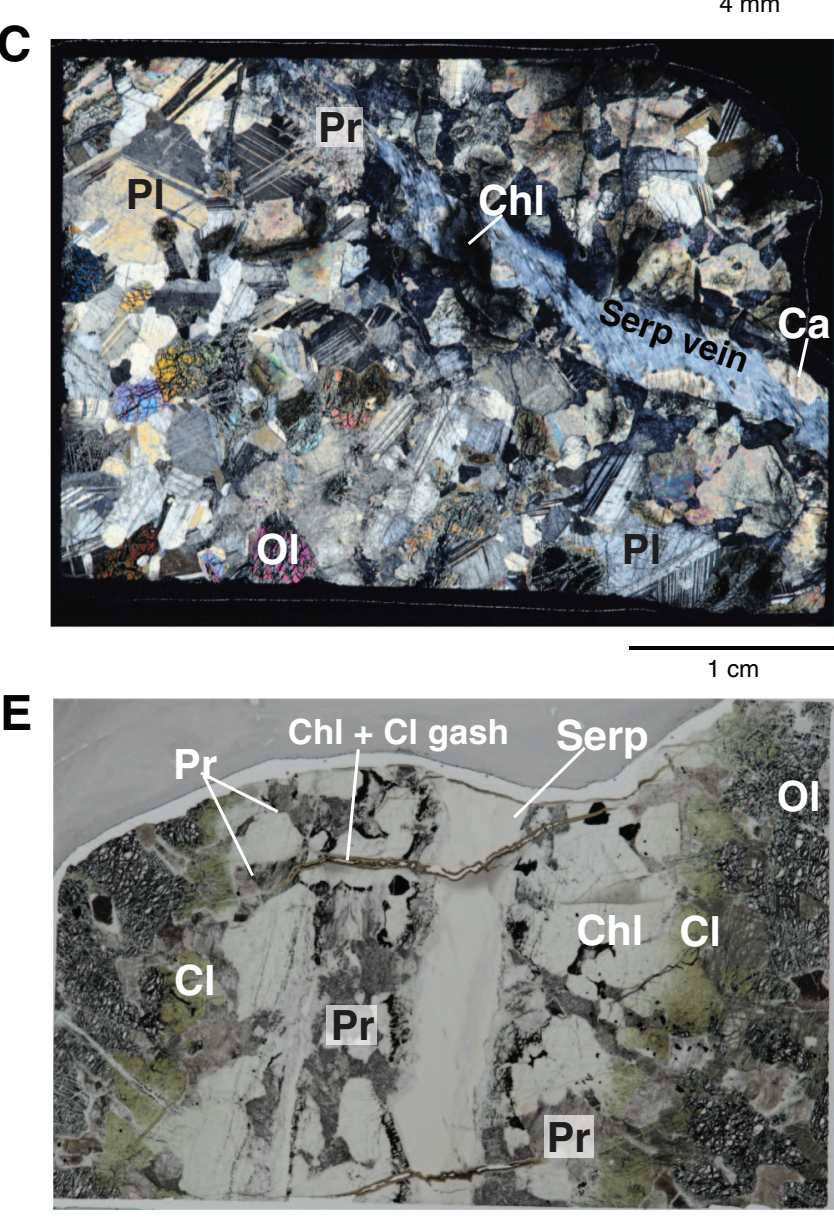

B

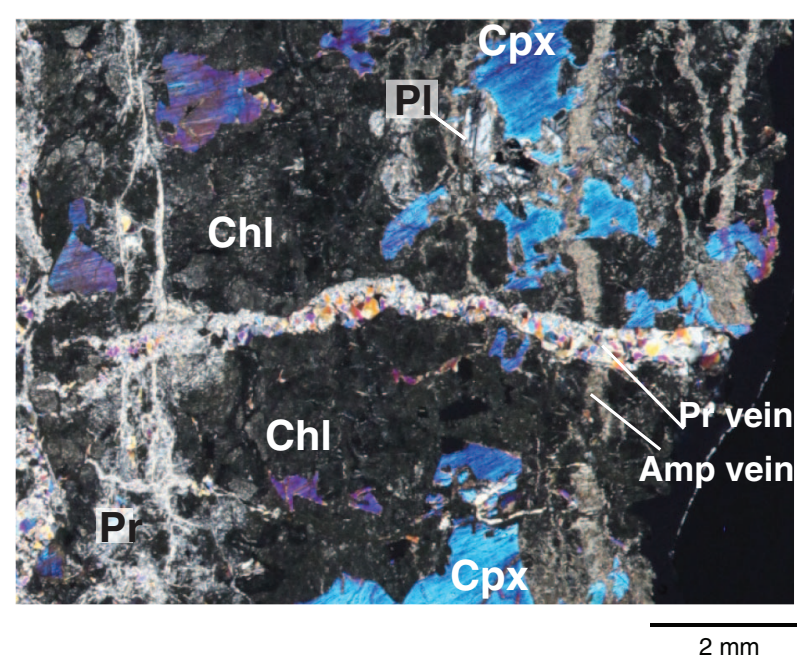

D
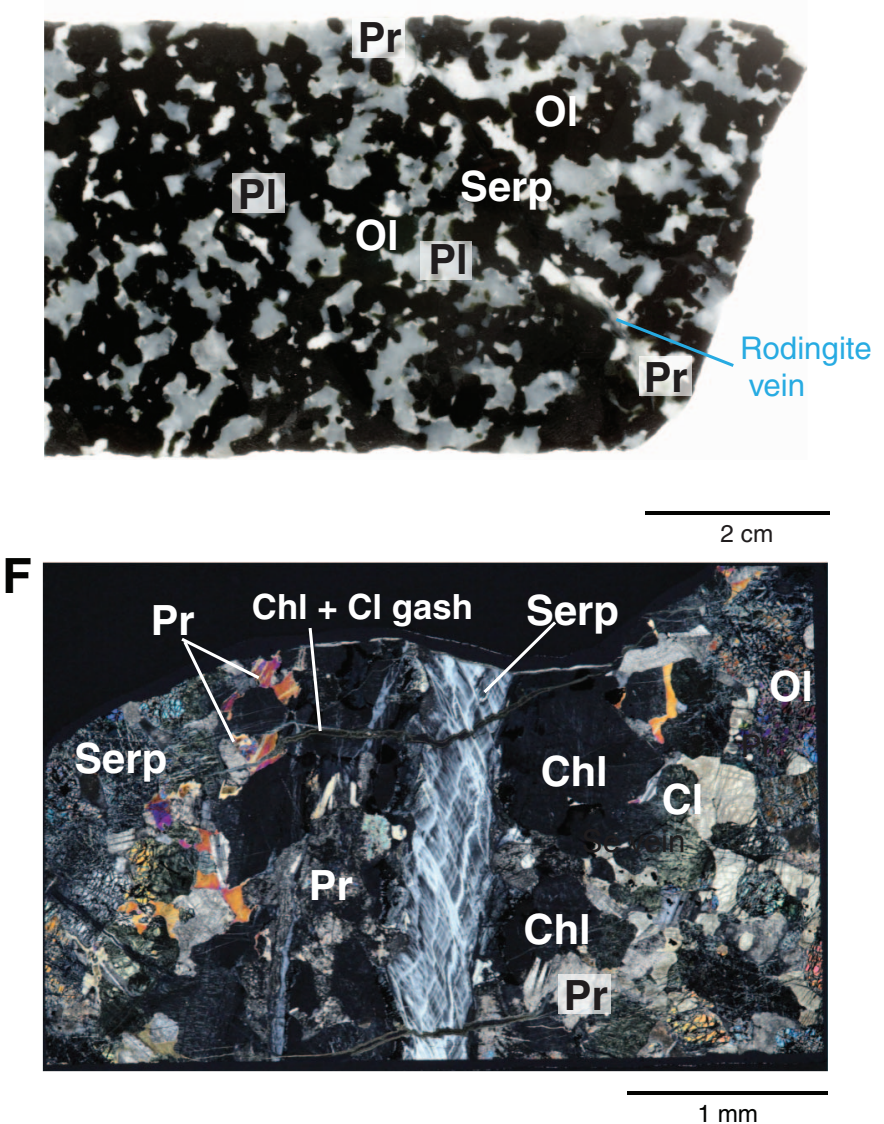
Figure F33. Primary vein features. $\mathrm{Pl}=$ plagioclase, $\mathrm{Cpx}=$ clinopyroxene. $\mathrm{A}$. Chlorite $(\mathrm{Chl})$ vein showing radiating texture and partial replacement by prehnite (Pr) in gabbro (Thin Section 125; Sample 345-U1415P-13R1, 39-42 cm [Piece 5]). B. Massive chlorite vein crosscut by a thin prehnite vein in gabbro (Thin Section 109; Sample 345-U1415P-6R-2, 38-41 cm [Piece 4]). C. Cross-fiber chlorite vein with partial replacement by prehnite and central injection of zeolite (Zeo) in gabbro (Thin Section 108; Sample 345-U1415P-6R-2, 31-34 cm [Piece 3]). D. Prehnite vein in a cataclastic sample (Thin Section 121; Sample 345-U1415P-10R-1, 121-134 cm [Piece 13]). E. Amphibole (Amp) vein crosscut by a thin chlorite vein in gabbro (Thin Section 106; Sample 345U1415P-6R-1, 58-61 cm [Piece 6]). F. Chlorite vein showing partial replacement by prehnite and coarse-grained carbonate (Ca) in gabbro (Thin Section 97; Sample 345-U1415P-3R-1, 120-123 cm [Piece 20A]).

A

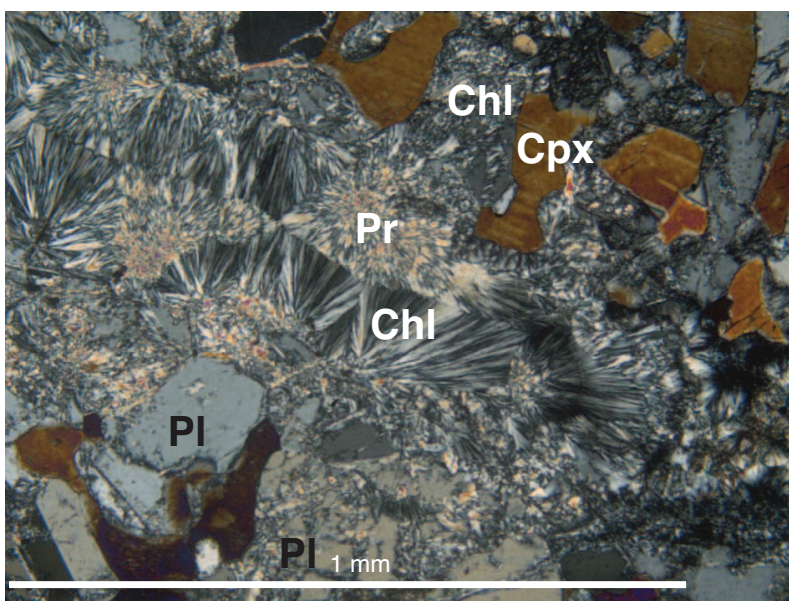

C

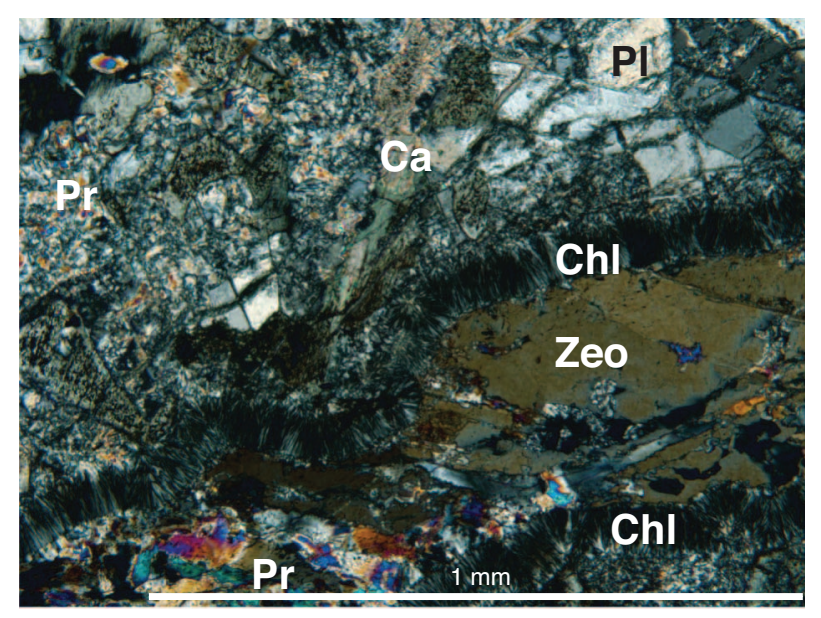

E

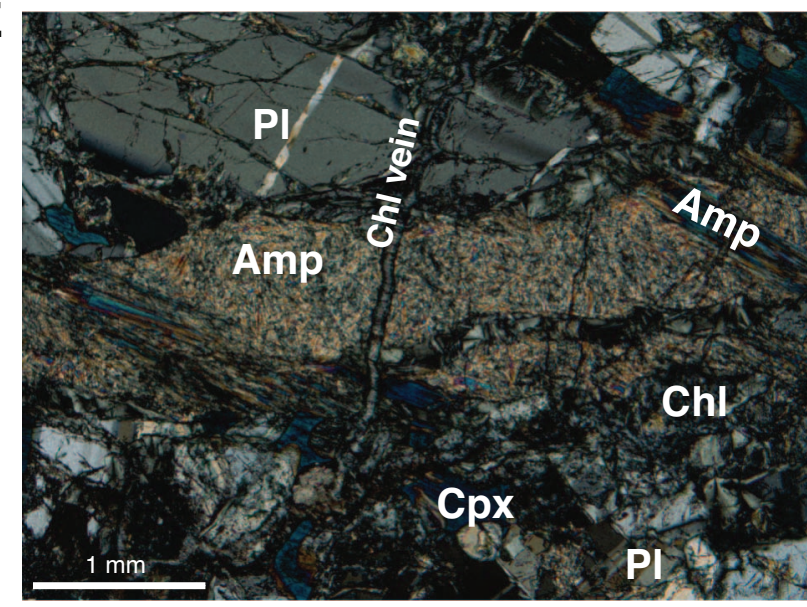

B

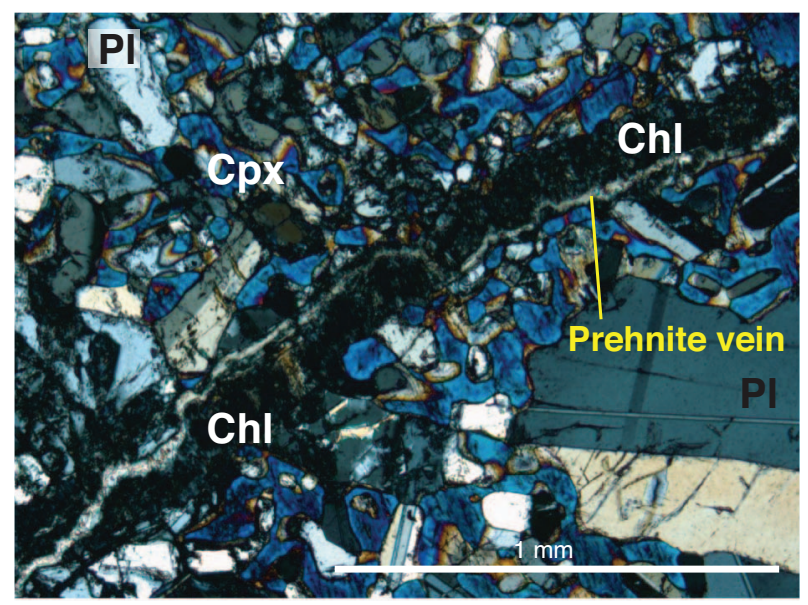

D

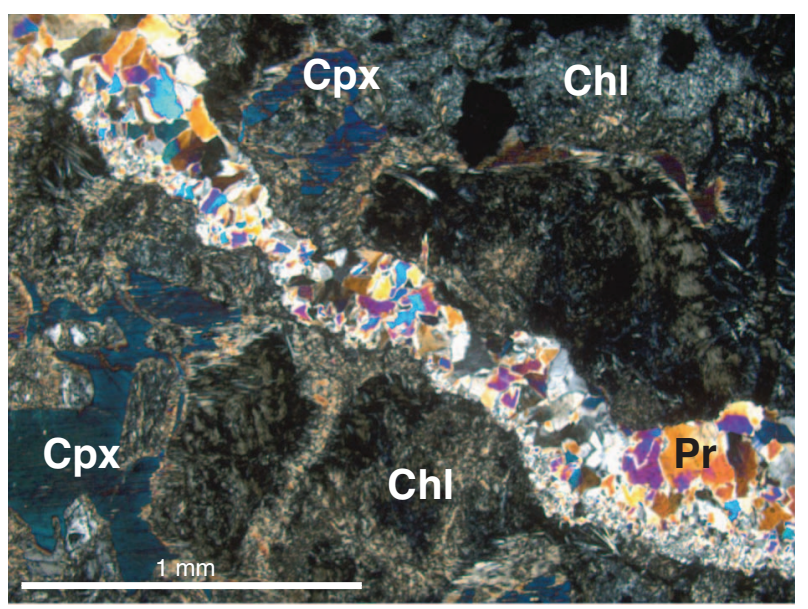

F

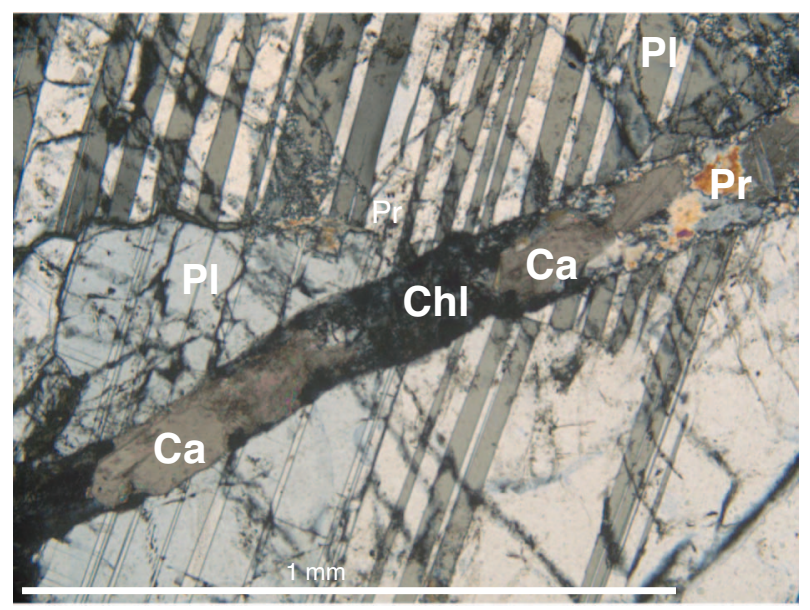


Figure F34. Secondary clinopyroxene vein in troctolite (Sample 345-U1415P-23R-1, 100-104 cm [Piece 14]). Red box indicates the region sampled for X-ray diffraction analysis.

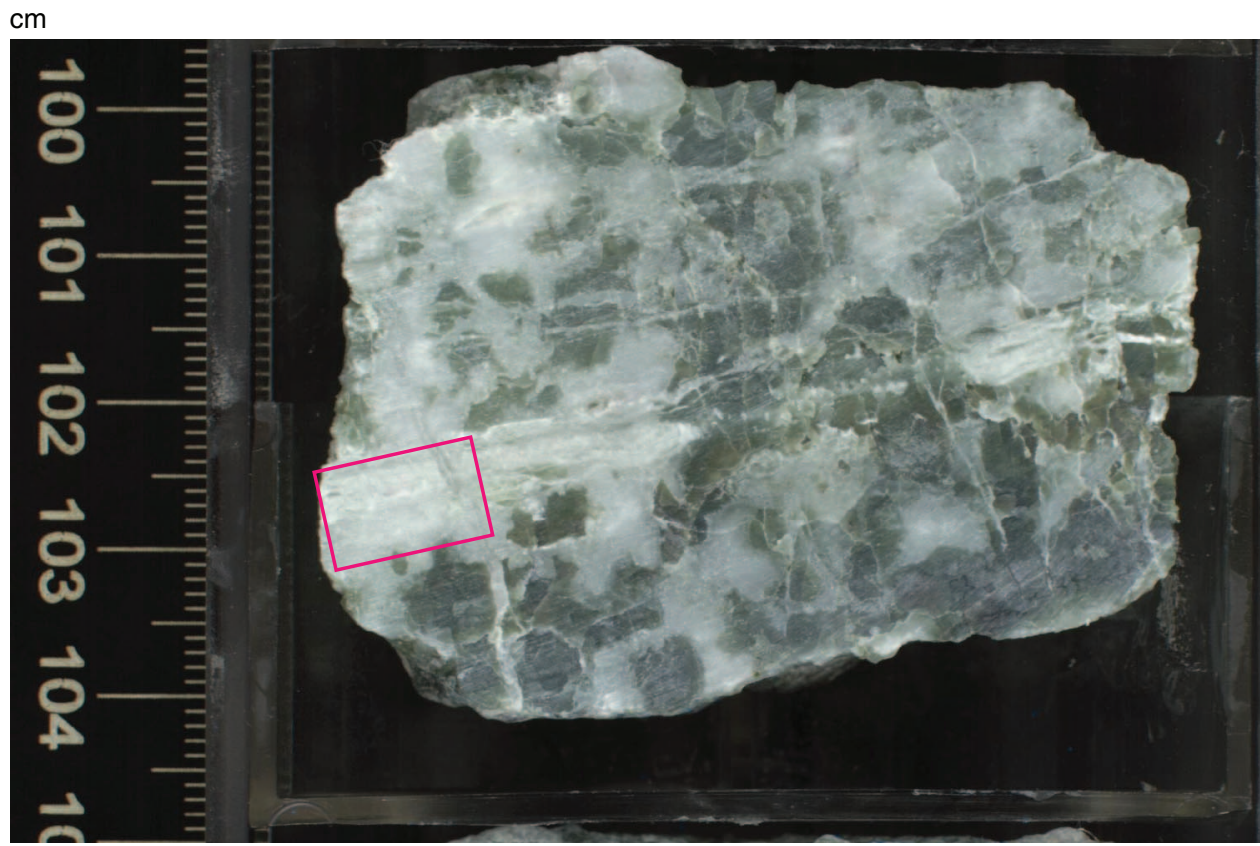


Figure F35. Chlorite-prehnite overprinting in a chlorite vein halo in Unit III troctolite (Sample 345-U1415P19G-1, 50-58 cm, [Piece 8]. Typical background alteration includes serpentinization of olivine and alteration of plagioclase to prehnite. In the vein halo, plagioclase is completely pseudomorphically replaced by prehnite, and olivine is intensely altered to chlorite and clay minerals.

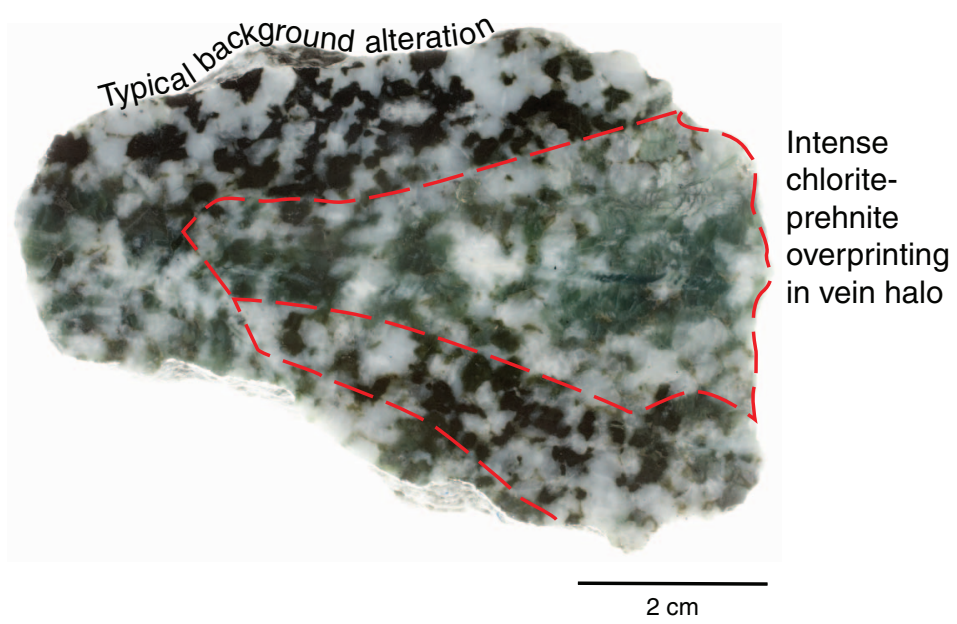


Figure F36. Rare cataclastic zone in the upper pale part of the image cutting gabbroic rock in Unit II (Thin Section 121; Sample 345-U1415P-10R-1, 131-134 cm [Piece 13]; cross-polarized light). The bright band of prehnite-cemented (PrC) cataclasite contains fragments (red) of clinopyroxene (Cpx), altered olivine, and prehnite $(\mathrm{Pr})$. Younger prehnite veins $(\mathrm{PrV})$ crosscut the cataclastic zone. $(\mathrm{Ol})=$ altered olivine, $\mathrm{V}=$ amphiboleclay minerals vein.

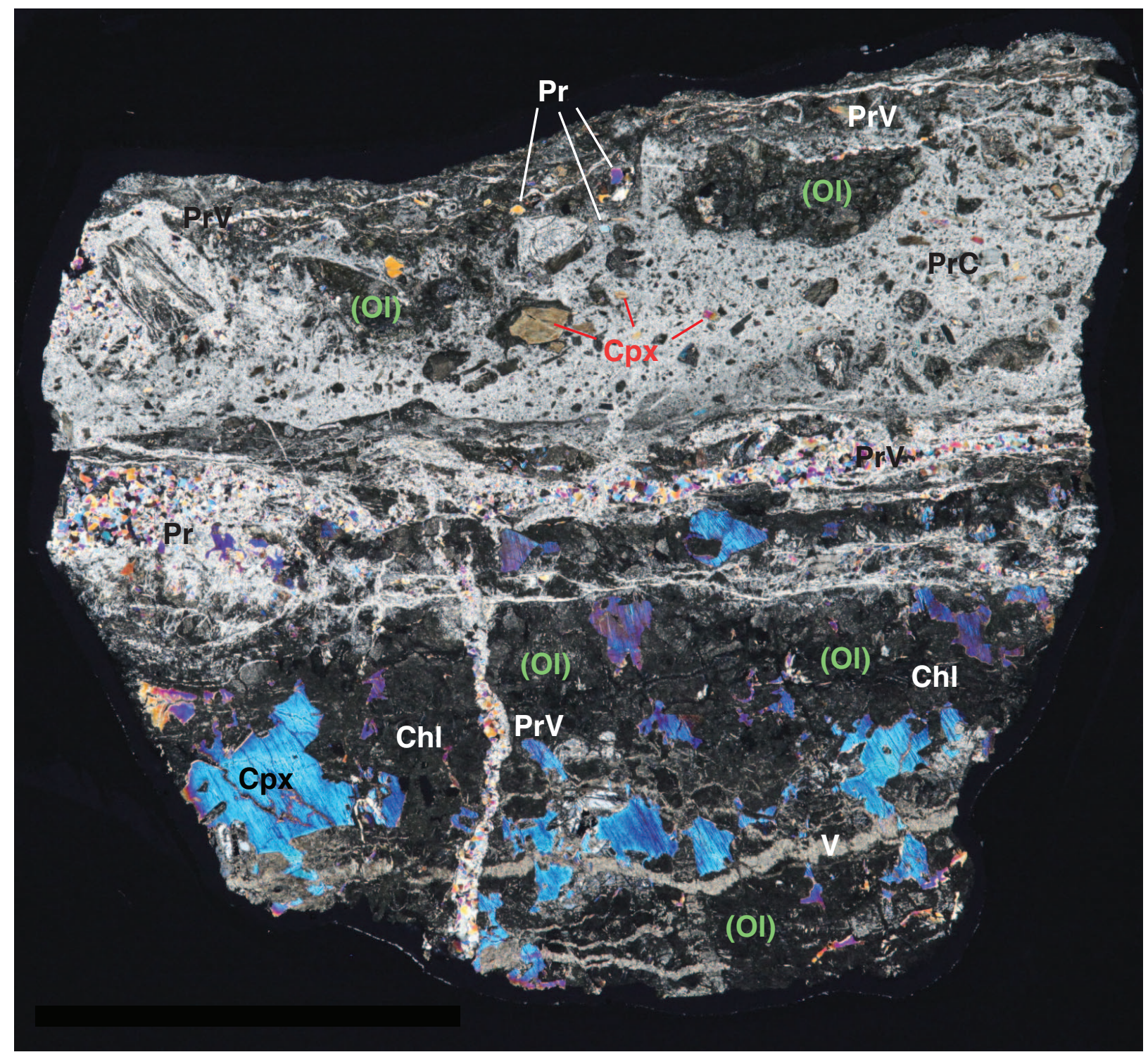

$1 \mathrm{~cm}$ 
Figure F37. Core recovery and magmatic layering and foliation dip, Holes U1415IJ and U1415P. Also shown is the location of layering in Hole U1415J, unit boundaries, and recovered contacts ( $n=$ number of measurements made).
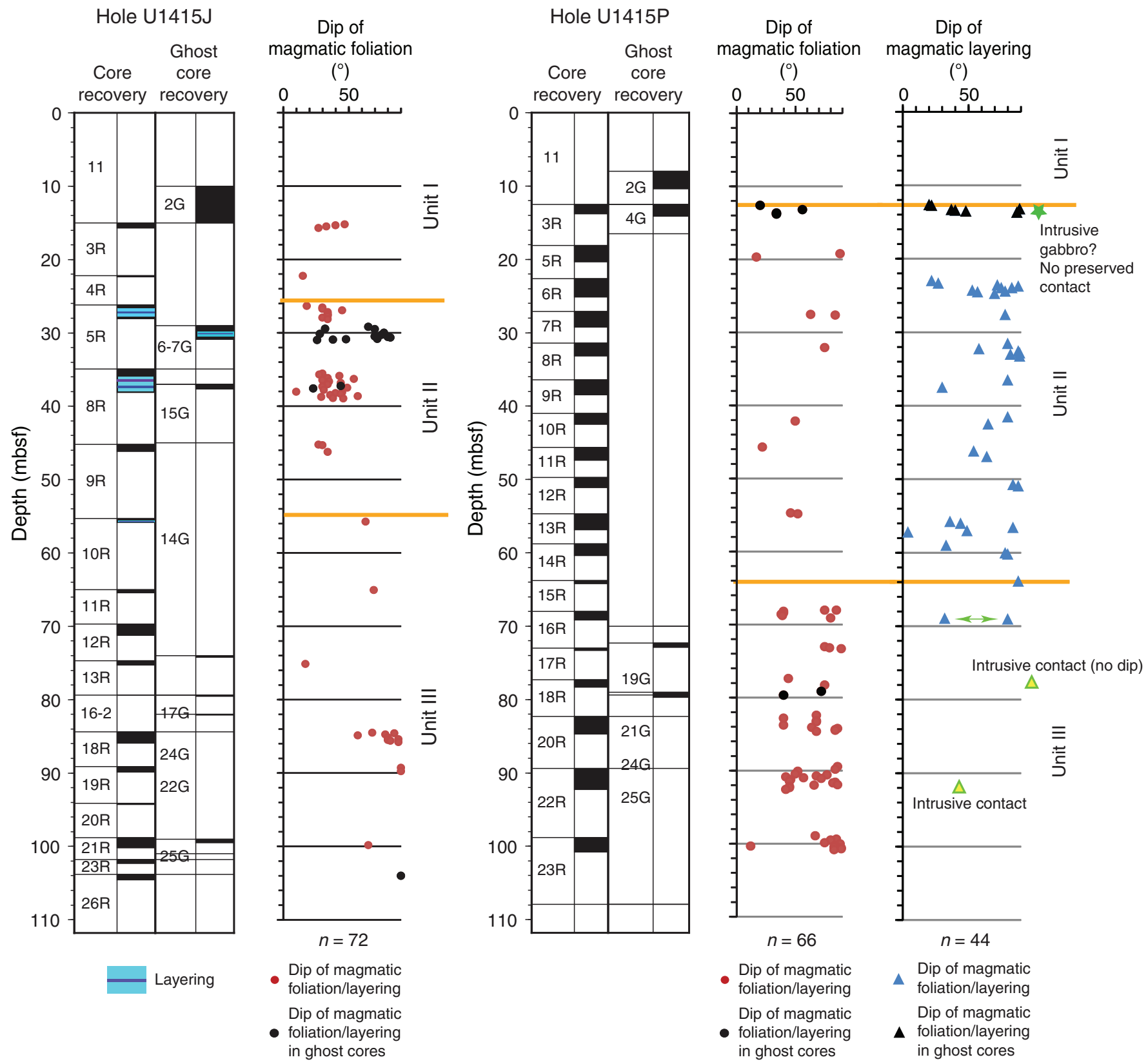

Dip of magmatic

foliation/layering

Dip of magmatic

- foliation/layering

in ghost cores

Dip of magmatic foliation/layering Dip of magmatic

- foliation/layering in ghost cores 
Figure F38. Examples of textural variations in steeply dipping leucocratic banding/layering in Unit II (dry images). A. Weak banding (interval 345U1415P-4G-1, 69-92 cm). B. Moderate banding (interval 345-U1415P-6R-1, 95-118 cm). Red box (tick mark shows upward direction) outlines region of image in Figure F42A. C. Moderate banding (interval 345-U1415P-6R-2, 30-53 cm). D. Distinct banding (interval 345-U1415P-8R-2, 3$26 \mathrm{~cm}$ ). E. Weak banding (interval 345-U1415P-14R-1, 115-129 cm).

A $\mathrm{cm}$

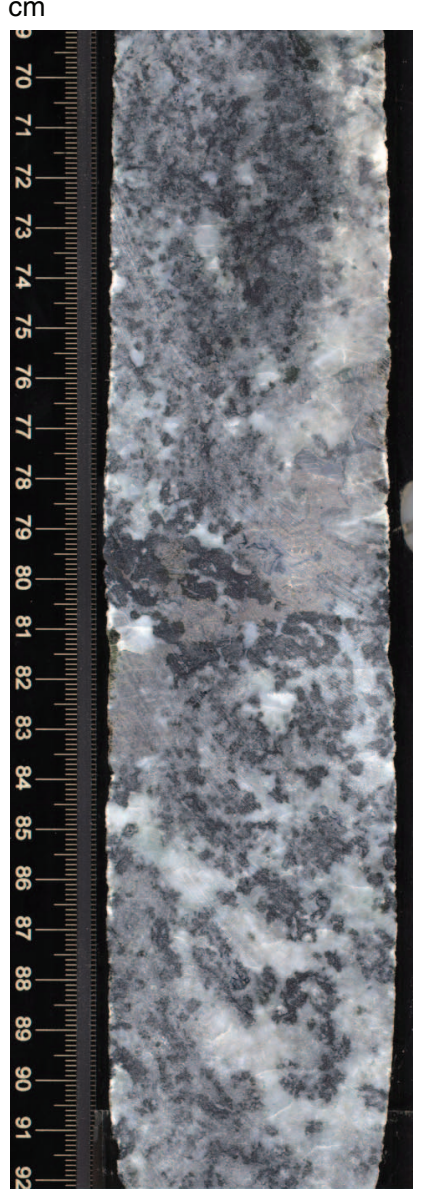

B $\mathrm{cm}$

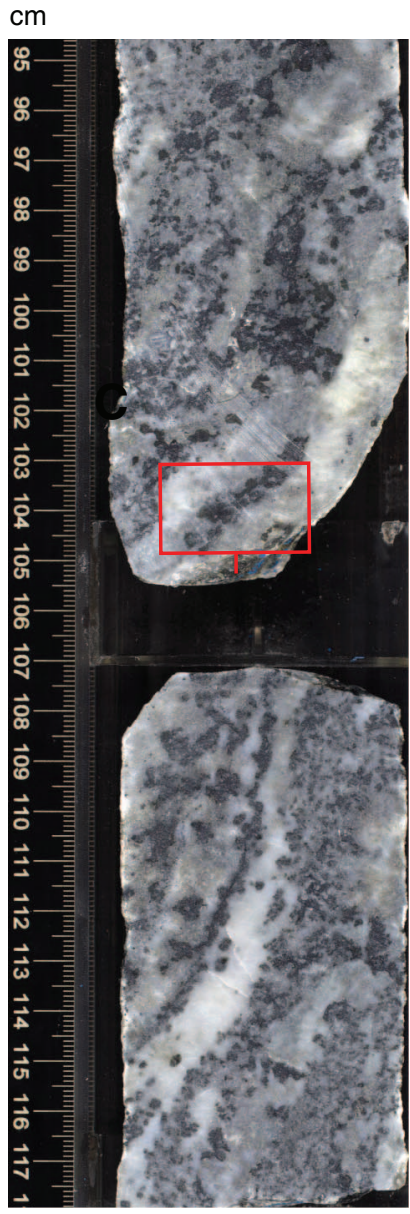

C $\mathrm{cm}$

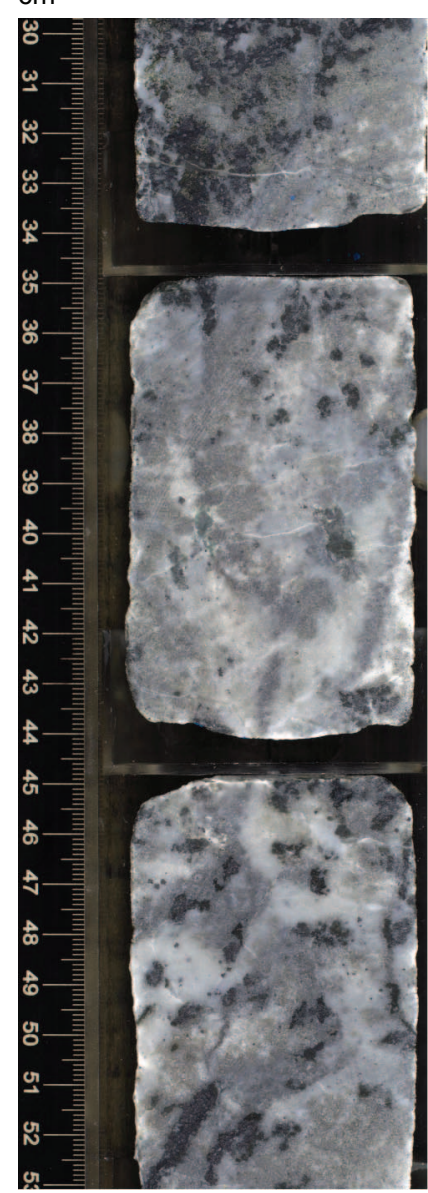

D ${ }_{\omega}^{\mathrm{cm}}$

E

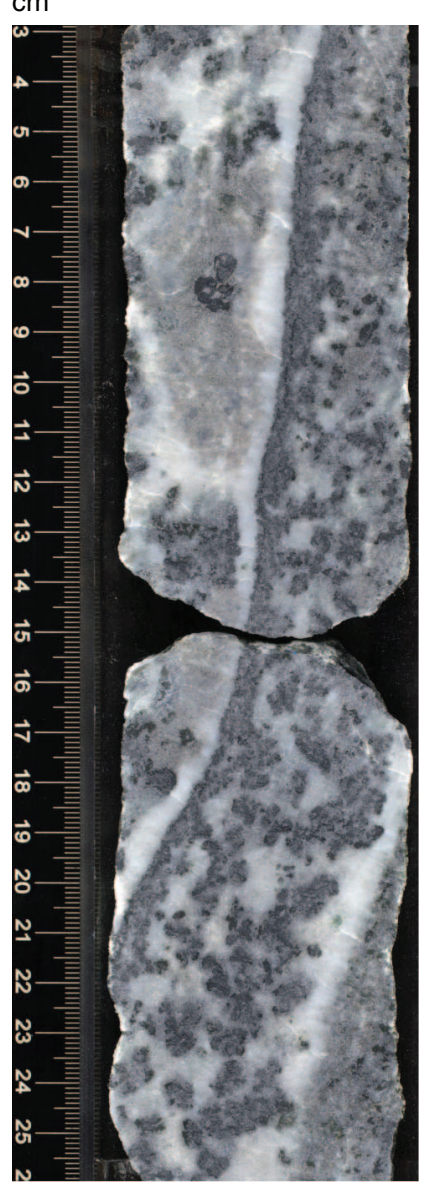

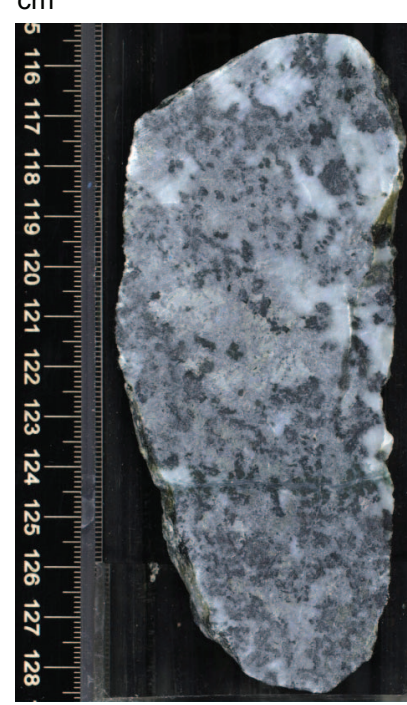


Figure F39. A-C. Layer of orthopyroxene-bearing olivine gabbro within an anorthositic gabbro (Sample 345U1415P-14R-1, 16-25 cm [Piece 3]). (A) Dry image; red box (tick mark shows upward direction) indicates location of image in B. (B) Lower contact (dashed red line) between orthopyroxene-bearing olivine gabbro and anorthositic gabbro. Red box indicates location of image in C. (C) Relatively large cluster of intergrown and deformed plagioclase crystals in olivine gabbro. D. Complex plagioclase crystal texture that shows subgrain development that may have captured partial annealing (Sample 345-U1415P-11R-1, 43-44 cm [Piece 6]). B, C, and $\mathrm{D}$ are under crossed polars.

A

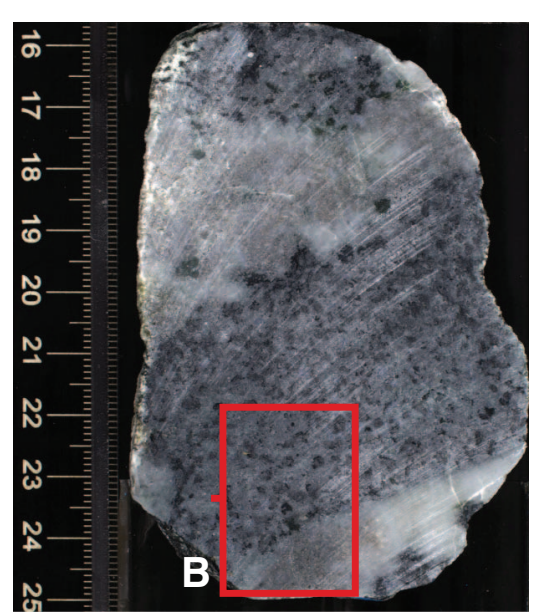

B

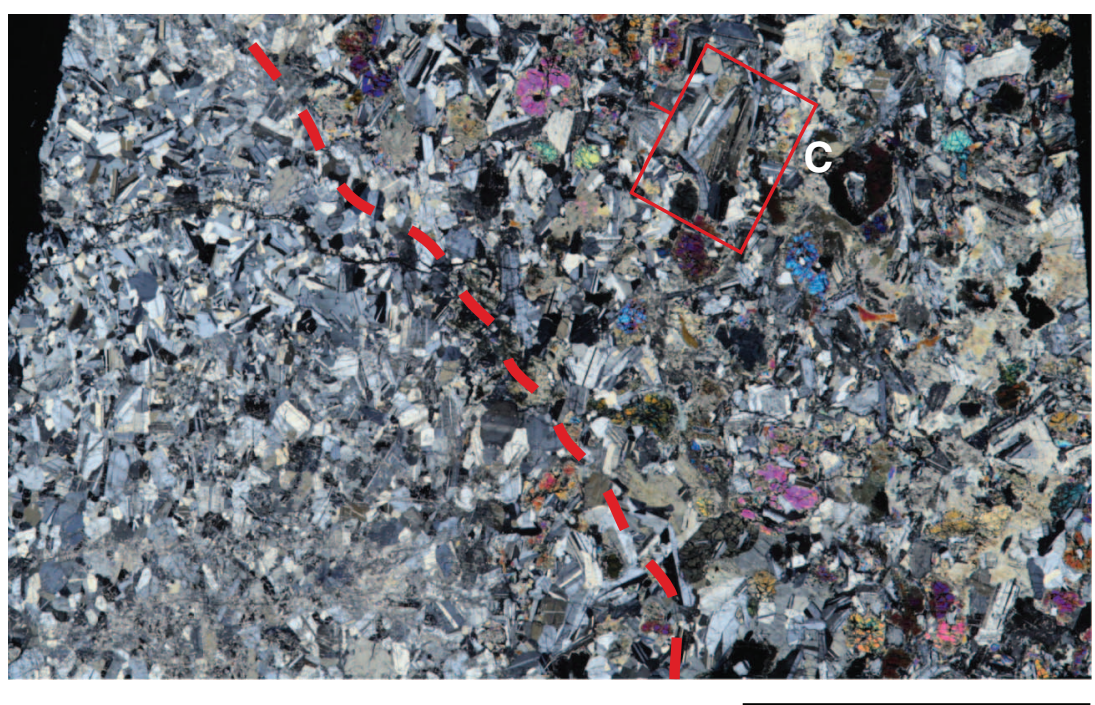

$1 \mathrm{~cm}$
C

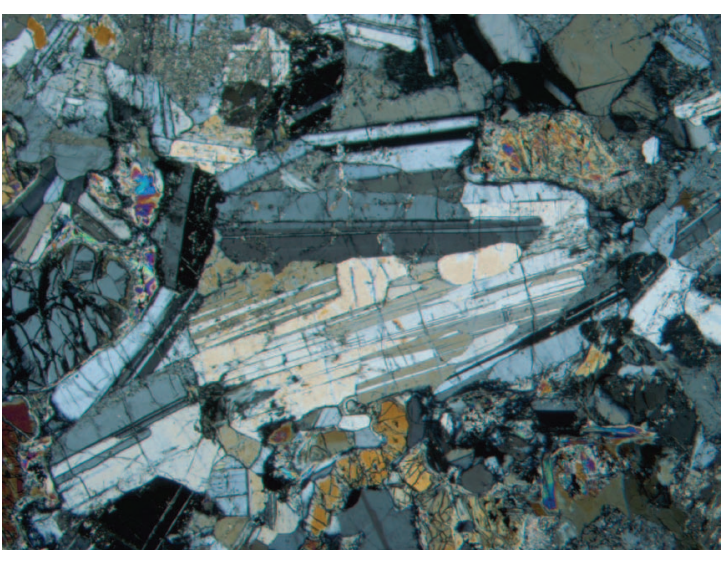

$1 \mathrm{~mm}$
D

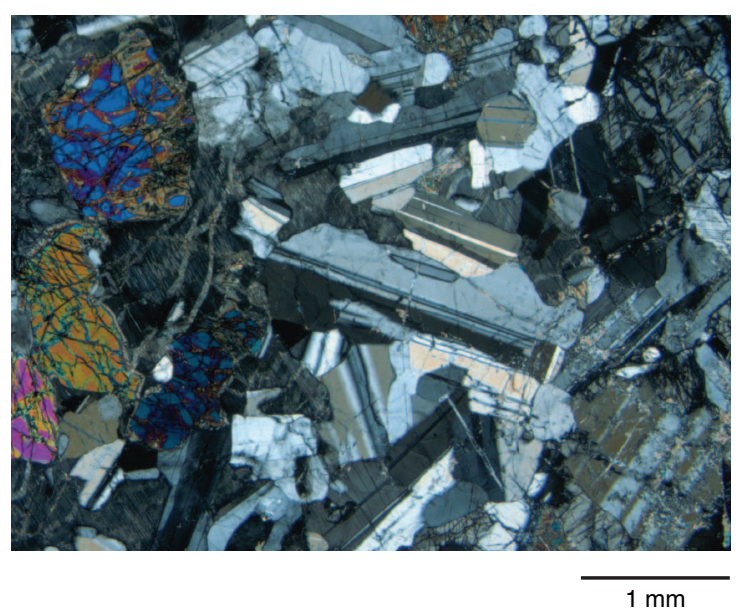


Figure F40. Gabbro with no magmatic foliation (under crossed polars). A. Olivine gabbro with isotropic fabric (Sample 345-U1415P-3R-1, 120-123 cm [Piece 20A]). Red box (tick mark shows upward direction) indicates location of image in C. B. Sutured boundary (red dashed line) between isotropic orthopyroxene-bearing gabbro (left) and olivine-bearing gabbro with weak magmatic foliation (right) (Sample 345-U1415P-4G-1, 10-13 cm [Piece 3]). Red box indicates location of image in D. C. Plagioclase deformation twins, undulose extinction, and locally developed subgrains. D. Deformation twins in a bent plagioclase grain.
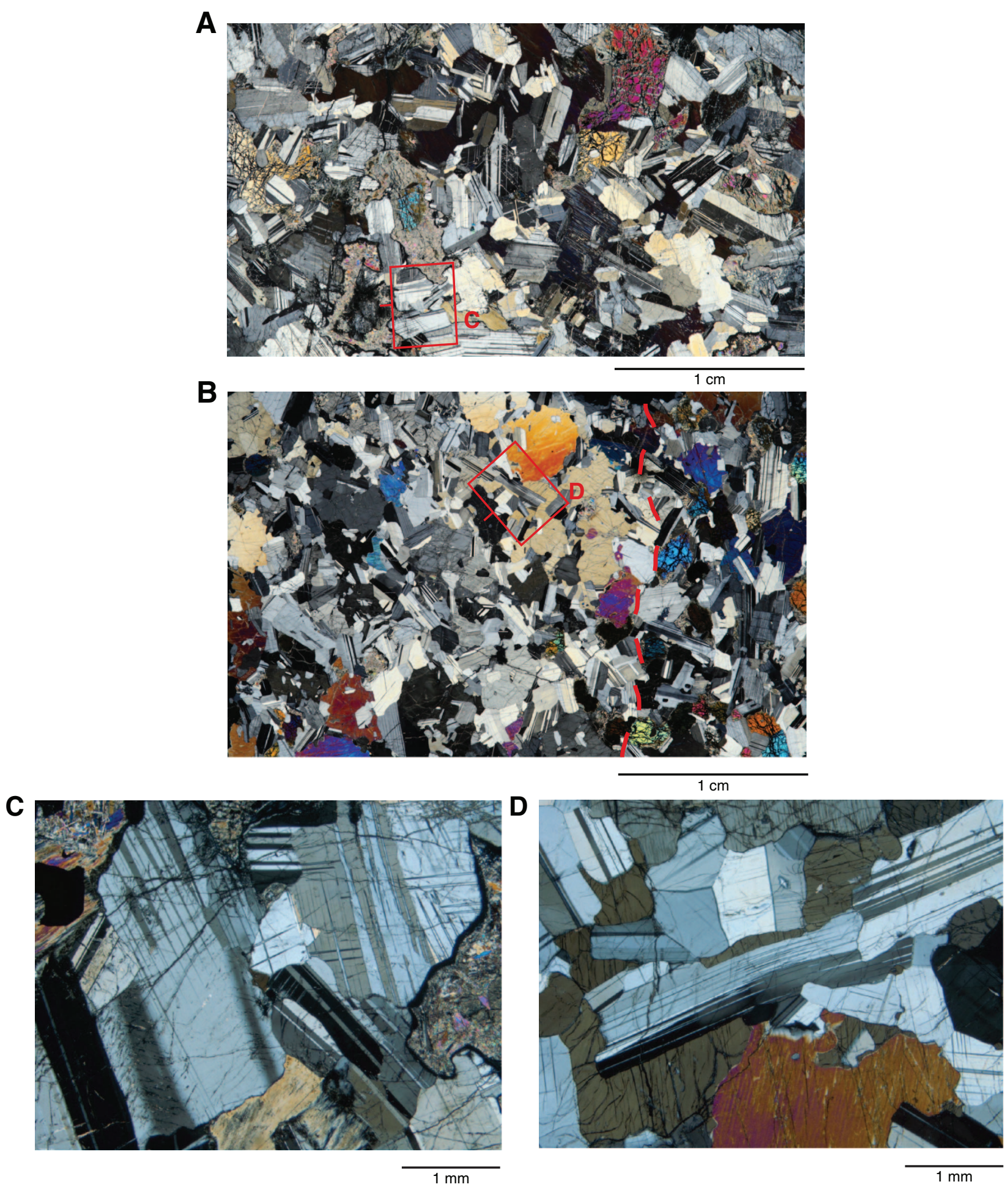
Figure F41. Orthopyroxene and plagioclase vein intruding troctolitic gabbro (Sample 345-U1415P-6R-2, 119$122 \mathrm{~cm}$ [Piece 14]; under crossed polars unless otherwise indicated). A. Dry core image. Red box (tick mark shows upward direction) indicates location of image in B. Plane-polarized light. B. Relatively coarse grained orthopyroxene and plagioclase vein appears to intrude along foliation and truncate grains of troctolitic gabbro. Red boxes indicate location of images C and D. C. Strong foliation defined by plagioclase crystals in olivine gabbro. The plagioclase crystals are elongate and partially annealed with scalloped grain boundaries. D. Strong foliation defined by elongate plagioclase crystals and small skeletal olivine crystals in olivine gabbro.
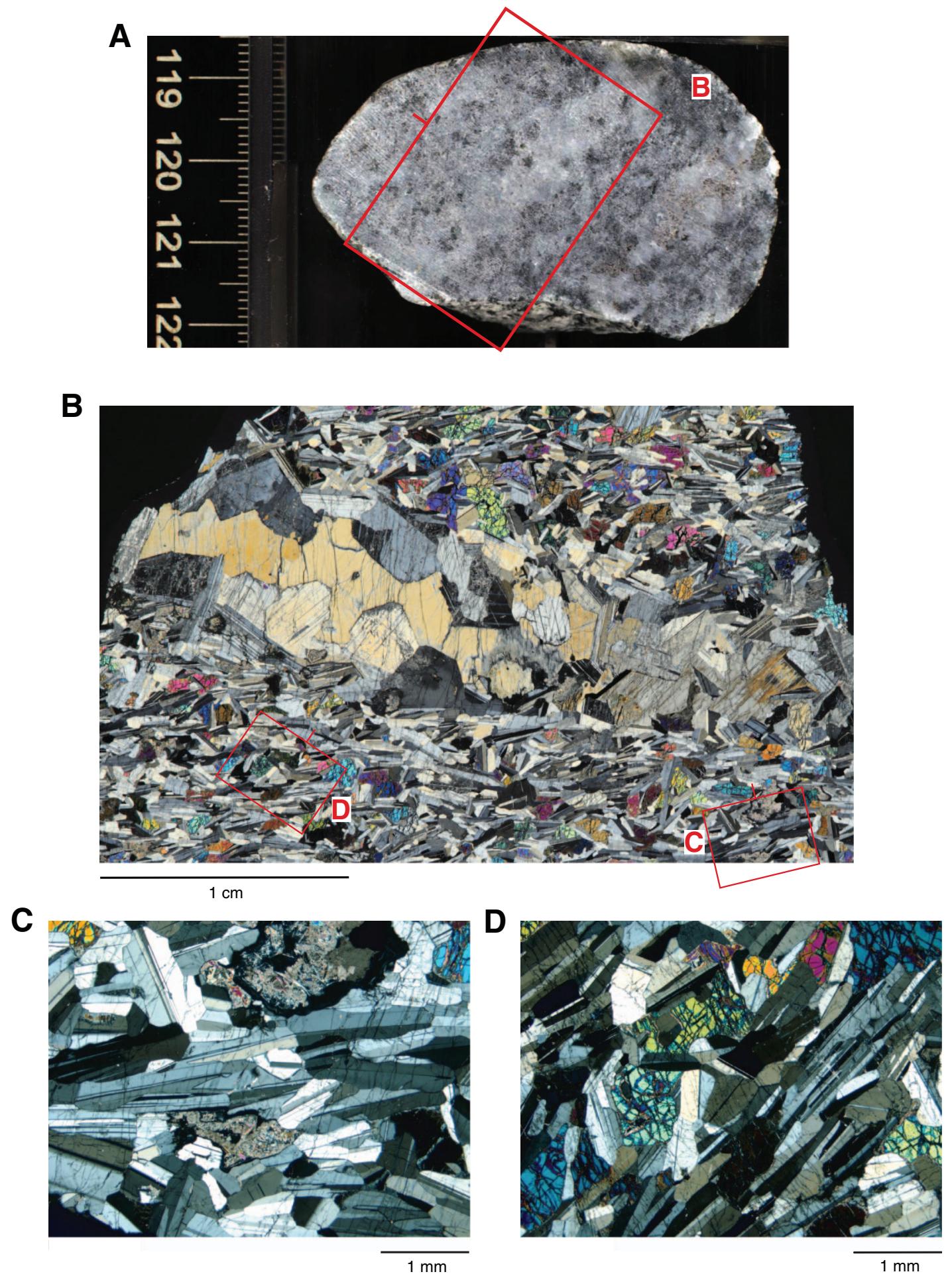
Figure F42. Banding microstructure (under crossed polars). A. Coarse-grained clinopyroxene and olivine band separates fine-grained olivine on the right from a gabbroic layer on the left (Thin section 107; Sample 345U1415P-6R-1, 101-103 cm [Piece 7C]). Red line indicates banding orientation. Red box (tick mark shows upward direction) indicates location of image in C. B. Annealed plagioclase crystals partially enclosed by skeletal olivine (Thin Section 104; Sample 345-U1415P-5R-2, 52-53 cm [Piece 6]). C. Annealed plagioclase and chromite partially enclosed by delicate, skeletal olivines. D. Very fine grained $(\leq 0.05 \mathrm{~mm})$, strongly annealed plagioclase showing little twinning or zoning (Thin Section 109; Sample 345-U1415P-6R-2, 38-41 cm [Piece 4]). E. Distribution of very fine grained $(\leq 0.1 \mathrm{~mm})$ patches of plagioclase hosting deformation twins and curved grain boundaries interior to an orthopyroxene oikocryst (Thin Section 108; Sample 345-U1415P-6R-2, 31-34 cm [Piece 3]).

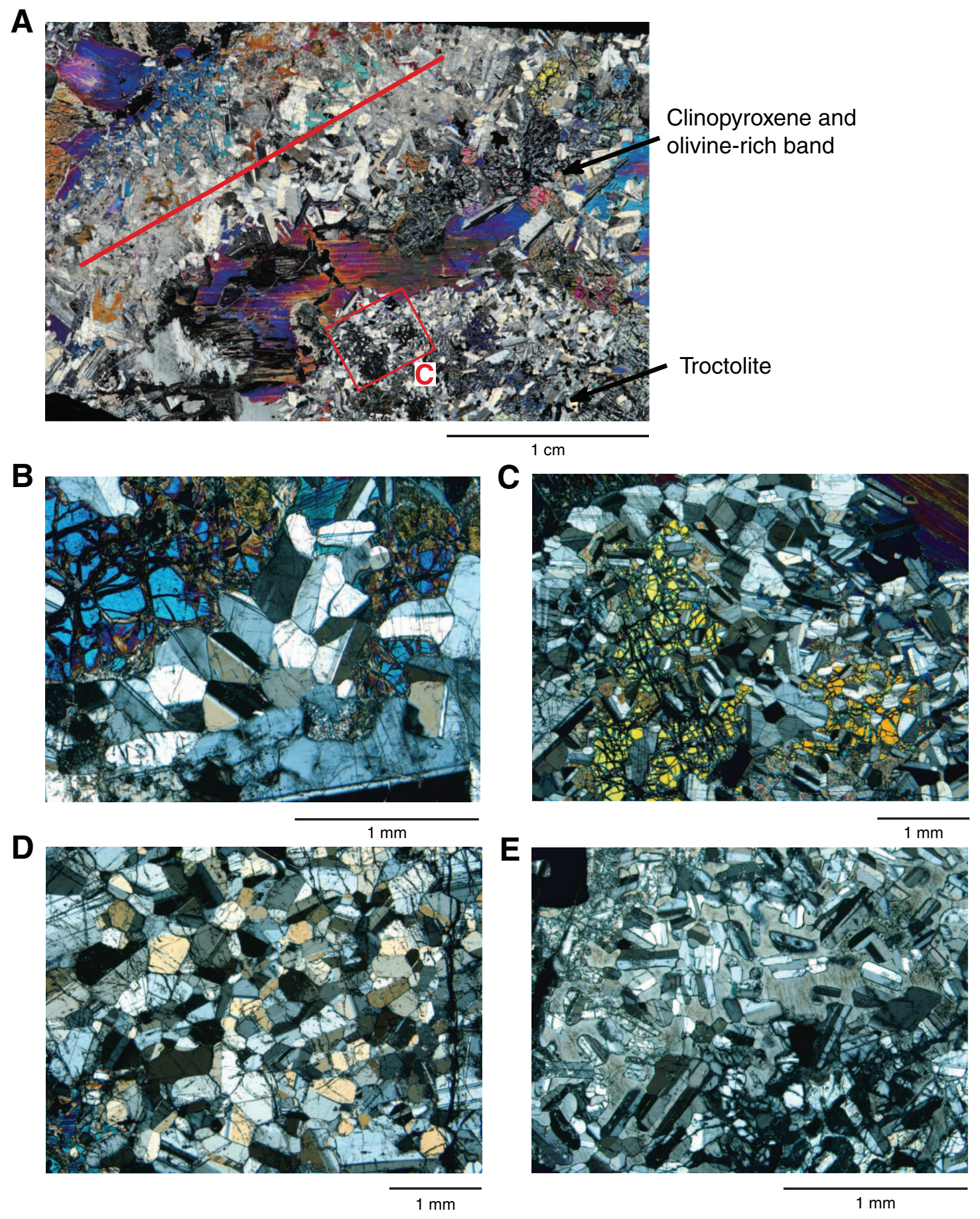


Figure F43. Variations in magmatic texture within troctolite (Unit III in Holes U1415P and U1415J). A. Isotropic fabric (interval 345-U1415P-18R1, 54-71 cm). B. Moderate subvertical foliation defined by plagioclase and olivine shape-preferred orientation (SPO) (interval 345-U1415P-23R-2, 54-71 cm). C. Moderate subvertical foliation defined by plagioclase and olivine SPO (interval 345-U1415J-18R-1, 96-107 cm).

Hole U1415P

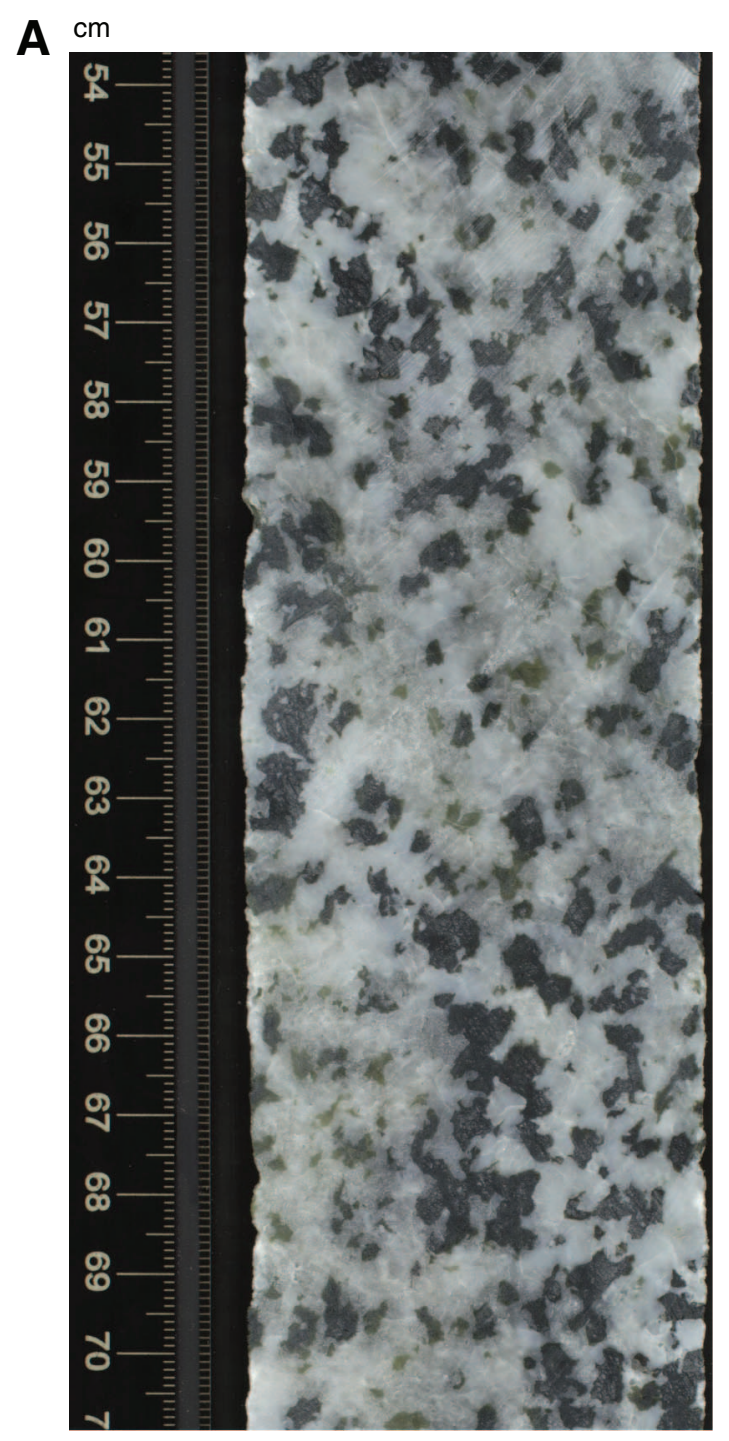

345-U1415P-18R-1

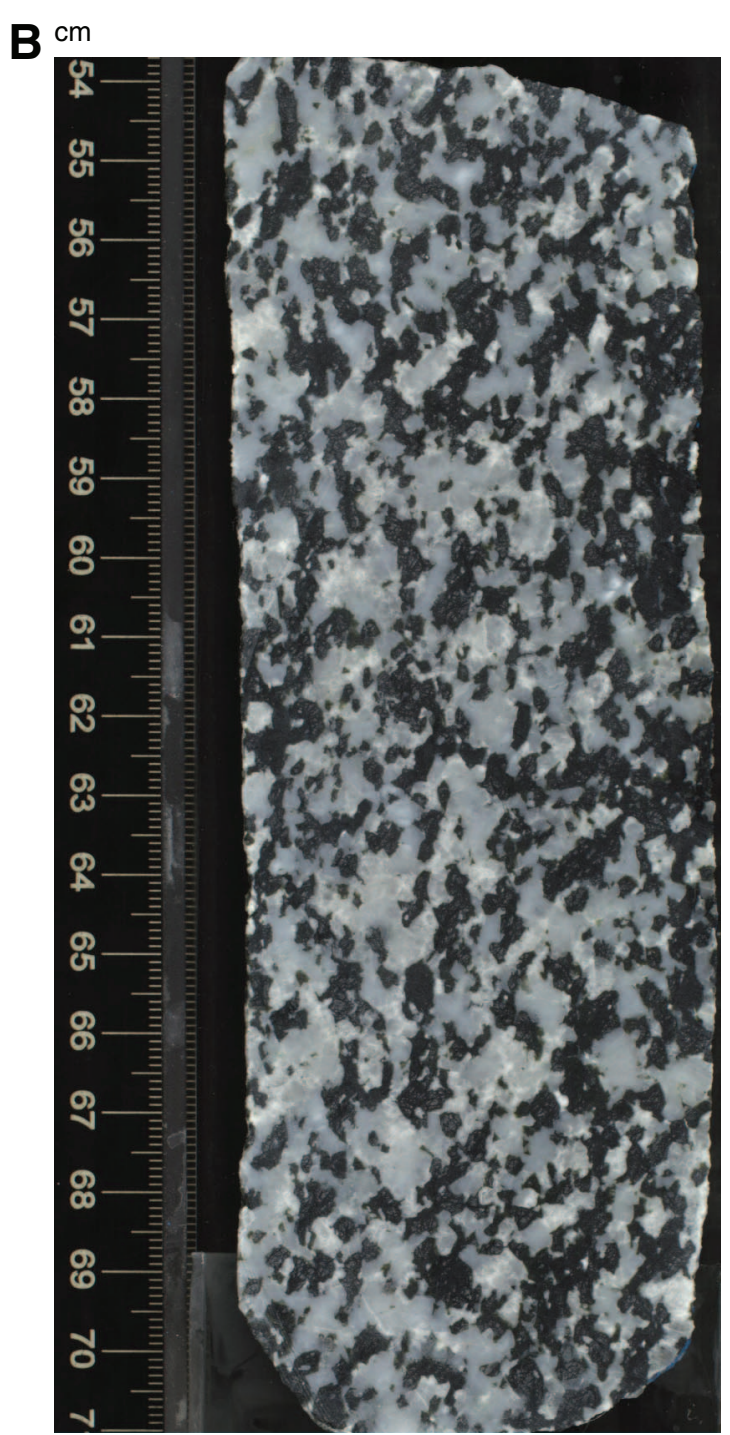

345-U1415P-23R-2
Hole U1415J

C $\mathrm{cm}$

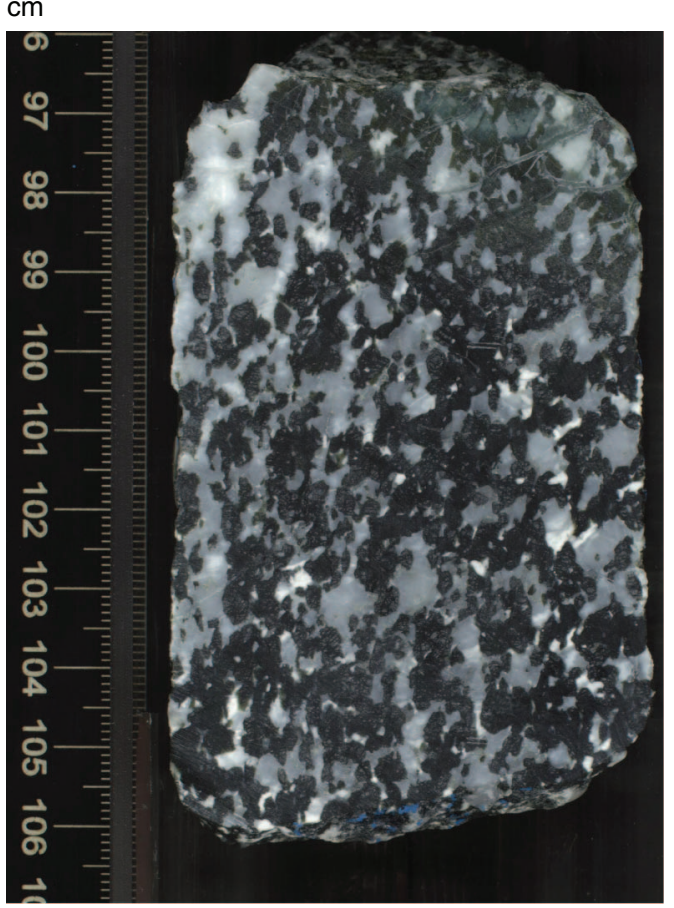

345-U1415J-18R-1 
Figure F44. Discordant intrusive contacts between relatively fine grained olivine gabbro and troctolite. A. Moderately well foliated olivine gabbro (Sample 345-U1415P-3R-1, 30-34 cm [Piece 7]). Red box indicates location of image in D. B. Intrusive contact between orthopyroxene-bearing olivine gabbro (top) and troctolite (bottom). The contact truncates both olivine grains in the troctolite and is discordant to the steeply dipping olivine foliation in the same unit (Sample 345-U1415P-18R-1, 78-83 cm [Piece 7]). Red box indicates location of image in E. C. Altered contact between olivine gabbro (bottom) and troctolite (top). The boundary between troctolite and olivine gabbro truncates steeply dipping olivine foliation and individual olivine grains in the troctolite (Sample 345-U1415P-22R-2, 103-112 cm [Piece 8]). Red box indicates location of image in F. D. Moderate magmatic foliation of olivine gabbro defined by a plagioclase shape-preferred orientation (SPO) that wraps locally around relatively large clinopyroxene crystals (Thin Section 96; 345-U1415P-3R-1, 31-34 $\mathrm{cm}$ [Piece 7]). Red boxes indicate location of Figures F45A-F45C. E. Moderate magmatic foliation defined by plagioclase SPO that parallels the contact between orthopyroxene-bearing olivine gabbro and troctolite (Thin Section 130; 345-U1415P-16R-1, 117-120 cm [Piece 10]). Red boxes indicate location of Figures F45E and F45F. F. Contact between olivine gabbro and troctolite shown in C (Thin Section 140; 345-U1415P-22R-2, $113-115 \mathrm{~cm}$ [Piece8]). Red box (with tick mark showing up) indicates the location of image in Figure F45D. D$\mathrm{F}$ are under crossed polars.

A

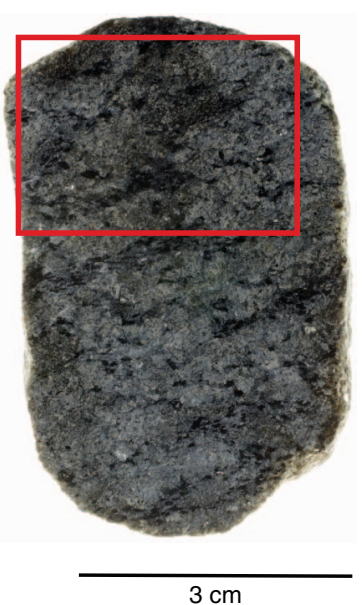

B

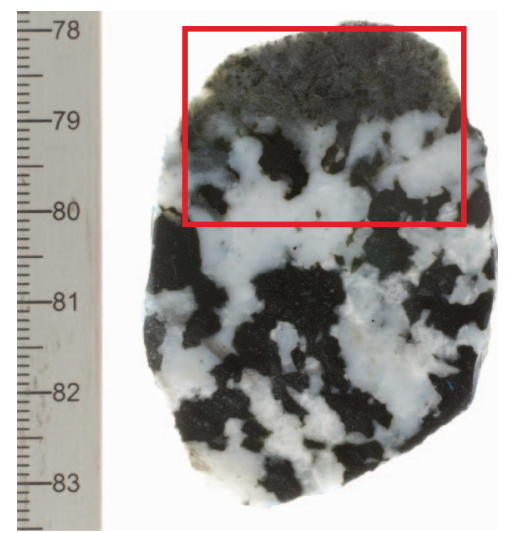

C

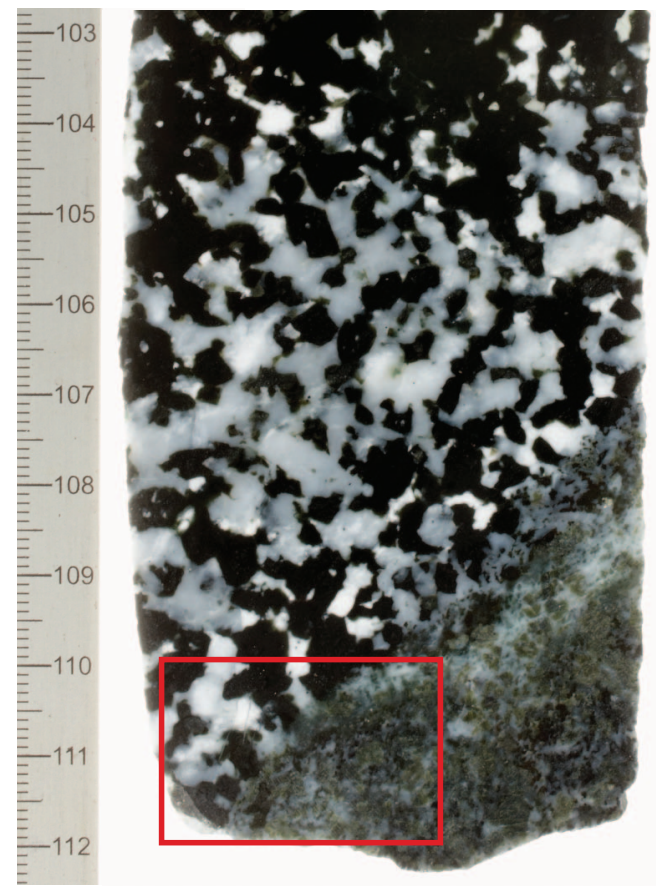

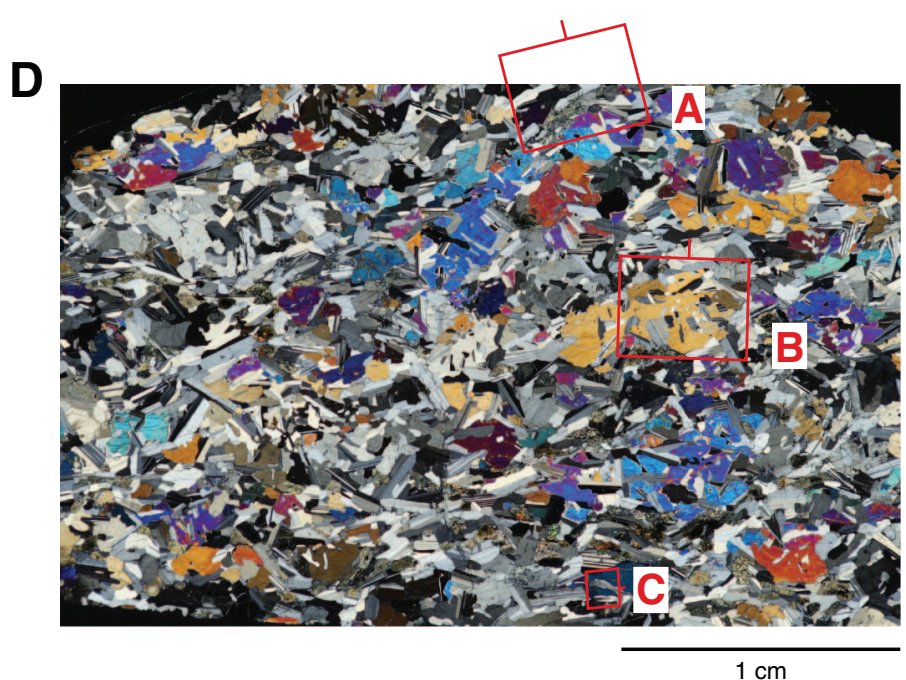

E

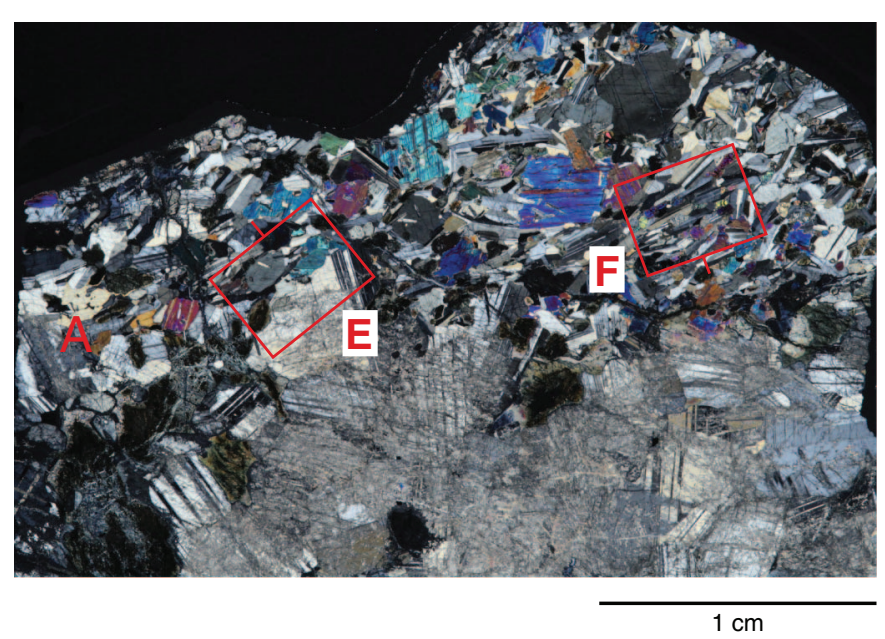

$\mathbf{F}$

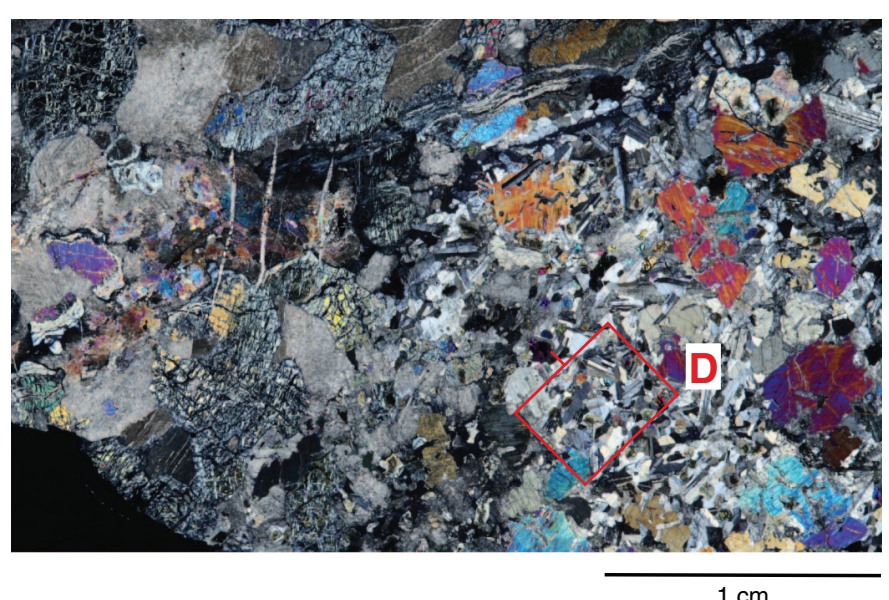


Figure F45. Details of intrusive contacts (under crossed polars). A-C. Thin Section 96 (Sample 345-U1415P-3R1, 31-34 cm [Piece 7]); reference images in Figures F44A and F44D. (A) Plagioclase and olivine crystals defining the moderate magmatic foliation of olivine gabbro. (B) Amoeboid clinopyroxene oikocryst locally showing subgrain development in olivine gabbro. (C) Clinopyroxene crystal hosting an elongate and deformed plagioclase crystal in olivine gabbro. D. Isotropic fabric in olivine gabbro (Thin Section 140; Sample 345-U1415P-22R2, 110-112 cm [Piece 8]); reference images in Figures F44C and F44F. E. Plagioclase crystals in the orthopyroxene-bearing olivine gabbro paralleling the contact with troctolite shown in Figures F44B and F44E. F. Plagioclase crystals defining the foliation in orthopyroxene-bearing olivine gabbro (Thin Section 130; Sample 345U1415P-18R-1, 78-80 cm [Piece 7]) shown in Figures F44B and F44E.

A

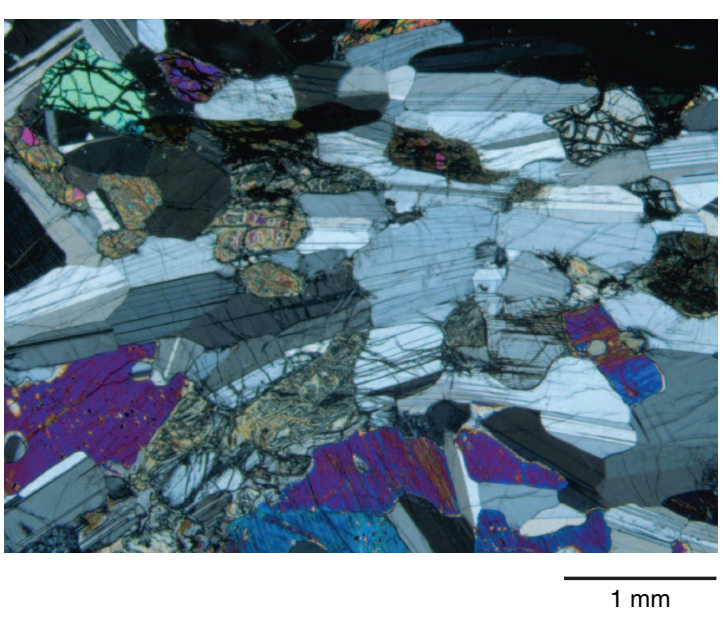

C

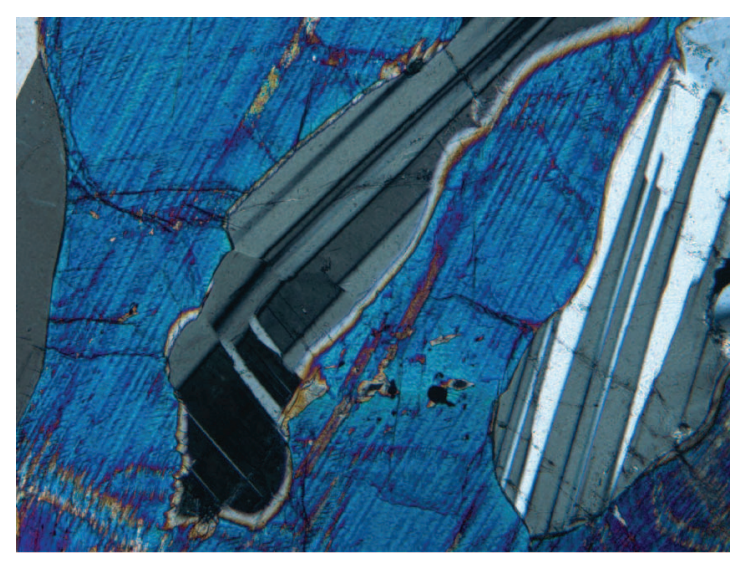

$1 \mathrm{~mm}$

E

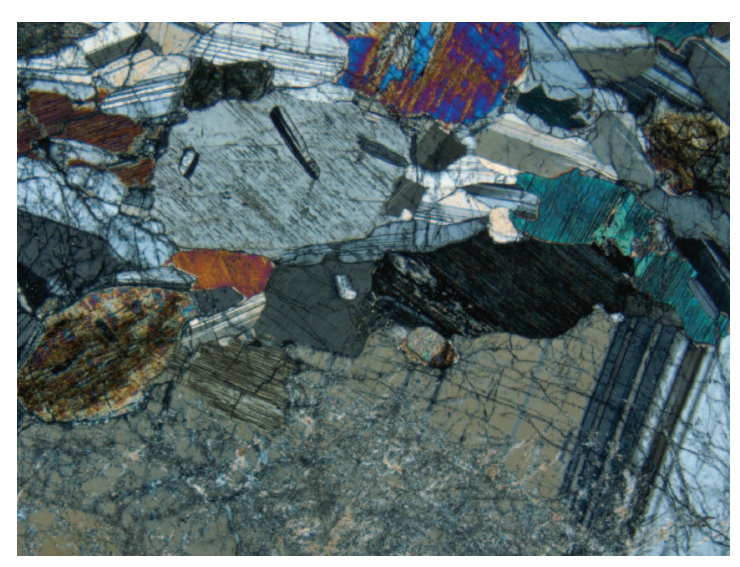

B

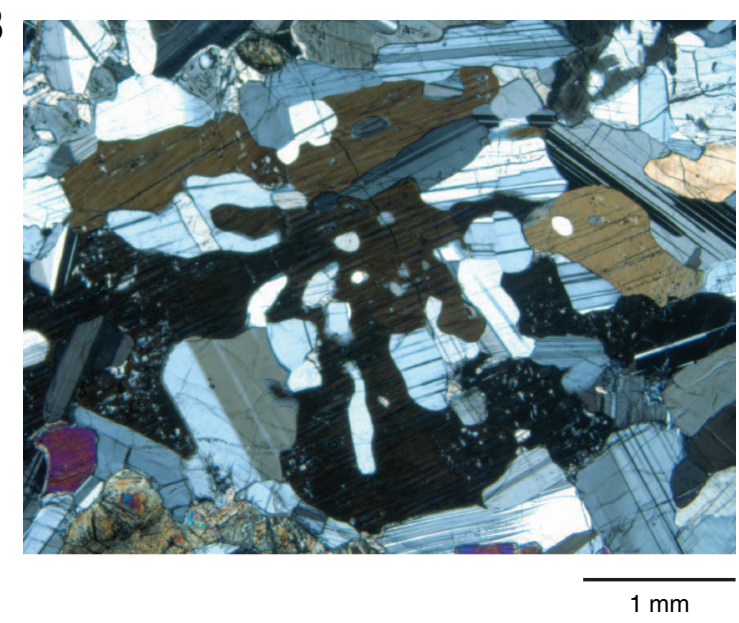

D

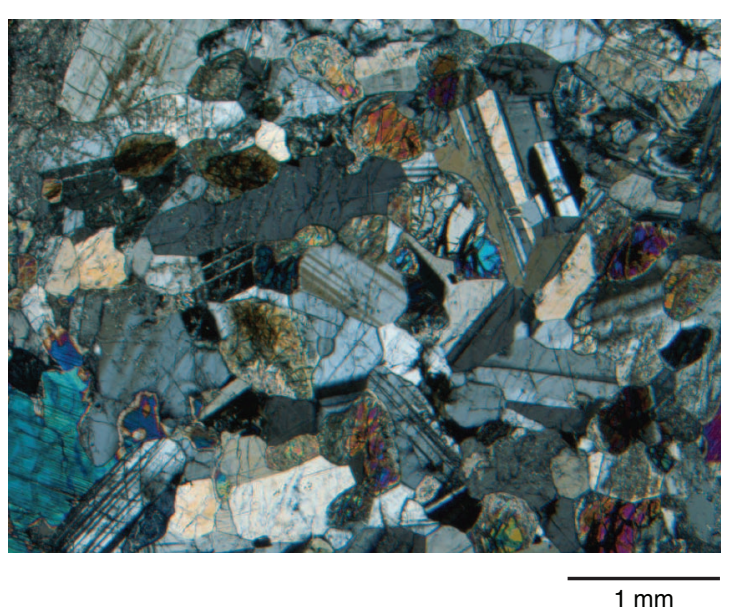

F

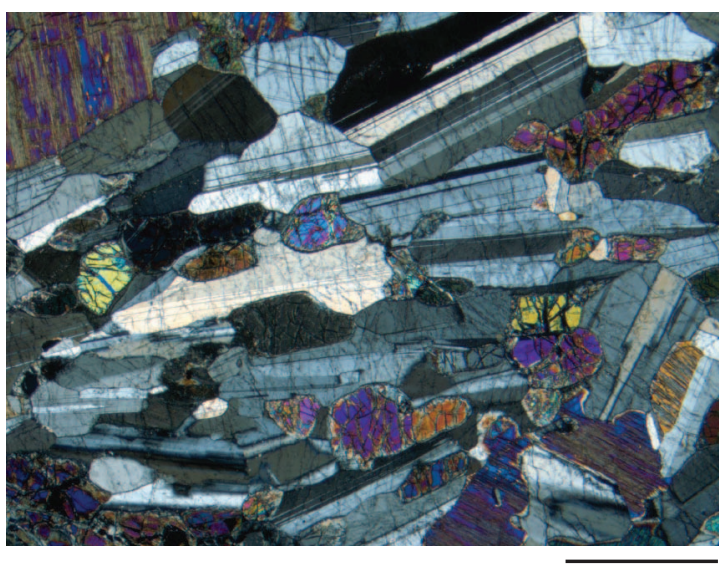


Figure F46. Brittle structures in Unit II (Thin Section 121; Sample 345-U1415P-10R-1, 121-134 cm [Piece 13]). A. Character of cataclasite. B. Cataclasite (under crossed polars). C. Zone of ultracataclasite (plane-polarized light).

A

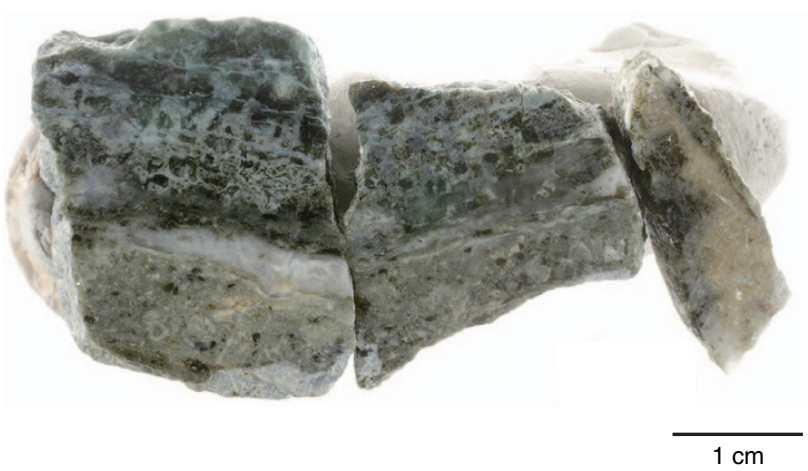

B

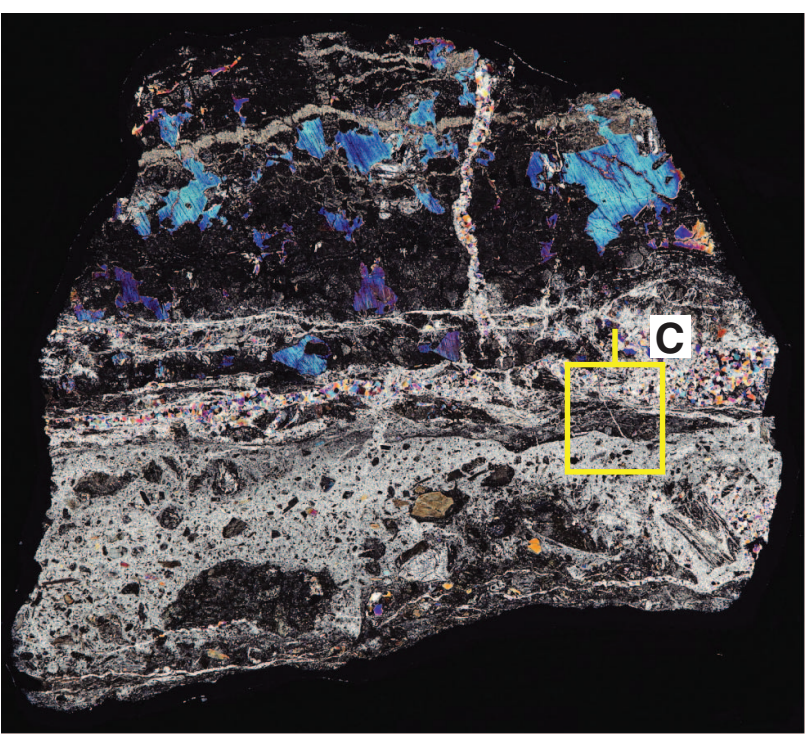

$1 \mathrm{~cm}$

C

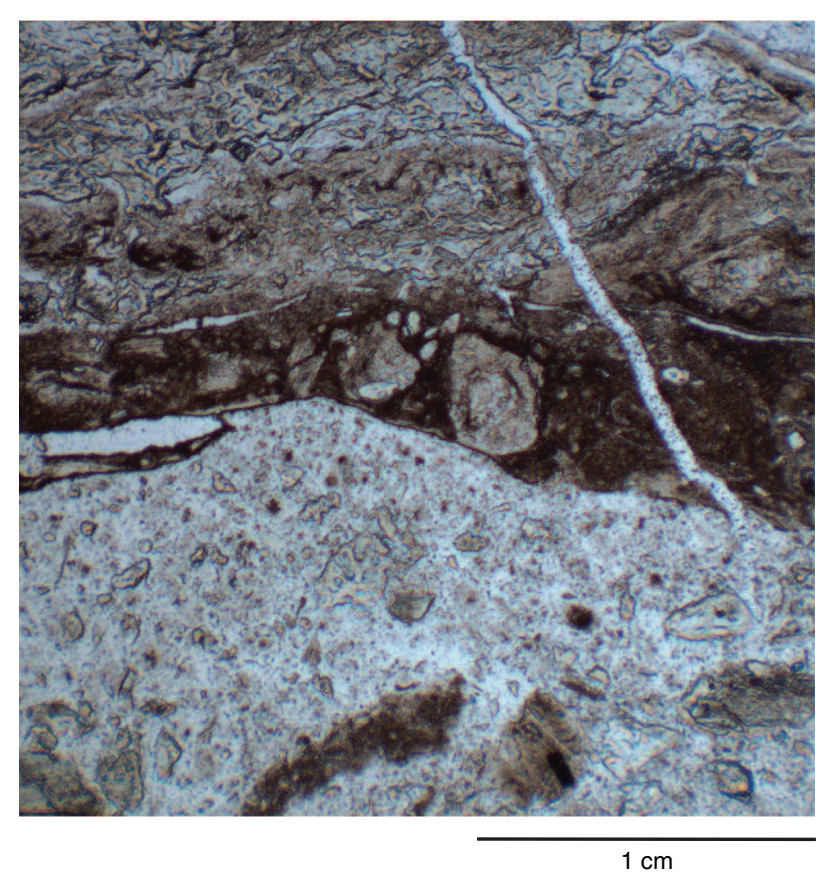


Figure F47. Brittle microstructures in Unit III (Thin Section 129; Sample 345-U1415P-16R-1, 47-49 cm [Piece 6]; under crossed polars). A. Sheared chlorite vein with carbonate in troctolite. Yellow box (tick mark shows upward direction) indicates location of B. B. Oriented carbonate in sheared chlorite vein.
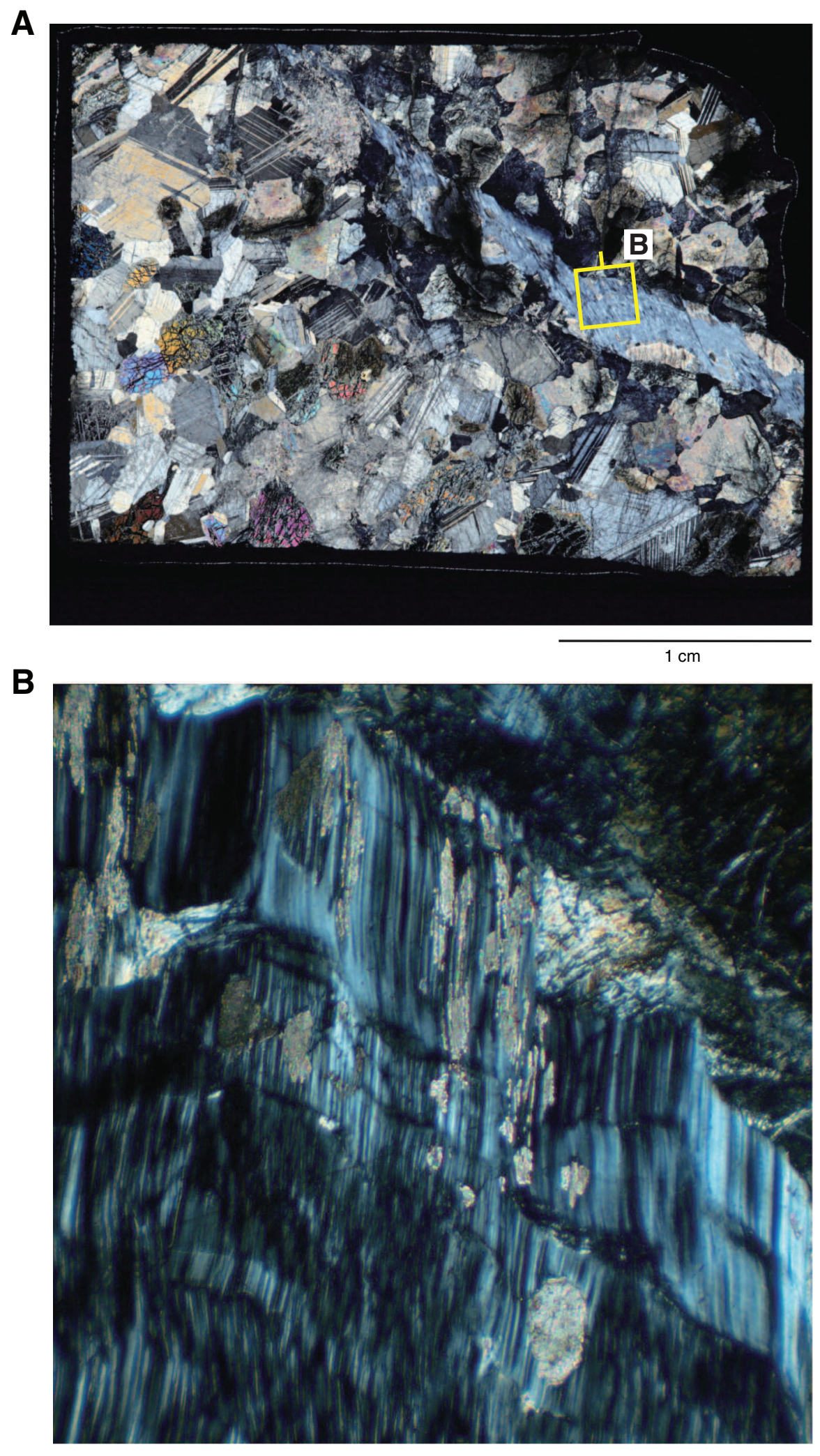

$1 \mathrm{~mm}$ 
Figure F48. Vein density expressed as percentage of core length, Hole U1415P.

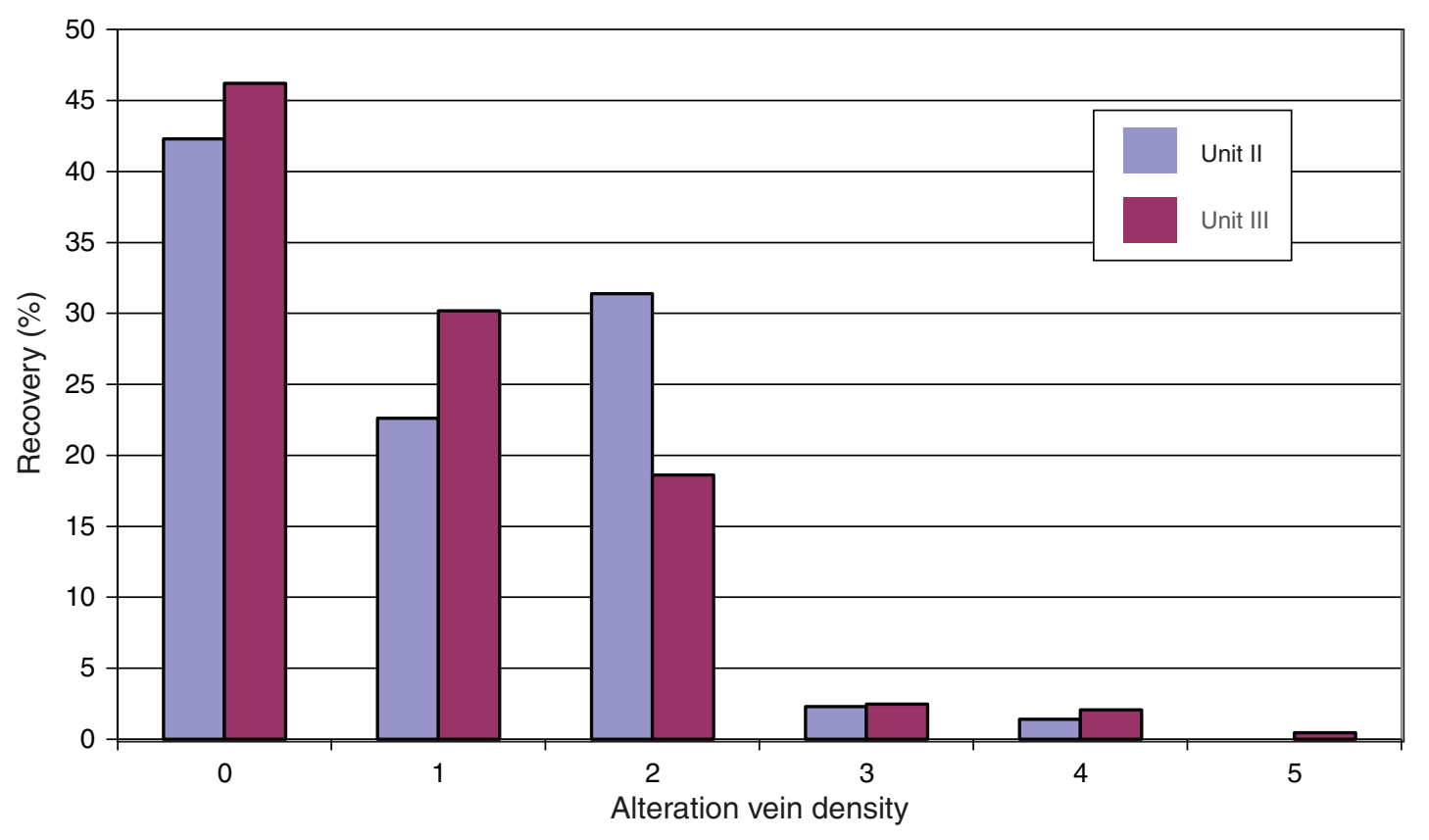


Figure F49. Alteration front at the top of a troctolite piece (Sample 345-U1415P-23R-1, 105-116 cm [Piece 15]).

$\mathrm{cm}$

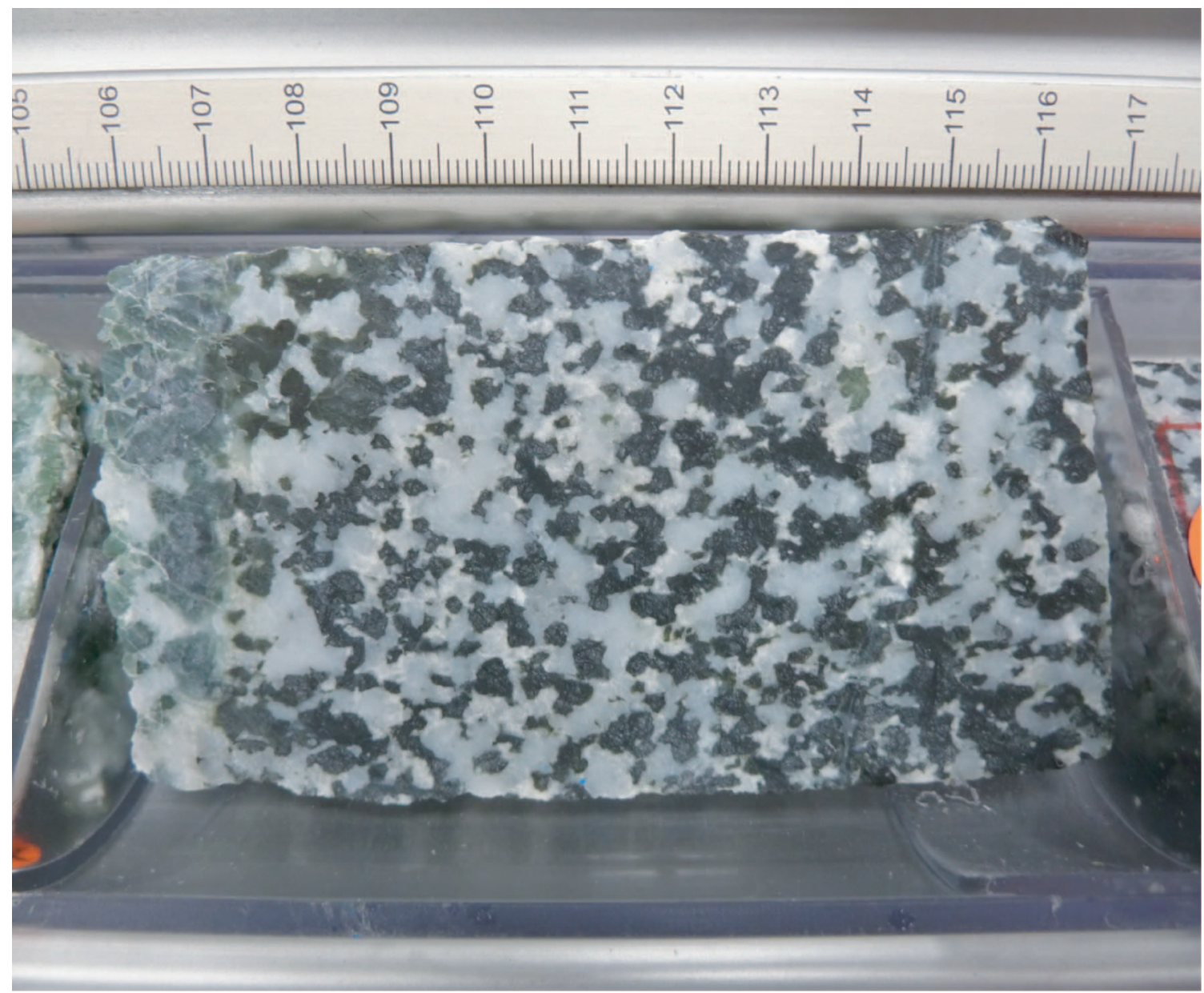


Figure F50. Measured vein dip in Units II and III and entire Hole U1415P.

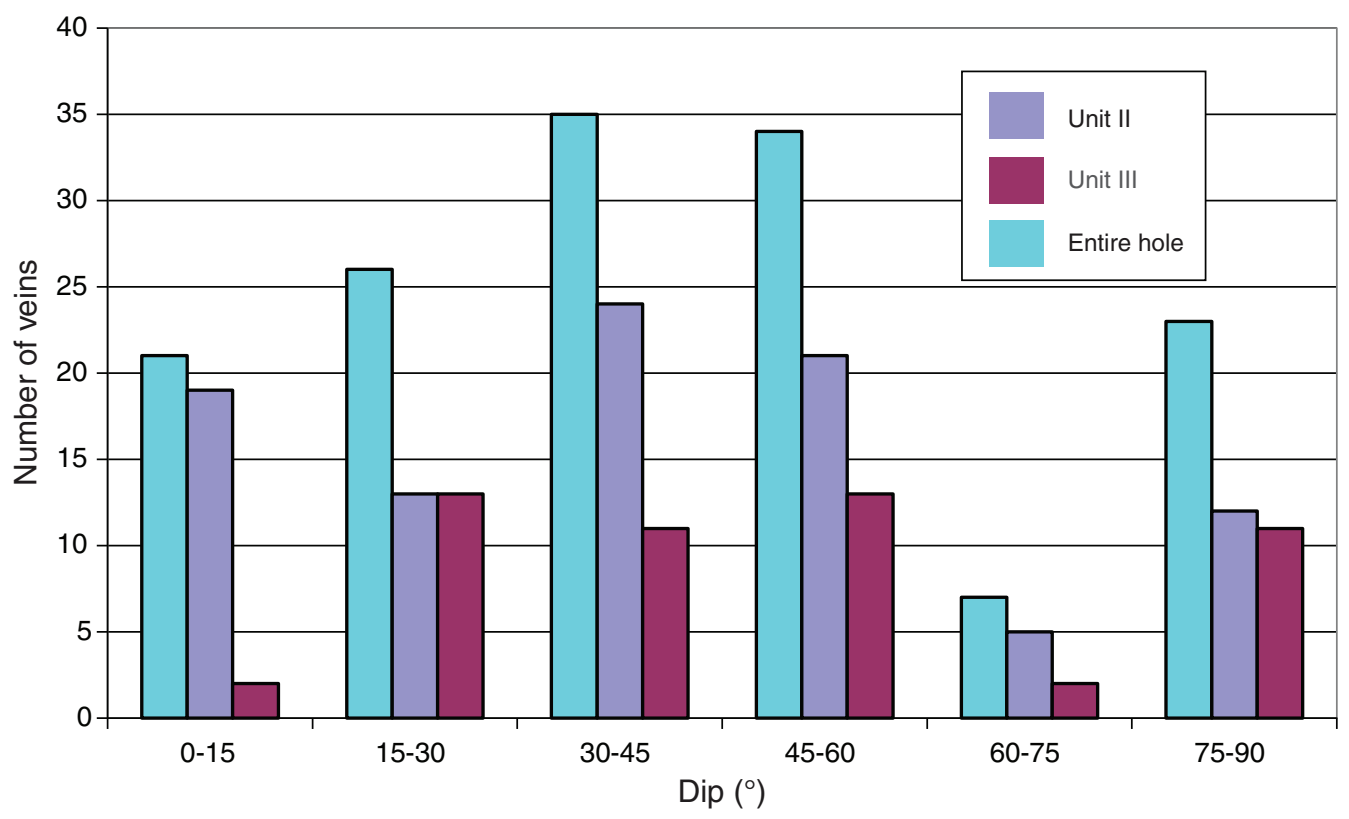


Figure F51. Core recovery and vein type, location, and measured dip, Hole U1415P.
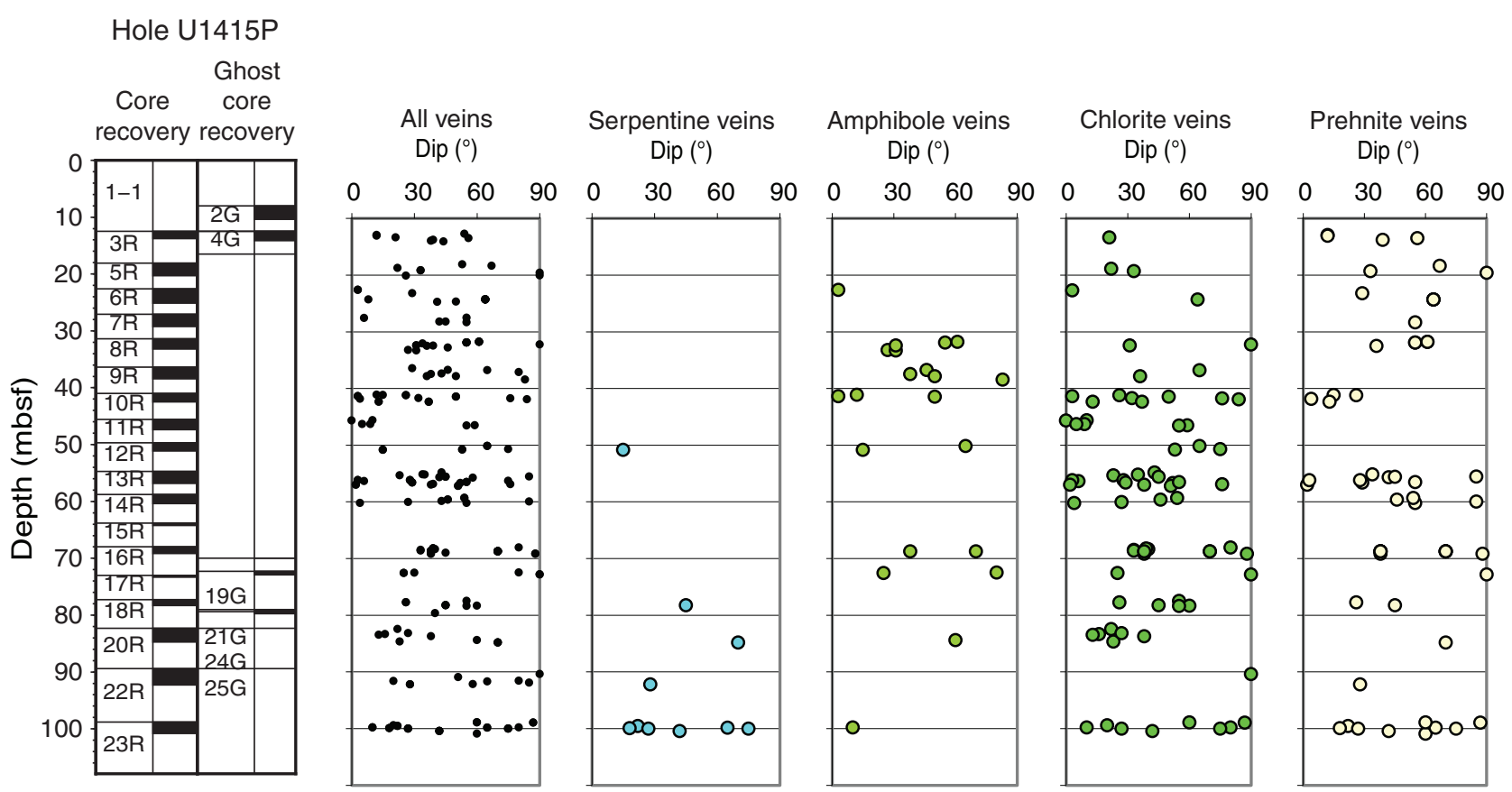

Zeolite veins
Dip $\left(^{\circ}\right)$
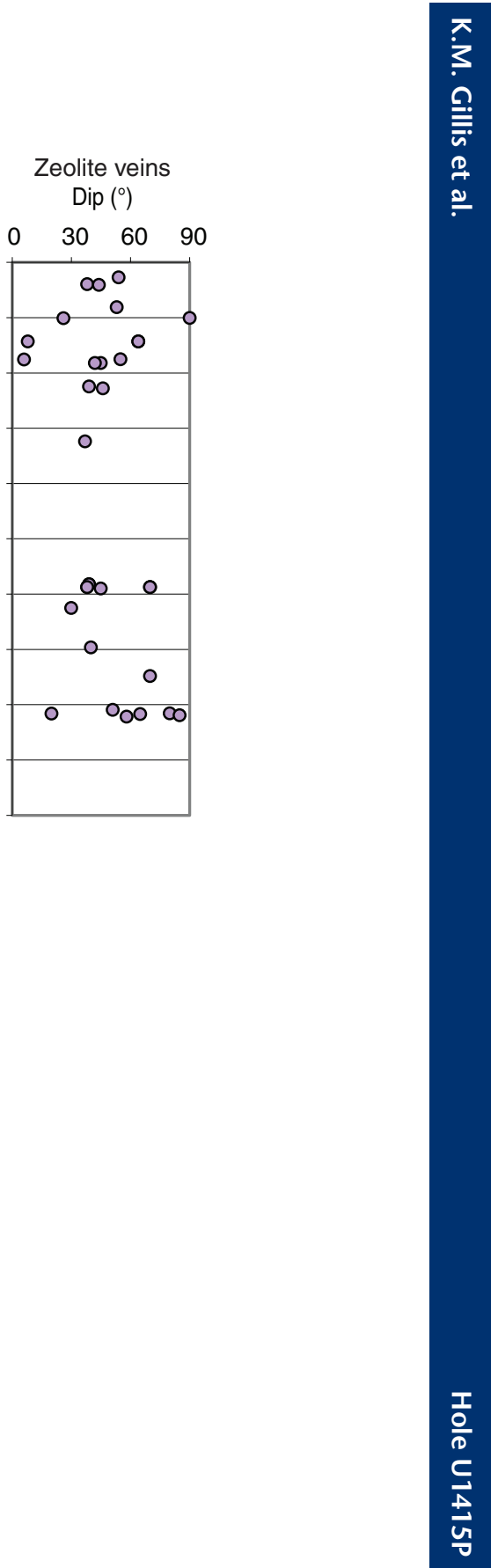
Figure F52. Natural remanent magnetization (NRM) intensity for gabbroic and troctolitic rocks from Hole U1415P based on archive-half core remanence measurements.
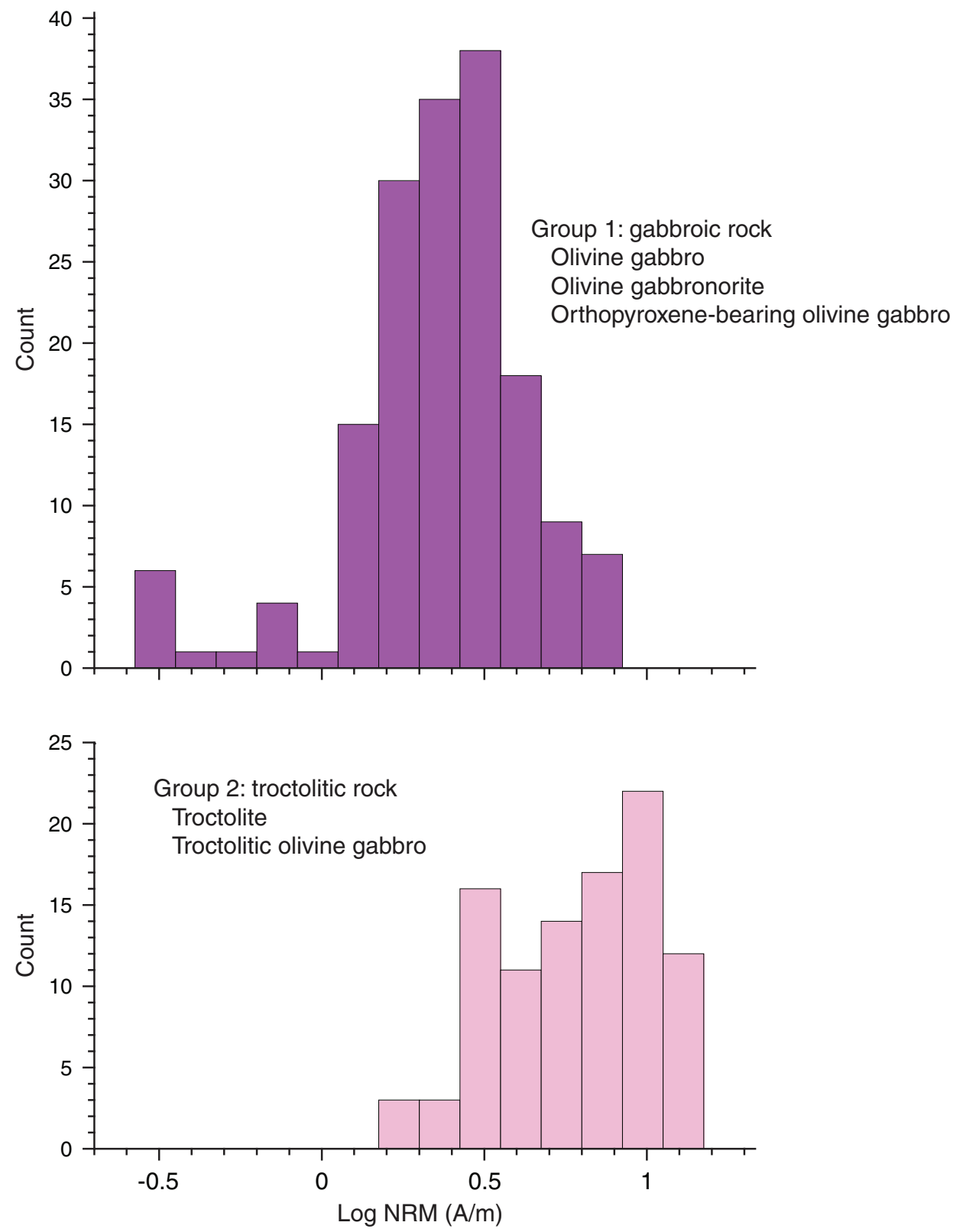
Figure F53. Representative examples of alternating field demagnetization of archive-half core pieces, Hole U1415P. Solid circles $=$ projection onto the horizontal plane, open circles = projection onto the vertical $\mathrm{X}-\mathrm{Z}$ plane. $\mathrm{NRM}=$ natural remanent magnetization, $\mathrm{ARM}=$ anhysteretic remanent magnetization.

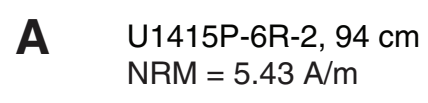
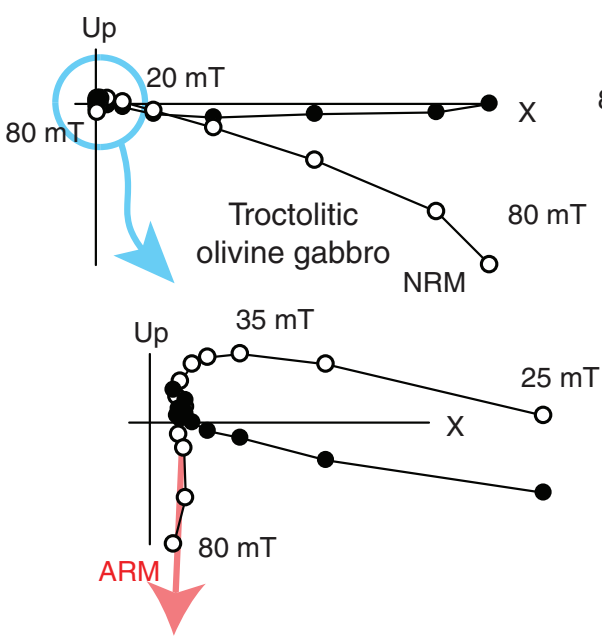

E

U1415P-20R-2, $6 \mathrm{~cm}$ $\mathrm{NRM}=9.33 \mathrm{~A} / \mathrm{m}$

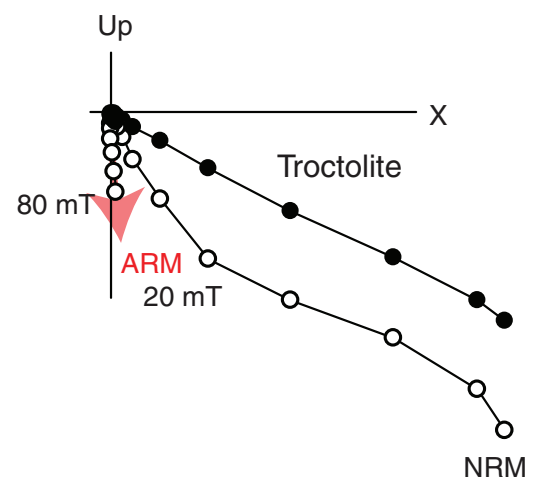

G U1415P-14R-2, $34 \mathrm{~cm}$ $\mathrm{NRM}=757 \mathrm{~mA} / \mathrm{m}$

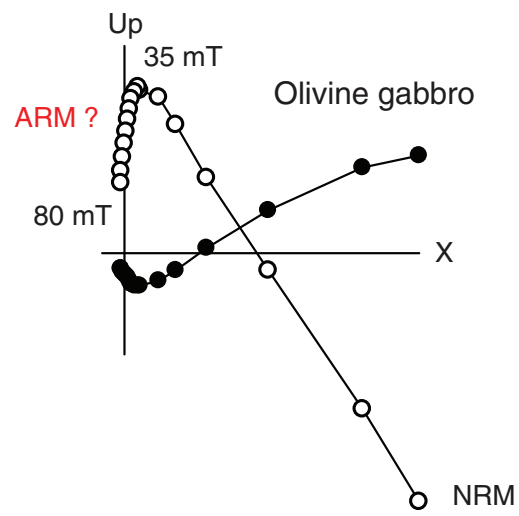
B U1415P-16R-1, $96 \mathrm{~cm}$ $\mathrm{NRM}=4.12 \mathrm{~A} / \mathrm{m}$

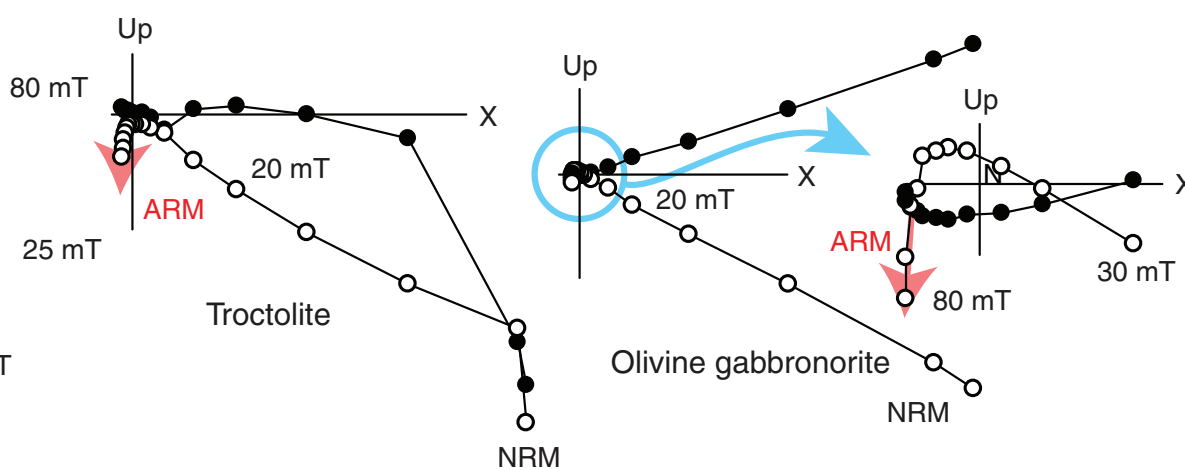
C U1415P-4G-1, $76 \mathrm{~cm}$ $\mathrm{NRM}=2.77 \mathrm{~A} / \mathrm{m}$

D U1415P-5R-2, $58 \mathrm{~cm}$ $\mathrm{NRM}=2.64 \mathrm{~A} / \mathrm{m}$

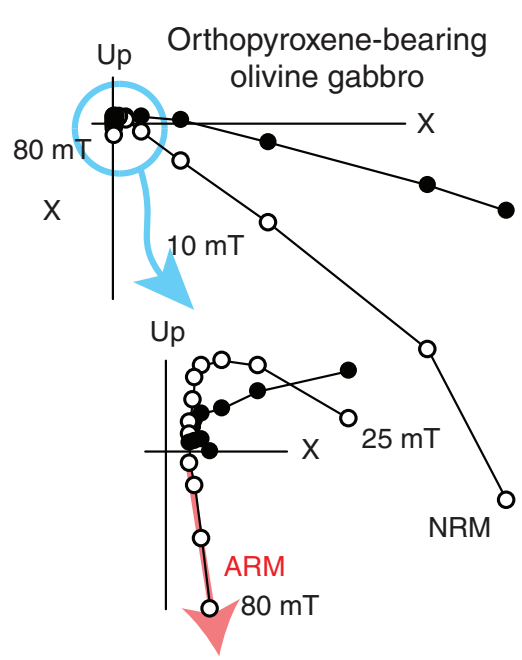

F U1415P-22R-1, $88 \mathrm{~cm}$ $\mathrm{NRM}=7.40 \mathrm{~A} / \mathrm{m}$

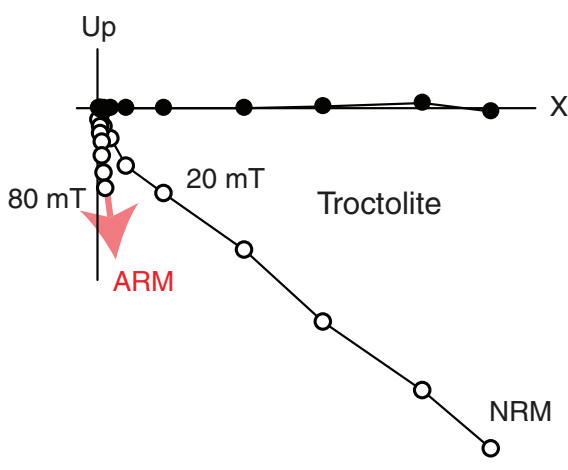

H U1415P-14R-2, $12 \mathrm{~cm}$ $\mathrm{NRM}=456 \mathrm{~mA} / \mathrm{m}$

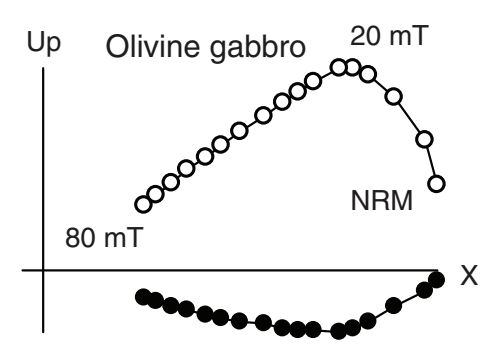


Figure F54. A-D. Archive-half core magnetic measurements, Hole U1415P. For inclination and intensity, open circles are natural remanent magnetization (NRM) data and solid circles are principal component analysis picks. Point magnetic susceptibility was measured on the Section Half Multisensor Logger. Remanence and susceptibility data from within $4.5 \mathrm{~cm}$ of piece ends were excluded.
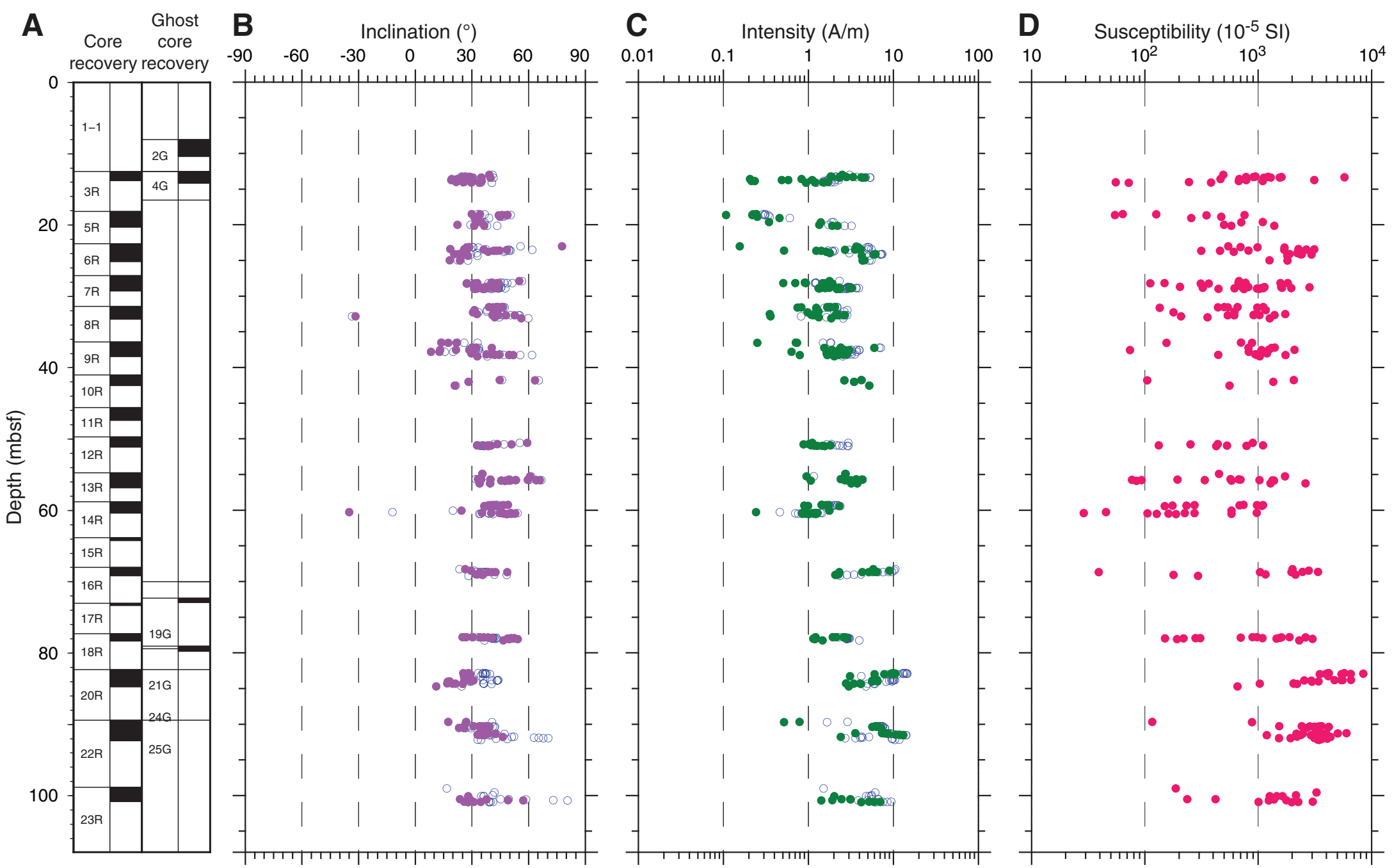
Figure F55. Typical examples of demagnetization behavior in discrete samples, Hole U1415P. Solid circles = projection onto the horizontal plane, open circles $=$ projection onto either the vertical X-Z or Y-Z planes. NRM = natural remanent magnetization, Opx $=0$ orthopyroxene, LTD1 $=$ first low-temperature demagnetization treatment.

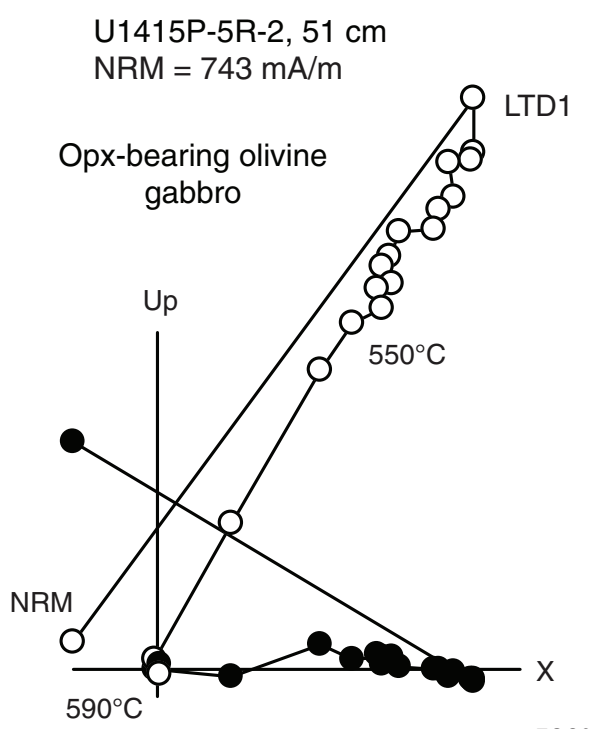

$590^{\circ} \mathrm{C}$

$$
\begin{aligned}
& \text { U1415P-6R-2, } 92 \mathrm{~cm} \\
& \mathrm{NRM}=906 \mathrm{~mA} / \mathrm{m}
\end{aligned}
$$

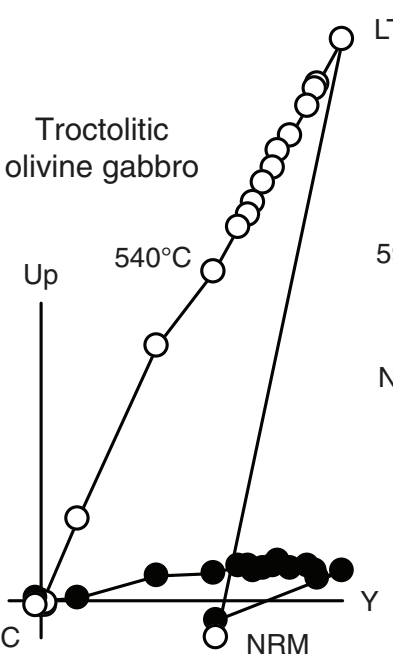

U1415P-14R-2, $21 \mathrm{~cm}$ $\mathrm{NRM}=650 \mathrm{~mA} / \mathrm{m}$

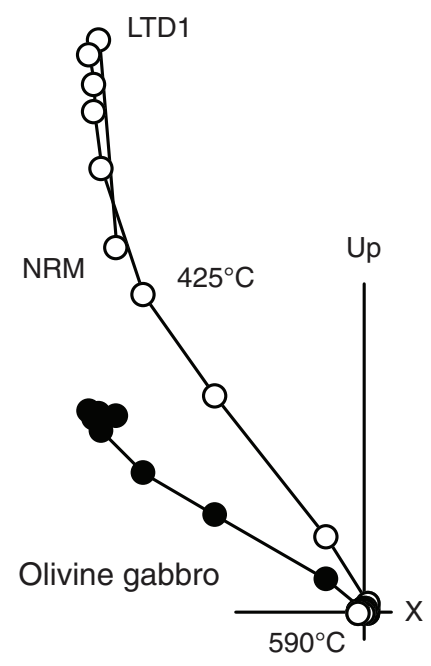

U1415P-20R-2, $58 \mathrm{~cm}$ $\mathrm{NRM}=2.47 \mathrm{~A} / \mathrm{m}$<smiles>[Te]</smiles>

Troctolite

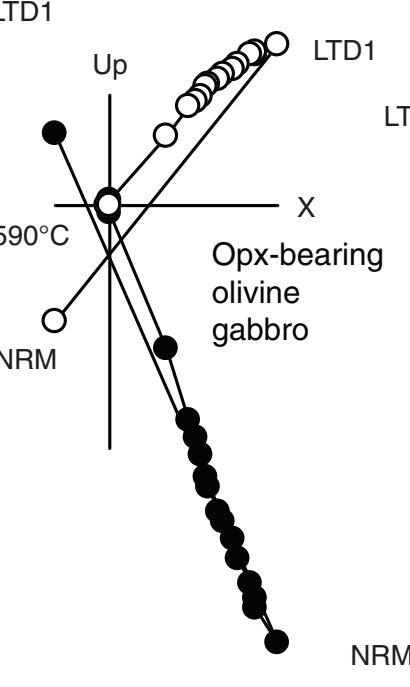

U1415P-22R-2, $32 \mathrm{~cm}$ $\mathrm{NRM}=2.51 \mathrm{~A} / \mathrm{m}$

Up $450^{\circ} \mathrm{C}$

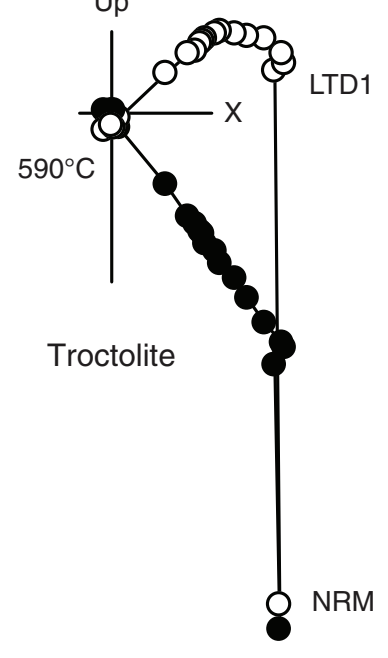

U1415P-9R-1, $6 \mathrm{~cm}$ $\mathrm{NRM}=780 \mathrm{~mA} / \mathrm{m}$

U1415P-12R-1, $7 \mathrm{~cm}$ $\mathrm{NRM}=1.30 \mathrm{~A} / \mathrm{m}$

Olivine gabbro
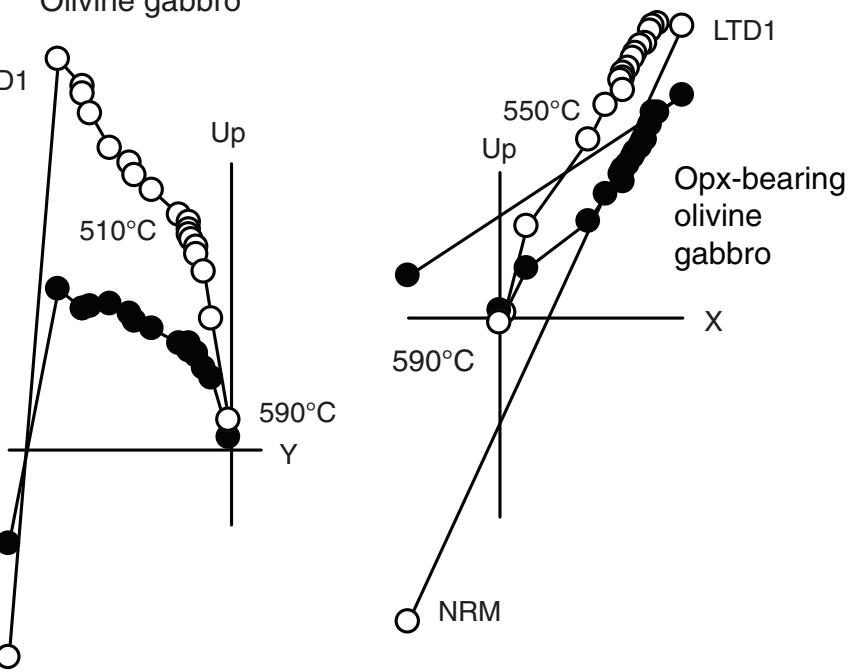

U1415P-23R-1, $68 \mathrm{~cm}$ $\mathrm{NRM}=3.17 \mathrm{~A} / \mathrm{m}$

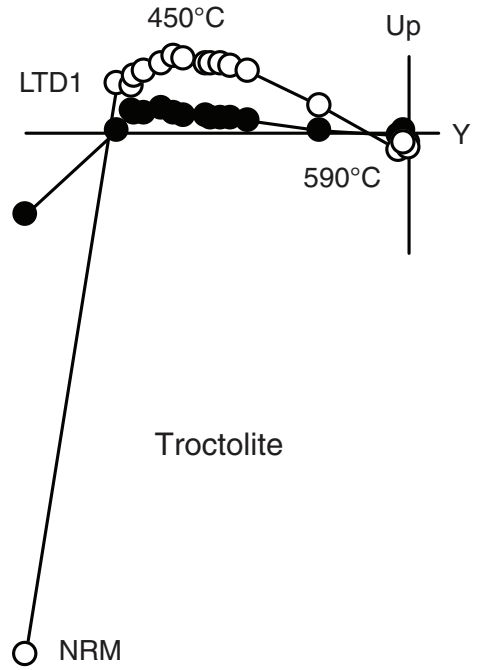


Figure F56. Normalized thermal demagnetization intensity decay curves for discrete samples, Hole U1415P. A. Samples with discrete, high unblocking temperature spectra ( $70 \%$ of remanence lost within $40^{\circ} \mathrm{C}$ of the magnetite Curie temperature). B. Samples with lower unblocking temperature spectra and/or inflections in the demagnetization decay curves at temperatures between $400^{\circ}$ and $500^{\circ} \mathrm{C}$.
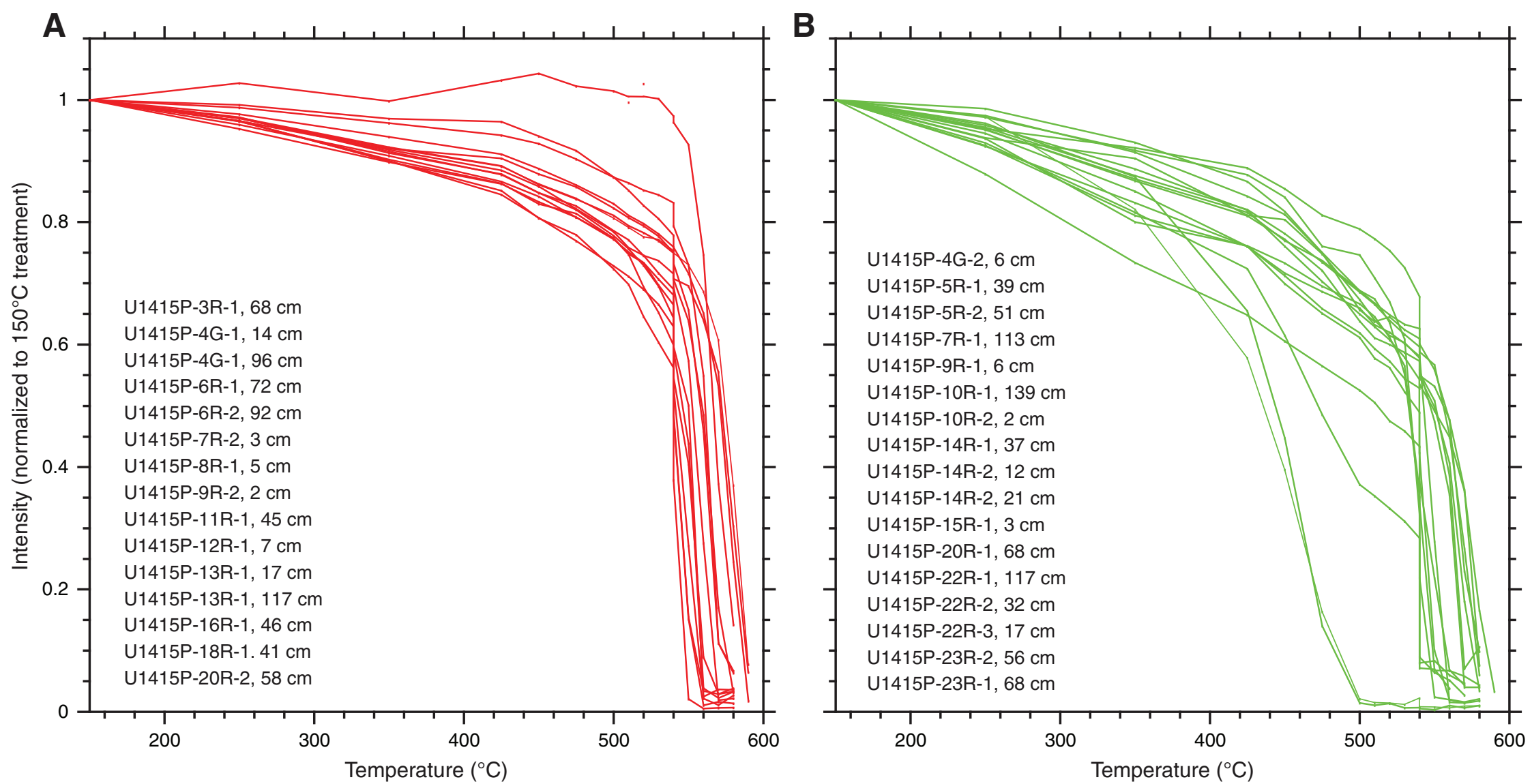
Figure F57. A. Downward-directed linear components picked from alternating field demagnetization data from archive-half core samples measured on the superconducting rock magnetometer. B. High unblocking temperature components from discrete samples cut from working-half core (measured on the JR6A spinner magnetometer). Solid/open symbols = lower/upper hemisphere directions, respectively.

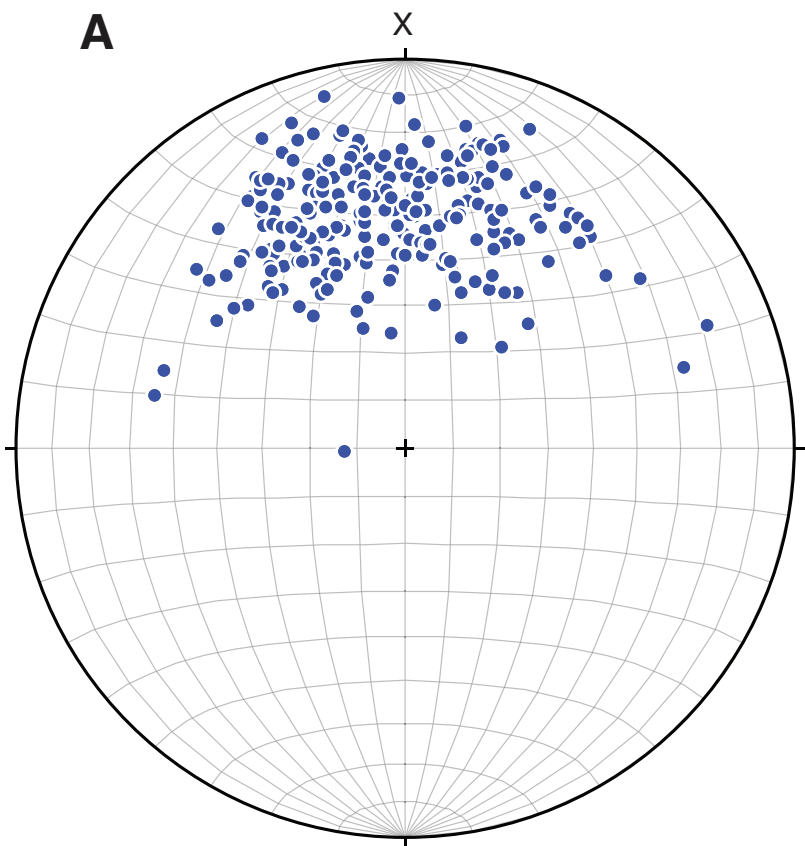

Archive-half core data: Downward linear component

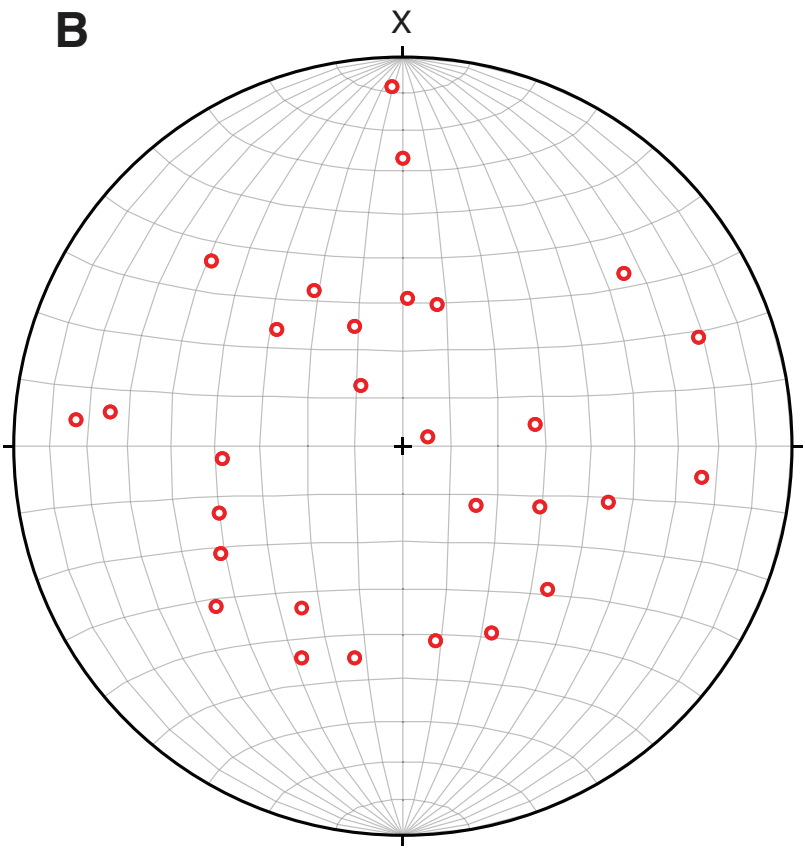

Highest unblocking temperature component in discrete samples 
Figure F58. Inclination variation of high unblocking temperature components in discrete samples, Hole U1415P. Results are consistent with sampling of two blocks with independent rotation histories. See text for details.

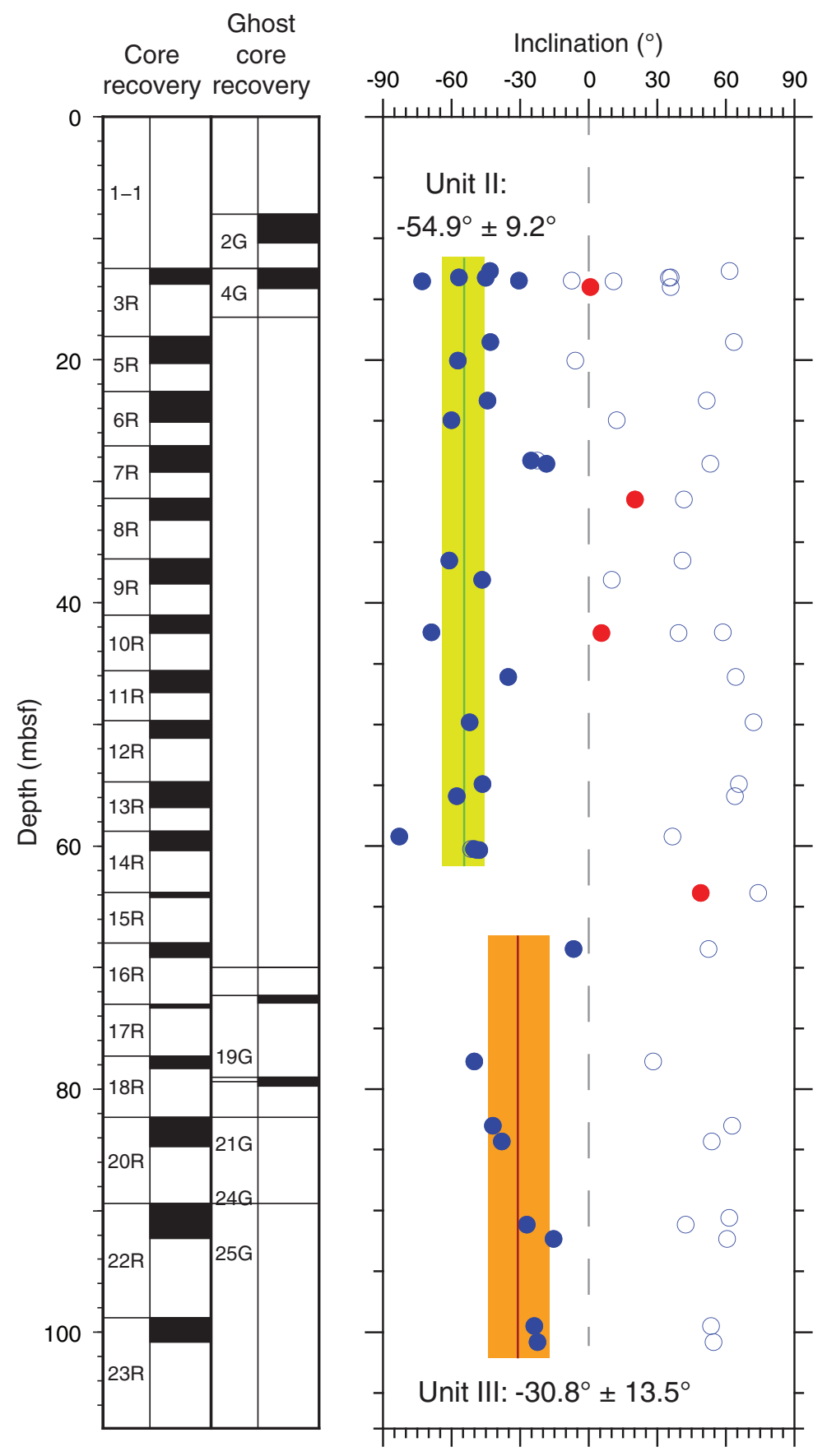


Figure F59. Natural remanent magnetization (NRM) vs. susceptibility of discrete and archive-half core samples, Hole U1415P. The distribution of values compared to lines of constant Q (Königsberger ratio of remanent to induced magnetization; calculated for $25 \mathrm{~A} / \mathrm{m}$ field) shows that remanence is substantially greater than induced magnetization in most samples.

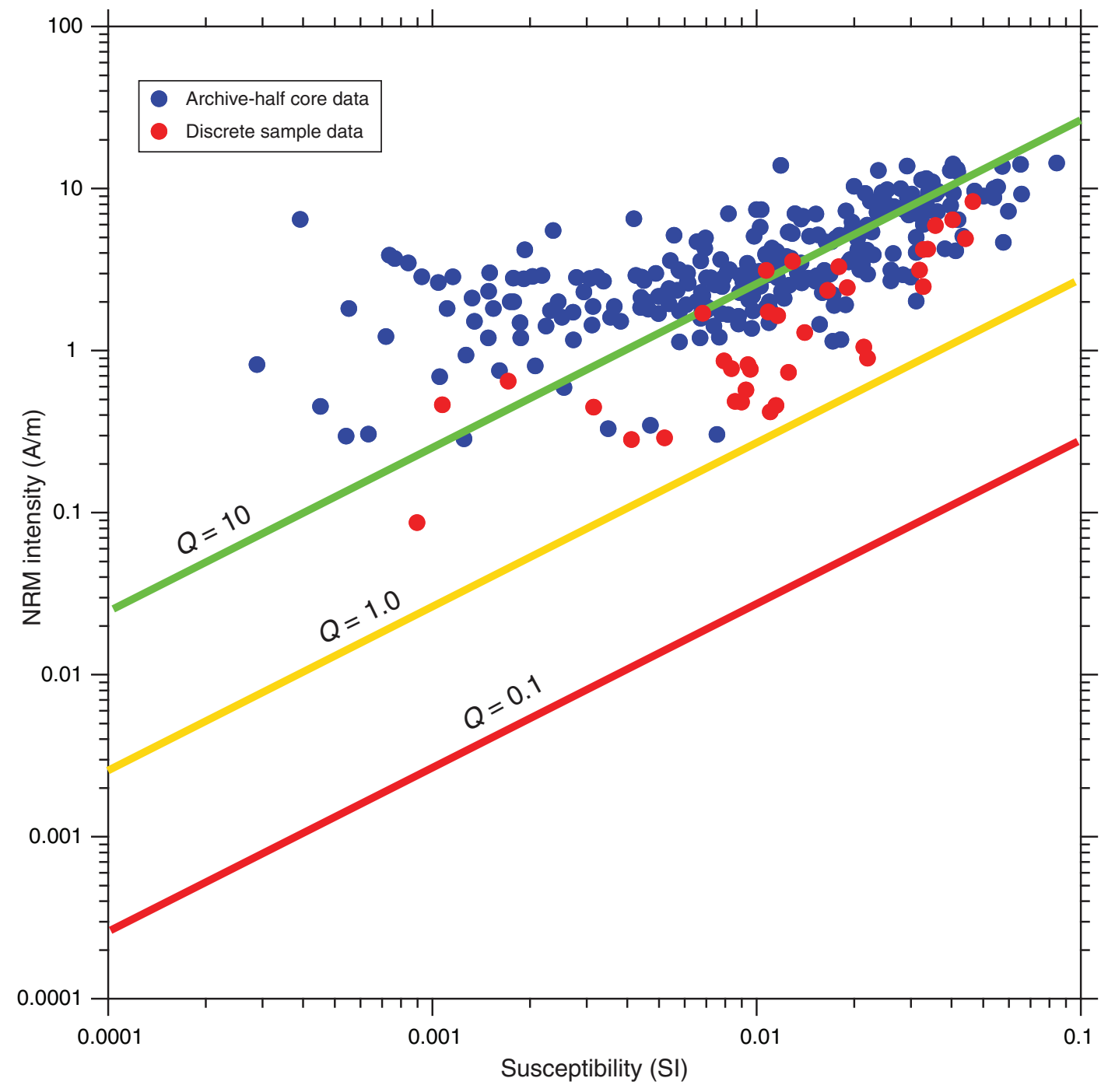


Figure F60. Anisotropy of low-field magnetic susceptibility (AMS) data from 35 discrete samples, Hole U1415P. Bootstrapped mean eigenvectors averaged from three separate measurements of each discrete sample. The $95 \%$ confidence ellipses associated with the maximum, intermediate, and minimum eigenvectors are all $<3.5^{\circ}$. A. Orientation of magnetic fabrics in Unit II are generally consistent with observed magmatic foliations in these core sections. B. A wider range of AMS fabric orientations is evident from samples below $\sim 64$ mbsf. C. Shape factor vs. corrected anisotropy degree shows oblate, triaxial, and prolate AMS ellipsoid shapes are all observed.
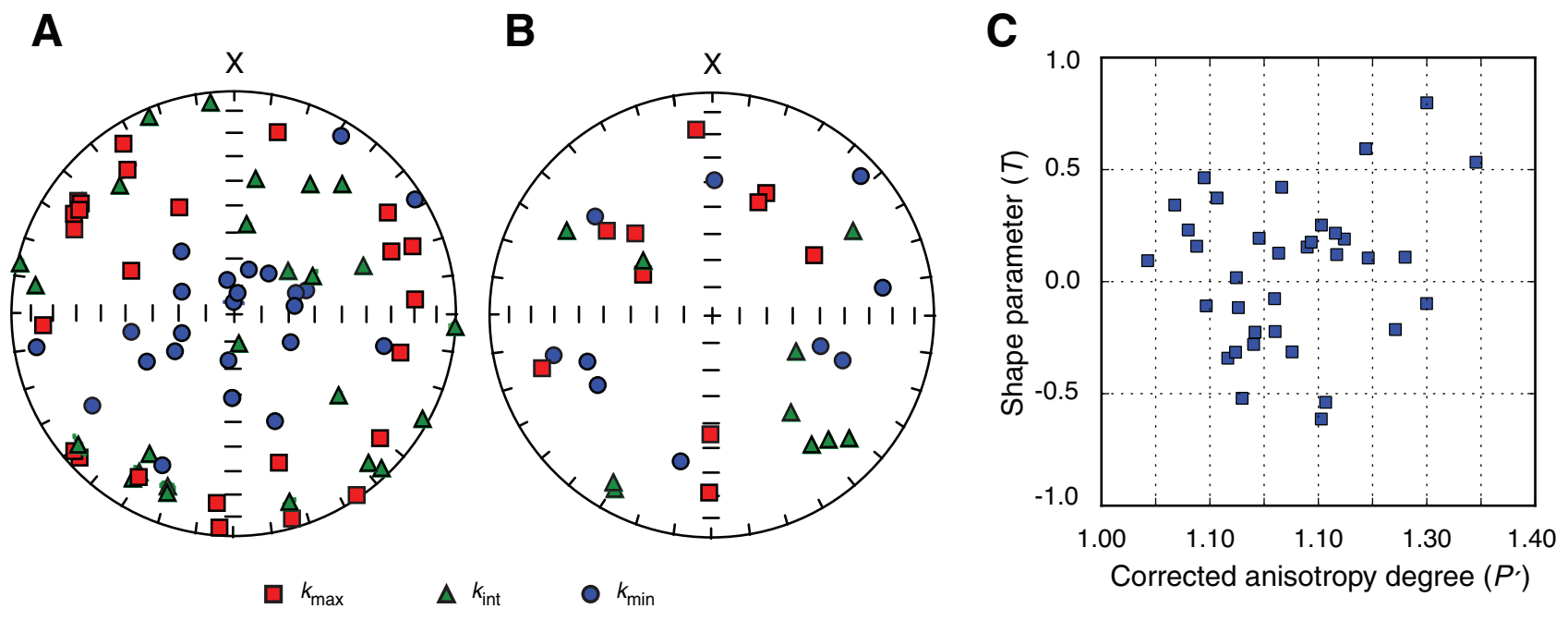
Figure F61. (A) $\mathrm{H}_{2} \mathrm{O}$ and (B) $\mathrm{CO}_{2}$ contents vs. loss on ignition (LOI) for the different rock types recovered in Hole U1415P. For comparison, a compilation of plutonic rock sampled in other holes at Site U1415 is included. Opx = orthopyroxene, $\mathrm{Ol}=$ olivine.

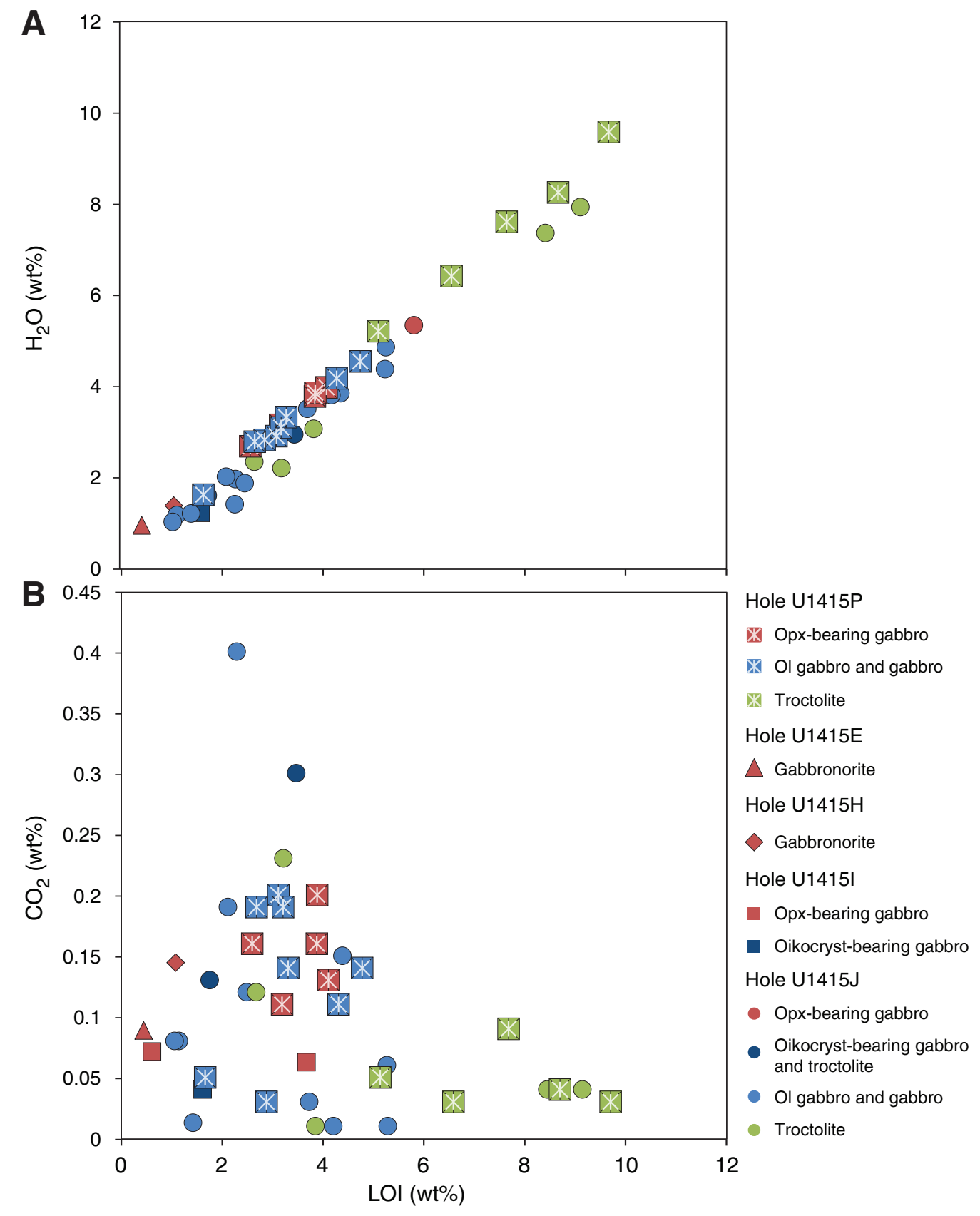


Figure F62. A-F. Selected major and trace compositions for the different rock types recovered in Hole U1415P. For comparison, a compilation of plutonic rock sampled along the East Pacific Rise at Hess Deep, Pito Deep, and other locations (Hékinian et al, 1993; Gillis, Mével, Alan, et al, 1993; Miller et al, 1996; Natland and Dick, 2009; Pedersen et al, 1996; Hanna, 2004; Kirchner and Gillis, 2012; Perk et al, 2007; Saunders et al, 1982) and in other holes at Site U1415 are included. Opx = orthopyroxene, $\mathrm{Ol}=$ olivine.
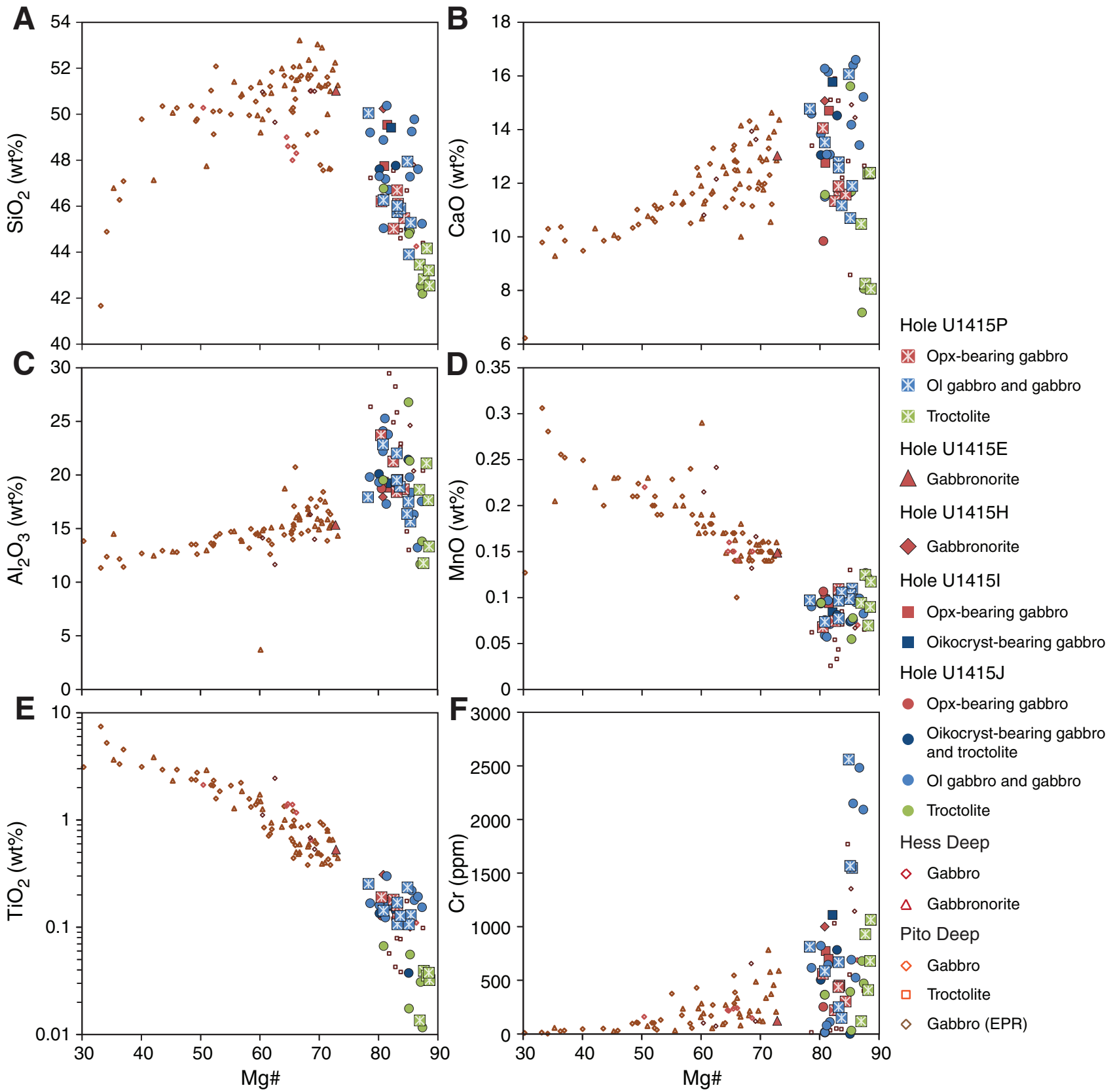
Figure F63. A-D. Trace element compositions of the different rock types recovered in Hole U1415P vs. $\mathrm{TiO}_{2}$. For comparison, a compilation of plutonic rock sampled along the East Pacific Rise at Hess Deep, Pito Deep, and other locations (Hékinian et al, 1993; Gillis, Mével, Alan, et al, 1993; Miller et al, 1996; Natland and Dick, 2009; Pedersen et al, 1996; Hanna, 2004; Kirchner and Gillis, 2012; Perk et al, 2007; Saunders et al, 1982) and in other holes at Site U1415 are included. Opx = orthopyroxene, Ol = olivine.
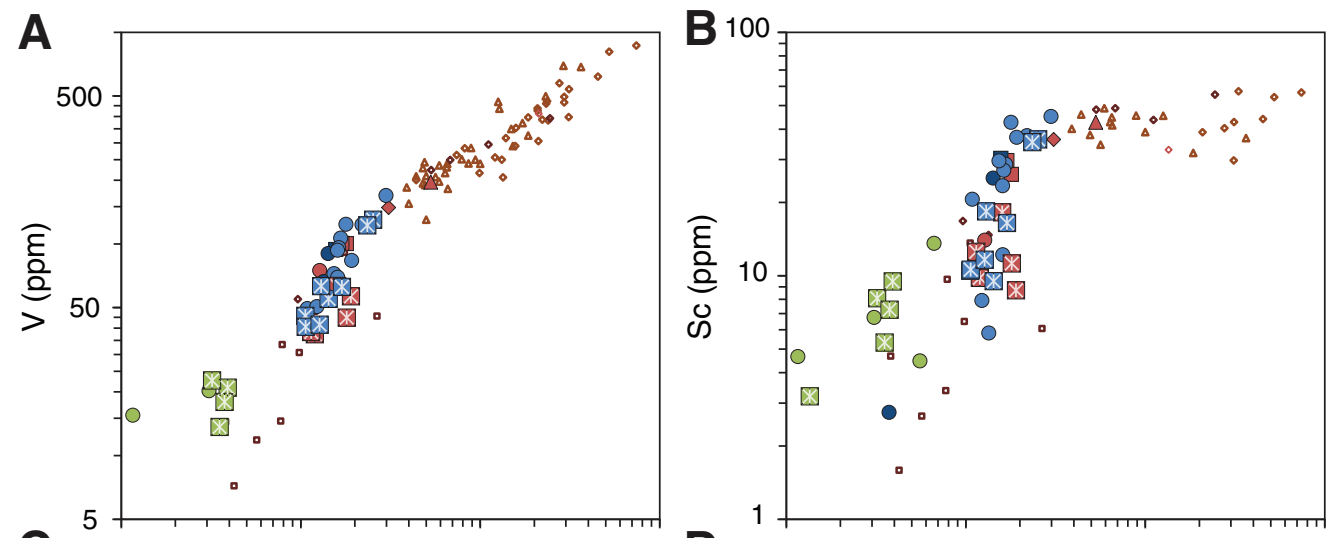

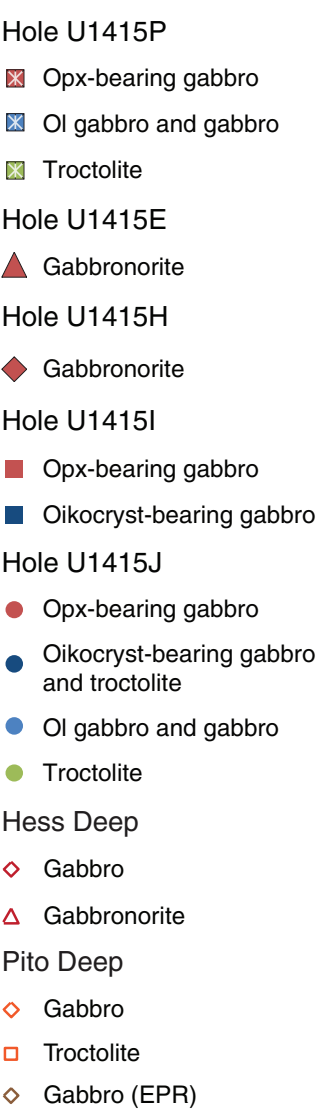


Figure F64. Physical property measurements, Hole U1415P. Plotted gamma ray attenuation (GRA), Whole-Round Multisensor Logger (WRMSL), and Section Half Multisensor Logger (SHMSL) data are filtered (see "Physical properties" in the "Methods" chapter [Gillis et al., 2014f]). WRMSL and SHMSL data from ghost cores are not shown. NGR = natural gamma radiation, MS = magnetic susceptibility.

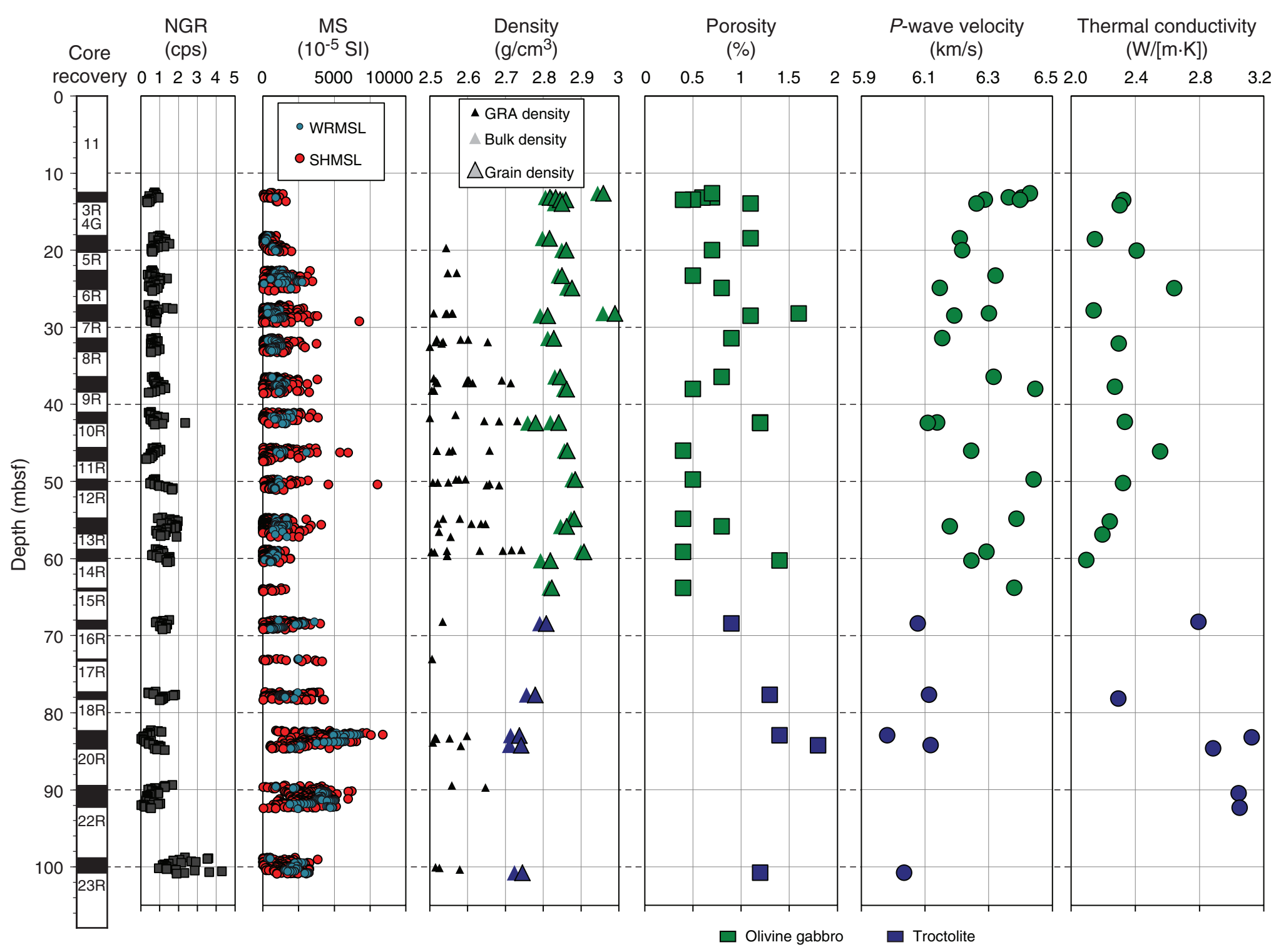


Figure F65. $P$-wave velocity $\left(V_{\mathrm{p}}\right)$ vs. grain density at Site U1415 compared with previous data from gabbroic rock from Hess Deep at Ocean Drilling Program (ODP) Leg 147 Site 894 and from slow-spreading crust in ODP Legs 118 and 176 Hole 735B on the Southwest Indian Ridge, in the Mid-Atlantic Ridge at Kane area, at the MidAtlantic Ridge in the $15^{\circ} \mathrm{N}$ area, and at Integrated Ocean Drilling Program Expedition 304/305 Site U1309 (Atlantis Massif) on the Mid-Atlantic Ridge at $30^{\circ} \mathrm{N}$ (Shipboard Scientific Party, 1989, 1993, 1999, 2004; Cannat, Karson, Miller, et al., 1995; Expedition 304/305 Scientists, 2006). The locations of slow-spreading crust hole, site, or leg numbers on the plot indicate average values.

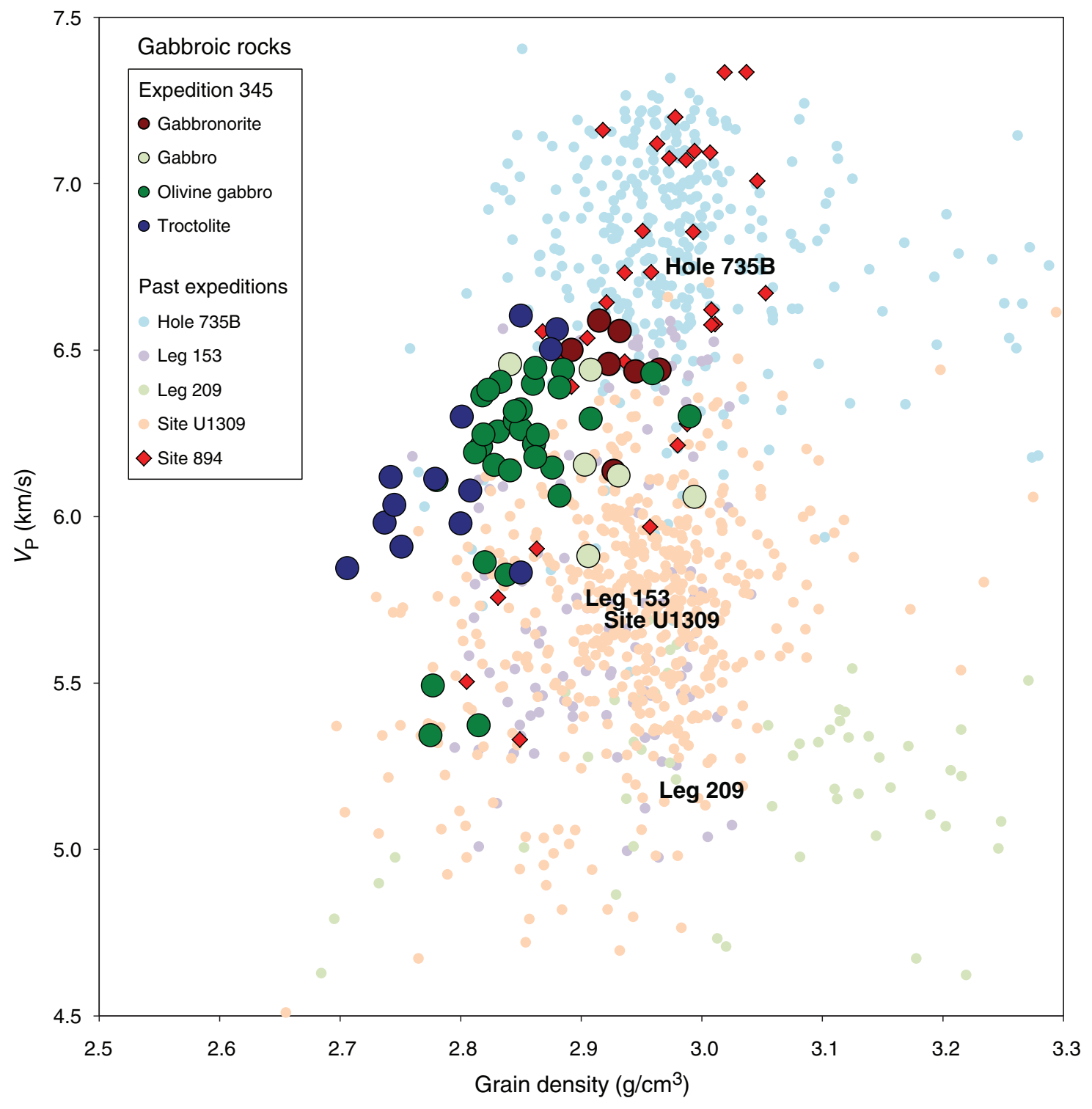


Figure F66. Inverse correlation of grain density with olivine contents (as characterized macroscopically on core section halves), Hole U1415P.

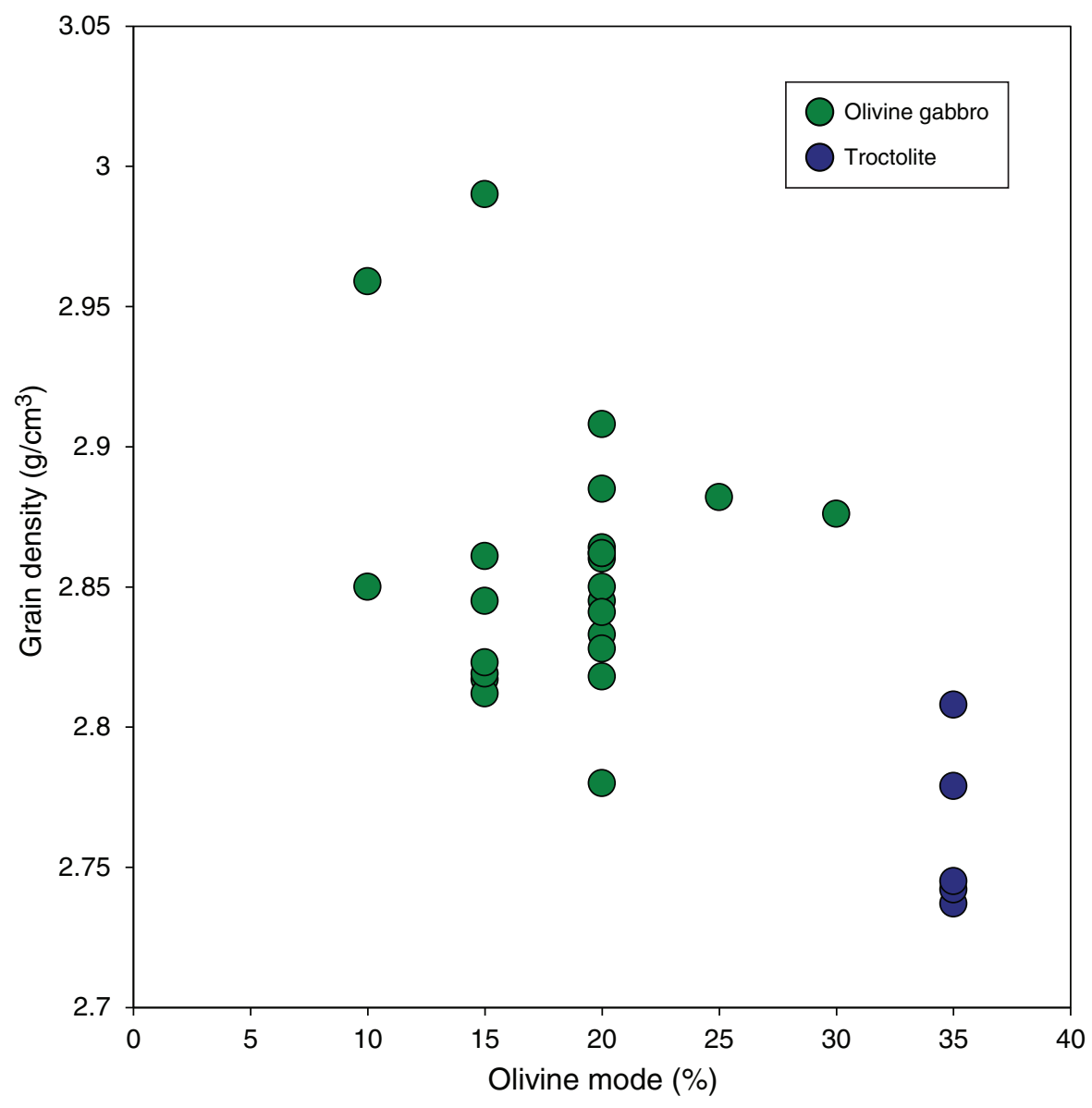


Figure F67. Inverse correlation of $P$-wave velocity $\left(V_{\mathrm{P}}\right)$ with porosity, Hole U1415P.

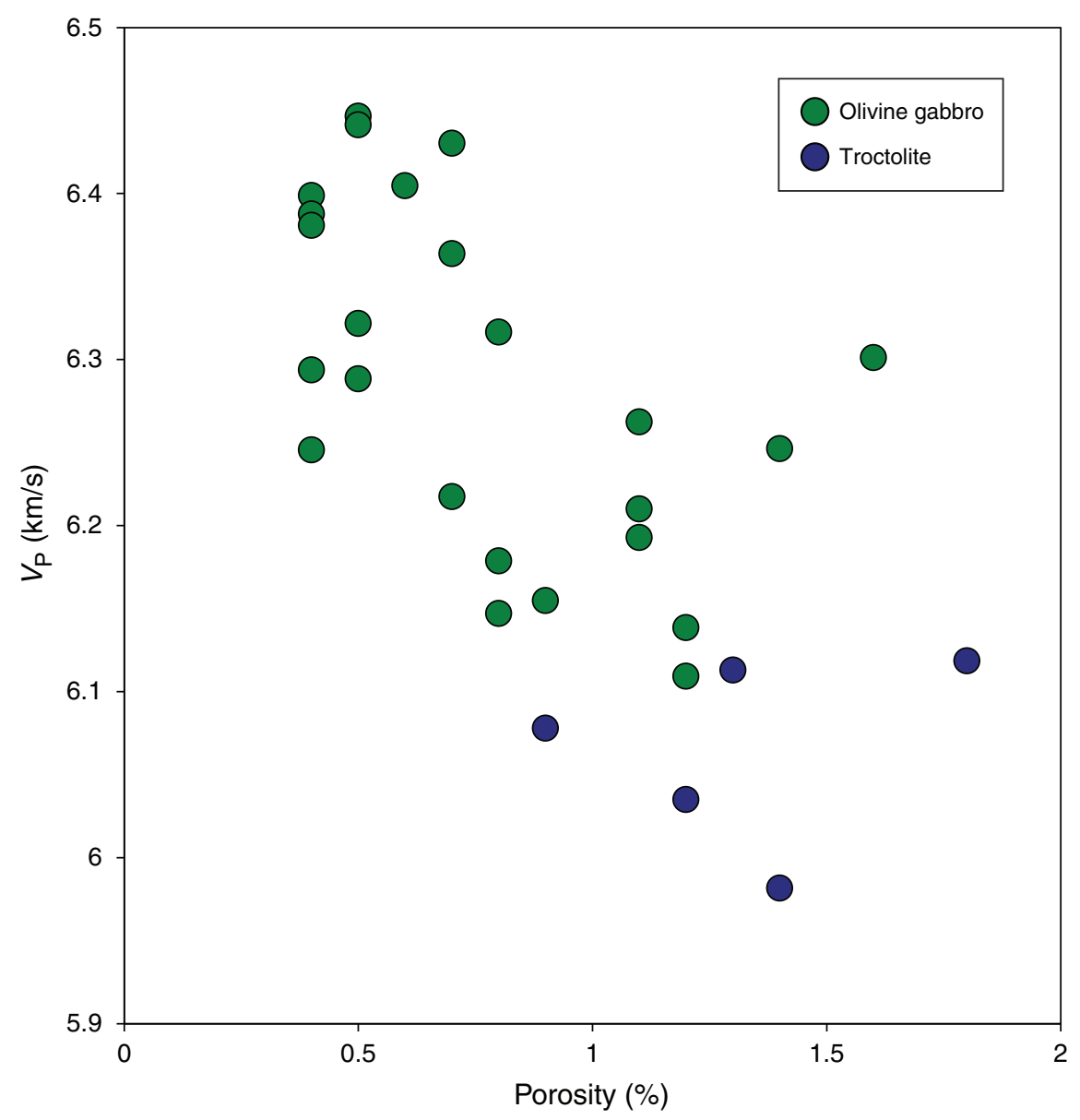


Figure F68. Thermal conductivity measurements on Expedition 345 samples compared with data from previous Ocean Drilling Program (ODP) and Integrated Ocean Drilling Program (IODP) gabbroic cores. Curves are compiled data from fast- and slow-spreading crust at Hess Deep ODP Leg 147 Site 894, ODP Hole 1256D, ODP Legs 118 and 176 Hole 735B at the Southwest Indian Ridge, the Mid-Atlantic Ridge at Kane area, the Mid-Atlantic Ridge in the $15^{\circ} \mathrm{N}$ area, and IODP Expedition 304/305 Site U1309 (Atlantis Massif) on the Mid-Atlantic Ridge at $30^{\circ} \mathrm{N}$ (Shipboard Scientific Party, 1989, 1993, 1999, 2004; Cannat, Karson, Miller, et al., 1995; Expedition 304/305 Scientists, 2006; Expedition 309/312 Scientists, 2006). Large circles and horizontal bars show the average and range of thermal conductivity values, respectively.

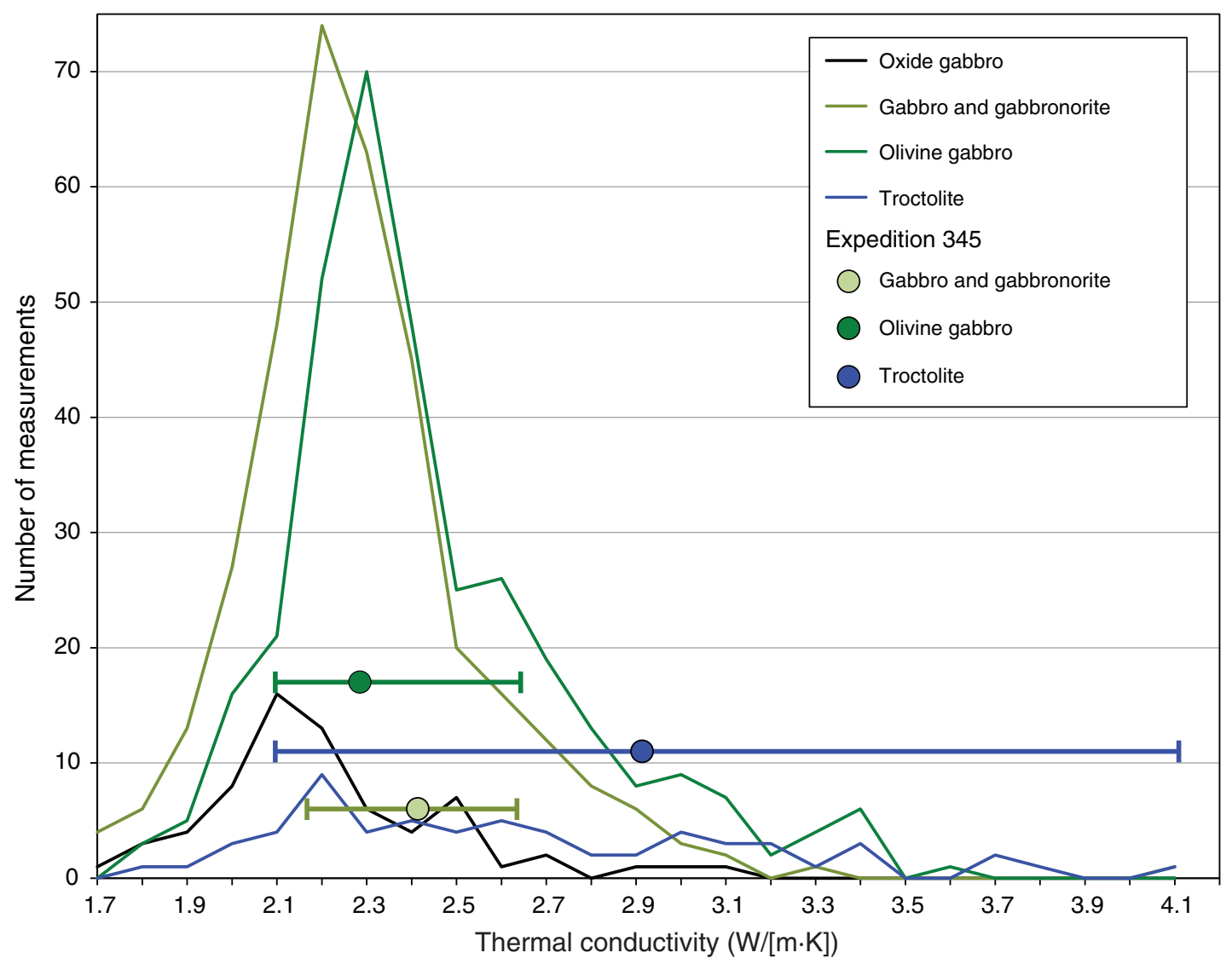


Table T1. Operations summary, Hole U1415P.

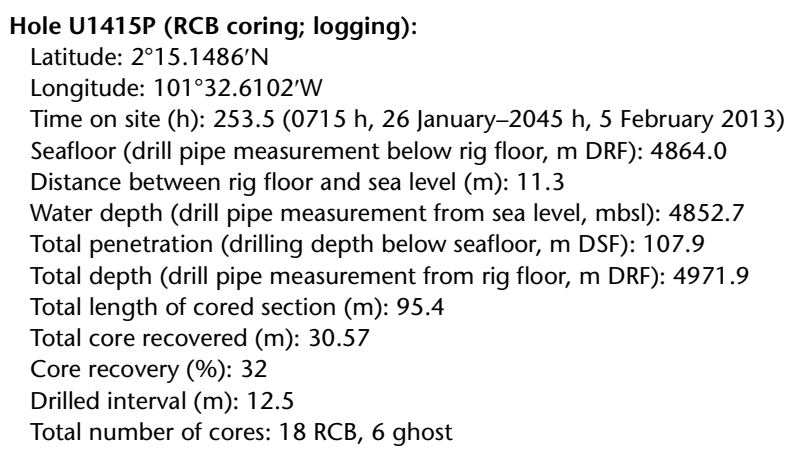

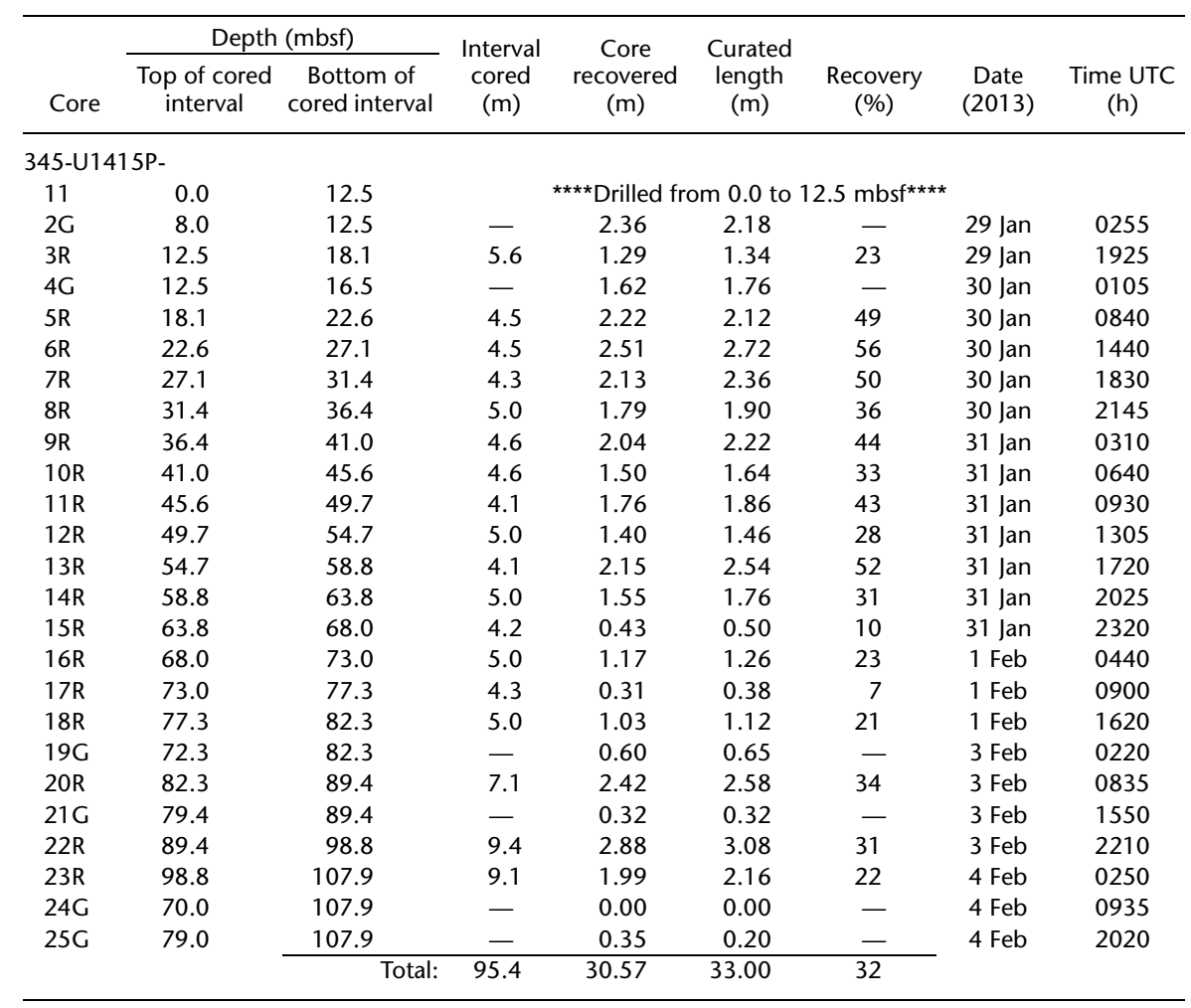

Local ship time was UTC $-7 \mathrm{~h}$. Ghost core $(\mathrm{G})$ is not included in totals. DRF = drilling depth below rig floor, DSF = drilling depth below seafloor. $\mathrm{R}=$ rotary core barrel $(\mathrm{RCB})$ system, numeric core type $=$ drilled interval. $-=$ not calculated. 
Table T2. Summary of lithologic intervals and their classification into units, Hole U1415P. (Continued on next three pages.)

\begin{tabular}{|c|c|c|c|c|c|c|c|c|c|c|c|}
\hline \multirow[b]{2}{*}{ Unit } & \multirow[b]{2}{*}{ Description } & \multirow{2}{*}{$\begin{array}{l}\text { Core, section, } \\
\text { interval }(\mathrm{cm})\end{array}$} & \multicolumn{2}{|c|}{ Depth (mbsf) } & \multirow[b]{2}{*}{ Pieces } & \multirow{2}{*}{$\begin{array}{l}\text { Lithologic } \\
\text { interval }\end{array}$} & \multirow[b]{2}{*}{ Contact type } & \multirow{2}{*}{$\begin{array}{c}\text { Contact } \\
\text { definition }\end{array}$} & \multirow[b]{2}{*}{ Complete lithology name } & \multirow[b]{2}{*}{ Modal grain size } & \multirow[b]{2}{*}{ Texture } \\
\hline & & & Top & Bottom & & & & & & & \\
\hline \multirow{9}{*}{ I } & & 345-U1415P- & & & & & & & & & \\
\hline & Surficial sand & $2 \mathrm{G}-1 \mathrm{~A}, 0-15$ & 8.0 & 8.2 & & G1 & Not recovered & & Silty sand & Very fine & \\
\hline & and rubble & $2 \mathrm{G}-1 \mathrm{~A}, 15-150$ & 8.2 & 9.5 & & G2 & Color & & Silty sand & Very fine & \\
\hline & & $2 \mathrm{G}-2 \mathrm{~A}, 0-31$ & 9.5 & 9.8 & 1 & G3 & Not recovered & & Sand & Very fine & \\
\hline & & $2 G-2 A, 31-36$ & 9.8 & 9.9 & 2 & G4 & Not recovered & & Gabbroic sand & Fine to coarse & \\
\hline & & $2 \mathrm{G}-2 \mathrm{~A}, 36-52$ & 9.9 & 10.0 & 3 & G5 & Not recovered & & Gabbroic rubble & Cobbles & \\
\hline & & $2 \mathrm{G}-2 \mathrm{~A}, 52-58$ & 10.0 & 10.1 & 4 & G6 & Not recovered & & Olivine gabbro & Medium grained & Poikilitic-granular \\
\hline & & $2 \mathrm{G}-2 \mathrm{~A}, 58-61$ & 10.1 & 10.1 & 5 & G7 & Not recovered & & $\begin{array}{l}\text { Orthopyroxene-bearing } \\
\text { olivine gabbro }\end{array}$ & Coarse grained & Poikilitic-granular \\
\hline & & 2G-2A, 61-68 & 10.1 & 10.2 & 6 & G8 & Not recovered & & Sparsely phyric basalt & Less than fine grained & Aphanitic \\
\hline \multirow[t]{24}{*}{ II } & $\begin{array}{l}\text { Multitextured } \\
\text { Layered }\end{array}$ & $3 R-1 A, 0-30$ & 12.5 & 12.8 & $\begin{array}{c}1,2,3,4,5 \\
6\end{array}$ & 1 & Not recovered & & Olivine gabbro & $\begin{array}{l}\text { Medium to coarse } \\
\text { grained }\end{array}$ & Granular \\
\hline & Gabbro & $3 R-1 A, 30-34$ & 12.8 & 12.8 & 7 & 2 & Not recovered & & Olivine gabbro & Medium grained & Poikilitic-granular \\
\hline & Series & 3R-1A, 34-133.5 & 12.8 & 13.8 & $\begin{array}{r}8,9,10,11 \\
12,13,14 \\
15,16,17 \\
18,19,20 \\
21,22\end{array}$ & 3 & Not recovered & & Olivine gabbro & Coarse grained & Granular \\
\hline & & $4 G-1 A, 0-3$ & 12.5 & 12.5 & 1 & G9 & Not recovered & & Olivine-bearing gabbro & Coarse grained & Poikilitic-granular \\
\hline & & $4 G-1 A, 3-8$ & 12.5 & 12.6 & 2 & G10 & Not recovered & & Olivine-bearing gabbro & Coarse grained & Poikilitic-granular \\
\hline & & 4G-1A, 8-18 & 12.6 & 12.7 & 3 & G11 & Not recovered & & $\begin{array}{l}\text { Orthopyroxene-bearing } \\
\text { olivine gabbro }\end{array}$ & Medium grained & Granular \\
\hline & & 4G-1A, 18-29 & 12.7 & 12.8 & 4 & G12 & Not recovered & & Olivine gabbro & Coarse grained & Granular \\
\hline & & 4G-1A, 29-37 & 12.8 & 12.9 & 5 & G13 & Not recovered & & Olivine gabbro & Coarse grained & Granular \\
\hline & & 4G-1A, 37-50 & 12.9 & 13.0 & 6 & G14 & Not recovered & & Olivine gabbro & Coarse grained & Granular \\
\hline & & 4G-1A, 50-62 & 13.0 & 13.1 & 7 & G15 & Not recovered & & $\begin{array}{l}\text { Orthopyroxene-bearing } \\
\text { olivine gabbro }\end{array}$ & Coarse grained & Poikilitic-granular \\
\hline & & 4G-1A, 62-93 & 13.1 & 13.4 & 8 & G16 & Not recovered & & Olivine gabbro & Pegmatitic & Poikilitic-granular \\
\hline & & 4G-1A, 93-110 & 13.4 & 13.6 & 9 & G17 & Not recovered & & Olivine gabbro & Coarse grained & Poikilitic-granular \\
\hline & & 4G-1A, 110-126 & 13.6 & 13.8 & 10 & G18 & Not recovered & & Olivine gabbro & Coarse grained & Poikilitic-granular \\
\hline & & 4G-1A, 126-141 & 13.8 & 13.9 & 11 & G19 & Not recovered & & Olivine gabbro & Coarse grained & Poikilitic-granular \\
\hline & & 4G-2A, 0-21 & 13.9 & 14.1 & 1 & G20 & Not recovered & & Olivine gabbro & Coarse grained & Granular \\
\hline & & $4 G-2 A, 21-24$ & 14.1 & 14.2 & 2 & G21 & Not recovered & & Olivine gabbro & Coarse grained & Granular \\
\hline & & $4 G-2 A, 24-35$ & 14.2 & 14.3 & 3 & G22 & Not recovered & & Olivine gabbro & Coarse grained & Granular \\
\hline & & 5R-1A, 0-142 & 18.1 & 19.5 & $\begin{array}{c}1,2,3,4,5 \\
6,7,8,9 \\
310,11 \\
12,13,14\end{array}$ & 3 & Not recovered & & $\begin{array}{l}\text { Orthopyroxene-bearing } \\
\text { olivine gabbro }\end{array}$ & Coarse grained & Granular \\
\hline & & 5R-2A, 0-70.5 & 19.5 & 20.2 & $\begin{array}{l}1,2,3,4,5 \\
6,7\end{array}$ & 3 & Not recovered & & $\begin{array}{l}\text { Orthopyroxene-bearing } \\
\text { olivine gabbro }\end{array}$ & Coarse grained & Granular \\
\hline & & $6 \mathrm{R}-1 \mathrm{~A}, 0-26$ & 22.6 & 22.9 & $1,2,3$ & 3 & Not recovered & & $\begin{array}{l}\text { Orthopyroxene-bearing } \\
\text { olivine gabbro }\end{array}$ & Coarse grained & Granular \\
\hline & & 6R-1A, 26-70 & 22.9 & 23.3 & $4,5,6,7$ & 4 & Not recovered & & Olivine gabbro & Medium grained & Granular \\
\hline & & 6R-1A, 70-140.5 & 23.3 & 24.0 & $7,8,9,10$ & 5 & Modal and textural & $\begin{array}{l}\text { Sharp to } \\
\text { gradational }\end{array}$ & Olivine gabbro & Coarse grained & Multitextured \\
\hline & & $6 \mathrm{R}-2 \mathrm{~A}, 0-30$ & 24.0 & 24.3 & $1,2,3$ & 6 & Not recovered & & Olivine gabbro & Coarse grained & Poikilitic to granular \\
\hline & & $6 \mathrm{R}-2 \mathrm{~A}, 30-58$ & 24.3 & 24.6 & $3,4,5,6$ & 7 & Modal and textural & $\begin{array}{l}\text { Sharp to } \\
\text { gradational }\end{array}$ & Olivine gabbro & Coarse grained & Multitextured \\
\hline
\end{tabular}


Table T2 (continued). (Continued on next page.)

\begin{tabular}{|c|c|c|c|c|c|c|c|c|c|c|c|}
\hline \multirow[b]{2}{*}{ Unit } & \multirow[b]{2}{*}{ Description } & \multirow{2}{*}{$\begin{array}{l}\text { Core, section, } \\
\text { interval }(\mathrm{cm})\end{array}$} & \multicolumn{2}{|c|}{ Depth (mbsf) } & \multirow[b]{2}{*}{ Pieces } & \multirow{2}{*}{$\begin{array}{l}\text { Lithologic } \\
\text { interval }\end{array}$} & \multirow[b]{2}{*}{ Contact type } & \multirow{2}{*}{$\begin{array}{l}\text { Contact } \\
\text { definition }\end{array}$} & \multirow[b]{2}{*}{ Complete lithology name } & \multirow[b]{2}{*}{ Modal grain size } & \multirow[b]{2}{*}{ Texture } \\
\hline & & & Top & Bottom & & & & & & & \\
\hline & & $6 \mathrm{R}-2 \mathrm{~A}, 58-118$ & 24.6 & 25.2 & $\begin{array}{r}6,7,8,9,10 \\
11,12,13\end{array}$ & 8 & Modal and textural & $\begin{array}{l}\text { Sharp to } \\
\text { gradational }\end{array}$ & Troctolitic olivine gabbro & Medium grained & Multitextured \\
\hline & & $6 \mathrm{R}-2 \mathrm{~A}, 118-122$ & 25.2 & 25.2 & 14 & 9 & Not recovered & & $\begin{array}{l}\text { Orthopyroxene bearing } \\
\text { olivine gabbro }\end{array}$ & Coarse grained & Multitextured \\
\hline & & $6 \mathrm{R}-2 \mathrm{~A}, 122-131.5$ & 25.2 & 25.3 & 15 & 10 & Not recovered & & Olivine gabbro & Coarse grained & Multitextured \\
\hline & & 7R-1A, 0-14 & 27.1 & 27.2 & 1,2 & 11 & Not recovered & & Olivine gabbro & Coarse grained & Granular \\
\hline & & $7 R-1 A, 14-41$ & 27.2 & 27.5 & $2,3,4,5,6$ & 12 & Not recovered & & $\begin{array}{l}\text { Orthopyroxene bearing } \\
\text { olivine gabbro }\end{array}$ & Medium grained & Granular \\
\hline & & 7R-1A, 41-139 & 27.5 & 28.5 & $\begin{array}{l}7,8,9,10 \\
11,12,13\end{array}$ & 13 & Not recovered & & $\begin{array}{l}\text { Orthopyroxene bearing } \\
\text { olivine gabbro }\end{array}$ & Coarse to pegmatitic & Multitextured \\
\hline & & $7 R-2 A, 0-56$ & 28.5 & 29.1 & 1,2 & 13 & Not recovered & & $\begin{array}{l}\text { Orthopyroxene bearing } \\
\text { olivine gabbro }\end{array}$ & Pegmatitic & Multitextured \\
\hline & & $7 R-2 A, 56-70$ & 29.1 & 29.2 & 3,4 & 14 & Not recovered & & $\begin{array}{l}\text { Orthopyroxene bearing } \\
\text { olivine gabbro }\end{array}$ & Coarse grained & Granular \\
\hline & & 7R-2A, 70-96.5 & 29.2 & 29.5 & $5,6,7,8$ & 15 & Not recovered & & $\begin{array}{l}\text { Orthopyroxene bearing } \\
\text { olivine gabbro }\end{array}$ & Pegmatitic & Multitextured \\
\hline & & $8 R-1 A, 0-29$ & 31.4 & 31.7 & 1,2 & 16 & Not recovered & & Olivine gabbro & Coarse grained & Granular \\
\hline & & 8R-1A, 29-146 & 31.7 & 32.9 & $\begin{array}{l}2,3,4,5,6 \\
7,8,9\end{array}$ & 17 & Modal and textural & $\begin{array}{l}\text { Sharp to } \\
\text { gradational }\end{array}$ & $\begin{array}{l}\text { Orthopyroxene bearing } \\
\text { olivine gabbro }\end{array}$ & Coarse grained & Multitextured \\
\hline & & $8 R-2 A, 0-44.5$ & 32.9 & 33.3 & $1,2,3$ & 17 & Not recovered & & $\begin{array}{l}\text { Orthopyroxene bearing } \\
\text { olivine gabbro }\end{array}$ & Coarse grained & Multitextured \\
\hline & & 9R-1A, 0-18 & 36.4 & 36.6 & 1 & 18 & Not recovered & & Olivine gabbro & Medium grained & Granular \\
\hline & & $9 \mathrm{R}-1 \mathrm{~A}, 18-141.5$ & 36.6 & 37.8 & $\begin{array}{r}2,3,4,5,6 \\
7,8,9,10\end{array}$ & 19 & Not recovered & & $\begin{array}{l}\text { Orthopyroxene bearing } \\
\text { olivine gabbro }\end{array}$ & Coarse to pegmatitic & Multitextured \\
\hline & & $9 \mathrm{R}-2 \mathrm{~A}, 0-12$ & 37.8 & 37.9 & 1,2 & 20 & Not recovered & & $\begin{array}{l}\text { Orthopyroxene bearing } \\
\text { olivine gabbro }\end{array}$ & Coarse grained & Multitextured \\
\hline & & $9 \mathrm{R}-2 \mathrm{~A}, 12-70$ & 37.9 & 38.5 & $3,4,5,6,7$ & 21 & Not recovered & & $\begin{array}{l}\text { Orthopyroxene bearing } \\
\text { olivine gabbro }\end{array}$ & Medium grained & Multitextured \\
\hline & & $9 \mathrm{R}-2 \mathrm{~A}, 70-80$ & 38.5 & 38.6 & 8 & 22 & Not recovered & & $\begin{array}{l}\text { Olivine bearing Olivine } \\
\text { gabbro }\end{array}$ & Medium grained & Granular \\
\hline & & 10R-1A, 0-55 & 41.0 & 41.6 & $\begin{array}{l}1,2,3,4,5 \\
6\end{array}$ & 23 & Not recovered & & Olivine gabbro & Medium grained & Granular \\
\hline & & 10R-1A, 55-93 & 41.6 & 41.9 & $7,8,9,10$ & 24 & Not recovered & & Olivine gabbro & Pegmatitic & Multitextured \\
\hline & & 10R-1A, 93-143 & 41.9 & 42.4 & $\begin{array}{c}10,11,12 \\
13,14\end{array}$ & 25 & Modal and textural & $\begin{array}{l}\text { Sharp to } \\
\text { gradational }\end{array}$ & $\begin{array}{l}\text { Orthopyroxene bearing } \\
\text { olivine gabbro }\end{array}$ & Coarse grained & Multitextured \\
\hline & & $10 \mathrm{R}-2 \mathrm{~A}, 0-21$ & 42.4 & 42.6 & 1,2 & 25 & Not recovered & & $\begin{array}{l}\text { Orthopyroxene bearing } \\
\text { olivine gabbro }\end{array}$ & Coarse grained & Multitextured \\
\hline & & 11R-1A, 0-149 & 45.6 & 47.1 & $\begin{array}{c}1,2,3,4,5 \\
6,7,8,9 \\
10,11,12 \\
13,14,15 \\
16,17,18\end{array}$ & 25 & Not recovered & & $\begin{array}{l}\text { Orthopyroxene bearing } \\
\text { olivine gabbro }\end{array}$ & Coarse grained & Multitextured \\
\hline & & $11 \mathrm{R}-2 \mathrm{~A}, 0-36.5$ & 47.1 & 47.5 & $1,2,3,4,5$ & 25 & Not recovered & & $\begin{array}{l}\text { Orthopyroxene bearing } \\
\text { olivine gabbro }\end{array}$ & Coarse grained & Multitextured \\
\hline & & $12 \mathrm{R}-1 \mathrm{~A}, 0-145.5$ & 49.7 & 51.2 & $\begin{array}{c}1,2,3,4,5 \\
6,7,8,9 \\
10,11,12 \\
13,14,15\end{array}$ & 25 & Not recovered & & $\begin{array}{l}\text { Orthopyroxene bearing } \\
\text { olivine gabbro }\end{array}$ & Coarse grained & Multitextured \\
\hline & & 13R-1A, 0-21 & 54.7 & 54.9 & 1,2 & 26 & Not recovered & & Olivine gabbro & Medium grained & Granular \\
\hline & & $13 R-1 A, 21-140.5$ & 54.9 & 56.1 & $\begin{array}{c}3,4,5,6,7 \\
8,9,10 \\
11,12\end{array}$ & 27 & Not recovered & & Olivine gabbro & Coarse grained & Multitextured \\
\hline
\end{tabular}


Table T2 (continued). (Continued on next page.)

\begin{tabular}{|c|c|c|c|c|c|c|c|c|c|c|c|}
\hline \multirow[b]{2}{*}{ Unit } & \multirow[b]{2}{*}{ Description } & \multirow{2}{*}{$\begin{array}{l}\text { Core, section, } \\
\text { interval }(\mathrm{cm})\end{array}$} & \multicolumn{2}{|c|}{ Depth (mbsf) } & \multirow[b]{2}{*}{ Pieces } & \multirow{2}{*}{$\begin{array}{l}\text { Lithologic } \\
\text { interval }\end{array}$} & \multirow[b]{2}{*}{ Contact type } & \multirow{2}{*}{$\begin{array}{l}\text { Contact } \\
\text { definition }\end{array}$} & \multirow[b]{2}{*}{ Complete lithology name } & \multirow[b]{2}{*}{ Modal grain size } & \multirow[b]{2}{*}{ Texture } \\
\hline & & & Top & Bottom & & & & & & & \\
\hline & & 13R-2A, 0-113 & 56.1 & 57.2 & $\begin{array}{c}1,2,3,4,5 \\
6,7,8,9 \\
10,11,12\end{array}$ & 27 & Not recovered & & Olivine gabbro & Coarse grained & Multitextured \\
\hline & & 14R-1A, 0-93 & 58.8 & 59.7 & $\begin{array}{l}1,2,3,4,5 \\
6,7,8\end{array}$ & 27 & Not recovered & & Olivine gabbro & Coarse grained & Multitextured \\
\hline & & 14R-1A, 93-129 & 59.7 & 60.1 & $9,10,11,12$ & 28 & Not recovered & & Olivine gabbro & Coarse grained & Multitextured \\
\hline & & 14R-2A, 0-47 & 60.1 & 60.6 & 1,2 & 28 & Not recovered & & Olivine gabbro & Coarse grained & Multitextured \\
\hline & & 15R-1A, 0-39 & 63.8 & 64.2 & $\begin{array}{l}1,2,3,4,5 \\
6\end{array}$ & 28 & Not recovered & & Olivine gabbro & Coarse grained & Multitextured \\
\hline \multirow[t]{22}{*}{ III } & $\begin{array}{l}\text { Troctolite } \\
\text { Series }\end{array}$ & 15R-1A, 39-50 & 64.2 & 64.3 & $7,8,9$ & 29 & Not recovered & & Troctolite & Medium grained & Granular \\
\hline & & 16R-1A，0-126.5 & 68.0 & 69.3 & $\begin{array}{c}1,2,3,4,5 \\
6,7,8,9 \\
10,11\end{array}$ & 29 & Not recovered & & Troctolite & Medium grained & Granular \\
\hline & & 17R-1A, 0-38.5 & 73.0 & 73.4 & $1,2,3,4,5$ & 29 & Not recovered & & Troctolite & Medium grained & Granular \\
\hline & & $18 \mathrm{R}-1 \mathrm{~A}, 0-112$ & 77.3 & 78.4 & $\begin{array}{c}1,2,3,4,5 \\
6,7,8,9 \\
10\end{array}$ & 29 & Not recovered & & Troctolite & Medium grained & Granular \\
\hline & & $19 \mathrm{G}-1 \mathrm{~A}, 0-8$ & 72.3 & 72.4 & 1 & G23 & Not recovered & & Olivine gabbro & Medium grained & Granular \\
\hline & & 19G-1A, 8-12 & 72.4 & 72.4 & 2 & G24 & Not recovered & & Olivine gabbro & Coarse grained & Multitextured \\
\hline & & 19G-1A, 12-23 & 72.4 & 72.5 & 3 & $\mathrm{G} 25$ & Not recovered & & $\begin{array}{l}\text { Orthopyroxene-bearing } \\
\text { olivine gabbro }\end{array}$ & $\begin{array}{l}\text { Medium to coarse } \\
\text { grained }\end{array}$ & Granular \\
\hline & & 19G-1A, 23-32 & 72.5 & 72.6 & 4 & G26 & Not recovered & & Troctolitic olivine gabbro & $\begin{array}{l}\text { Medium to coarse } \\
\text { grained }\end{array}$ & Granular \\
\hline & & 19G-1A, 32-37 & 72.6 & 72.7 & 5 & G27 & Not recovered & & Olivine gabbro & Pegmatitic & Multitextured \\
\hline & & 19G-1A, 37-41 & 72.7 & 72.7 & 6 & G28 & Not recovered & & Troctolite rubble & & \\
\hline & & 19G-1A, 41-49 & 72.7 & 72.8 & 7 & G29 & Not recovered & & Troctolite & Coarse grained & Granular \\
\hline & & 19G-1A, 49-58 & 72.8 & 72.9 & 8 & G30 & Not recovered & & Troctolite & $\begin{array}{l}\text { Medium to coarse } \\
\text { grained }\end{array}$ & Granular \\
\hline & & 19G-1A, 58-61 & 72.9 & 72.9 & 9 & G31 & Not recovered & & Troctolite & Medium grained & Granular \\
\hline & & 19G-1A, 61-65 & 72.9 & 73.0 & 10 & G32 & Not recovered & & Troctolite & Medium grained & Granular \\
\hline & & 20R-1A, 0-138 & 82.3 & 83.7 & $\begin{array}{c}1,2,3,4,5 \\
6,7,8,9 \\
10,11,12 \\
13,14\end{array}$ & 29 & Not recovered & & Troctolite & Medium grained & Granular \\
\hline & & 20R-2A, $0-120.5$ & 83.7 & 84.9 & $\begin{array}{c}1,2,3,4,5 \\
6,7,8,9 \\
10,11\end{array}$ & 29 & Not recovered & & Troctolite & Medium grained & Granular \\
\hline & & $21 \mathrm{G}-1 \mathrm{~A}, 0-3$ & 79.4 & 79.4 & 1 & G33 & Not recovered & & Troctolite & $\begin{array}{l}\text { Medium to coarse } \\
\text { grained }\end{array}$ & Granular \\
\hline & & $21 \mathrm{G}-1 \mathrm{~A}, 3-13$ & 79.4 & 79.5 & 2 & G34 & Not recovered & & Troctolite & Medium grained & Granular \\
\hline & & 21G-1A, 13-18 & 79.5 & 79.6 & 3 & G35 & Not recovered & & Troctolite & Medium grained & Granular \\
\hline & & $21 \mathrm{G}-1 \mathrm{~A}, 18-23$ & 79.6 & 79.6 & 4 & G36 & Not recovered & & Troctolite & Medium grained & Granular \\
\hline & & $21 \mathrm{G}-1 \mathrm{~A}, 23-32$ & 79.6 & 79.7 & 5 & G37 & Not recovered & & Troctolite & Medium grained & Granular \\
\hline & & 22R-1A, 0-140 & 89.4 & 90.8 & $\begin{array}{c}1,2,3,4,5 \\
6,7,8,9 \\
10,11,12 \\
13,14\end{array}$ & 29 & Not recovered & & Troctolite & Medium grained & Granular \\
\hline
\end{tabular}




\begin{tabular}{|c|c|c|c|c|c|c|c|c|c|c|c|}
\hline \multirow[b]{2}{*}{ Unit } & \multirow[b]{2}{*}{ Description } & \multirow{2}{*}{$\begin{array}{l}\text { Core, section, } \\
\text { interval }(\mathrm{cm})\end{array}$} & \multicolumn{2}{|c|}{ Depth (mbsf) } & \multirow[b]{2}{*}{ Pieces } & \multirow{2}{*}{$\begin{array}{l}\text { Lithologic } \\
\text { interval }\end{array}$} & \multirow[b]{2}{*}{ Contact type } & \multirow{2}{*}{$\begin{array}{c}\text { Contact } \\
\text { definition }\end{array}$} & \multirow[b]{2}{*}{ Complete lithology name } & \multirow[b]{2}{*}{ Modal grain size } & \multirow[b]{2}{*}{ Texture } \\
\hline & & & Top & Bottom & & & & & & & \\
\hline & & $22 \mathrm{R}-2 \mathrm{~A}, 0-113$ & 90.8 & 91.9 & $\begin{array}{c}1,2,3,4,5 \\
6,7,8\end{array}$ & 29 & Not recovered & & Troctolite & Medium grained & Granular \\
\hline & & $22 \mathrm{R}-2 \mathrm{~A}, 113-116$ & 91.9 & 92.0 & 8 & 30 & Modal and textural & Gradational & Olivine gabbro & Fine grained & Poikilitic-granular \\
\hline & & $22 \mathrm{R}-2 \mathrm{~A}, 116-133$ & 92.0 & 92.1 & $9,10,11$ & 31 & Not recovered & & Troctolite & $\begin{array}{l}\text { Medium to coarse } \\
\text { grained }\end{array}$ & Granular \\
\hline & & 22R-3A, 0-55 & 92.1 & 92.7 & $1,2,3,4,5$ & 31 & Not recovered & & Troctolite & Medium grained & Granular \\
\hline & & 23R-1A, 0-141 & 98.8 & 100.2 & $\begin{array}{c}1,2,3,4,5 \\
6,7,8,9 \\
10,11,12 \\
13,14,15 \\
16,17,18\end{array}$ & 31 & Not recovered & & Troctolite & Medium grained & Granular \\
\hline & & $23 \mathrm{R}-2 \mathrm{~A}, 0-75$ & 100.2 & 101.0 & $\begin{array}{l}1,2,3,4,5 \\
6,7\end{array}$ & 31 & Not recovered & & Troctolite & Medium grained & Granular \\
\hline & & $25 G-1 A, 0-11$ & 79.0 & 79.1 & 1 & G38 & Not recovered & & $\begin{array}{l}\text { Drilling-induced } \\
\text { disaggregated } \\
\text { troctolite }\end{array}$ & & \\
\hline & & $25 \mathrm{G}-1 \mathrm{~A}, 11-20$ & 79.1 & 79.2 & 2 & G39 & Not recovered & & Troctolite & Medium grained & Granular \\
\hline
\end{tabular}

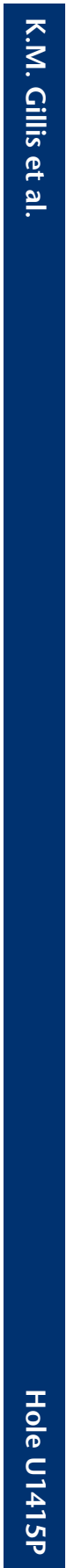


Table T3. Details and explanations for thin sections with two domains, Hole U1415P.

\begin{tabular}{|c|c|c|c|c|c|c|c|c|c|}
\hline $\begin{array}{l}\text { Core, section, } \\
\text { interval }(\mathrm{cm})\end{array}$ & $\begin{array}{l}\text { Thin section } \\
\text { number }\end{array}$ & $\begin{array}{l}\text { Lithologic } \\
\text { interval }\end{array}$ & Rock name & Rock comment & Nature of domains & Contact & $\begin{array}{l}\text { Number } \\
\text { of } \\
\text { domains }\end{array}$ & $\begin{array}{l}\text { Igneous } \\
\text { domain }\end{array}$ & $\begin{array}{c}\text { Domain I lithology } \\
\text { name }\end{array}$ \\
\hline \multicolumn{10}{|l|}{ 345-U1415P- } \\
\hline 4G-1W, 10-13 (Piece 3) & 98 (image) & G11 & Olivine gabbro & With gabbronoritic band & Two lithologies & & 2 & $\begin{array}{l}1 \\
2\end{array}$ & $\begin{array}{l}\text { Olivine gabbro } \\
\text { Gabbronorite (band) }\end{array}$ \\
\hline 4G-1W, 120-125 (Piece 10) & 101 (image) & G18 & Olivine gabbro & $\begin{array}{l}\text { With bands more } \\
\text { troctolitic in character }\end{array}$ & Two lithologies & Sutured & 2 & $\begin{array}{l}1 \\
2\end{array}$ & $\begin{array}{l}\text { Troctolite } \\
\text { Olivine-bearing gabbro }\end{array}$ \\
\hline 6R-2W, 119-122 (Piece 14) & 111 (image) & 9 & Troctolite & $\begin{array}{l}\text { With a patch of coarse- } \\
\text { grained gabbronorite } \\
\text { (only a few mineral } \\
\text { grains) }\end{array}$ & Two lithologies & Sutured & 2 & $\begin{array}{l}1 \\
2\end{array}$ & $\begin{array}{l}\text { Troctolite } \\
\text { Olivine-bearing norite }\end{array}$ \\
\hline 7R-2W, 41-44 (Piece 2) & 114 (image) & 13 & $\begin{array}{l}\text { Contact between } \\
\text { orthopyroxene-bearing } \\
\text { olivine gabbro and an } \\
\text { enclave }\end{array}$ & & Two lithologies & $\begin{array}{l}\text { Sutured, } \\
\text { sharp }\end{array}$ & 2 & $\begin{array}{l}1 \\
2\end{array}$ & $\begin{array}{l}\text { Orthopyroxene-bearing } \\
\text { troctolite } \\
\text { Anorthosite }\end{array}$ \\
\hline 8R-1W, 80-83 (Piece 6) & 116 (image) & 16 & $\begin{array}{l}\text { Olivine gabbro with a } \\
\text { noritic band }\end{array}$ & & Two lithologies & Sutured & 2 & $\begin{array}{l}1 \\
2\end{array}$ & $\begin{array}{l}\text { Troctolite } \\
\text { Norite }\end{array}$ \\
\hline 9R-2W, 20-21 (Piece 3) & 119 (image) & G30 & $\begin{array}{l}\text { Orthopyroxene-bearing } \\
\text { olivine gabbro }\end{array}$ & $\begin{array}{l}\text { Contains two different } \\
\text { lithologies }\end{array}$ & Two lithologies & Sutured & 2 & 1 & $\begin{array}{l}\text { Olivine gabbro } \\
\text { Olivine gabbronorite }\end{array}$ \\
\hline 14R-1W, 22-25 (Piece 3) & 127 (image) & 27 & $\begin{array}{l}\text { Contact between very } \\
\text { heterogeneous olivine } \\
\text { gabbro and an enclave } \\
\text { of orthopyroxene- } \\
\text { bearing olivine gabbro }\end{array}$ & $\begin{array}{l}\text { Part of a very } \\
\text { heterogeneous, } \\
\text { multitextured gabbro }\end{array}$ & Two lithologies & Sutured & 2 & 1 & $\begin{array}{l}\text { Orthopyroxene-bearing } \\
\text { olivine gabbro } \\
\text { Gabbro }\end{array}$ \\
\hline 16R-1W, 117-120 (Piece 10) & 130 (image) & 29 & Troctolite & $\begin{array}{l}\text { With a subvertical } \\
\text { anorthositic vein }\end{array}$ & Two lithologies & Sutured & 2 & $\begin{array}{l}1 \\
2\end{array}$ & $\begin{array}{l}\text { Anorthosite } \\
\text { Troctolite }\end{array}$ \\
\hline 18R-1W, 78-83 (Piece 7) & 134 (image) & 29 & $\begin{array}{l}\text { Contact between } \\
\text { troctolite and } \\
\text { orthopyroxene-bearing } \\
\text { olivine gabbro }\end{array}$ & $\begin{array}{l}\text { Contact between } \\
\text { troctolite and } \\
\text { orthopyroxene-bearing } \\
\text { olivine gabbro }\end{array}$ & Two lithologies & Sutured & 2 & 1 & $\begin{array}{l}\text { Anorthositic troctolite } \\
\text { Orthopyroxene-bearing } \\
\text { olivine gabbro }\end{array}$ \\
\hline 22R-2W, 113-115 (Piece 8) & 140 (image) & $29 / 30$ & $\begin{array}{l}\text { Contact between } \\
\text { troctolite and olivine } \\
\text { gabbro }\end{array}$ & & Two lithologies & Sutured & 2 & $\begin{array}{l}1 \\
2\end{array}$ & $\begin{array}{l}\text { Troctolite } \\
\text { Olivine gabbro }\end{array}$ \\
\hline
\end{tabular}

Table T4. Summary of igneous contacts based on macroscopic and thin section description, Hole U1415P.

\begin{tabular}{|c|c|c|c|c|c|c|}
\hline Unit & $\begin{array}{l}\text { Core, section, } \\
\text { interval }(\mathrm{cm})\end{array}$ & $\begin{array}{l}\text { Thin section } \\
\text { number }\end{array}$ & $\begin{array}{l}\text { Lithologic } \\
\text { interval }\end{array}$ & Contact lithology & Contact type & $\begin{array}{c}\text { Contact } \\
\text { definition }\end{array}$ \\
\hline \multicolumn{7}{|c|}{ 345-U1415P- } \\
\hline I & 7R-2, 9.5-54 (Piece 14) & 114 & 13 & Orthopyroxene-bearing troctolite/Anorthosite & Modal and grain size & Sutured/Sharp \\
\hline II & 14R-1, 16-25.5 (Piece 3) & 127 & 27 & $\begin{array}{l}\text { Orthopyroxene-bearing olivine gabbro/ } \\
\text { Gabbro }\end{array}$ & Modal and grain size & Sutured/Sharp \\
\hline \multirow[t]{2}{*}{ III } & 18R-1, 78-83.5 (Piece 7) & 134 & 29 & $\begin{array}{l}\text { Anorthositic troctolite/orthopyroxene-bearing } \\
\text { olivine gabbro }\end{array}$ & Modal and grain size & Sutured/Sharp \\
\hline & 22R-2, 99-115.5 (Piece 8) & 140 & $29 / 30$ & Troctolite/Olivine gabbro & Modal and grain size & Sutured/Sharp \\
\hline
\end{tabular}




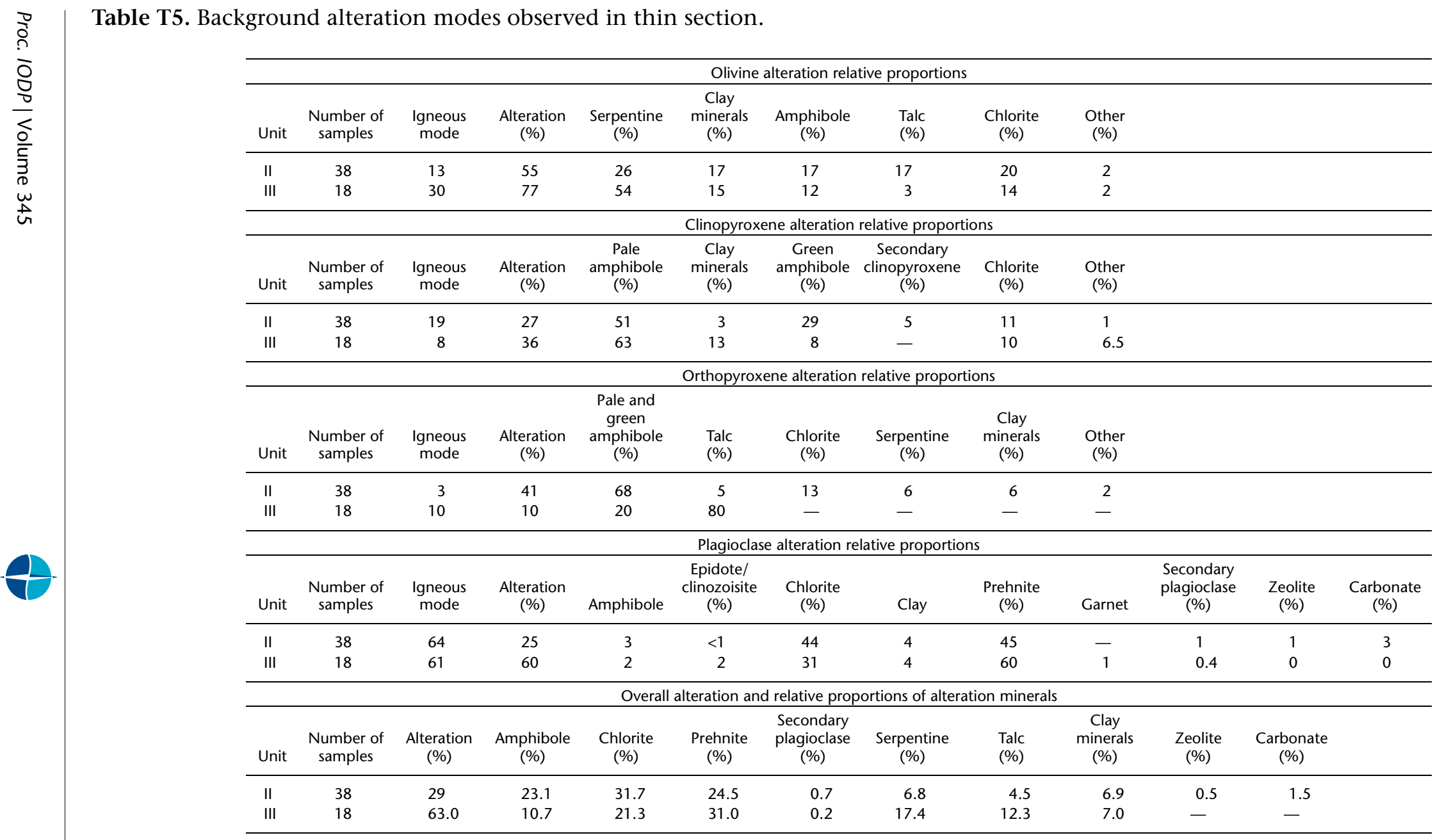


Table T6. Plagioclase alteration observed in thin section, Hole U1415P. (Continued on next page.)

\begin{tabular}{|c|c|c|c|c|c|c|c|c|c|c|c|c|c|c|c|c|}
\hline \multirow{3}{*}{$\begin{array}{l}\text { Core, section, } \\
\text { interval }(\mathrm{cm})\end{array}$} & \multirow{3}{*}{$\begin{array}{l}\text { Thin } \\
\text { section } \\
\text { number }\end{array}$} & \multirow{2}{*}{\multicolumn{2}{|c|}{ Depth (mbsf) }} & \multirow{3}{*}{\multicolumn{2}{|c|}{ 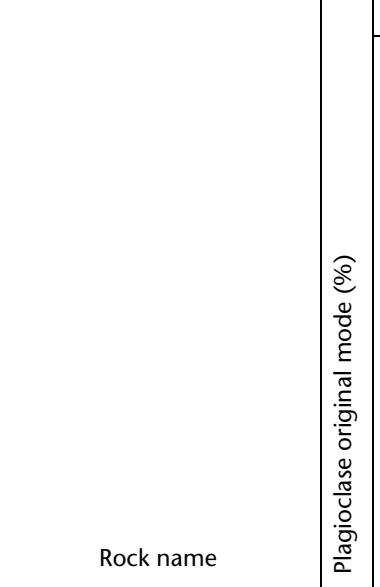 }} & \multicolumn{11}{|c|}{ Alteration (\%) } \\
\hline & & & & & & \multirow{2}{*}{ 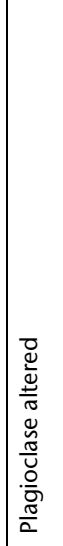 } & \multirow[t]{2}{*}{ 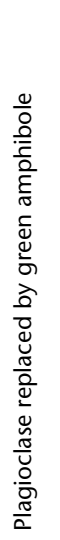 } & \multirow{2}{*}{\multicolumn{2}{|c|}{ 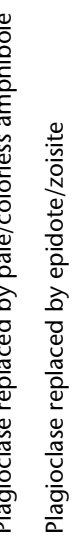 }} & \multirow[t]{2}{*}{ 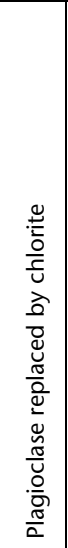 } & \multirow[t]{2}{*}{ 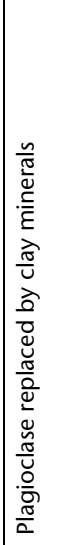 } & \multirow[t]{2}{*}{ 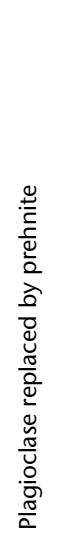 } & \multirow[t]{2}{*}{ 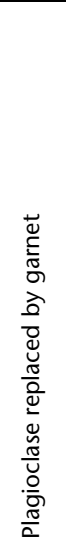 } & \multirow[t]{2}{*}{ 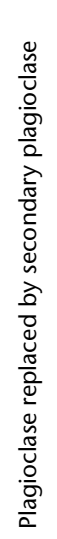 } & 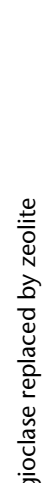 & 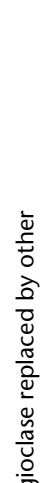 \\
\hline & & Top & Bottom & & & & & & & & & & & & $\frac{\pi}{2}$ & $\frac{\pi}{a}$ \\
\hline 345-U1415P- & & & & & & & & & & & & & & & & \\
\hline 4G-1, 10-13 (Piece 3) & 98 & 12.6 & 12.63 & Gabbronorite & 65 & 2 & & & & 50 & 45 & & & & & 5 \\
\hline 4G-1, 10-13 (Piece 3) & 98 & 12.6 & 12.63 & Olivine gabbro & 70 & 5 & & & & 50 & 45 & & & & & 5 \\
\hline 3R-1, 31-34 (Piece 7) & 96 & 12.81 & 12.84 & Gabbro & 45 & 5 & & & & 100 & & & & & & \\
\hline 4G-1, 41-43 (Piece 6) & 99 & 12.91 & 12.93 & Gabbro & 79 & 10 & & & & 40 & & 20 & & & & 40 \\
\hline 4G-1, 57-60 (Piece 7) & 100 & 13.07 & 13.1 & Oikocryst gabbronorite & 65 & 30 & & & & 40 & & 60 & & & & \\
\hline $3 R-1,120-123$ (Piece 20A) & 97 & 13.7 & 13.73 & Olivine gabbro & 55 & 15 & & & 1 & 70 & & 10 & & 19 & & \\
\hline 4G-1, 120-125 (Piece 10) & 101 & 13.7 & 13.75 & Troctolite & 79 & 5 & & & & 37 & & 60 & & & & 3 \\
\hline 4G-2, 2-3 (Piece 1) & 102 & 13.93 & 13.94 & Olivine gabbro & 55 & 25 & & & & 20 & & 80 & & & & \\
\hline 5R-1, 37-38 (Piece 5) & 103 & 18.47 & 18.48 & Pyroxene-bearing troctolite & 80 & 10 & & & & 50 & & 50 & & & & \\
\hline $5 \mathrm{R}-2,52-53$ (Piece 6$)$ & 104 & 20.04 & 20.05 & Oikocryst gabbro & 55 & 40 & & & & 30 & & 70 & & & & \\
\hline $6 \mathrm{R}-1,47-51$ (Piece 6) & 105 & 23.07 & 23.11 & Olivine gabbro & 50 & 20 & & & & 40 & 10 & 50 & & & & \\
\hline 6R-1, 58-61 (Piece 6) & 106 & 23.18 & 23.21 & Olivine gabbro & 45 & 50 & & & & 80 & & 5 & & 5 & & 10 \\
\hline $6 \mathrm{R}-1,58-61$ (Piece 6) & 106 & 23.18 & 23.21 & Olivine gabbro & 45 & 15 & & & & 5 & & 95 & & & & \\
\hline 6R-1, 101-103 (Piece 7C) & 107 & 23.61 & 23.63 & Olivine gabbro & 53 & 50 & & & & 60 & & 30 & & & & 10 \\
\hline 6R-2, 31-34 (Piece 3) & 108 & 24.315 & 24.345 & Gabbro & 56 & 40 & & & & 40 & & 60 & & & & \\
\hline 6R-2, 38-41 (Piece 4) & 109 & 24.385 & 24.415 & Metagabbro & 65 & 40 & & & & 30 & & 70 & & & & \\
\hline 6R-2, 90-91 (Piece 11) & 110 & 24.905 & 24.915 & Gabbro & 60 & 10 & & & & 25 & & 75 & & & & \\
\hline 6R-2, 119-122 (Piece 14) & 111 & 25.195 & 25.225 & Gabbro & 60 & 10 & & & & 40 & 35 & 20 & & & & 5 \\
\hline 6R-2, 119-122 (Piece 14) & 111 & 25.195 & 25.225 & Troctolite & 79 & 5 & & & & 40 & 35 & 20 & & & & 5 \\
\hline 7R-1, 60-62 (Piece 8A) & 112 & 27.7 & 27.72 & Gabbro & 50 & 40 & & & & 50 & & 50 & & & & \\
\hline 7R-1, 110-112 (Piece 11C) & 113 & 28.2 & 28.22 & Gabbro & 38 & 5 & & & & 30 & & 70 & & & & \\
\hline 7R-2, 41-44 (Piece 2) & 114 & 28.9 & 28.93 & Troctolite & 83 & 10 & & & & 90 & & & & & & 10 \\
\hline 8R-1, 3-4 (Piece 1) & 115 & 31.43 & 31.44 & Olivine gabbro & 65 & 15 & & & & 10 & & 90 & & & & \\
\hline 8R-1, 80-83 (Piece 6) & 116 & 32.2 & 32.23 & Olivine gabbro & 70 & 15 & & & & 40 & & 40 & & 20 & & \\
\hline 9R-1, 3-4 (Piece 1) & 117 & 36.43 & 36.44 & Troctolite & 70 & 20 & & & & 70 & & 30 & & & & \\
\hline 9R-1, 36-41 (Piece 3) & 118 & 36.76 & 36.81 & Gabbro & 73 & 10 & & & & 30 & & 50 & & & & 20 \\
\hline 9R-2, 20-21 (Piece 3) & 119 & 38.015 & 38.025 & Troctolite & 70 & 20 & & & & 60 & & 40 & & & & \\
\hline 10R-1, 60-62 (Piece 7) & 120 & 41.6 & 41.62 & Olivine gabbro & 76 & 10 & & & & 50 & & 50 & & & & \\
\hline 10R-1, 121-134 (Piece 13) & 121 & 42.21 & 42.34 & Olivine gabbro & 60 & 100 & & 10 & & 30 & & 60 & & & & \\
\hline 10R-1, 121-134 (Piece 13) & 121 & 42.21 & 42.34 & Olivine gabbro & 60 & 90 & 10 & 10 & & 60 & & 10 & & 5 & 5 & \\
\hline 10R-1, 137-138 (Piece 14) & 122 & 42.37 & 42.38 & Olivine gabbro & 65 & 50 & & 5 & & 50 & & 40 & & & & 5 \\
\hline 11R-1, 43-44 (Piece 6) & 123 & 46.03 & 46.04 & Gabbro & 65 & 50 & & & & 30 & & 70 & & & & \\
\hline 12R-1, 5-6 (Piece 1) & 124 & 49.75 & 49.76 & Gabbro & 70 & 30 & & & & 50 & & 50 & & & & \\
\hline 13R-1, 39-42 (Piece 5) & 125 & 55.09 & 55.12 & Olivine-bearing gabbro & 75 & 10 & 2 & & & 43 & 10 & 5 & & & 30 & 10 \\
\hline 13R-1, 113-116 (Piece 10) & 126 & 55.83 & 55.86 & Troctolite & 70 & 30 & & & & 40 & 40 & 15 & & & & 5 \\
\hline 14R-1, 22-25 (Piece 3) & 127 & 59.02 & 59.05 & Gabbro & 70 & 20 & & & & 50 & & 50 & & & & \\
\hline 14R-1, 22-25 (Piece 3) & 127 & 59.02 & 59.05 & Troctolite & 65 & 10 & 5 & & & 50 & & 20 & & 5 & & 20 \\
\hline 14R-1, 50-52 (Piece 5) & 128 & 59.3 & 59.32 & Olivine gabbro & 65 & 40 & & & & 20 & 20 & 60 & & & & \\
\hline 16R-1, 47-49 (Piece 6) & 129 & 68.47 & 68.49 & Troctolite & 86 & 10 & & & & 35 & & 65 & & & & \\
\hline 16R-1, 100-102 (Piece 9) & 131 & 69 & 69.02 & Olivine gabbro & 70 & 20 & & 5 & 10 & 20 & & 60 & & 5 & & \\
\hline 16R-1, 117-120 (Piece 10) & 130 & 69.17 & 69.2 & Olivine gabbro & 80 & 25 & & & & 25 & & 75 & & & & \\
\hline 18R-1, 31-36 (Piece 5) & 132 & 77.61 & 77.66 & Troctolite & 45 & 70 & & & & 20 & 10 & 70 & & & & \\
\hline 18R-1, 39-40 (Piece 6) & 133 & 77.69 & 77.7 & Troctolite & 65 & 70 & & & & 20 & 10 & 70 & & & & \\
\hline 20R-1, 3-6 (Piece 1) & 135 & 82.33 & 82.36 & Troctolite & 45 & 75 & & 5 & & 80 & & 15 & & & & \\
\hline 20R-1, 67-68 (Piece 5) & 136 & 82.97 & 82.98 & Troctolite & 55 & 70 & & & & 20 & 10 & 70 & & & & \\
\hline 20R-2, 59-61 (Piece 6) & 137 & 84.27 & 84.29 & Troctolite & 65 & 80 & & & & 20 & 10 & 70 & & & & \\
\hline 22R-1, 12-17 (Piece 3) & 138 & 89.52 & 89.57 & Troctolite & 57 & 70 & & & & 30 & & 70 & & & & \\
\hline 22R-1, 60-65 (Piece 8) & 139 & 90 & 90.05 & Olivine gabbro & 65 & 80 & & 10 & 25 & 30 & & 30 & 5 & & & \\
\hline 22R-1, 60-65 (Piece 8) & 139 & 90 & 90.05 & Troctolite & 30 & 70 & & & & 10 & & 75 & 15 & & & \\
\hline 22R-2, 113-115 (Piece 8) & 140 & 91.93 & 91.95 & Ol-gabbro & 30 & 30 & & & & 30 & & 50 & & 20 & & \\
\hline 22R-2, 113-115 (Piece 8) & 140 & 91.93 & 91.95 & Troctolite & 57 & 100 & & & & & 10 & 90 & & & & \\
\hline
\end{tabular}


Table T6 (continued).

\begin{tabular}{|c|c|c|c|c|c|c|c|c|c|c|c|c|c|c|c|c|}
\hline \multirow{3}{*}{$\begin{array}{l}\text { Core, section, } \\
\text { interval }(\mathrm{cm})\end{array}$} & \multirow{3}{*}{$\begin{array}{l}\text { Thin } \\
\text { section } \\
\text { number }\end{array}$} & \multirow{2}{*}{\multicolumn{2}{|c|}{ Depth (mbsf) }} & \multirow[b]{3}{*}{ Rock name } & \multirow{3}{*}{ 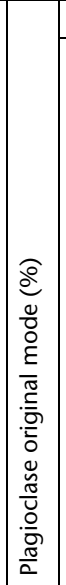 } & \multicolumn{11}{|c|}{ Alteration (\%) } \\
\hline & & & & & & \multirow[t]{2}{*}{ 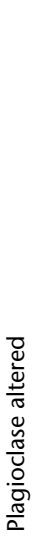 } & \multirow[t]{2}{*}{ 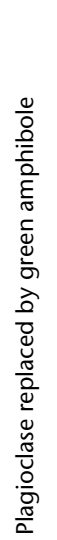 } & \multirow[t]{2}{*}{ 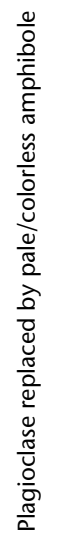 } & \multirow[t]{2}{*}{ 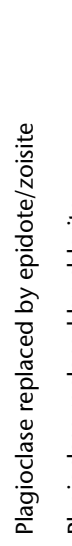 } & \multirow{2}{*}{\multicolumn{2}{|c|}{ 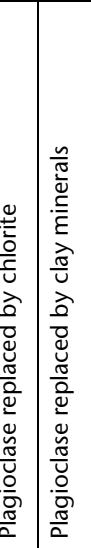 }} & \multirow[t]{2}{*}{ 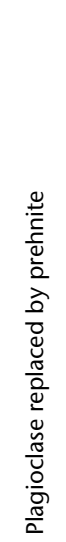 } & \multirow[t]{2}{*}{ 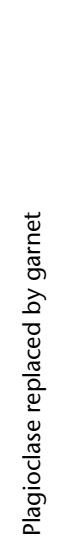 } & \multirow{2}{*}{\multicolumn{2}{|c|}{ 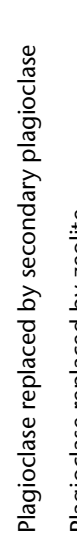 }} & 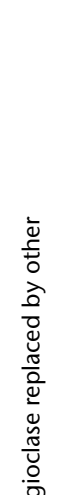 \\
\hline & & Top & Bottom & & & & & & & & & & & & & $\frac{\pi}{a}$ \\
\hline 23R-1, 19-21 (Piece 2) & 141 & 98.99 & 99.01 & Troctolite & 55 & 50 & & & & 50 & & 50 & & & & \\
\hline 23R-1, 19-21 (Piece 2) & 141 & 98.99 & 99.01 & Troctolite & 88 & 80 & & & & 50 & & 50 & & & & \\
\hline 23R-1, 100-103 (Piece 14) & 142 & 99.8 & 99.83 & Altered olivine gabbro & 60 & 90 & & 10 & & 30 & & 40 & & & & 20 \\
\hline 23R-1, 134-138 (Piece 18) & 143 & 100.14 & 100.18 & Troctolite & 70 & 70 & & & & 50 & & 50 & & & & \\
\hline
\end{tabular}

Table T7. Metamorphic domains described in thin section, Hole U1415P.

\begin{tabular}{|c|c|c|c|c|c|c|c|c|}
\hline \multirow{2}{*}{$\begin{array}{l}\text { Core, section, } \\
\text { interval }(\mathrm{cm})\end{array}$} & \multirow{2}{*}{$\begin{array}{l}\text { Thin section } \\
\text { number }\end{array}$} & \multicolumn{2}{|c|}{ Depth (mbsf) } & \multirow[b]{2}{*}{ Rock name } & \multirow{2}{*}{$\begin{array}{c}\text { Number } \\
\text { of } \\
\text { domains }\end{array}$} & \multirow{2}{*}{$\begin{array}{l}\text { Alteration } \\
\text { domain }\end{array}$} & \multirow{2}{*}{$\begin{array}{c}\text { Domain } \\
\text { relative } \\
\text { abundance } \\
(\%)\end{array}$} & \multirow{2}{*}{$\begin{array}{l}\text { Alteration } \\
\text { domain } \\
\text { or feature }\end{array}$} \\
\hline & & Top & Bottom & & & & & \\
\hline \multicolumn{9}{|l|}{ 345-U1415P- } \\
\hline \multirow[t]{2}{*}{ 14R-1W, 22-25 (Piece 3) } & 127 (image) & 59.02 & 59.05 & Gabbro & 2 & 2 & 40 & Background \\
\hline & & & & Troctolite & & 1 & 60 & Background \\
\hline \multirow[t]{2}{*}{ 4G-1W, 10-13 (Piece 3) } & 98 (image) & 12.60 & 12.63 & Gabbronorite & 2 & 2 & 60 & Background \\
\hline & & & & Olivine gabbro & & 1 & 40 & Background \\
\hline \multirow[t]{2}{*}{ 6R-1W, 58-61 (Piece 6) } & 106 (image) & 23.18 & 23.21 & Olivine gabbro & 2 & 1 & 30 & Halo \\
\hline & & & & & & 2 & 70 & Background \\
\hline \multirow[t]{2}{*}{ 6R-2W, 119-122 (Piece 14) } & 111 (image) & 25.20 & 25.23 & Gabbro & 2 & 2 & 30 & Background \\
\hline & & & & Troctolite & & 1 & 70 & Background \\
\hline \multirow[t]{2}{*}{ 10R-1W, 121-134 (Piece 13) } & 121 (image) & 42.21 & 42.34 & Olivine gabbro & 2 & 1 & 30 & Cataclasite zone \\
\hline & & & & & & 2 & 70 & Background \\
\hline \multirow[t]{2}{*}{ 22R-1W, 60-65 (Piece 8) } & 139 (image) & 90.00 & 90.05 & Olivine gabbro & 2 & 1 & 50 & Background \\
\hline & & & & Troctolite & & 2 & 50 & Background \\
\hline \multirow[t]{2}{*}{ 22R-2W, 113-115 (Piece 8) } & 140 (image) & 91.93 & 91.95 & Olivine gabbro & 2 & 1 & 60 & Background \\
\hline & & & & Troctolite & & 2 & 40 & Background \\
\hline \multirow[t]{2}{*}{ 23R-1W, 19-21 (Piece 2) } & 141 (image) & 98.99 & 99.01 & Troctolite & 2 & 1 & 30 & Background \\
\hline & & & & Anorthosite & & 2 & 70 & Background \\
\hline
\end{tabular}


Table T8. Primary mineralogy based on X-ray diffraction analysis of vein-filling materials and cataclasites, Hole U1415P.

\begin{tabular}{cclc}
\hline $\begin{array}{c}\text { Core, section, } \\
\text { interval }(\mathrm{cm})\end{array}$ & Sample ID & $\begin{array}{c}\text { Minerals in } \\
\text { descending order } \\
\text { of abundance }\end{array}$ & \multicolumn{1}{c}{ Comment } \\
\hline $\begin{array}{c}\text { 345-U1415P- } \\
\text { 5R-1, 29-31 }\end{array}$ & WDGE4587171 & $\begin{array}{l}\text { Plagioclase } \\
\text { Chlorite } \\
\text { Lizardite } \\
\text { Diopside } \\
\text { Talc }\end{array}$ & \\
23R-1, 100-103 & OTHR4593371 & $\begin{array}{l}\text { Diopside } \\
\text { Chlorite }\end{array}$ & White vein material \\
23R-2, 34-35 & OTHR4593361 & $\begin{array}{l}\text { Lizardite } \\
\text { Rectorite } \\
\text { Nontronite }\end{array}$ & \\
& & Green vein material \\
\hline
\end{tabular}


Table T9. Discrete sample remanence data, Hole U1415P.

\begin{tabular}{|c|c|c|c|c|c|c|c|c|c|c|c|c|c|c|}
\hline \multirow[b]{2}{*}{$\begin{array}{l}\text { Core, section, } \\
\text { interval }(\mathrm{cm})\end{array}$} & \multirow[b]{2}{*}{$\begin{array}{l}\text { Depth } \\
\text { (mbsf) }\end{array}$} & \multirow[b]{2}{*}{ Lithology } & \multicolumn{3}{|c|}{ NRM } & \multicolumn{9}{|c|}{ Principal component analysis } \\
\hline & & & $\begin{array}{l}\text { Declination } \\
\left({ }^{\circ}\right)\end{array}$ & $\begin{array}{c}\text { Inclination } \\
\left({ }^{\circ}\right)\end{array}$ & $\begin{array}{l}\text { Intensity } \\
(\mathrm{A} / \mathrm{m})\end{array}$ & Treatment & Low & High & $\begin{array}{c}n \\
\text { points }\end{array}$ & Origin model & $\begin{array}{l}\text { MAD } \\
\left({ }^{\circ}\right)\end{array}$ & $\begin{array}{c}\text { Declination } \\
\left(^{\circ}\right)\end{array}$ & $\begin{array}{c}\text { Inclination } \\
\left({ }^{\circ}\right)\end{array}$ & $\begin{array}{l}\text { Intensity } \\
(A / m)\end{array}$ \\
\hline \multicolumn{15}{|l|}{ 345-U1415P- } \\
\hline \multirow[t]{2}{*}{$3 R-1,68$} & 13.18 & Olivine gabbro & 154.5 & 35.7 & $8.28 \mathrm{E}-01$ & LTD/Th & 77.1 & 560 & 15 & $\mathrm{~F}$ & 6.6 & 119.3 & -35.4 & 4.13E-01 \\
\hline & & & & & & & 560 & 590 & 4 & $\mathrm{~F}$ & 4.4 & 113.8 & -58.3 & $5.13 \mathrm{E}-01$ \\
\hline $3 \mathrm{R}-1,71$ & 13.21 & Olivine gabbro & 183.2 & 34.8 & $7.75 \mathrm{E}-01$ & $\mathrm{AF}$ & 15 & 50 & 8 & $\mathrm{~F}$ & 3.8 & 134.7 & -46.6 & $2.14 \mathrm{E}-01$ \\
\hline $4 \mathrm{G}-1,14$ & 12.64 & Orthopyroxene-bearing olivine gabbro & 190.1 & 61.4 & $3.33 \mathrm{E}+00$ & LTD/Th & 550 & 590 & 5 & $\mathrm{~F}$ & 6.6 & 239.4 & -44.7 & $8.69 \mathrm{E}-01$ \\
\hline $4 \mathrm{G}-1,96$ & 13.46 & Olivine gabbro & 301.3 & -7.7 & 4.90E-01 & LTD/Th & 150 & 590 & 16 & $\mathrm{~F}$ & 2.5 & 314.1 & -32.1 & $1.70 \mathrm{E}+00$ \\
\hline \multirow[t]{2}{*}{$4 \mathrm{G}-1,99$} & 13.49 & Olivine gabbro & 183.3 & 10.6 & $3.16 \mathrm{E}+00$ & $\mathrm{AF}$ & 2 & 10 & 3 & $\mathrm{~F}$ & 0.3 & 166.7 & 17.8 & 7.53E-01 \\
\hline & & & & & & & 25 & 40 & 4 & A & 2.6 & 324.9 & -74.5 & $7.58 \mathrm{E}-02$ \\
\hline $4 \mathrm{G}-2,6$ & 13.97 & Olivine gabbro & 124.1 & 35.7 & $1.71 \mathrm{E}+00$ & LTD/Th & 560 & 590 & 4 & $\mathrm{~F}$ & 6.4 & 113.9 & -0.9 & $2.09 \mathrm{E}-01$ \\
\hline \multirow[t]{2}{*}{$5 R-1,39$} & 18.49 & Orthopyroxene-bearing olivine gabbro & 170.3 & 63.3 & $2.91 \mathrm{E}-01$ & LTD/Th & 425 & 510 & 5 & $\mathrm{~F}$ & 5.4 & 171.3 & -13.5 & $5.22 \mathrm{E}-02$ \\
\hline & & & & & & & 500 & 580 & 9 & A & 3 & 105.3 & -44.6 & 1.07E-01 \\
\hline $5 R-2,51$ & 20.03 & Orthopyroxene-bearing olivine gabbro & 249.7 & -6.1 & 7.43E-01 & LTD/Th & 77.1 & 590 & 18 & $\mathrm{~F}$ & 4.3 & 1.6 & -58.9 & $2.01 \mathrm{E}+00$ \\
\hline $6 \mathrm{R}-1,72$ & 23.32 & Olivine gabbro & 150.1 & 51.4 & $4.21 \mathrm{E}-01$ & LTD/Th & 77.2 & 590 & 17 & $\mathrm{~F}$ & 4.1 & 154.4 & -45.9 & $1.15 \mathrm{E}+00$ \\
\hline 6R-2, 92 & 24.93 & Troctolitic olivine gabbro & 96.4 & 12.1 & $9.06 \mathrm{E}-01$ & LTD/Th & 425 & 590 & 12 & $\mathrm{~F}$ & 1.7 & 80.6 & -61.7 & $2.57 \mathrm{E}+00$ \\
\hline \multirow[t]{2}{*}{ 7R-1, 113} & 28.23 & Orthopyroxene-bearing olivine gabbro & 178.4 & -22.8 & $8.74 \mathrm{E}-02$ & LTD/Th & 425 & 500 & 4 & $\mathrm{~F}$ & 3.7 & 142.7 & -63.5 & $1.08 \mathrm{E}-01$ \\
\hline & & & & & & & 500 & 580 & 9 & $\mathrm{~F}$ & 1.8 & 359.9 & -26.8 & $6.63 \mathrm{E}-02$ \\
\hline $7 R-2,3$ & 28.52 & Orthopyroxene-bearing olivine gabbro & 232.3 & 53.0 & $4.52 \mathrm{E}-01$ & LTD/Th & 77.2 & 580 & 16 & $\mathrm{~F}$ & 2.2 & 69.9 & -20.2 & $1.39 \mathrm{E}+00$ \\
\hline $8 \mathrm{R}-1,5$ & 31.45 & Olivine gabbro & 228.0 & 41.5 & $2.85 \mathrm{E}-01$ & LTD/Th & 150 & 590 & 16 & $\mathrm{~F}$ & 6.5 & 234.3 & 18.6 & $5.29 \mathrm{E}-01$ \\
\hline \multirow[t]{2}{*}{$9 \mathrm{R}-1,6$} & 36.46 & Olivine gabbro & 247.0 & 40.9 & $7.81 \mathrm{E}-01$ & LTD/Th & 350 & 520 & 7 & $\mathrm{~F}$ & 4.6 & 298.2 & -41.1 & $2.98 \mathrm{E}-01$ \\
\hline & & & & & & & 550 & 590 & 5 & $\mathrm{~F}$ & 3.7 & 337.9 & -62.7 & 4.76E-01 \\
\hline \multirow[t]{2}{*}{$9 \mathrm{R}-2,22$} & 38.04 & Orthopyroxene-bearing olivine gabbro & 275.3 & 9.8 & 4.64E-01 & LTD/Th & 250 & 520 & 8 & $\mathrm{~F}$ & 10.9 & 216.5 & 60.8 & $5.50 \mathrm{E}-02$ \\
\hline & & & & & & & 510 & 580 & 8 & $\mathrm{~F}$ & 10.5 & 249.9 & -48.2 & 9.97E-02 \\
\hline \multirow[t]{2}{*}{ 10R-1, 139} & 42.39 & Orthopyroxene-bearing olivine gabbro & 175.0 & 58.5 & $4.84 \mathrm{E}-01$ & LTD/Th & 250 & 500 & 6 & $\mathrm{~F}$ & 8.1 & 184.9 & -36.2 & $1.34 \mathrm{E}-01$ \\
\hline & & & & & & & 540 & 590 & 6 & A & 4.1 & 128.9 & -70.4 & 2.03E-01 \\
\hline 10R-2, 2 & 42.45 & Orthopyroxene-bearing olivine gabbro & 282.4 & 39.1 & $1.66 \mathrm{E}+00$ & LTD/Th & 560 & 590 & 4 & $\mathrm{~F}$ & 1.9 & 279.5 & 3.9 & $3.78 \mathrm{E}-01$ \\
\hline $11 \mathrm{R}-1,45$ & 46.05 & Orthopyroxene-bearing olivine gabbro & 318.2 & 64.2 & $1.75 \mathrm{E}+00$ & LTD/Th & 560 & 590 & 4 & $\mathrm{~F}$ & 5.7 & 229.2 & -36.8 & $3.86 \mathrm{E}-01$ \\
\hline $12 \mathrm{R}-1,7$ & 49.77 & Orthopyroxene-bearing olivine gabbro & 204.0 & 72.0 & $1.30 \mathrm{E}+00$ & LTD/Th & 550 & 590 & 5 & $\mathrm{~F}$ & 4.2 & 312.6 & -53.7 & $1.10 \mathrm{E}+00$ \\
\hline \multirow{2}{*}{$13 \mathrm{R}-1,17$} & 54.87 & Olivine gabbro & 301.2 & 65.5 & $8.71 \mathrm{E}-01$ & LTD/Th & 77.1 & 540 & 13 & $\mathrm{~F}$ & 5.5 & 149.5 & -40.2 & 4.09E-01 \\
\hline & & & & & & & 540 & 590 & 6 & $\mathrm{~F}$ & 2.1 & 170.4 & -48.0 & $7.26 \mathrm{E}-01$ \\
\hline 13R-1, 117 & 55.87 & Olivine gabbro & 166.8 & 63.8 & $2.37 E+00$ & LTD/Th & 550 & 590 & 5 & $\mathrm{~F}$ & 3.1 & 13.7 & -59.3 & $6.68 \mathrm{E}-01$ \\
\hline \multirow{2}{*}{$14 \mathrm{R}-1,37$} & 59.17 & Olivine gabbro & 273.3 & 36.5 & $5.78 \mathrm{E}-01$ & LTD/Th & 350 & 475 & 4 & $\mathrm{~F}$ & 4 & 315.2 & -41.7 & 4.06E-01 \\
\hline & & & & & & & 475 & 590 & 11 & $\mathrm{~F}$ & 2.1 & 68.4 & -84.5 & $1.15 \mathrm{E}+00$ \\
\hline $14 \mathrm{R}-2,12$ & 60.21 & Olivine gabbro & 314.3 & -51.6 & $4.68 \mathrm{E}-01$ & LTD/Th & 350 & 530 & 8 & $\mathrm{~F}$ & 2.7 & 330.2 & -51.8 & $4.29 \mathrm{E}-01$ \\
\hline 14R-2, 21 & 60.30 & Olivine gabbro & 218.1 & -49.2 & $6.52 \mathrm{E}-01$ & LTD/Th & 425 & 530 & 7 & $\mathrm{~F}$ & 1.3 & 212.0 & -49.5 & $5.55 \mathrm{E}-01$ \\
\hline $15 R-1,3$ & 63.83 & Olivine gabbro & 215.1 & 74.0 & $3.59 \mathrm{E}+00$ & LTD/Th & 540 & 590 & 6 & A & 4.1 & 136.0 & 47.4 & 2.95E-01 \\
\hline 16R-1, 46 & 68.46 & Troctolite & 351.7 & 52.2 & 4. $27 \mathrm{E}+00$ & LTD/Th & 540 & 590 & 6 & A & 1.2 & 358.3 & -8.2 & $2.75 \mathrm{E}+00$ \\
\hline 18R-1, 41 & 77.71 & Troctolite & 253.0 & 28.0 & $1.06 \mathrm{E}+00$ & LTD/Th & 530 & 590 & 7 & $\mathrm{~F}$ & 2.9 & 265.9 & -51.6 & $6.54 \mathrm{E}-01$ \\
\hline 20R-1, 68 & 82.98 & Troctolite & 279.4 & 62.6 & $8.39 \mathrm{E}+00$ & LTD/Th & 425 & 580 & 12 & $\mathrm{~F}$ & 5.6 & 193.0 & -43.6 & $2.57 \mathrm{E}+00$ \\
\hline 20R-2, 58 & 84.26 & Troctolite & 217.3 & 53.6 & $2.47 \mathrm{E}+00$ & LTD/Th & 520 & 580 & 7 & $\mathrm{~F}$ & 2.5 & 205.5 & -39.6 & $9.63 \mathrm{E}-01$ \\
\hline $22 \mathrm{R}-1,117$ & 90.57 & Troctolite & 184.2 & 61.3 & $6.47 \mathrm{E}+00$ & LTD/Th & 540 & 570 & 4 & A & 5.4 & 172.5 & 11.7 & $6.26 \mathrm{E}-01$ \\
\hline $22 \mathrm{R}-2,32$ & 91.12 & Troctolite & 72.0 & 42.2 & $2.51 \mathrm{E}+00$ & LTD/Th & 475 & 570 & 9 & $\mathrm{~F}$ & 2 & 52.1 & -28.7 & $6.90 \mathrm{E}-01$ \\
\hline $22 \mathrm{R}-3,17$ & 92.30 & Troctolite & 257.7 & 60.4 & $4.95 \mathrm{E}+00$ & LTD/Th & 540 & 570 & 4 & $\mathrm{~F}$ & 2.1 & 274.7 & -17.0 & $9.37 \mathrm{E}-01$ \\
\hline $23 \mathrm{R}-1,68$ & 99.48 & Troctolite & 257.8 & 53.3 & 3.167665 & LTD/Th & 520 & 570 & 6 & $\mathrm{~F}$ & 1.8 & 276.8 & -25.4 & $9.99 \mathrm{E}-01$ \\
\hline $23 \mathrm{R}-2,56$ & 100.77 & Troctolite & 108.1 & 54.4 & 4.24475 & LTD/Th & 520 & 570 & 5 & $\mathrm{~F}$ & 2.3 & 95.9 & -24.0 & $9.00 \mathrm{E}-01$ \\
\hline
\end{tabular}

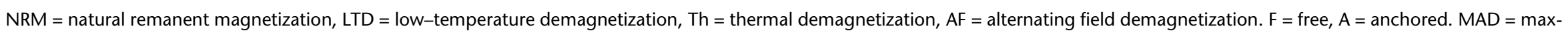


Table T10. Anisotropy of magnetic susceptibility data, Hole U1415P.

\begin{tabular}{|c|c|c|c|c|c|c|c|c|c|c|c|c|c|c|}
\hline \multirow[b]{2}{*}{$\begin{array}{l}\text { Core, section, } \\
\text { interval }(\mathrm{cm})\end{array}$} & \multirow[b]{2}{*}{$\begin{array}{l}\text { Depth } \\
\text { (mbsf) }\end{array}$} & \multirow[b]{2}{*}{ Lithology } & \multirow[b]{2}{*}{$\begin{array}{l}\text { Susceptibility } \\
\text { (SI) }\end{array}$} & \multicolumn{3}{|c|}{ Maximum } & \multicolumn{3}{|c|}{ Intermediate } & \multicolumn{3}{|c|}{ Minimum } & \multirow{2}{*}{$\begin{array}{c}\text { Corrected } \\
\text { anisotropy } \\
\text { degree }\end{array}$} & \multirow[b]{2}{*}{$\begin{array}{c}\text { Shape } \\
\text { parameter }\end{array}$} \\
\hline & & & & Eigenvalue & $\begin{array}{l}\text { Declination } \\
\left(^{\circ}\right)\end{array}$ & $\begin{array}{c}\text { Inclination } \\
\left(^{\circ}\right)\end{array}$ & Eigenvalue & $\begin{array}{l}\text { Declination } \\
\left(^{\circ}\right)\end{array}$ & $\begin{array}{c}\text { Inclination } \\
\left(^{\circ}\right)\end{array}$ & Eigenvalue & $\begin{array}{l}\text { Declination } \\
\left({ }^{\circ}\right)\end{array}$ & $\begin{array}{c}\text { Inclination } \\
\left({ }^{\circ}\right)\end{array}$ & & \\
\hline \multicolumn{15}{|l|}{ 345-U1415P- } \\
\hline $3 R-1,68$ & 13.18 & Olivine gabbro & $9.38 \mathrm{E}-03$ & 0.3735 & 297.9 & 20.5 & 0.3346 & 200.9 & 18.1 & 0.2919 & 72.8 & 62.0 & 1.28 & 0.11 \\
\hline $3 R-1,71$ & 13.21 & Olivine gabbro & $9.54 \mathrm{E}-03$ & 0.3607 & 305.8 & 15.1 & 0.3459 & 210.6 & 18.7 & 0.2934 & 72.4 & 65.6 & 1.24 & 0.59 \\
\hline $4 \mathrm{G}-1,14$ & 12.64 & $\begin{array}{l}\text { Orthopyroxene-bearing } \\
\text { olivine gabbro }\end{array}$ & 1.79E-02 & 0.3719 & 163.8 & 4.7 & 0.3480 & 70.2 & 37.8 & 0.2801 & 259.8 & 51.8 & 1.35 & 0.53 \\
\hline 4G-1, 96 & 13.46 & Olivine gabbro & $8.56 \mathrm{E}-03$ & 0.3529 & 85.9 & 19.1 & 0.3332 & 353.9 & 5.7 & 0.3139 & 247.9 & 70.0 & 1.12 & 0.02 \\
\hline $4 \mathrm{G}-1,99$ & 13.49 & Olivine gabbro & 1.07E-02 & 0.3451 & 69.8 & 15.0 & 0.3351 & 163.4 & 13.0 & 0.3198 & 292.4 & 70.0 & 1.08 & 0.23 \\
\hline $4 G-2,6$ & 13.97 & Olivine gabbro & $6.80 \mathrm{E}-03$ & 0.3650 & 130.5 & 14.3 & 0.3365 & 30.9 & 33.0 & 0.2986 & 240.4 & 53.3 & 1.22 & 0.19 \\
\hline $5 \mathrm{R}-1,39$ & 18.49 & $\begin{array}{l}\text { Orthopyroxene-bearing } \\
\text { olivine gabbro }\end{array}$ & $5.19 \mathrm{E}-03$ & 0.3794 & 185.0 & 15.8 & 0.3286 & 278.2 & 11.3 & 0.2920 & 42.4 & 70.4 & 1.30 & -0.10 \\
\hline $5 R-2,51$ & 20.03 & $\begin{array}{l}\text { Orthopyroxene-bearing } \\
\text { olivine gabbro }\end{array}$ & $1.25 \mathrm{E}-02$ & 0.3691 & 183.5 & 4.1 & 0.3208 & 93.5 & 0.1 & 0.3102 & 1.5 & 85.9 & 1.20 & -0.61 \\
\hline $6 \mathrm{R}-1,72$ & 23.32 & Olivine gabbro & 1.10E-02 & 0.3768 & 226.7 & 6.3 & 0.3261 & 136.3 & 4.3 & 0.2970 & 12.3 & 82.4 & 1.27 & -0.21 \\
\hline $6 \mathrm{R}-2,92$ & 24.93 & Troctolitic olivine gabbro & $2.19 \mathrm{E}-02$ & 0.3548 & 229.2 & 6.2 & 0.3397 & 138.0 & 10.4 & 0.3055 & 349.4 & 77.8 & 1.17 & 0.42 \\
\hline 7R-1, 113 & 28.23 & $\begin{array}{l}\text { Orthopyroxene-bearing } \\
\text { olivine gabbro }\end{array}$ & $8.95 \mathrm{E}-04$ & 0.3609 & 332.9 & 46.0 & 0.3355 & 210.6 & 27.3 & 0.3036 & 102.2 & 31.4 & 1.19 & 0.15 \\
\hline $7 R-2,3$ & 28.52 & $\begin{array}{l}\text { Orthopyroxene-bearing } \\
\text { olivine gabbro }\end{array}$ & $3.13 \mathrm{E}-03$ & 0.3650 & 305.6 & 17.0 & 0.3349 & 211.1 & 14.4 & 0.3001 & 82.9 & 67.4 & 1.22 & 0.12 \\
\hline $8 \mathrm{R}-1,5$ & 31.45 & Olivine gabbro & $4.10 \mathrm{E}-03$ & 0.3618 & 323.5 & 21.5 & 0.3532 & 229.6 & 9.8 & 0.2851 & 116.6 & 66.2 & 1.30 & 0.80 \\
\hline $9 \mathrm{R}-1,6$ & 36.46 & Olivine gabbro & $8.33 \mathrm{E}-03$ & 0.3576 & 13.9 & 17.3 & 0.3348 & 283.2 & 2.2 & 0.3075 & 186.1 & 72.6 & 1.16 & 0.13 \\
\hline $9 \mathrm{R}-2,22$ & 38.04 & $\begin{array}{l}\text { Orthopyroxene-bearing } \\
\text { olivine gabbro }\end{array}$ & $1.15 \mathrm{E}-02$ & 0.3636 & 57.2 & 18.3 & 0.3370 & 318.5 & 24.4 & 0.2995 & 180.2 & 58.7 & 1.22 & 0.22 \\
\hline $10 \mathrm{R}-1,139$ & 42.39 & $\begin{array}{l}\text { Orthopyroxene-bearing } \\
\text { olivine gabbro }\end{array}$ & 8.97E-03 & 0.3589 & 210.3 & 16.2 & 0.3315 & 119.4 & 3.3 & 0.3096 & 18.3 & 73.4 & 1.16 & -0.08 \\
\hline $10 \mathrm{R}-2,2$ & 42.45 & $\begin{array}{l}\text { Orthopyroxene-bearing } \\
\text { olivine gabbro }\end{array}$ & $1.16 \mathrm{E}-02$ & 0.3694 & 68.6 & 25.4 & 0.3218 & 336.5 & 4.4 & 0.3088 & 237.4 & 64.1 & 1.21 & -0.54 \\
\hline $11 \mathrm{R}-1,45$ & 46.05 & $\begin{array}{l}\text { Orthopyroxene-bearing } \\
\text { olivine gabbro }\end{array}$ & $1.08 \mathrm{E}-02$ & 0.3612 & 301.7 & 16.8 & 0.3359 & 39.9 & 25.3 & 0.3029 & 181.6 & 58.9 & 1.19 & 0.18 \\
\hline $12 \mathrm{R}-1,7$ & 49.77 & $\begin{array}{l}\text { Orthopyroxene-bearing } \\
\text { olivine gabbro }\end{array}$ & $1.40 \mathrm{E}-02$ & 0.3537 & 103.4 & 24.5 & 0.3289 & 200.5 & 15.3 & 0.3174 & 319.6 & 60.6 & 1.12 & -0.34 \\
\hline 13R-1, 17 & 54.87 & Olivine gabbro & $7.91 \mathrm{E}-03$ & 0.3632 & 292.6 & 49.1 & 0.3271 & 127.8 & 39.9 & 0.3097 & 31.4 & 7.6 & 1.18 & -0.31 \\
\hline 13R-1, 117 & 55.87 & Olivine gabbro & $1.65 \mathrm{E}-02$ & 0.3573 & 327.2 & 10.4 & 0.3288 & 169.4 & 78.7 & 0.3139 & 58.0 & 4.2 & 1.14 & -0.28 \\
\hline 14R-1, 37 & 59.17 & Olivine gabbro & $9.25 \mathrm{E}-03$ & 0.3565 & 303.8 & 18.1 & 0.3262 & 64.8 & 57.7 & 0.3172 & 204.7 & 25.8 & 1.13 & -0.52 \\
\hline $14 \mathrm{R}-2,12$ & 60.21 & Olivine gabbro & 1.07E-03 & 0.3601 & 145.9 & 1.6 & 0.3291 & 52.5 & 64.7 & 0.3108 & 236.7 & 25.2 & 1.16 & -0.22 \\
\hline 14R-2, 21 & 60.30 & Olivine gabbro & $1.71 \mathrm{E}-03$ & 0.3572 & 163.1 & 30.4 & 0.3296 & 8.4 & 57.0 & 0.3132 & 260.0 & 11.6 & 1.14 & -0.23 \\
\hline $15 \mathrm{R}-1,3$ & 63.83 & Olivine gabbro & $1.29 \mathrm{E}-02$ & 0.3541 & 266.3 & 15.7 & 0.3314 & 9.4 & 38.9 & 0.3145 & 158.8 & 46.9 & 1.13 & -0.12 \\
\hline $16 \mathrm{R}-1,46$ & 68.46 & Troctolite & $3.36 \mathrm{E}-02$ & 0.3614 & 355.5 & 17.9 & 0.3375 & 113.8 & 55.8 & 0.3010 & 255.6 & 28.1 & 1.20 & 0.25 \\
\hline 18R-1, 41 & 77.71 & Troctolite & $2.13 \mathrm{E}-02$ & 0.3466 & 308.6 & 39.9 & 0.3346 & 208.9 & 11.4 & 0.3188 & 106.0 & 47.8 & 1.09 & 0.16 \\
\hline 20R-1, 68 & 82.98 & Troctolite & $4.63 \mathrm{E}-02$ & 0.3457 & 316.9 & 49.0 & 0.3376 & 210.4 & 13.8 & 0.3167 & 109.5 & 37.6 & 1.09 & 0.46 \\
\hline 20R-2, 58 & 84.26 & Troctolite & $1.90 \mathrm{E}-02$ & 0.3401 & 252.5 & 21.7 & 0.3337 & 141.0 & 42.7 & 0.3262 & 1.6 & 39.4 & 1.04 & 0.09 \\
\hline 22R-1, 117 & 90.57 & Troctolite & $4.01 \mathrm{E}-02$ & 0.3547 & 180.2 & 45.2 & 0.3290 & 59.2 & 27.1 & 0.3163 & 310.2 & 32.5 & 1.12 & -0.32 \\
\hline $22 \mathrm{R}-2,32$ & 91.12 & Troctolite & $3.26 \mathrm{E}-02$ & 0.3545 & 60.0 & 45.6 & 0.3357 & 300.1 & 25.9 & 0.3098 & 191.7 & 33.1 & 1.15 & 0.19 \\
\hline 22R-3, 17 & 92.30 & Troctolite & 4.40E-02 & 0.3428 & 299.7 & 61.0 & 0.3357 & 142.2 & 27.1 & 0.3215 & 47.3 & 9.5 & 1.07 & 0.34 \\
\hline $23 \mathrm{R}-1,68$ & 99.48 & Troctolite & 3.17E-02 & 0.3494 & 180.6 & 20.9 & 0.3320 & 308.1 & 57.9 & 0.3186 & 81.2 & 23.2 & 1.10 & -0.11 \\
\hline $23 R-2,56$ & 100.77 & Troctolite & $3.25 \mathrm{E}-02$ & 0.3478 & 24.7 & 40.0 & 0.3372 & 136.7 & 24.1 & 0.3150 & 249.1 & 40.4 & 1.11 & 0.37 \\
\hline $23 \mathrm{R}-2,59$ & 100.80 & Troctolite & $3.55 \mathrm{E}-02$ & 0.3523 & 23.0 & 44.4 & 0.3343 & 131.9 & 18.3 & 0.3134 & 238.0 & 40.0 & 1.12 & 0.11 \\
\hline
\end{tabular}


Table T11. $P$-wave velocity, density, and porosity measurements, Hole U1415J.

\begin{tabular}{|c|c|c|c|c|c|c|c|c|c|c|c|c|c|c|c|c|c|}
\hline \multirow{3}{*}{$\begin{array}{l}\text { Core, section, } \\
\text { interval (cm) }\end{array}$} & \multirow{3}{*}{$\begin{array}{l}\text { Depth } \\
\text { (mbsf) }\end{array}$} & \multicolumn{11}{|c|}{$P$-wave velocity } & \multirow{3}{*}{$\begin{array}{l}\text { Bulk } \\
\text { density } \\
\left(\mathrm{g} / \mathrm{cm}^{3}\right)\end{array}$} & \multirow{3}{*}{$\begin{array}{l}\text { Grain } \\
\text { density } \\
\left(\mathrm{g} / \mathrm{cm}^{3}\right)\end{array}$} & \multirow{3}{*}{$\begin{array}{l}\text { Porosity } \\
\text { (vol\%) }\end{array}$} & \multirow[b]{3}{*}{ Primary lithology } & \multirow{3}{*}{$\begin{array}{c}\text { Background } \\
\text { alteration } \\
\text { (\%) }\end{array}$} \\
\hline & & \multicolumn{3}{|c|}{ Mean $(\mathrm{km} / \mathrm{s})$} & \multicolumn{3}{|c|}{ Standard deviation $(\mathrm{km} / \mathrm{s})$} & \multicolumn{3}{|c|}{$\underline{\text { Standard deviation (\%) }}$} & \multirow{2}{*}{$\begin{array}{l}\text { Mean } \\
(\mathrm{km} / \mathrm{s})\end{array}$} & \multirow{2}{*}{$\begin{array}{l}\text { Apparent } \\
\text { anisotropy } \\
(\%)\end{array}$} & & & & & \\
\hline & & $x$ & $y$ & $z$ & $x$ & $y$ & $z$ & $x$ & $y$ & $z$ & & & & & & & \\
\hline \multicolumn{18}{|l|}{ 345-U1415P- } \\
\hline $3 R-1,67-69$ & 13.17 & 6.26 & 6.45 & 6.38 & 0.0105 & 0.0008 & 0.0008 & 0.17 & 0.01 & 0.01 & 6.36 & 2.9 & 2.81 & 2.82 & 0.7 & Olivine gabbro & $10-30$ \\
\hline $3 R-1,69.5-71.5$ & 13.195 & 6.52 & 6.38 & 6.32 & 0.0086 & 0.0116 & 0.0018 & 0.13 & 0.18 & 0.03 & 6.40 & 3.0 & 2.82 & 2.83 & 0.6 & Olivine gabbro & $10-30$ \\
\hline $4 G-1,13-15$ & 12.63 & 6.36 & 6.42 & 6.51 & 0.0077 & 0.0019 & 0.0010 & 0.12 & 0.03 & 0.02 & 6.43 & 2.2 & 2.94 & 2.96 & 0.7 & Orthopyroxene-bearing olivine gabbro & $10-30$ \\
\hline 4G-1, 95-97 & 13.45 & 6.29 & 6.35 & 6.22 & 0.0020 & 0.0012 & 0.0025 & 0.03 & 0.02 & 0.04 & 6.29 & 2.0 & 2.84 & 2.85 & 0.5 & Olivine gabbro & $10-30$ \\
\hline 4G-1, 97.5-99.5 & 13.475 & 6.38 & 6.46 & 6.36 & 0.0029 & 0.0010 & 0.0050 & 0.05 & 0.02 & 0.08 & 6.40 & 1.5 & 2.85 & 2.86 & 0.4 & Olivine gabbro & $10-30$ \\
\hline $4 G-2,5-7$ & 13.96 & 6.29 & 6.33 & 6.17 & 0.0012 & 0.0014 & 0.0036 & 0.02 & 0.02 & 0.06 & 6.26 & 2.6 & 2.83 & 2.85 & 1.1 & Olivine gabbro & $10-30$ \\
\hline $5 \mathrm{R}-1,38-40$ & 18.48 & 6.38 & 6.23 & 6.02 & 0.0080 & 0.0046 & 0.0010 & 0.13 & 0.07 & 0.02 & 6.21 & 5.9 & 2.80 & 2.82 & 1.1 & Orthopyroxene-bearing olivine gabbro & $10-30$ \\
\hline $5 R-2,50-52$ & 20.02 & 6.31 & 6.33 & 6.01 & 0.0012 & 0.0032 & 0.0008 & 0.02 & 0.05 & 0.01 & 6.22 & 5.2 & 2.85 & 2.86 & 0.7 & Orthopyroxene-bearing olivine gabbro & $<10$ \\
\hline $6 \mathrm{R}-1,71-73$ & 23.31 & 6.39 & 6.39 & 6.18 & 0.0008 & 0.0008 & 0.0006 & 0.01 & 0.01 & 0.01 & 6.32 & 3.3 & 2.84 & 2.85 & 0.5 & Olivine gabbro & $30-60$ \\
\hline $6 \mathrm{R}-2,91-93$ & 24.915 & 6.16 & 6.26 & 6.02 & 0.0027 & 0.0030 & 0.0039 & 0.04 & 0.05 & 0.06 & 6.15 & 4.0 & 2.86 & 2.88 & 0.8 & Troctolitic olivine gabbro & $60-90$ \\
\hline 7R-1, 112-114 & 28.22 & 6.47 & 6.28 & 6.15 & 0.0020 & 0.0170 & 0.0072 & 0.03 & 0.27 & 0.12 & 6.30 & 5.1 & 2.96 & 2.99 & 1.6 & Orthopyroxene-bearing olivine gabbro & $30-60$ \\
\hline $7 R-2,2-4$ & 28.51 & 6.18 & 6.33 & 6.07 & 0.0009 & 0.0008 & 0.0012 & 0.01 & 0.01 & 0.02 & 6.19 & 4.2 & 2.79 & 2.81 & 1.1 & Orthopyroxene-bearing olivine gabbro & $30-60$ \\
\hline $8 R-1,4-6$ & 31.44 & 6.11 & 6.25 & 6.10 & 0.0010 & 0.0036 & 0.0018 & 0.02 & 0.06 & 0.03 & 6.15 & 2.5 & 2.81 & 2.83 & 0.9 & Olivine gabbro & $10-30$ \\
\hline $9 \mathrm{R}-1,5-7$ & 36.45 & 6.32 & 6.48 & 6.15 & 0.0010 & 0.0019 & 0.0014 & 0.02 & 0.03 & 0.02 & 6.32 & 5.3 & 2.83 & 2.85 & 0.8 & Olivine gabbro & $10-30$ \\
\hline $9 \mathrm{R}-2,21-23$ & 38.025 & 6.39 & 6.53 & 6.42 & 0.0018 & 0.0020 & 0.0052 & 0.03 & 0.03 & 0.08 & 6.45 & 2.2 & 2.85 & 2.86 & 0.5 & Orthopyroxene-bearing olivine gabbro & $30-60$ \\
\hline 10R-1, 138-140 & 42.38 & 6.12 & 6.12 & 6.18 & 0.0023 & 0.0036 & 0.0042 & 0.04 & 0.06 & 0.07 & 6.14 & 1.0 & 2.82 & 2.84 & 1.2 & Orthopyroxene-bearing olivine gabbro & $60-90$ \\
\hline $10 \mathrm{R}-2,1-3$ & 42.44 & 5.99 & 6.23 & 6.10 & 0.0005 & 0.0036 & 0.0012 & 0.01 & 0.06 & 0.02 & 6.11 & 3.9 & 2.76 & 2.78 & 1.2 & Orthopyroxene-bearing olivine gabbro & $10-30$ \\
\hline $11 \mathrm{R}-1,44-46$ & 46.04 & 6.11 & 6.27 & 6.35 & 0.0042 & 0.0069 & 0.0074 & 0.07 & 0.11 & 0.12 & 6.25 & 3.9 & 2.86 & 2.86 & 0.4 & Orthopyroxene-bearing olivine gabbro & $30-60$ \\
\hline $12 \mathrm{R}-1,6-8$ & 49.76 & 6.41 & 6.49 & 6.42 & 0.0008 & 0.0029 & 0.0059 & 0.01 & 0.04 & 0.09 & 6.44 & 1.2 & 2.88 & 2.89 & 0.5 & Orthopyroxene-bearing olivine gabbro & $10-30$ \\
\hline 13R-1, 16-18 & 54.86 & 6.34 & 6.33 & 6.49 & 0.0005 & 0.0031 & 0.0021 & 0.01 & 0.05 & 0.03 & 6.39 & 2.7 & 2.87 & 2.88 & 0.4 & Olivine gabbro & $10-30$ \\
\hline $13 R-1,116-118$ & 55.86 & 6.27 & 6.18 & 6.09 & 0.0012 & 0.0019 & 0.0029 & 0.02 & 0.03 & 0.05 & 6.18 & 2.9 & 2.85 & 2.86 & 0.8 & Olivine gabbro & $10-30$ \\
\hline $14 \mathrm{R}-1,36-38$ & 59.16 & 6.33 & 6.24 & 6.30 & 0.0024 & 0.0036 & 0.0028 & 0.04 & 0.06 & 0.04 & 6.29 & 1.4 & 2.90 & 2.91 & 0.4 & Olivine gabbro & $10-30$ \\
\hline $14 \mathrm{R}-2,20-22$ & 60.29 & 6.23 & 6.34 & 6.16 & 0.0008 & 0.0010 & 0.0008 & 0.01 & 0.02 & 0.01 & 6.25 & 2.9 & 2.79 & 2.82 & 1.4 & Olivine gabbro & $30-60$ \\
\hline $15 \mathrm{R}-1,2-4$ & 63.82 & 6.36 & 6.40 & 6.38 & 0.0008 & 0.0063 & 0.0093 & 0.01 & 0.10 & 0.15 & 6.38 & 0.7 & 2.82 & 2.82 & 0.4 & Olivine gabbro & $10-30$ \\
\hline $16 \mathrm{R}-1,45-47$ & 68.45 & 6.12 & 5.98 & 6.13 & 0.0041 & 0.0016 & 0.0015 & 0.07 & 0.03 & 0.02 & 6.08 & 2.5 & 2.79 & 2.81 & 0.9 & Troctolite & $30-60$ \\
\hline $18 \mathrm{R}-1,40-42$ & 77.7 & 6.07 & 6.17 & 6.10 & 0.0095 & 0.0062 & 0.0045 & 0.16 & 0.10 & 0.07 & 6.11 & 1.6 & 2.76 & 2.78 & 1.3 & Troctolite & $30-60$ \\
\hline 20R-1, 67-69 & 82.97 & 6.05 & 5.89 & 6.00 & 0.0014 & 0.0025 & 0.0054 & 0.02 & 0.04 & 0.09 & 5.98 & 2.7 & 2.71 & 2.74 & 1.4 & Troctolite & $30-60$ \\
\hline $20 \mathrm{R}-2,57-59$ & 84.25 & 6.03 & 6.07 & 6.26 & 0.0011 & 0.0018 & 0.0092 & 0.02 & 0.03 & 0.15 & 6.12 & 3.7 & 2.71 & 2.74 & 1.8 & Troctolite & $30-60$ \\
\hline \multirow[t]{5}{*}{$23 R-2,58-60$} & 100.79 & 5.96 & 6.11 & 6.04 & 0.0082 & 0.0008 & 0.0033 & 0.14 & 0.01 & 0.05 & 6.03 & 2.5 & 2.72 & 2.75 & 1.2 & Troctolite & $30-60$ \\
\hline & & & & & & & & \multirow{2}{*}{\multicolumn{3}{|c|}{$\begin{array}{r}\text { Mean: } \\
\text { Standard deviation: }\end{array}$}} & 6.25 & 2.95 & 2.82 & 2.84 & 0.87 & & \\
\hline & & & & & & & & & & & 0.13 & 1.33 & 0.06 & 0.06 & 0.40 & & \\
\hline & & & & & & & & \multirow{2}{*}{\multicolumn{3}{|c|}{ Maximum: }} & 6.45 & 5.87 & 2.96 & 2.99 & 1.80 & & \\
\hline & & & & & & & & & & & 5.98 & 0.68 & 2.71 & 2.74 & 0.40 & & \\
\hline
\end{tabular}


Table T12. Summary of discrete sample physical property measurements, Site U1415.

\begin{tabular}{|c|c|c|c|c|c|c|c|c|c|c|}
\hline \multirow[b]{3}{*}{ Measurement } & \multicolumn{6}{|c|}{ All Site U1415 samples } & \multicolumn{4}{|c|}{ Hole U1415I } \\
\hline & \multicolumn{2}{|c|}{$\begin{array}{l}\text { Gabbro and } \\
\text { gabbronorite }\end{array}$} & \multicolumn{2}{|c|}{ Olivine gabbro } & \multicolumn{2}{|c|}{ Troctolite } & \multicolumn{2}{|c|}{$\begin{array}{l}\text { Gabbro and } \\
\text { gabbronorite }\end{array}$} & \multicolumn{2}{|c|}{ Olivine gabbro } \\
\hline & Mean & $\begin{array}{l}\text { Standard } \\
\text { deviation }\end{array}$ & Mean & $\begin{array}{l}\text { Standard } \\
\text { deviation }\end{array}$ & Mean & $\begin{array}{l}\text { Standard } \\
\text { deviation }\end{array}$ & Mean & $\begin{array}{l}\text { Standard } \\
\text { deviation }\end{array}$ & Mean & $\begin{array}{l}\text { Standard } \\
\text { deviation }\end{array}$ \\
\hline Bulk Density $\left(\mathrm{g} / \mathrm{cm}^{3}\right)$ : & 2.90 & 0.03 & 2.83 & 0.06 & 2.77 & 0.06 & 2.91 & 0.01 & 2.81 & - \\
\hline Grain Density $\left(\mathrm{g} / \mathrm{cm}^{3}\right)$ : & 2.92 & 0.04 & 2.85 & 0.05 & 2.79 & 0.06 & 2.93 & 0.00 & 2.83 & - \\
\hline Porosity (\%): & 1.1 & 0.6 & 1.3 & 1.1 & 1.2 & 0.8 & 0.9 & 0.2 & 1.4 & - \\
\hline$V_{\mathrm{P}}(\mathrm{km} / \mathrm{s}):$ & 6.31 & 0.21 & 6.16 & 0.29 & 6.14 & 0.27 & 6.28 & 0.20 & 6.26 & - \\
\hline$V_{\mathrm{P}}$ apparent anisotropy (\%): & 2.9 & 1.2 & 3.0 & 1.3 & 2.6 & 1.4 & 3.2 & 1.6 & 2.0 & - \\
\hline Thermal conductivity $(\mathrm{W} /[\mathrm{m} \cdot \mathrm{K}])$ : & 2.40 & 0.21 & 2.30 & 0.15 & 2.91 & 0.57 & 2.51 & - & 2.33 & 0.24 \\
\hline
\end{tabular}

\begin{tabular}{|c|c|c|c|c|c|c|c|c|c|c|}
\hline \multirow[b]{3}{*}{ Measurement } & \multicolumn{6}{|c|}{ Hole U1415] } & \multicolumn{4}{|c|}{ Hole U1415P } \\
\hline & \multicolumn{2}{|c|}{$\begin{array}{l}\text { Gabbro and } \\
\text { gabbronorite }\end{array}$} & \multicolumn{2}{|c|}{ Olivine gabbro } & \multicolumn{2}{|c|}{ Troctolite } & \multicolumn{2}{|c|}{ Olivine gabbro } & \multicolumn{2}{|c|}{ Troctolite } \\
\hline & Mean & $\begin{array}{l}\text { Standard } \\
\text { deviation }\end{array}$ & Mean & $\begin{array}{l}\text { Standard } \\
\text { deviation }\end{array}$ & Mean & $\begin{array}{l}\text { Standard } \\
\text { deviation }\end{array}$ & Mean & $\begin{array}{l}\text { Standard } \\
\text { deviation }\end{array}$ & Mean & $\begin{array}{l}\text { Standard } \\
\text { deviation }\end{array}$ \\
\hline Bulk Density $\left(\mathrm{g} / \mathrm{cm}^{3}\right)$ : & 2.90 & 0.03 & 2.76 & 0.04 & 2.79 & 0.07 & 2.84 & 0.05 & 2.74 & 0.03 \\
\hline Grain Density $\left(\mathrm{g} / \mathrm{cm}^{3}\right)$ : & 2.92 & 0.04 & 2.82 & 0.04 & 2.81 & 0.06 & 2.86 & 0.05 & 2.76 & 0.03 \\
\hline Porosity (\%): & 1.2 & 0.6 & 3.4 & 0.3 & 1.2 & 1.0 & 0.8 & 0.4 & 1.3 & 0.3 \\
\hline$V_{\mathrm{P}}(\mathrm{km} / \mathrm{s}):$ & 6.32 & 0.23 & 5.66 & 0.30 & 6.19 & 0.34 & 6.29 & 0.10 & 6.07 & 0.06 \\
\hline$V_{\mathrm{P}}$ apparent anisotropy (\%): & 2.9 & 1.1 & 3.1 & 1.1 & 2.6 & 1.7 & 3.0 & 1.4 & 2.6 & 0.7 \\
\hline Thermal conductivity $(\mathrm{W} /[\mathrm{m} \cdot \mathrm{K}])$ : & 2.37 & 0.23 & 2.20 & 0.11 & 2.97 & 0.82 & 2.31 & 0.15 & 2.87 & 0.30 \\
\hline
\end{tabular}


Table T13. Thermal conductivity measurements, Hole U1415J.

\begin{tabular}{|c|c|c|c|c|c|c|c|}
\hline Core, section & $\begin{array}{l}\text { Depth } \\
\text { (mbsf) }\end{array}$ & $\begin{array}{l}\text { Number of } \\
\text { measurements }\end{array}$ & $\begin{array}{c}\text { Thermal } \\
\text { conductivity } \\
(\mathrm{W} /[\mathrm{m} \cdot \mathrm{K}])\end{array}$ & $\begin{array}{c}\text { Standard } \\
\text { deviation } \\
(\mathrm{W} /[\mathrm{m} \cdot \mathrm{K}])\end{array}$ & $\begin{array}{c}\text { Standard } \\
\text { deviation } \\
(\%)\end{array}$ & Lithology & Comment \\
\hline \multicolumn{8}{|l|}{ 345-U1415P- } \\
\hline 4G-1A (Piece 9) & 13.52 & 8 & 2.326 & 0.037 & 1.59 & Olivine gabbro & Large probe \\
\hline 4G-2A (Piece 3) & 14.20 & 9 & 2.304 & 0.019 & 0.84 & Olivine gabbro & Large probe \\
\hline 5R-1A (Piece 6A) & 18.59 & 10 & 2.150 & 0.006 & 0.30 & Orthopyroxene-bearing olivine gabbro & Large probe \\
\hline 5R-2A (Piece 6) & 20.09 & 10 & 2.409 & 0.011 & 0.46 & Orthopyroxene-bearing olivine gabbro & Large probe \\
\hline 6R-2A (Piece 11) & 24.955 & 10 & 2.643 & 0.020 & 0.76 & Troctolitic olivine gabbro & Large probe \\
\hline 7R-1A (Piece 8B) & 27.84 & 10 & 2.141 & 0.010 & 0.49 & Orthopyroxene-bearing olivine gabbro & Large probe \\
\hline 8R-1A (Piece 5) & 32.12 & 9 & 2.298 & 0.010 & 0.45 & Orthopyroxene-bearing olivine gabbro & Large probe \\
\hline 9R-1A (Piece 10) & 37.75 & 10 & 2.274 & 0.013 & 0.57 & Orthopyroxene-bearing olivine gabbro & Large probe \\
\hline 10R-1A (Piece 8) & 42.30 & 10 & 2.336 & 0.007 & 0.30 & Olivine gabbro & Large probe \\
\hline 11R-1A (Piece 7) & 46.14 & 10 & 2.556 & 0.012 & 0.47 & Orthopyroxene-bearing olivine gabbro & Large probe \\
\hline 12R-1A (Piece 13) & 50.24 & 10 & 2.324 & 0.012 & 0.51 & Orthopyroxene-bearing olivine gabbro & Large probe \\
\hline 13R-1A (Piece 6) & 55.22 & 10 & 2.242 & 0.016 & 0.72 & Olivine gabbro & Large probe \\
\hline 13R-2A (Piece 9) & 56.895 & 9 & 2.196 & 0.012 & 0.54 & Olivine gabbro & Large probe \\
\hline 14R-2A (Piece 1B) & 60.20 & 10 & 2.096 & 0.009 & 0.45 & Olivine gabbro & Large probe \\
\hline 16R-1A (Piece 3) & 68.23 & 10 & 2.794 & 0.018 & 0.64 & Troctolite & Large probe \\
\hline 18R-1A (Piece 8) & 78.19 & 10 & 2.295 & 0.018 & 0.79 & Troctolite & Large probe \\
\hline 20R-1A (Piece 8) & 83.22 & 10 & 3.126 & 0.022 & 0.70 & Troctolite & Large probe \\
\hline 20R-2A (Piece 9) & 84.66 & 8 & 2.886 & 0.040 & 1.38 & Troctolite & Large probe \\
\hline 22R-1A (Piece 11) & 90.48 & 10 & 3.044 & 0.040 & 1.30 & Troctolite & Large probe \\
\hline \multirow[t]{5}{*}{ 22R-3A (Piece 2) } & 92.35 & 10 & 3.051 & 0.013 & 0.44 & Troctolite & Large probe \\
\hline & & Mean: & 2.475 & 0.017 & 0.68 & & \\
\hline & & andard deviation: & 0.331 & 0.010 & 0.36 & & \\
\hline & & Maximum: & 3.126 & 0.040 & 1.59 & & \\
\hline & & Minimum: & 2.096 & 0.006 & 0.30 & & \\
\hline
\end{tabular}

